Supporting Information

\title{
Room Temperature Acceptorless Alkane Dehydrogenation from Molecular $\sigma$-Alkane Complexes
}

\footnotetext{
Alasdair I. McKay, ${ }^{1}$ Alexander J. Bukvic, ${ }^{1}$ Bengt E. Tegner, ${ }^{2}$ Arron L. Burnage, ${ }^{2}$ Antonio J. Martinez-Martinez, ${ }^{1}$ Nicholas H. Rees, ${ }^{1}$ Stuart A. Macgregor, ${ }^{2 \star}$ Andrew S. Weller. $^{1 *}$

${ }^{1}$ Department of Chemistry, Chemistry Research Laboratories, University of Oxford, OX1 3TA, U.K. Email: andrew.weller@chem.ox.ac.uk

${ }^{2}$ Institute of Chemical Sciences, Heriot-Watt University, Edinburgh, EH14 4AS, UK. Email: S.A.Macgregor@hw.ac.uk
} 


\section{TABLE OF CONTENTS}

S.1. EXPERIMENTAL DETAILS

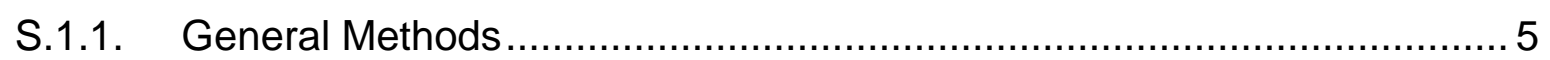

S.2. SYNTHETIC PROCEDURES

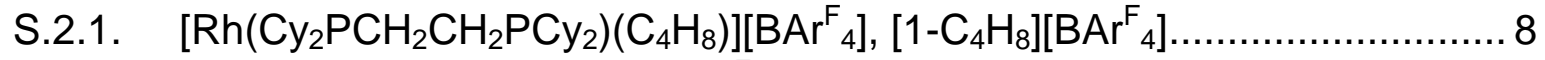

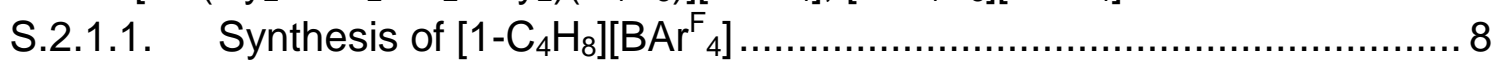

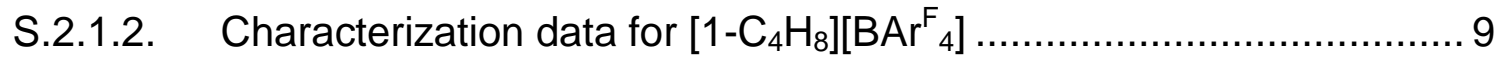

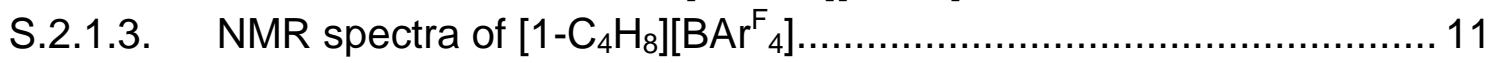

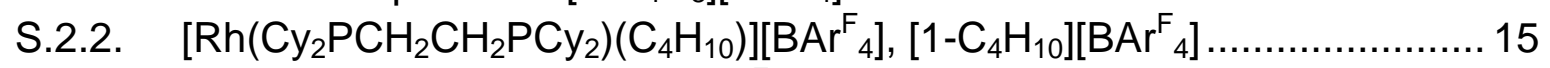

S.2.2.1. Synthesis of $\left[1-\mathrm{C}_{4} \mathrm{H}_{10}\right]\left[\mathrm{BAr}_{4}\right]$ for an $\mathrm{x}$-ray diffraction study .............15

S.2.2.2. Synthesis of $\left[1-\mathrm{C}_{4} \mathrm{H}_{10}\right]\left[\mathrm{BAr}_{4}{ }_{4}\right]$ for SSNMR characterization ............. 15

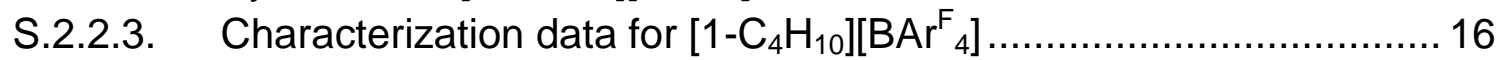

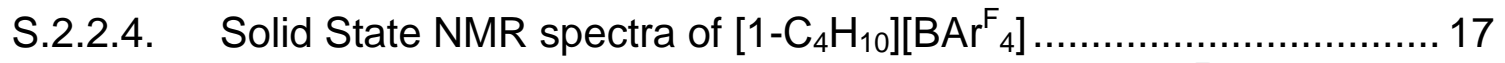

S.2.2.5. Liberation of the bound isobutane from $\left[1-\mathrm{C}_{4} \mathrm{H}_{10}\right]\left[\mathrm{BAr} \mathrm{F}_{4}\right] \ldots \ldots \ldots \ldots \ldots . .20$

S.2.2.6. Solid state decomposition products of $\left[1-\mathrm{C}_{4} \mathrm{H}_{10}\right]\left[\mathrm{BAr}_{4}\right]$ under $\mathrm{H}_{2} \ldots .21$

S.2.3. $\left[\mathrm{Rh}\left(\mathrm{Cy}_{2} \mathrm{PCH}_{2} \mathrm{CH}_{2} \mathrm{PCy}\right)\left(\mathrm{C}_{6} \mathrm{H}_{8}\right)\right]\left[\mathrm{BAr}_{4}\right],\left[1-\mathrm{C}_{6} \mathrm{H}_{8}\right]\left[\mathrm{BAr}_{4}\right] \ldots \ldots \ldots \ldots \ldots \ldots \ldots . .22$

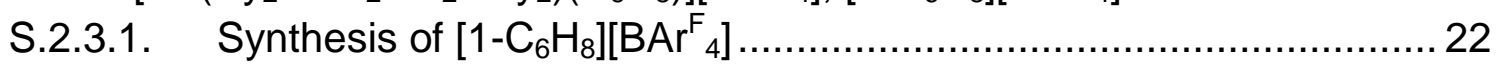

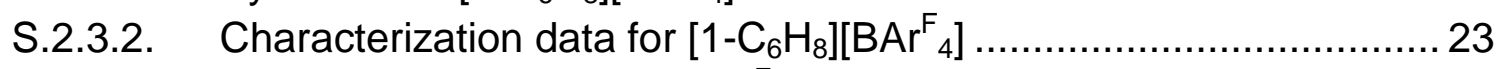

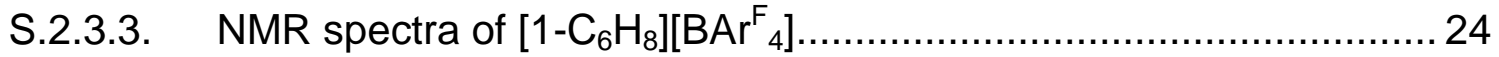

S.2.4. $\left[\mathrm{Rh}\left(\mathrm{Cy}_{2} \mathrm{PCH}_{2} \mathrm{CH}_{2} \mathrm{PCy}\right)\left(\mathrm{C}_{6} \mathrm{H}_{12}\right)\right]\left[\mathrm{BAr}_{4}\right],\left[1-\mathrm{C}_{6} \mathrm{H}_{12}\right]\left[\mathrm{BAr}_{4}\right] \ldots \ldots \ldots \ldots \ldots \ldots . .28$

S.2.4.1. Synthesis of $\left[1-\mathrm{C}_{6} \mathrm{H}_{12}\right]\left[\mathrm{BAr}_{4}\right]$ for an $\mathrm{x}$-ray diffraction study.............28

S.2.4.2. Synthesis of $\left[1-\mathrm{C}_{6} \mathrm{H}_{12}\right]\left[\mathrm{BAr}_{4}{ }_{4}\right]$ for SSNMR characterization .............29

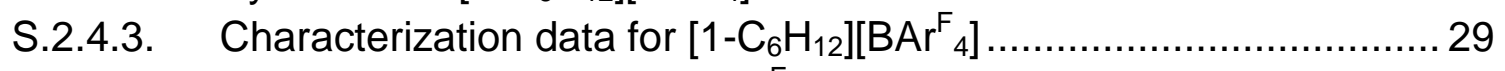

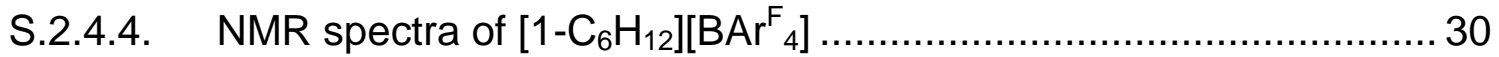

S.2.4.5. Liberation of the bound cyclohexane from $\left[1-\mathrm{C}_{6} \mathrm{H}_{12}\right]\left[\mathrm{BAr}_{4}\right] \ldots \ldots \ldots . .37$

S.2.4.6. Solid state decomposition products of $\left[1-\mathrm{C}_{6} \mathrm{H}_{12}\right]\left[\mathrm{BAr}_{4}\right]$ under $\mathrm{H}_{2} \ldots 38$

S.2.5. $\left[\mathrm{Rh}\left(\mathrm{Cy}_{2} \mathrm{PCH}_{2} \mathrm{CH}_{2} \mathrm{PCy}_{2}\right)\left(\mathrm{C}_{6} \mathrm{H}_{6}\right)\right]\left[\mathrm{BAr}_{4}\right],\left[1-\mathrm{C}_{6} \mathrm{H}_{6}\right]\left[\mathrm{BAr}_{4}\right] \ldots \ldots \ldots \ldots \ldots \ldots \ldots . . . . . . . . . . . .39$

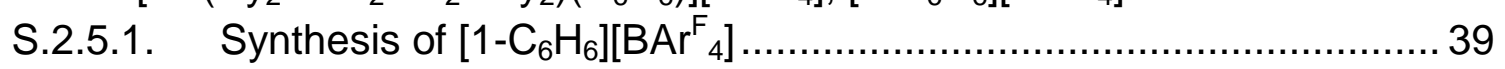

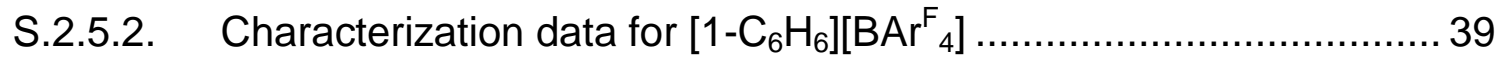

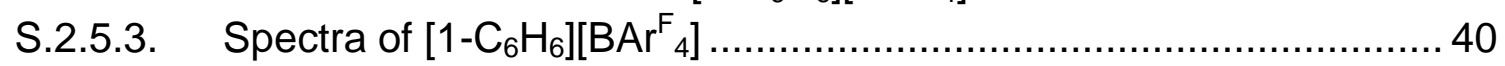

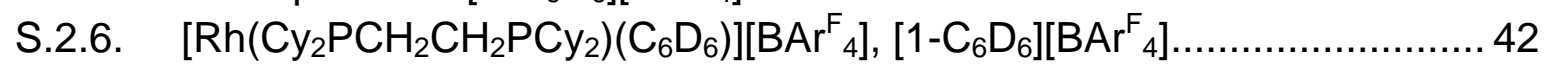

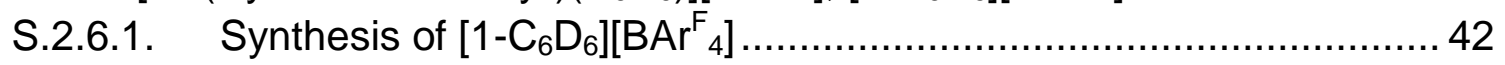

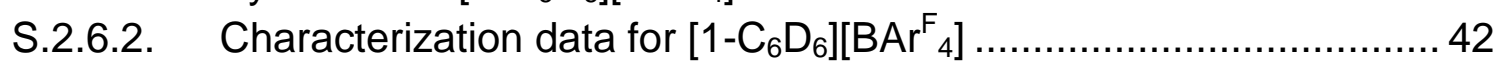

S.3. H/D EXCHANGE EXPERIMENTS …................................................... 43

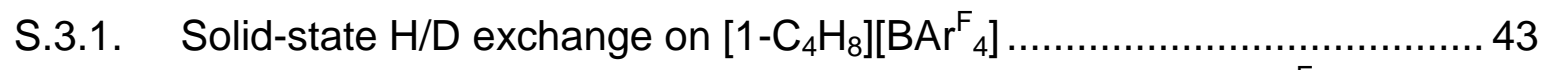

S.3.1.1. General Experimental of $\mathrm{H} / \mathrm{D}$ Exchange on $\left[1-\mathrm{C}_{4} \mathrm{H}_{8}\right]\left[\mathrm{BAr}_{4}\right] \ldots \ldots \ldots . . .43$

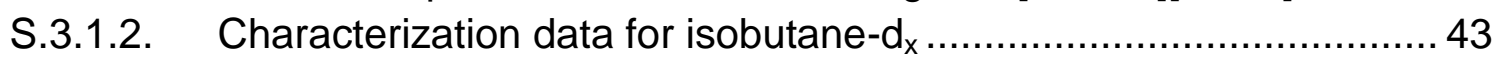

S.3.1.3. GC EI-MS Spectra of isobutane- $d_{x}(x=10-7)$ and isobutane- $h_{10 . .} 46$

S.3.1.4. Simulated solution ${ }^{13} \mathrm{C}\left\{{ }^{1} \mathrm{H}\right\}$ NMR spectra of isobutane- $\mathrm{d}_{\mathrm{x}}(\mathrm{x}=10-7)$.

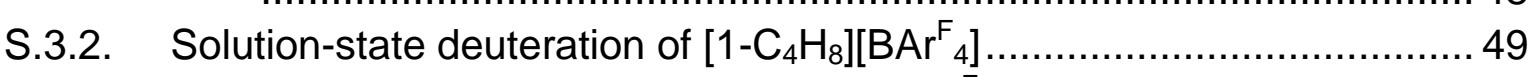

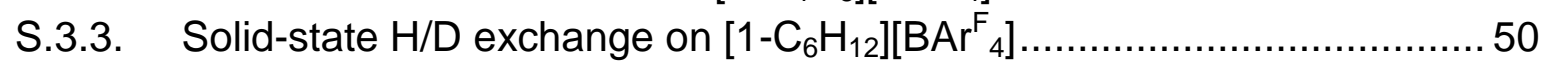


S.3.3.1. General Experimental of $H / D$ Exchange on $\left[1-\mathrm{C}_{6} \mathrm{H}_{12}\right]\left[B A \mathrm{r}^{\mathrm{F}}\right] \ldots \ldots \ldots . .50$

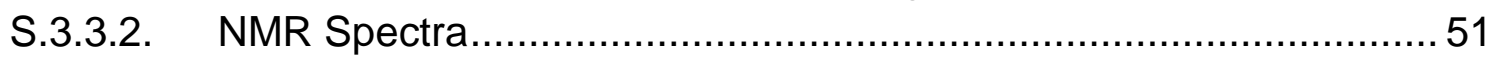

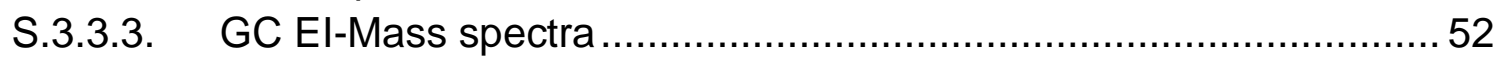

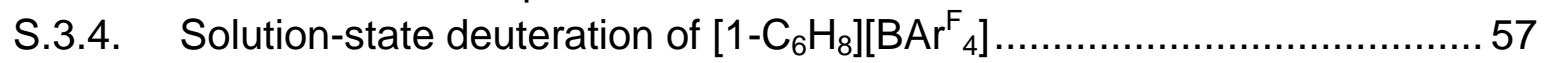

S.3.4.1. Procedure for the solution-state deuteration of $\left[1-\mathrm{C}_{6} \mathrm{H}_{8}\right]\left[\mathrm{BAr}^{\mathrm{F}}\right] \ldots \ldots .57$

S.3.4.2. GC El-Mass Spectra ........................................................... 58

S.4. ALKANE DEHYDROGENATION EXPERIMENTS ..................................59

S.4.1. Dehydrogenation of $\left[1-\mathrm{C}_{4} \mathrm{H}_{10}\right]\left[\mathrm{BAr}_{4}\right]$ to form $\left[1-\mathrm{C}_{4} \mathrm{H}_{8}\right]\left[\mathrm{BAr}{ }_{4}\right] \ldots \ldots \ldots \ldots . . . . .59$

S.4.1.1. Solid-state dehydrogenation of $\left[1-\mathrm{C}_{4} \mathrm{H}_{10}\right]\left[\mathrm{BAr}_{4}{ }_{4}\right]$ under argon flow to

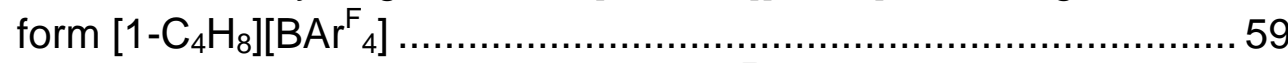

S.4.1.2. Kinetics of the solid-state $\left[1-\mathrm{C}_{4} \mathrm{H}_{10}\right]\left[\mathrm{BAr}_{4}\right]$ dehydrogenation under

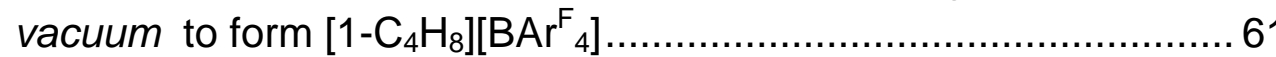

S.4.1.3. Single-Crystal to Single-Crystal dehydrogenation of $\left[1-\mathrm{C}_{4} \mathrm{H}_{10}\right]\left[\mathrm{BAr}{ }_{4}\right]$ under vacuum to form $\left[1-\mathrm{C}_{4} \mathrm{H}_{8}\right]\left[\mathrm{BAr}_{4}{ }_{4}\right]$ for an $\mathrm{x}$-ray diffraction study...

S.4.2. Dedeuteration of $\left[1-C_{4} D_{x}\right.$-alkane] $\left[B \mathrm{Br}_{4}{ }_{4}\right]$ under vacuum to form $\left[1-C_{4} D_{x^{-}}\right.$ alkene] $\left[\mathrm{BAr}_{4}{ }_{4}\right]$ 65

S.4.2.1. Solid state dedeuteration of $\left[1-\mathrm{C}_{4} \mathrm{D}_{\mathrm{x}}\right.$-alkane] $\left.] \mathrm{BAr}_{4}\right]$ under vacuum to form [1-C $\mathrm{C}_{4} \mathrm{D}_{\mathrm{x}}$-alkene][BAr$\left.{ }_{4}\right]$ 65

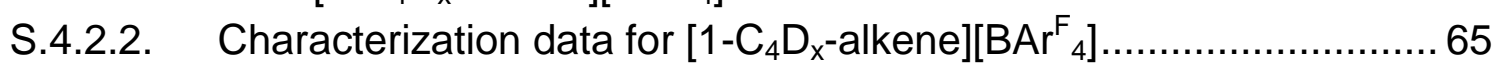

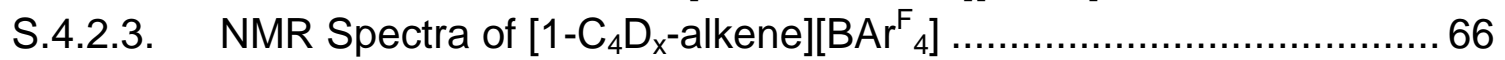

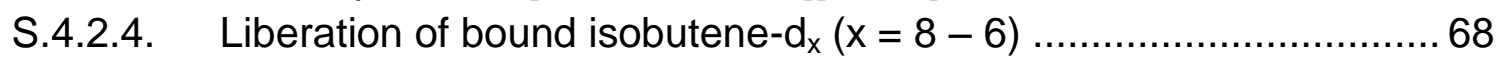

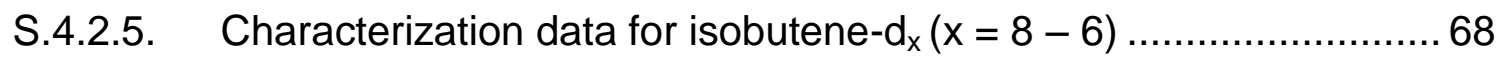

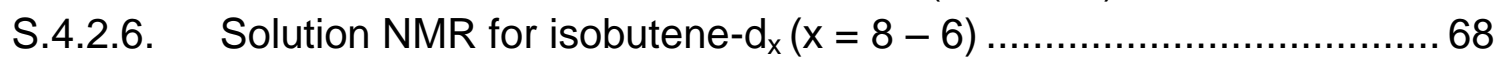

S.4.2.7. GC EI-MS Mass Spectra of isobutene- $d_{x}(x=8-6) \ldots \ldots \ldots \ldots \ldots \ldots \ldots . . .70$

S.4.2.8. Simulated solution ${ }^{13} \mathrm{C}\left\{{ }^{1} \mathrm{H}\right\}$ NMR spectra of isobutene- $\mathrm{d}_{\mathrm{x}}(\mathrm{x}=8-6) 71$

S.4.3. Solid-state dehydrogenation of $\left[1-\mathrm{C}_{6} \mathrm{H}_{12}\right]\left[\mathrm{BAr}_{4}\right]$ to form $\left[1-\mathrm{C}_{6} \mathrm{H}_{8}\right]\left[\mathrm{BAr}_{4}\right] 75$

S.4.3.1. Solid-state dehydrogenation of $\left[1-\mathrm{C}_{6} \mathrm{H}_{12}\right]\left[\mathrm{BAr}_{4}\right]$ under argon flow to

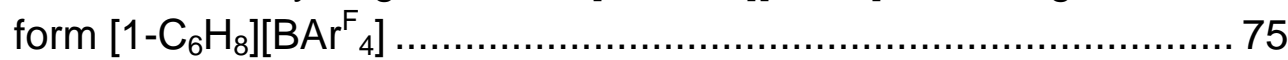

S.4.3.2. Solid-state dehydrogenation of $\left[1-\mathrm{C}_{6} \mathrm{H}_{12}\right]\left[\mathrm{BAr}_{4}{ }_{4}\right]$ under vacuum to

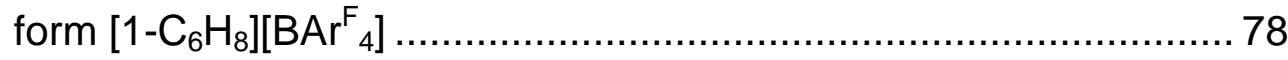

S.4.3.3. Kinetics of the solid-state $\left[1-\mathrm{C}_{6} \mathrm{H}_{12}\right]\left[\mathrm{BAr}_{4}\right]$ dehydrogenation under

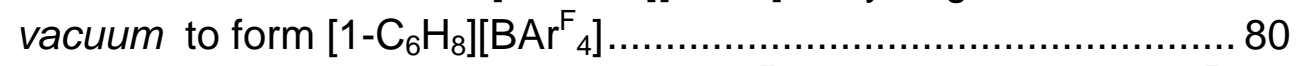

S.4.4. Solid-state dehydrogenation of $\left[1-\mathrm{C}_{6} \mathrm{H}_{12}\right]\left[\mathrm{BAr}_{4}\right]$ to form $\left[1-\mathrm{C}_{6} \mathrm{H}_{10}\right]\left[\mathrm{BAr}_{4}{ }_{4}\right] \ldots$

S.4.4.1. Solid-State Synthesis of $\left[1-\mathrm{C}_{6} \mathrm{H}_{10}\right]\left[\mathrm{BAr}^{\mathrm{F}}\right] \ldots \ldots \ldots \ldots \ldots \ldots \ldots \ldots \ldots \ldots . . . . \ldots 3$

S.4.4.2. Isolation and solution-state characterization data for $\left[1-\mathrm{C}_{6} \mathrm{H}_{10}\right]\left[\mathrm{BAr}_{4}{ }_{4}\right]$

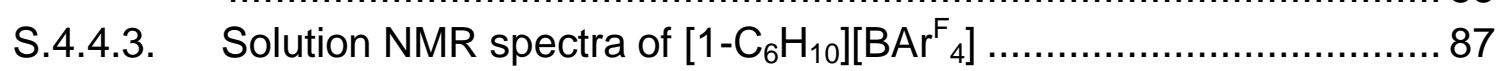

S.4.4.4. Liberation of the bound cyclohexene from $\left[1-\mathrm{C}_{6} \mathrm{H}_{10}\right]\left[\mathrm{BAr}_{4}{ }_{4}\right] \ldots \ldots \ldots \ldots . . .90$

S.4.5. Solid state dedeuteration of $\left[1-\mathrm{C}_{6} \mathrm{D}_{12}\right]\left[\mathrm{BAr}_{4}\right]$ under vacuum to form [1$\left.\mathrm{C}_{6} \mathrm{D}_{8}\right]\left[\mathrm{BAr}_{4}{ }_{4}\right]$ 
S.4.5.1. Kinetics of the solid state dedeuteration of $\left[1-\mathrm{C}_{6} \mathrm{D}_{12}\right]\left[\mathrm{BAr}{ }_{4}{ }_{4}\right]$ under

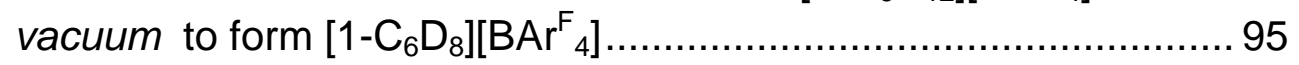

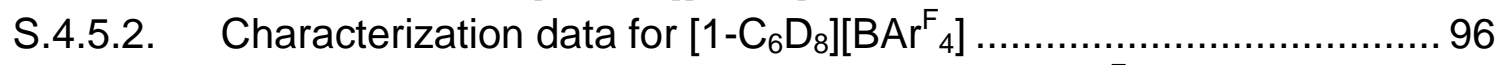

S.4.5.3. Solution NMR and mass spectra of $\left[1-\mathrm{C}_{6} \mathrm{D}_{8}\right]\left[\mathrm{BAr}_{4}{ }_{4}\right] \ldots \ldots \ldots \ldots \ldots \ldots . . . . . . . . . . . . .97$

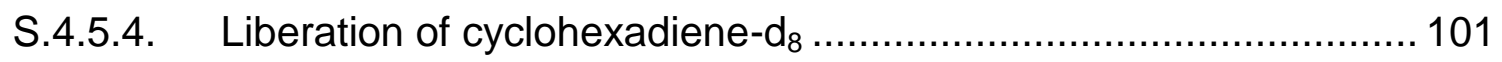

S.5. CRYSTALLOGRAPHIC AND REFINEMENT DATA ................................ 104

S.5.1. Crystal structure determinations ........................................................ 104

S.5.2. Additional comments crystal structures and refinement data .............. 104

S.5.3. Single Crystal X-ray Diffraction Images ............................................ 108

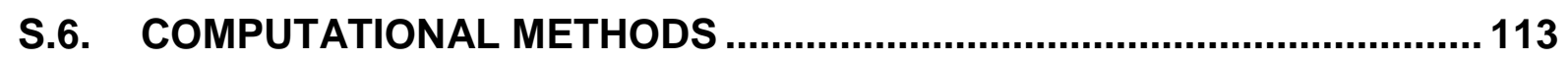

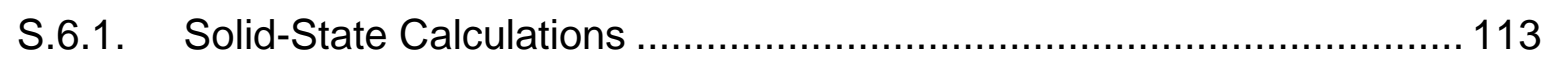

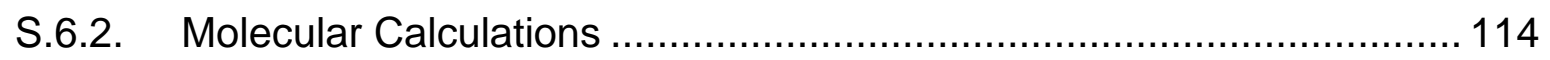

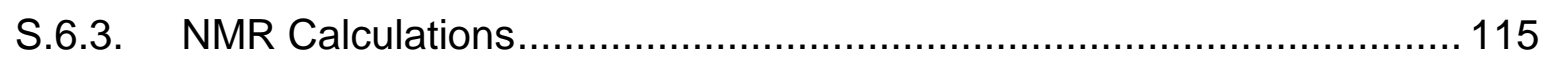

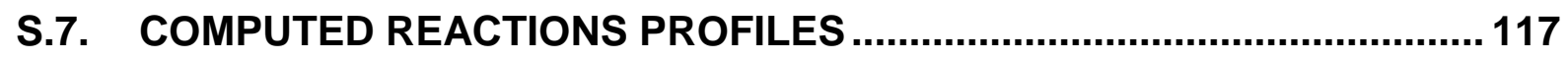

S.7.1. Dehydrogenation of the Isolated $\left[1-\mathrm{C}_{6} \mathrm{H}_{12}\right]^{+}$Cation............................. 117

S.7.2. Dehydrogenation of the Isolated $\left[1-\mathrm{C}_{6} \mathrm{H}_{10}\right]^{+}$Cation............................... 118

S.7.3. Dehydrogenation of $\left[1-\mathrm{C}_{6} \mathrm{H}_{12}\right]\left[\mathrm{BAr}_{4}{ }_{4}\right]$ in the Solid-State ...................... 120

S.7.4. Dehydrogenation of $\left[1-\mathrm{C}_{6} \mathrm{H}_{10}\right]\left[\mathrm{BAr}_{4}{ }_{4}\right]$ in the Solid-State ...................... 121

S.7.5. Cyclohexane rearrangement processes of $\left[1-\mathrm{C}_{6} \mathrm{H}_{12}\right]\left[\mathrm{BAr}_{4}\right]$ in the Solid

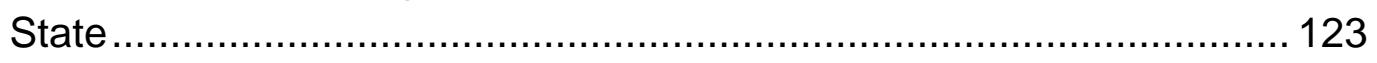

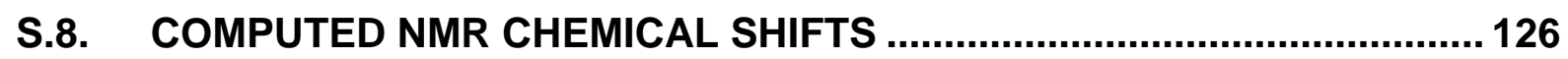

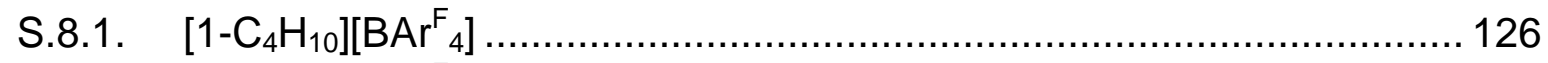

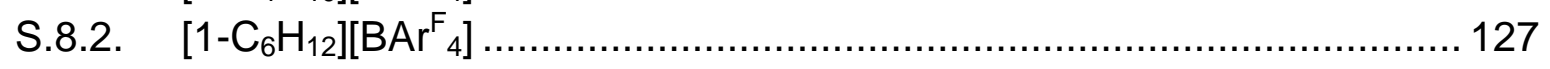

S.9. ELECTRONIC STRUCTURE ANALYSES............................................ 128

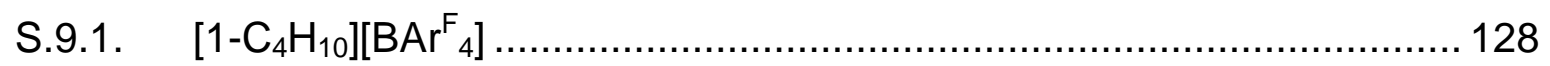

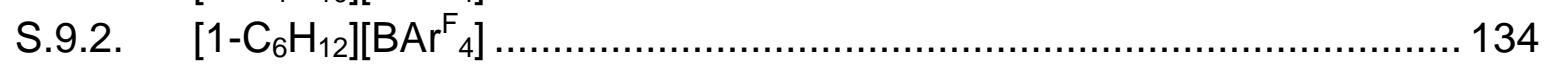

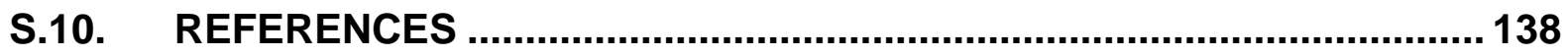




\section{S.1. Experimental details}

\section{S.1.1. General Methods}

All manipulations (unless otherwise stated) were performed under an atmosphere of argon, using standard Schlenk techniques on a dual vacuum/inlet manifold or by employment of an MBraun glovebox. Glassware was dried in an oven at $130^{\circ} \mathrm{C}$ overnight prior to use. Pentane, benzene and dichloromethane (abbreviated as $\mathrm{CH}_{2} \mathrm{Cl}_{2}$ ) were dried using an MBraun SPS-800 solvent purification system and degassed by three freeze-pump-thaw cycles. 1,2- $\mathrm{F}_{2} \mathrm{C}_{6} \mathrm{H}_{4}$ (abbreviated as $\mathrm{F}_{2} \mathrm{C}_{6} \mathrm{H}_{4}$ ) was stirred over $\mathrm{Al}_{2} \mathrm{O}_{3}$ for two hours then over $\mathrm{CaH}_{2}$ overnight before being vacuum distilled and subsequently degassed by three freeze- pump-thaw cycles. $d_{2}$ dichloromethane (abbreviated to $\mathrm{CD}_{2} \mathrm{Cl}_{2}$ ) and $d_{3}$-acetonitrile (abbreviated to $d_{3}$ $\mathrm{MeCN}$ ) was dried by stirring over $\mathrm{CaH}_{2}$ overnight before being vacuum distilled onto $3 \AA$ molecular sieves and subsequently degassed by three freeze-pump-thaw cycles. $\mathrm{d}_{6}$-Benzene (abbreviated as $\mathrm{C}_{6} \mathrm{D}_{6}$ ) was stirred over Na pieces overnight before being vacuum distilled onto $3 \AA$ molecular sieves and subsequently degassed by three freeze-pump-thaw cycles. Isobutene and Isobutane was purchased from CK Gases and used as received. All other chemicals were purchased from commercial vendors and used as received.

$\left[\mathrm{Rh}\left(\mathrm{Cy}_{2} \mathrm{PCH}_{2} \mathrm{CH}_{2} \mathrm{PCy}_{2}\right)\left(\mathrm{C}_{6} \mathrm{H}_{4} \mathrm{~F}_{2}\right)\right]\left[\mathrm{BAr}_{4}\right]^{\mathrm{S1}}$

$\left[1-\mathrm{C}_{6} \mathrm{H}_{4} \mathrm{~F}_{2}\right]\left[\mathrm{BAr}_{4}{ }_{4}\right]$, $\left[\mathrm{Rh}\left(\mathrm{Cy}_{2} \mathrm{PCH}_{2} \mathrm{CH}_{2} \mathrm{PCy}\right.\right.$ ) $\left.(\mathrm{NBD})\right]\left[\mathrm{BAr}{ }_{4}\right]^{\mathrm{S2}}$ (NBD = norbornadiene) [1-NBD][[BAr ${ }_{4}$ ] and $\left[\mathrm{Rh}\left(\mathrm{Cy}_{2} \mathrm{PCH}_{2} \mathrm{CH}_{2} \mathrm{PC} \mathrm{y}_{2}\right)(\mathrm{NBA})\right]\left[\mathrm{BAr}{ }_{4}\right]^{\mathrm{S} 2}$ (NBA = norborane) [1-NBA][BAr$\left.{ }_{4}\right]$ were prepared by the literature procedures.

Solution NMR data were collected on either a Bruker AVD $500 \mathrm{MHz}$ or a Bruker Ascend $400 \mathrm{MHz}$ spectrometer at room temperature unless otherwise started. Nondeuterated solvents were locked to standard external $\mathrm{CD}_{2} \mathrm{Cl}_{2}$ solutions. Residual protio solvent resonances were used as a reference for ${ }^{1} \mathrm{H}$ NMR spectra. ${ }^{2} \mathrm{H}$ NMR spectra were referenced to $\mathrm{CD}_{2} \mathrm{Cl}_{2}\left(\delta\right.$ 5.32). ${ }^{31} \mathrm{P}\left\{{ }^{1} \mathrm{H}\right\}$ NMR spectra were referenced externally to $85 \% \mathrm{H}_{3} \mathrm{PO}_{4}\left(\mathrm{D}_{2} \mathrm{O}\right)$. All chemical shifts $(\delta)$ are quoted in ppm and coupling constants in $\mathrm{Hz}$.

Solid state NMR (SSNMR) samples were prepared packing powdered microcrystalline sample into either a $3.2 \mathrm{~mm}$ or $4 \mathrm{~mm}$ zirconia solid state rotor inside an argon filled glove box. SSNMR spectra were obtained on a Bruker Avance III HD 
spectrometer equipped with a 9.4 Tesla magnet, operating at $100.6 \mathrm{MHz}$ for ${ }^{13} \mathrm{C}$ and $162 \mathrm{MHz}$ for ${ }^{31} \mathrm{P}$, respectively, and a MAS rate of $10 \mathrm{kHz}$. Relaxation time for ${ }^{1} \mathrm{H}$ and contact time for ${ }^{31} \mathrm{P}\left\{{ }^{1} \mathrm{H}\right\}$ CP/MAS, ${ }^{13} \mathrm{C}\left\{{ }^{1} \mathrm{H}\right\}$ CP/MAS, ${ }^{13} \mathrm{C}\left\{{ }^{1} \mathrm{H}\right\}$ NQS and FSLGHETCOR NMR experiments were optimized for each compound as appropriate. All ${ }^{13} \mathrm{C}\left\{{ }^{1} \mathrm{H}\right\}$ CP/MAS spectra were referenced to adamantane (up field methine resonance, $\delta 29.5)^{S 3}$ on a scale where $\delta(T M S)=0$ as a secondary reference. The temperature for Variable Temperature (VT) NMR experiments at low temperatures was externally calibrated using lead nitrate $\left(\mathrm{PbNO}_{3}\right)$. The ${ }^{1} \mathrm{H}$ chemical shifts obtained from ${ }^{1} \mathrm{H} /{ }^{13} \mathrm{C}$ Frequency Switched Lee-Goldburg HETCOR SSNMR spectra were referenced internally to the $p$-ArH resonance of the $\left[\mathrm{BAr}_{4}\right]^{-}(\delta=7.12) .{ }^{\mathrm{S}}{ }^{-}$

Gas phase ${ }^{1} \mathrm{H}$ NMR spectroscopy was carried out using a Bruker Ascend $400 \mathrm{MHz}$ spectrometer. The spectrometer was pre-locked and shimmed to a separate $\mathrm{CD}_{2} \mathrm{Cl}_{2}$ sample in a similar bore tube. The T1 delay was set to $1 \mathrm{~s}$, and this has been previously shown to allow for the accurate comparison of integrals. ${ }^{\mathrm{S5}}$

Electrospray ionization mass spectrometry (ESI-MS) was carried out using a Bruker MicrOTOF instrument directly connected to a modified Innovative Technology glovebox. ${ }^{56}$ Typical acquisition parameters were used (sample flow rate: $4 \mu \mathrm{L} \mathrm{min}{ }^{-1}$, nebulizer gas pressure: 0.4 bar, drying gas: Argon at $333 \mathrm{~K}$ flowing at $4 \mathrm{~L} \mathrm{~min}{ }^{-1}$, capillary voltage: $4.5 \mathrm{kV}$, exit voltage: $60 \mathrm{~V}$ ). The spectrometer was calibrated using a mixture of tetraalkyl ammonium bromides $\left[\mathrm{N}\left(\mathrm{C}_{n} \mathrm{H}_{2 n+1}\right)_{4}\right] \mathrm{Br}(\mathrm{n}=2-8,12,16$ and 18). Samples were diluted to a concentration of $1 \times 10^{-6} \mathrm{M}$ in the appropriate solvent before sampling by ESI-MS.

Gas Chromatography Electron lonization-Mass Spectrometry (GC EI-MS) analyses were performed on an Agilent 7200 quadrupole time of flight (Q-ToF) instrument equipped with a 7890B gas chromatograph and a PAL auto-sampler fitted with a 2.5 $\mathrm{mL}$ headspaces syringe. Instrument control and data processing were performed using Agilent MassHunter software. The system was calibrated within 1 hour prior to the analysis and its mass accuracy with external calibration (as used for these experiments) is better than $5 \mathrm{ppm}$ for 2 hours following calibration. Samples were prepared in $20 \mathrm{~mL}$ headspace vials. Vials were incubated at $35^{\circ} \mathrm{C}$ for 30 seconds before a $2.5 \mathrm{~mL}$ sample of the headspace was taken and injected into the GC inlet (headspace syringe was held at $40^{\circ} \mathrm{C}$ ). The GC-inlet was operated in split mode held 
at $300{ }^{\circ} \mathrm{C}$ with a 2:1 split. The column was a Restek RT Q-Bond $30 \mathrm{~m} \times 320 \mu \mathrm{m}$ with at $10 \mu \mathrm{m}$ film thickness. The oven was held at $40{ }^{\circ} \mathrm{C}$ for $4 \mathrm{~min}$ then ramped at 20 ${ }^{\circ} \mathrm{C} / \mathrm{min}$ to 300 and held for $3 \mathrm{~min}$. Column flow rate was $1 \mathrm{~mL} / \mathrm{min}$. Mass spectrometer was operated in $\mathrm{El}$ mode and with the ionization energy set to $20 \mathrm{eV}$.

Elemental analyses were conducted by Mr. Stephan Boyer at London Metropolitan University. 


\section{S.2. Synthetic procedures}

\section{S.2.1. $\left[\mathrm{Rh}\left(\mathrm{Cy}_{2} \mathrm{PCH}_{2} \mathrm{CH}_{2} \mathrm{PCy}_{2}\right)\left(\mathrm{C}_{4} \mathrm{H}_{8}\right)\right]\left[\mathrm{BAr}_{4}\right],\left[1-\mathrm{C}_{4} \mathrm{H}_{8}\right]\left[\mathrm{BAr}_{4}{ }_{4}\right]$}

\section{S.2.1.1. Synthesis of $\left[1-\mathrm{C}_{4} \mathrm{H}_{8}\right]\left[\mathrm{BAr}_{4}{ }_{4}\right]$}

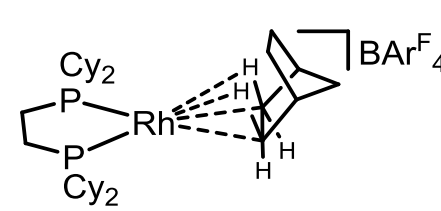

[1-NBA][BArF ${ }_{4}$ ]

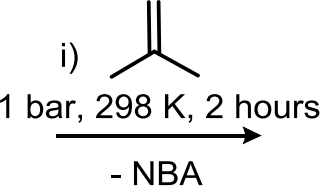

ii) Recryst from $\mathrm{CH}_{2} \mathrm{Cl}_{2}$ : pentane

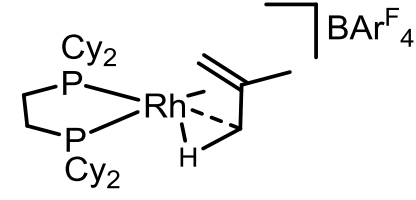

$\left[1-\mathrm{C}_{4} \mathrm{H}_{8}\right]\left[\mathrm{BAr}_{4}\right]$

To an orange sample of crystalline [1-NBA][BAr${ }_{4}$ ] $(200 \mathrm{mg}, 135 \mu \mathrm{mol})$ in an evacuated $\left(<3 \times 10^{-2} \mathrm{mbar}\right) \mathrm{J}$ Young flask $(\sim 50 \mathrm{~mL})$ isobutene gas (1 bar, $298 \mathrm{~K}$ ) was added and left to stand for 2 hours, to form $\left[\mathrm{Rh}\left(\mathrm{Cy}_{2} \mathrm{PCH}_{2} \mathrm{CH}_{2} \mathrm{PCy}_{2}\right)\left(\mathrm{C}_{4} \mathrm{H}_{8}\right)\right]\left[\mathrm{BAr}_{4}{ }_{4}\right],\left[1-\mathrm{C}_{4} \mathrm{H}_{8}\right]\left[\mathrm{BAr}_{4}^{\mathrm{F}}\right]$. After this time, working under an atmosphere of isobutene ( 1 bar) and at $-78{ }^{\circ} \mathrm{C}$ in an acetone/dry ice bath, the sample was dissolved in $\mathrm{CH}_{2} \mathrm{Cl}_{2}(3 \mathrm{~mL})$, filtered via cannula and layered with pentane $(25 \mathrm{~mL})$ at the same temperature. The solution was warmed to ambient temperature and after 3 days yielded orange block like crystals suitable for single crystal x-ray diffraction. Yield: $169 \mathrm{mg}$ (86\%). The crystalline material is stored in a glove box in a freezer operating at $-25^{\circ} \mathrm{C}$.

Note: $\mathrm{CH}_{2} \mathrm{Cl}_{2}$ and pentane used in this preparation were freeze-pump-thawed degassed three times and then saturated and stored with isobutene gas (1 bar) prior to use. When solvents were left under an argon atmosphere, $50 \%$ decomposition of $\left[1-\mathrm{C}_{4} \mathrm{H}_{8}\right]\left[\mathrm{BAr}_{4} \mathrm{~F}_{4} \text { to [1-BAr}{ }_{4}\right]^{\mathrm{S} 2}$ occurs in 2 hours. 


\section{S.2.1.2. Characterization data for $\left[1-\mathrm{C}_{4} \mathrm{H}_{8}\right]\left[\mathrm{BAr}_{4}{ }_{4}\right]$}

${ }^{1} \mathrm{H}$ NMR $\left(\mathrm{CD}_{2} \mathrm{Cl}_{2}, 298 \mathrm{~K}, 400 \mathrm{MHz}\right): \delta 7.72$ (s, 8H, ortho-ArH), 7.55 (s, 4H, paraArH), 2.09-1.64 (br m, 28H, overlapping aliphatic $\mathrm{CH}$ ), 1.61-1.42 (br s, 8H, aliphatic $\mathrm{CH}), 1.40-1.0 .96$ (br m, 20H, overlapping aliphatic $\mathrm{CH}$ ).

${ }^{1} \mathrm{H}$ NMR $\left(\mathrm{CD}_{2} \mathrm{Cl}_{2}, 183 \mathrm{~K}, 400 \mathrm{MHz}\right): \delta 7.75$ (s, 8H, ortho-ArH), 7.56 (s, 4H, para$\mathrm{ArH}$ ), 3.75 (br s, $\sim 2 \mathrm{H}$, alkene $\mathrm{CH}$ ), 2.09-1.64 (br m, $30 \mathrm{H}$, overlapping aliphatic $\mathrm{CH}$ ), 1.40-1.09 (br m, 20H, overlapping aliphatic $\mathrm{CH}$ ), -0.15 (br, $\mathrm{CH}_{3}$ ).

Note: The low temperature limit was not reached at $183 \mathrm{~K}$ in the ${ }^{1} \mathrm{H}$ NMR spectrum' so integrated values are approximate. NMR samples prepared under argon and immediately run after preparation.

${ }^{31} \mathrm{P}\left\{{ }^{1} \mathrm{H}\right\} \operatorname{NMR}\left(\mathrm{CD}_{2} \mathrm{Cl}_{2}, 298 \mathrm{~K}, 162 \mathrm{MHz}\right): \delta 95.3\left(\mathrm{~d}, \mathrm{~J}_{\mathrm{RhP}} 179 \mathrm{~Hz}\right)$.

${ }^{31} \mathrm{P}\left\{{ }^{1} \mathrm{H}\right\} \operatorname{NMR}\left(\mathrm{CD}_{2} \mathrm{Cl}_{2}, 183 \mathrm{~K}, 162 \mathrm{MHz}\right): \delta 97.6$ (dd., J JhP $201 \mathrm{~Hz}, \mathrm{JPP}_{\mathrm{PP}} 26 \mathrm{~Hz}$ trans to agostic interaction), 93.6 (d. of d., $\mathrm{J}_{\mathrm{RhP}} 158 \mathrm{~Hz}, \mathrm{~J}_{\mathrm{PP}} 26 \mathrm{~Hz}$ trans to alkene).

${ }^{19} \mathrm{~F}\left\{{ }^{1} \mathrm{H}\right\} \operatorname{NMR}\left(\mathrm{CD}_{2} \mathrm{Cl}_{2}, 298 \mathrm{~K}, 377 \mathrm{MHz}\right): \delta-62.9(\mathrm{~s})$.

${ }^{13} \mathrm{C}\left\{{ }^{1} \mathrm{H}\right\}$ NMR $\left(\mathrm{CD}_{2} \mathrm{Cl}_{2}, 298 \mathrm{~K}, 126 \mathrm{MHz}\right): \delta 161.1$ (1:1:1:1 q, J $\mathrm{JB}_{\mathrm{CB}} 50 \mathrm{~Hz}$, ipso-ArC), 134.6 (s, ortho-ArC), 128.8 (q, J J $32 \mathrm{~Hz}$, meta-ArC), 124.8 (q, J J $272 \mathrm{~Hz}, \mathrm{CF}_{3}$ ), 117.3 (s, para-ArC), 53.8 (qu. $\mathrm{CD}_{2} \mathrm{Cl}_{2}$ ), 37.3 (s, cyclohexyl-CH), 30.9 (s, cyclohexyl$\mathrm{CH}_{2}$ ), 29.9 (s, cyclohexyl- $\mathrm{CH}_{2}$ ), 29.6 (s, cyclohexyl- $\mathrm{CH}_{2}$ ), 29.2 (s, cyclohexyl- $\mathrm{CH}_{2}$ ), 26.5 (cyclohexyl- $\mathrm{CH}_{2}$ ), 25.7 (cyclohexyl- $\mathrm{CH}_{2}$ ), 25.3 (cyclohexyl-CH2), 22.1 (s, cyclohexyl- $\mathrm{CH}_{2}$ ).

${ }^{13} \mathrm{C}\left\{{ }^{1} \mathrm{H}\right\}$ NMR $\left(\mathrm{CD}_{2} \mathrm{Cl}_{2}, 183 \mathrm{~K}, 126 \mathrm{MHz}\right): \delta 161.1$ (1:1:1:1 q, J $\mathrm{J}_{\mathrm{CB}} 50 \mathrm{~Hz}$, ipso-ArC), 134.6 (s, ortho-ArC), 128.8 (q, J J $32 \mathrm{~Hz}$, meta-ArC), 124.8 (q, J JF $272 \mathrm{~Hz}, \mathrm{CF}_{3}$ ), 117.3 (s, para-ArC), 111.5 (br s, alkene-CH), 72.6 (br s, alkene-CH), 53.8 (qu. $\mathrm{CD}_{2} \mathrm{Cl}_{2}$ ), 36.7 (br s.), 35.2 (br s.), 31.1 (s, cyclohexyl- $\mathrm{CH}_{2}$ ), 29.4 (m, cyclohexyl- $\mathrm{CH}_{2}$ ), 25.6 (s, cyclohexyl- $\mathrm{CH}_{2}$ ), 24.9 (s, cyclohexyl- $\mathrm{CH}_{2}$ ), 24.3 (s, cyclohexyl- $\mathrm{CH}_{2}$ ), 22.2 (s, cyclohexyl- $\mathrm{CH}_{2}$ ), 19.4 (br. s).

${ }^{31} \mathrm{P}\left\{{ }^{1} \mathrm{H}\right\}$ SSNMR (162 MHz, $158 \mathrm{~K}, 10 \mathrm{kHz}$ spin rate): $\delta 94.8$ (br m, coincident environments). 
${ }^{13} \mathrm{C}\left\{{ }^{1} \mathrm{H}\right\}$ SSNMR (101 MHz, 158K, $10 \mathrm{kHz}$ spin rate): $\delta 161.1$ (ipso-ArC), 131.2 (ortho-ArC), 127.4 (meta-ArC), 122.9 (br, $\mathrm{CF}_{3}$ ), 115.6 (para-ArC), 113.1 (para-ArC), $108.6\left(\mathbf{C}=\mathrm{CH}_{2}\right), 70.6\left(\mathrm{C}=\mathrm{CH}_{2}\right), 35.7,34.3,31.2,29.8,27.5,24.1,22.7,21.9,15.7$.

Note: Signals at 108.6 and 70.6 disappeared upon addition of $\mathrm{H}_{2}$, to form [1$\mathrm{C}_{4} \mathrm{H}_{10}$ ][BAr ${ }_{4}{ }_{4}$. The agostic $-\mathrm{CH}_{3}$ could not be unambiguously identified, see section S.2.2.

ESI-MS: Not stable under mass spectrometric conditions (20eV, 333K). Species with appropriate isotopic distributions at $\mathrm{m} / \mathrm{z}$ found $=581.240$, calculated to $\left[\left(\mathrm{Cy}_{2} \mathrm{PCH}_{2} \mathrm{CH}_{2} \mathrm{PCy}\right) \mathrm{Rh}\left(\mathrm{N}_{2}\right)_{2}\right]^{+}$(581.242). There is no evidence for the nitrogen compound in bulk samples so it is assumed to form via an in-situ ESI-MS process.

Elemental analysis found (calc. for $\mathrm{C}_{62} \mathrm{H}_{68} \mathrm{BF}_{24} \mathrm{P}_{2} \mathrm{Rh}$ ): C 52.39 (51.54), $\mathrm{H} 4.87$ (4.74). 


\section{S.2.1.3. NMR spectra of $\left[1-\mathrm{C}_{4} \mathrm{H}_{8}\right]\left[B A \mathrm{Br}_{4}\right]$}

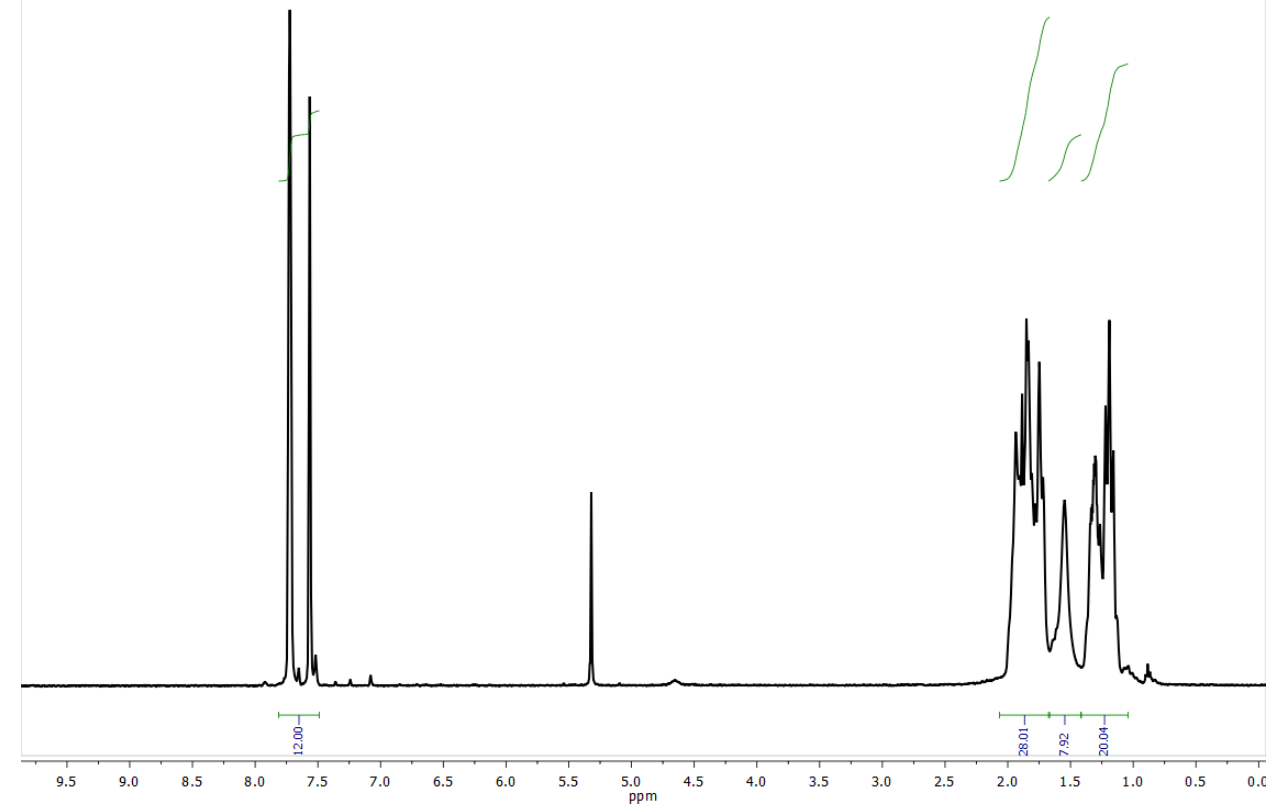

Figure S1: The solution ${ }^{1} \mathrm{H}$ NMR $\left(\mathrm{CD}_{2} \mathrm{Cl}_{2}, 298 \mathrm{~K}, 400 \mathrm{MHz}\right)$ spectrum of [1$\left.\mathrm{C}_{4} \mathrm{H}_{8}\right]\left[\mathrm{BAr}_{4}{ }^{\mathrm{F}}\right.$.
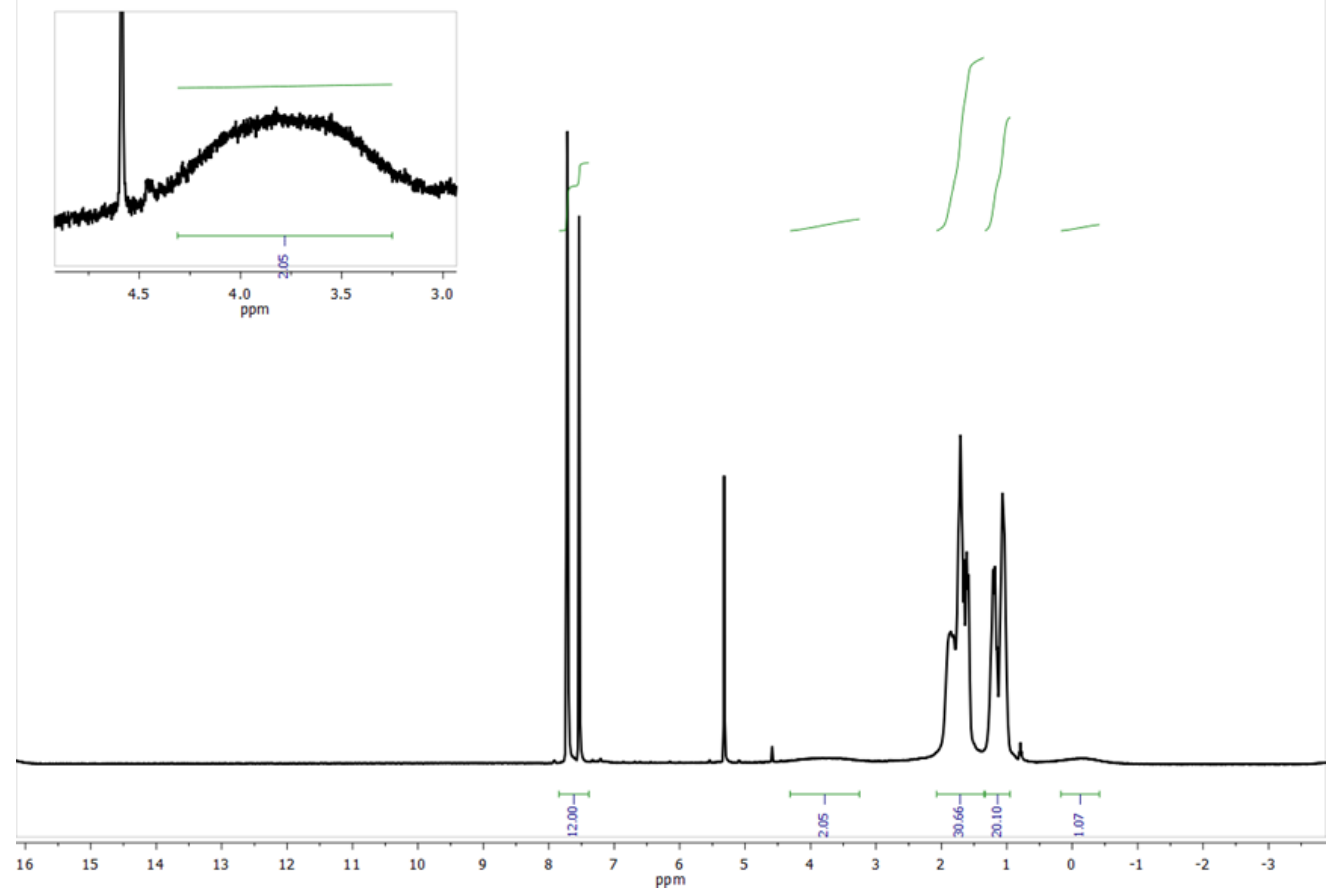

Figure S2: The solution ${ }^{1} \mathrm{H}$ NMR $\left(\mathrm{CD}_{2} \mathrm{Cl}_{2}, 183 \mathrm{~K}, 400 \mathrm{MHz}\right)$ spectrum of [1$\mathrm{C}_{4} \mathrm{H}_{8}$ ][BAr${ }_{4}{ }_{4}$. The low temperature limit was not reached at $183 \mathrm{~K}$, so integrated values are approximate. 


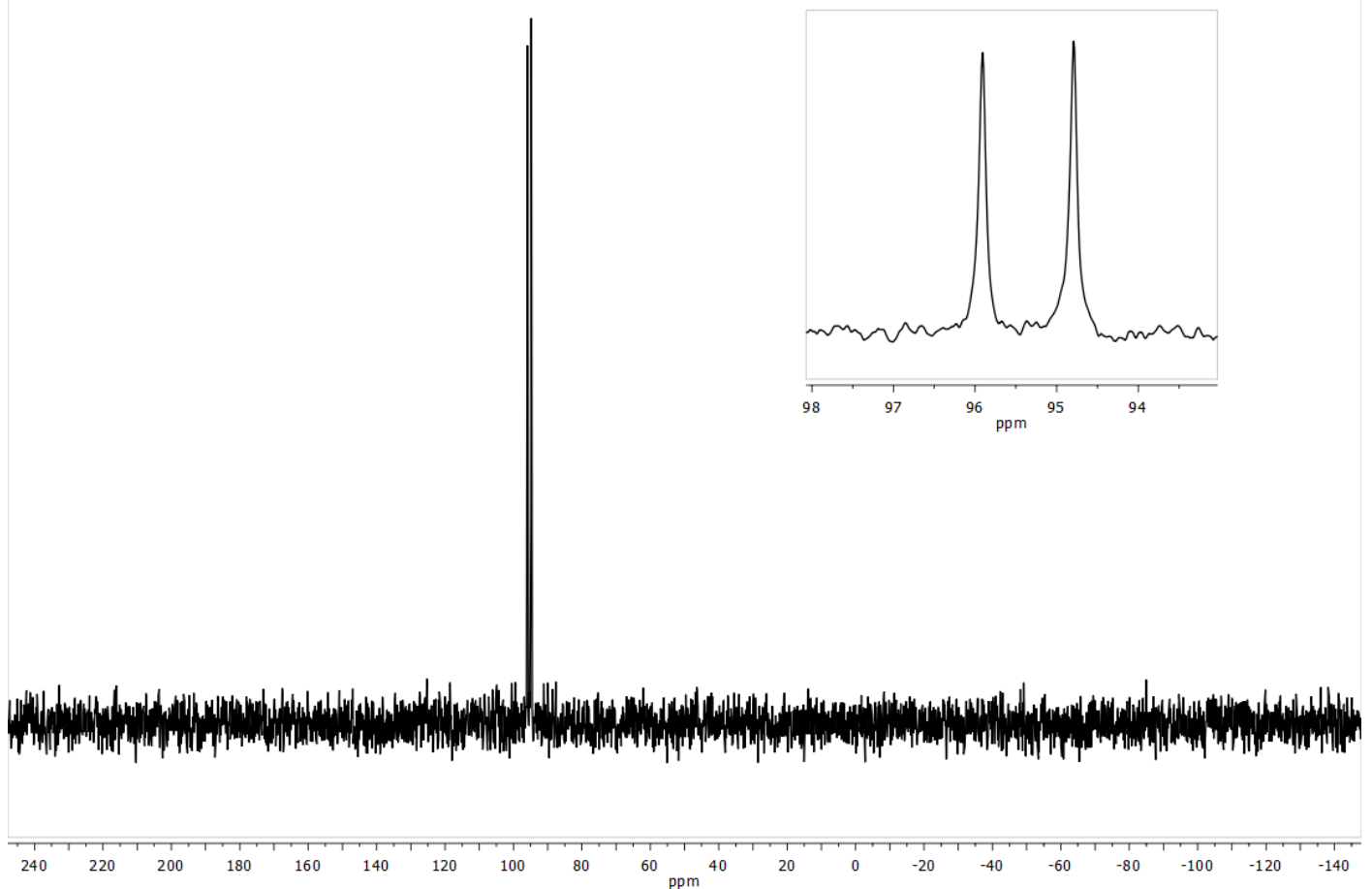

Figure S3: The solution ${ }^{31} \mathrm{P}\left\{{ }^{1} \mathrm{H}\right\} \mathrm{NMR}\left(\mathrm{CD}_{2} \mathrm{Cl}_{2}, 298 \mathrm{~K}, 162 \mathrm{MHz}\right)$ spectrum of [1$\left.\mathrm{C}_{4} \mathrm{H}_{8}\right]\left[\mathrm{BAr}_{4}{ }_{4}\right]$.

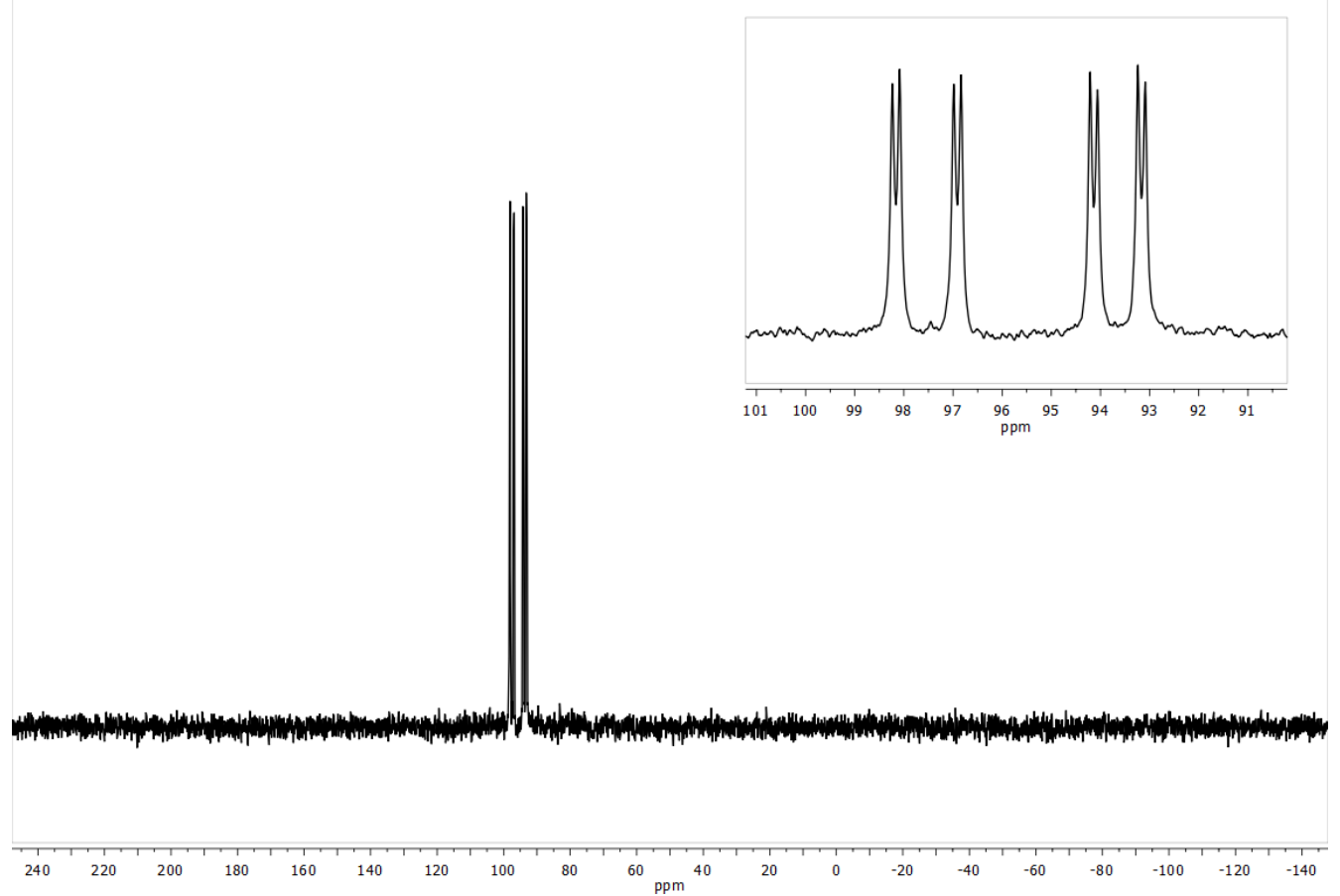

Figure S4: The solution ${ }^{31} \mathrm{P}\left\{{ }^{1} \mathrm{H}\right\} \mathrm{NMR}\left(\mathrm{CD}_{2} \mathrm{Cl}_{2}, 183 \mathrm{~K}, 162 \mathrm{MHz}\right)$ spectrum of [1$\left.\mathrm{C}_{4} \mathrm{H}_{8}\right]\left[\mathrm{BAr}_{4}{ }_{4}\right.$. 


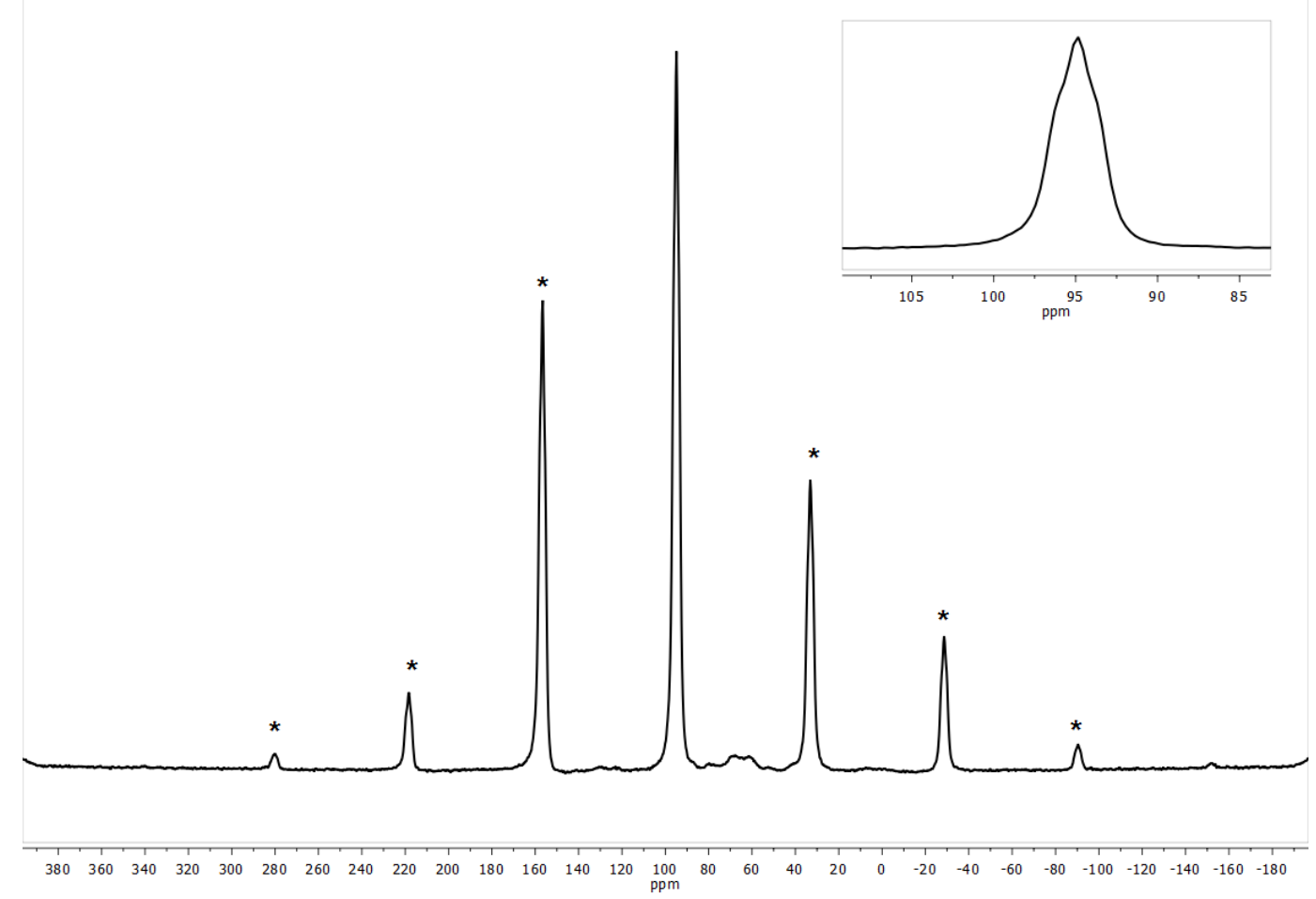

Figure S5: The ${ }^{31} \mathrm{P}\left\{{ }^{1} \mathrm{H}\right\}$ SSNMR (162 MHz, $158 \mathrm{~K}, 10 \mathrm{kHz}$ spin rate) spectrum of [1$\left.\mathrm{C}_{4} \mathrm{H}_{8}\right]\left[\mathrm{BAr}_{4}{ }_{4}\right.$. The resonances marked ${ }^{*}$ are due to spinning sidebands.

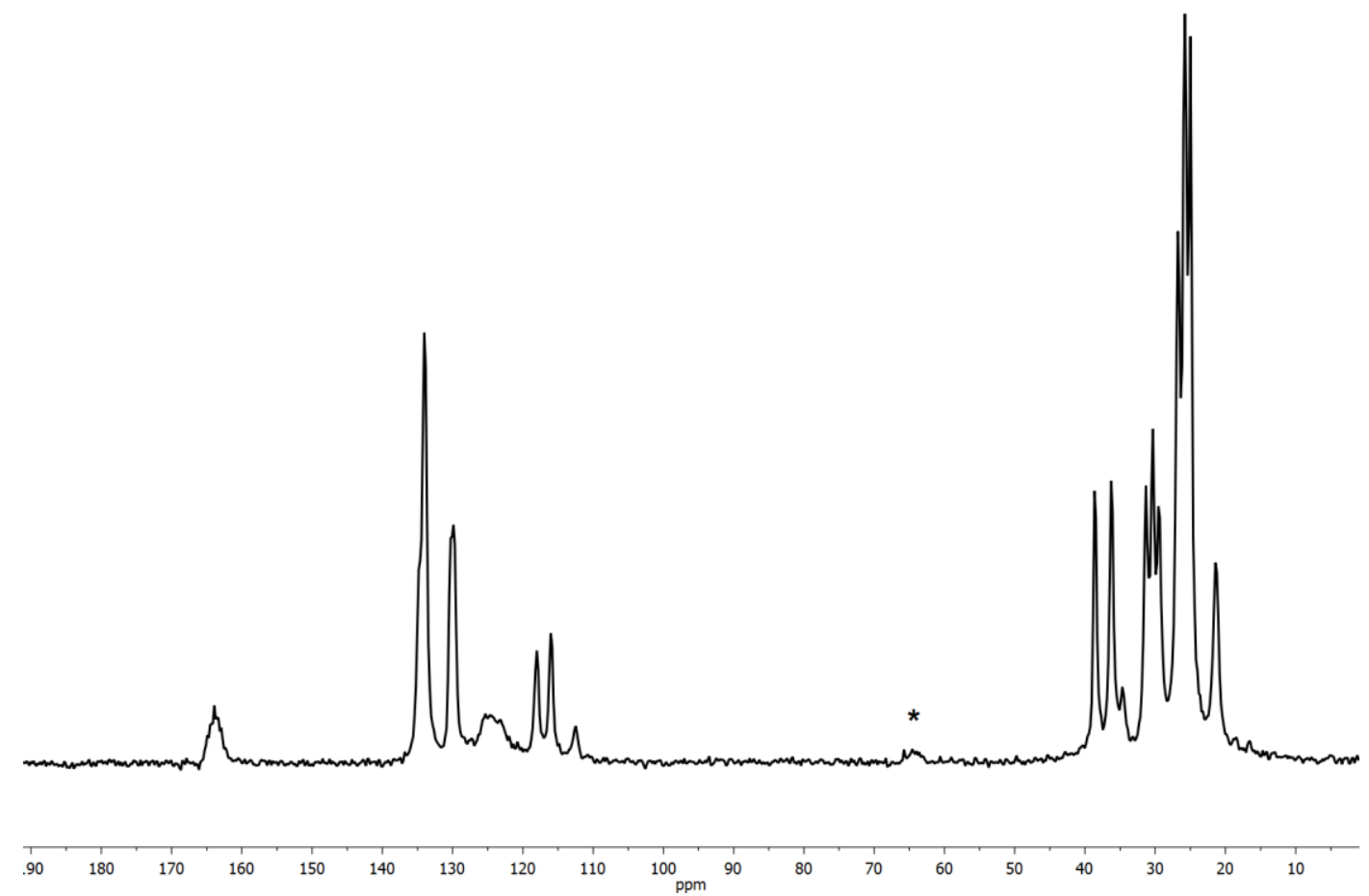

Figure S6: The ${ }^{13} \mathrm{C}\left\{{ }^{1} \mathrm{H}\right\}$ SSNMR (101 MHz, $298 \mathrm{~K}, 10 \mathrm{kHz}$ spin rate) spectrum of [1$\left.\mathrm{C}_{4} \mathrm{H}_{8}\right]\left[\mathrm{BAr}_{4}{ }_{4}\right.$. The resonances marked ${ }^{*}$ are due to spinning sidebands. 


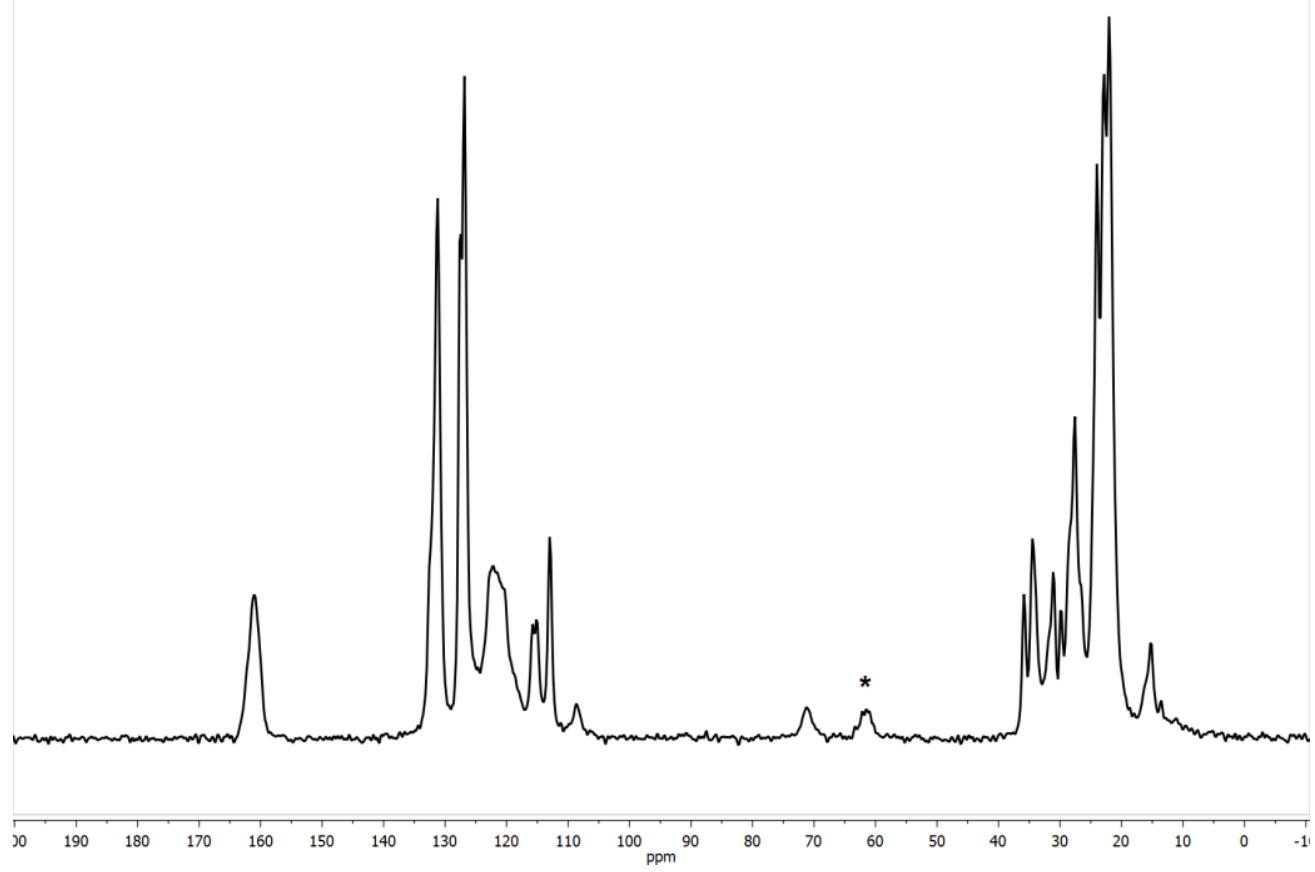

Figure S7: The ${ }^{13} \mathrm{C}\left\{{ }^{1} \mathrm{H}\right\}$ SSNMR (101 MHz, $158 \mathrm{~K}, 10 \mathrm{kHz}$ spin rate) spectrum of [1$\left.\mathrm{C}_{4} \mathrm{H}_{8}\right]\left[\mathrm{BAr}{ }_{4}\right]$. The resonances marked ${ }^{*}$ are due to spinning sidebands.
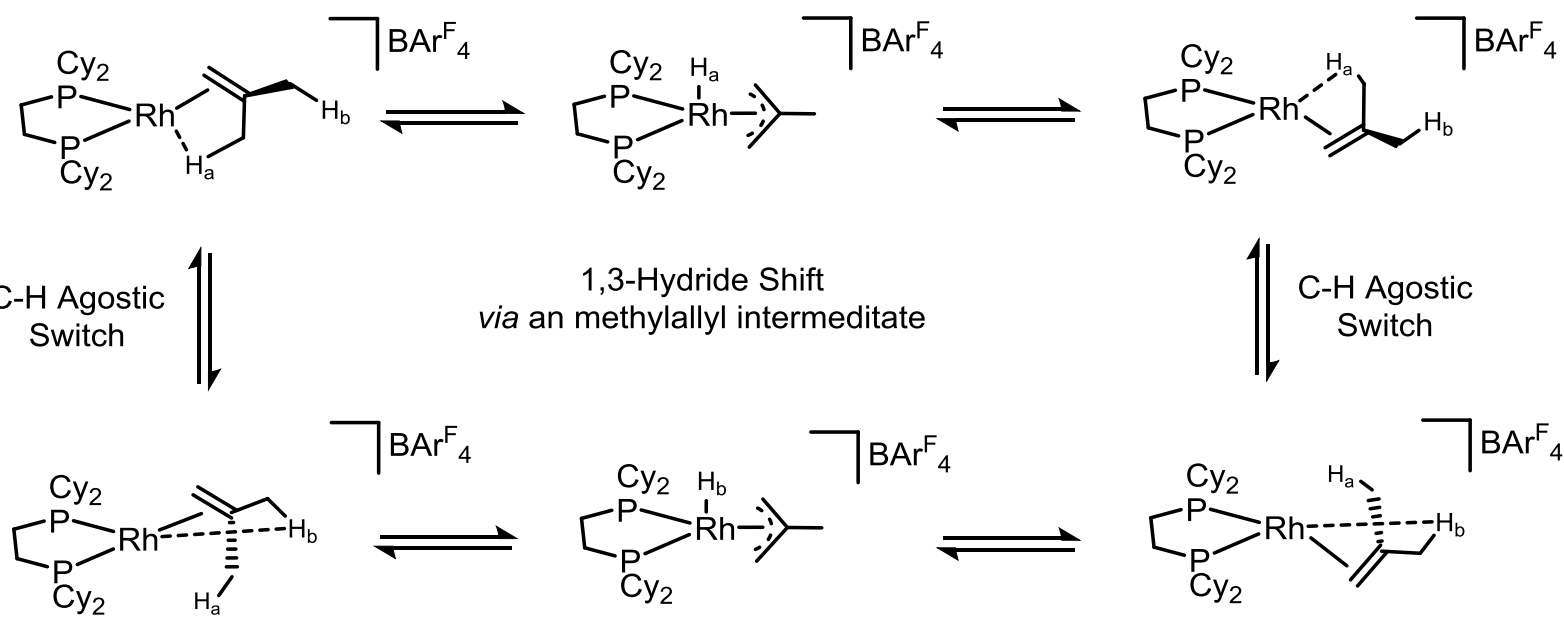

Figure S8: Proposed structural diagrams of the species and mechanism of the fluxional nature of the isobutene ligand of [1- $\left.\mathrm{C}_{4} \mathrm{H}_{8}\right]\left[\mathrm{BAr}_{4}{ }_{4}\right]$, in both solution and solidstates. 


\section{S.2.2. $\left[\mathrm{Rh}\left(\mathrm{Cy}_{2} \mathrm{PCH}_{2} \mathrm{CH}_{2} \mathrm{PCy}_{2}\right)\left(\mathrm{C}_{4} \mathrm{H}_{10}\right)\right]\left[B A \mathrm{~F}_{4}^{\mathrm{F}}\right],\left[1-\mathrm{C}_{4} \mathrm{H}_{10}\right]\left[\mathrm{BAr}{ }_{4}\right]$}

\section{S.2.2.1. Synthesis of $\left[1-\mathrm{C}_{4} \mathrm{H}_{10}\right]\left[B \mathrm{Br}_{4}{ }_{4}\right]$ for an $\mathrm{x}$-ray diffraction study}

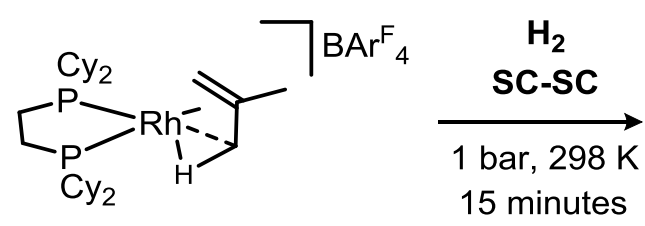

$\left[1-\mathrm{C}_{4} \mathrm{H}_{8}\right]\left[\mathrm{BAr}{ }_{4}\right]$

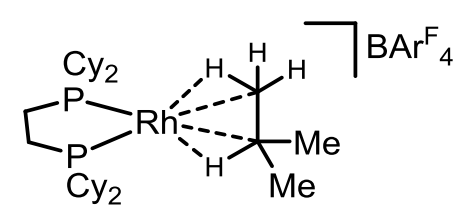

$\left[1-\mathrm{C}_{4} \mathrm{H}_{10}\right]\left[\mathrm{BArF}_{4}\right]$

Orange crystals of $\left[1-\mathrm{C}_{4} \mathrm{H}_{8}\right]\left[\mathrm{BAr}{ }_{4}\right]$ were treated with $\mathrm{H}_{2}$ (1 bar, $298 \mathrm{~K}, 15$ mins) inside a $\mathrm{J}$ Young flask. The color of the crystals immediately turned a dark red. The crystalline material was then coated with Fomblin $\AA^{\circledR}$ Y oil under an argon-flush; a suitable crystal was rapidly selected and then transferred to the Cryostream of a diffractometer and an x-ray diffraction study was undertaken. For further details of structural refinement please refer to section S.5.

\section{S.2.2.2. Synthesis of $\left[1-\mathrm{C}_{4} \mathrm{H}_{10}\right]\left[B \mathrm{Br}_{4}{ }_{4}\right]$ for SSNMR characterization}

A powdered microcrystalline sample of $\left[1-\mathbf{C}_{4} \mathbf{H}_{8}\right]\left[B \mathbf{B r}^{\mathrm{F}}{ }_{4}\right](35 \mathrm{mg})$ was packed in a 3.2 mm SSNMR rotor, inside an argon filled glove box. The rotor was then placed in a custom built glass $\mathrm{J}$ Young flask ${ }^{\mathrm{S7}}$ and the sample was then exposed to $\mathrm{H}_{2}$ (1 bar, $298 \mathrm{~K}$ ). After 15 minutes, the rotor cap was fitted under a flush of $\mathrm{H}_{2}$. The sample was immediately transferred to the bore of a pre-cooled (158 K) SSNMR spectrometer ( 10 mins) and analyzed ${ }^{31} \mathrm{P}\left\{{ }^{1} \mathrm{H}\right\}$ and ${ }^{13} \mathrm{C}\left\{{ }^{1} \mathrm{H}\right\}$ solid state NMR spectroscopy.

These conditions were optimized to form $\left[1-\mathrm{C}_{4} \mathrm{H}_{10}\right]\left[B \mathrm{Br}_{4}{ }_{4}\right]$. At $158 \mathrm{~K}$, no onward reactivity with $\mathrm{H}_{2}$ is observed. When $\mathrm{H}_{2}$ replaced by argon at $298 \mathrm{~K}$, as so the rotor is packed under an argon atmosphere, dehydrogenation to re-form $\left[1-\mathbf{C}_{4} \mathrm{H}_{8}\right]\left[\mathrm{BAr}{ }_{4}\right]$ is observed before cooling to $158 \mathrm{~K}$, see section S.4.1.1.

Further exposure to $\mathrm{H}_{2}$ (90 mins) at $298 \mathrm{~K}$ results in complete decomposition to [1BArF $_{4}$ ], see section S.2.2.6. 


\section{S.2.2.3. Characterization data for $\left[1-\mathrm{C}_{4} \mathrm{H}_{10}\right]\left[\mathrm{BAr}_{4}{ }_{4}\right]$}

${ }^{31} \mathrm{P}\left\{{ }^{1} \mathrm{H}\right\}$ SSNMR (162 MHz, 298K, $10 \mathrm{kHz}$ spin rate): $\delta 106.4$ (br m).

${ }^{31} \mathrm{P}\left\{{ }^{1} \mathrm{H}\right\}$ SSNMR (162 MHz, $158 \mathrm{~K}, 10 \mathrm{kHz}$ spin rate): $\delta 106.8$ (br, environments overlapping)

${ }^{13} \mathrm{C}\left\{{ }^{1} \mathrm{H}\right\}$ SSNMR (101 MHz, $158 \mathrm{~K}, 10 \mathrm{kHz}$ spin rate): $\delta 160.5(\operatorname{ArC}), 132.9(\operatorname{ArC})$, 127.1 ( $\mathrm{ArC}), 121.6$ (br, $\mathrm{CF}_{3}$ ), 114.9 (ArC), 112.8 (ArC), 35.0, 32.1, 27.9, 22.8, 17.3, 15.9 (multiple aliphatic resonances).

${ }^{1} \mathrm{H}$ projection from ${ }^{1} \mathrm{H} /{ }^{13} \mathrm{C}$ FSLG HETCOR SSNMR (10 kHz spin rate, $158 \mathrm{~K}$ ): $\delta 9.81$ (br), 7.12 (br), 0.7 (br), -3.4 (br). 


\section{S.2.2.4. Solid State NMR spectra of $\left[1-\mathrm{C}_{4} \mathrm{H}_{10}\right]\left[B A \mathrm{Br}_{4}\right]$}

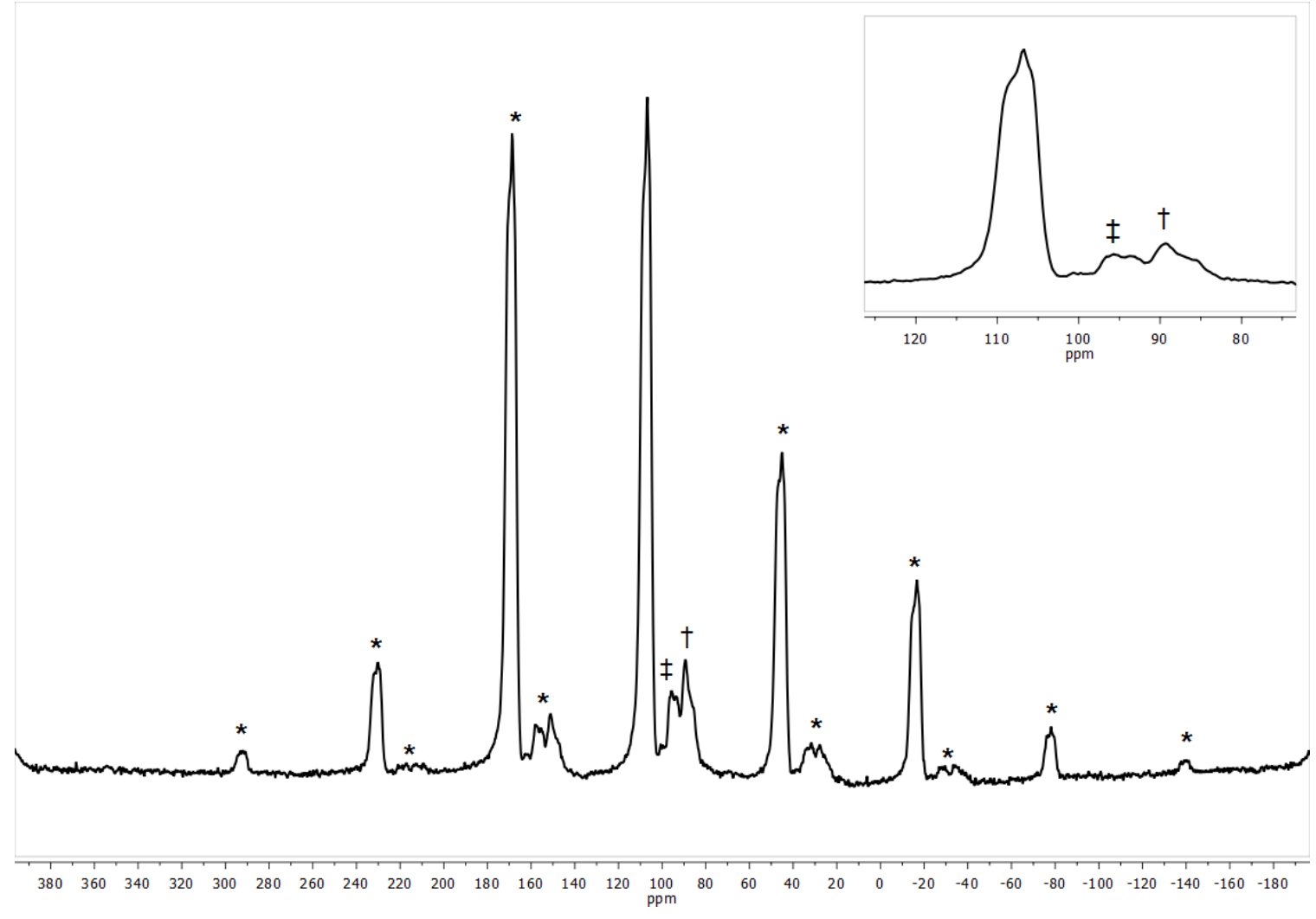

Figure S9: The ${ }^{31} \mathrm{P}\left\{{ }^{1} \mathrm{H}\right\}$ SSNMR (162 MHz, $158 \mathrm{~K}, 10 \mathrm{kHz}$ spin rate) spectrum of [1$\mathrm{C}_{4} \mathrm{H}_{10}$ ] $\left[B \mathrm{Br}_{4}{ }_{4}\right.$ prepared in situ after 15 mins under $\mathrm{H}_{2}$ at 298K.

The resonances marked $\neq$ are assigned to $\left[1-\mathrm{C}_{6} \mathrm{H}_{8}\right]\left[\mathrm{BAr}_{4}\right]$ from either incomplete hydrogenation or dehydrogenation of $\left[1-\mathrm{C}_{4} \mathrm{H}_{10}\right]\left[\mathrm{BAr}{ }_{4}\right]$ at $298 \mathrm{~K}$. The resonances marked $\dagger$ are assigned to an [1-B Ar ${ }_{4}$ ] decomposition product under $\mathrm{H}_{2}$ at $298 \mathrm{~K}$. The resonances marked * are due to spinning sidebands. The inset is an enlargement of the central resonances. 


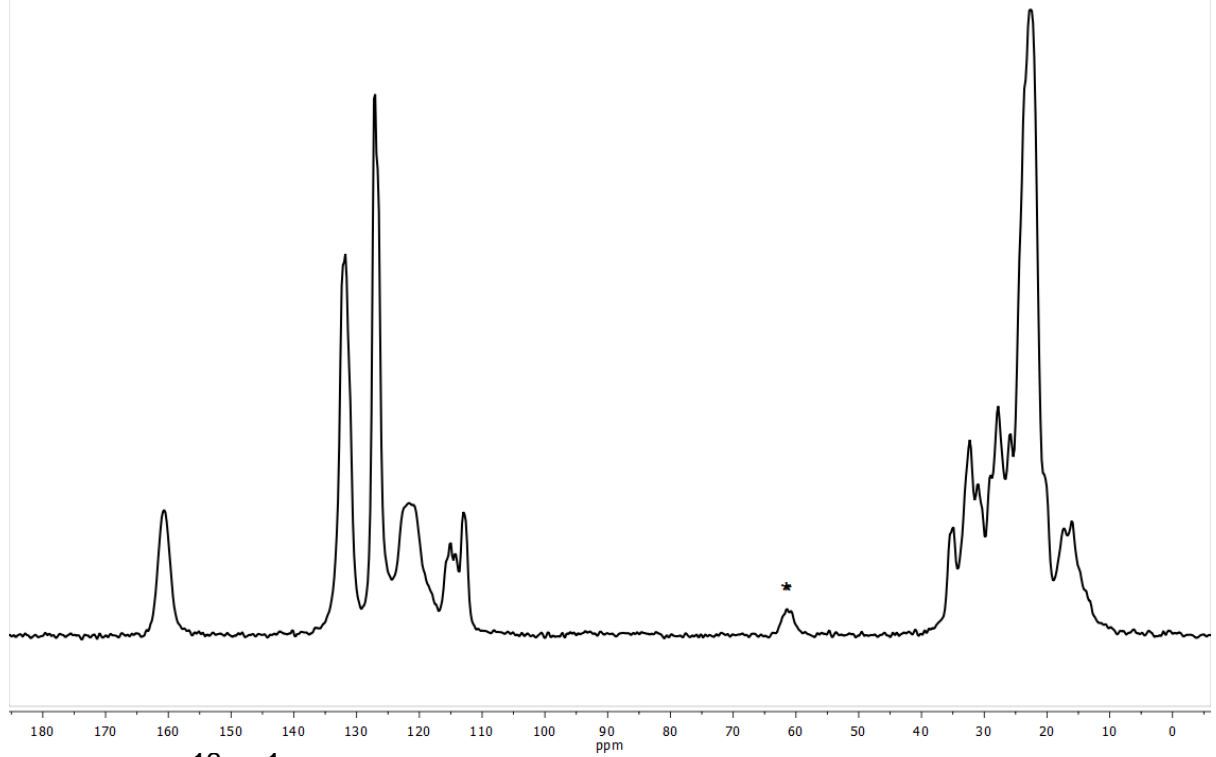

Figure S10: The ${ }^{13} \mathrm{C}\left\{{ }^{1} \mathrm{H}\right\}$ SSNMR $\left(100 \mathrm{MHz}, 158 \mathrm{~K}\right.$, under $\mathrm{H}_{2}, 10 \mathrm{kHz}$ spin rate) spectrum of $\left[1-\mathbf{C}_{4} \mathrm{H}_{10}\right]\left[\mathrm{BAr}{ }_{4}\right]$ prepared in situ at time of measuring. The resonance marked * is due to a spinning sideband.

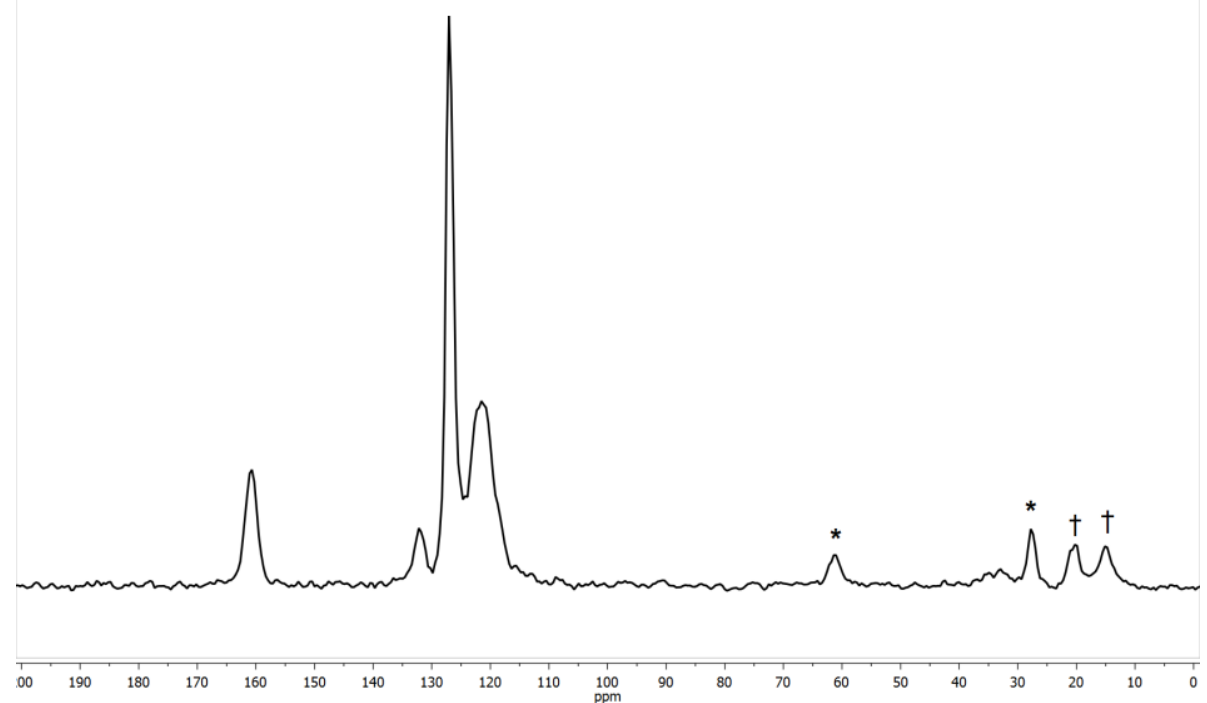

Figure S11: The ${ }^{13} \mathrm{C}\left\{{ }^{1} \mathrm{H}\right\}$ NQS SSNMR (100 MHz, $203 \mathrm{~K}, 10 \mathrm{kHz}$ spin rate) spectrum of [1- $\left.{ }_{4} \mathrm{H}_{10}\right]\left[\mathrm{BAr}_{4}{ }_{4}\right]$ prepared in situ. The resonances marked ${ }^{*}$ are due to spinning sidebands. Peaks marked $\dagger$ at $\delta \sim 21$ and $\delta \sim 15$ are assigned to the $\mathrm{C}_{4} \mathrm{H}_{10}$ fragment undergoing motion at $203 \mathrm{~K}$.

Note: When ${ }^{13} \mathrm{C}\left\{{ }^{1} \mathrm{H}\right\}$ NQS SSNMR was ran at $158 \mathrm{~K}$; the peaks marked $\dagger$ are absent, suggesting freezing out of any motion. 


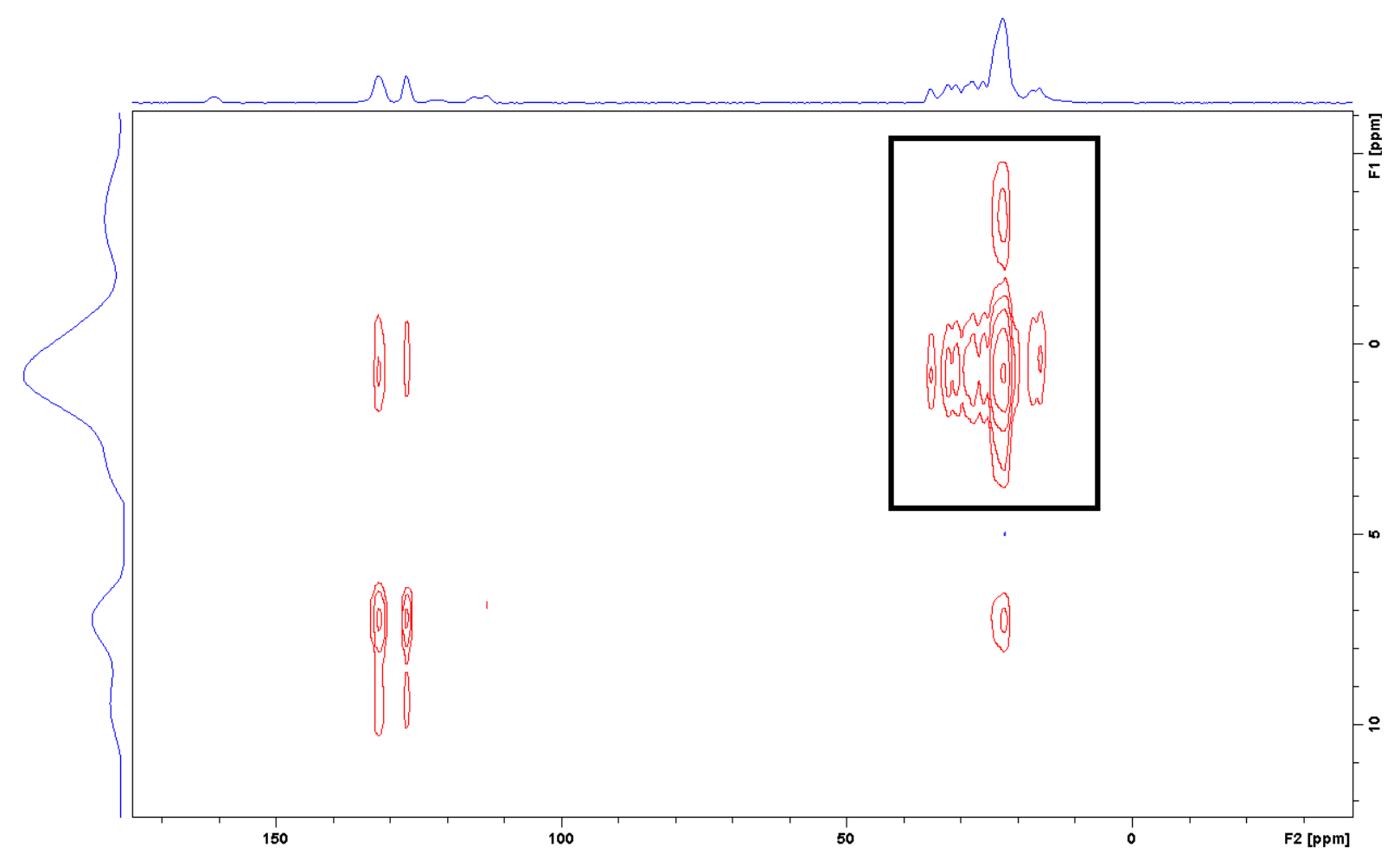

Figure S12: The ${ }^{1} \mathrm{H} /{ }^{13} \mathrm{C}$ FSLG HETCOR SSNMR (158 $\mathrm{K}, 10 \mathrm{kHz}$ spin rate) full spectrum of [1- $\left.\mathrm{C}_{4} \mathrm{H}_{10}\right]\left[\mathrm{BAr} \mathrm{F}_{4}\right]$. Enlargement of the alkyl region, shown by the black box, is shown below in Figure S13.

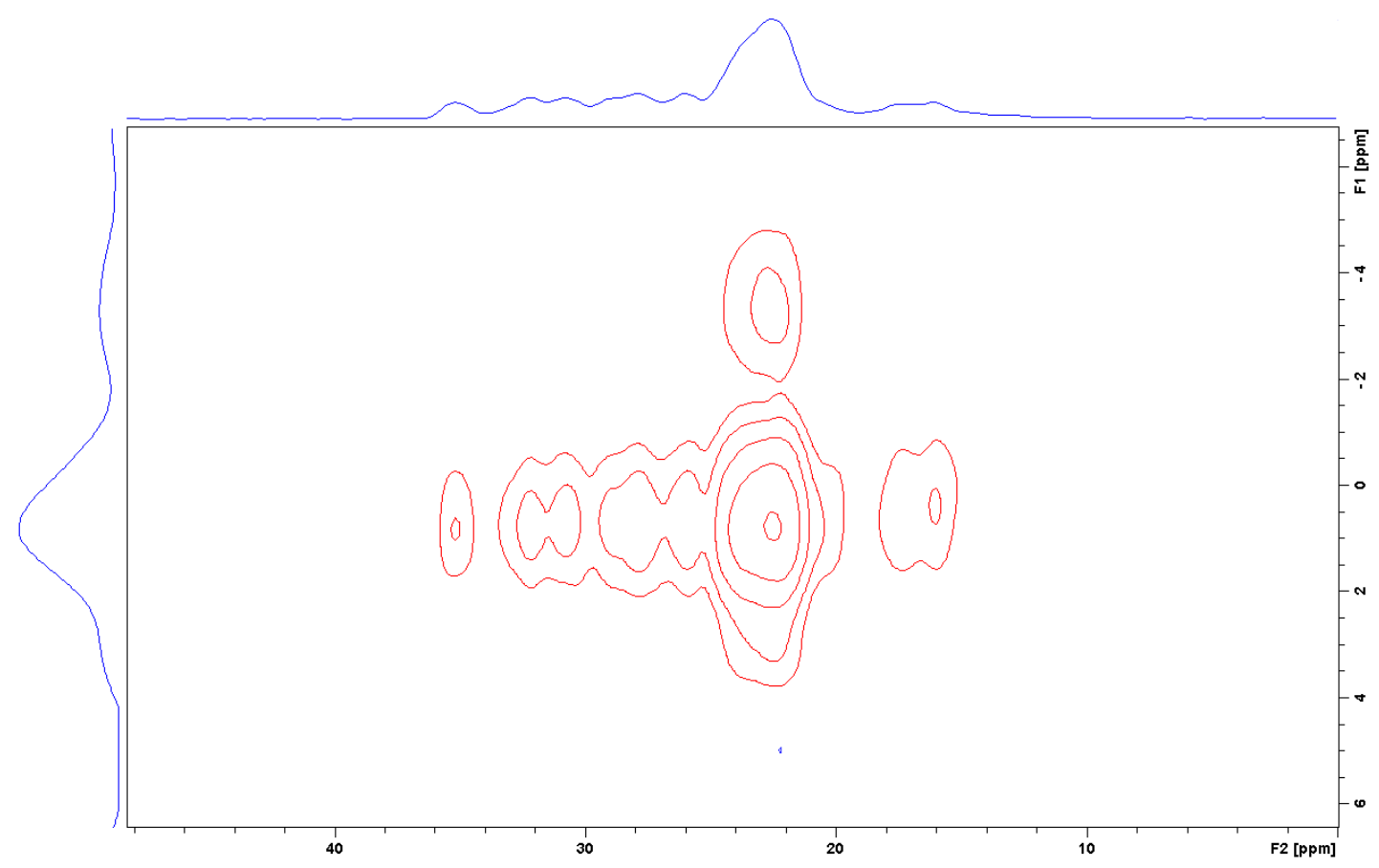

Figure S13: Enlargement of the ${ }^{1} \mathrm{H} /{ }^{13} \mathrm{C}$ FSLG HETCOR SSNMR $(158 \mathrm{~K}, 10 \mathrm{kHz}$ spin rate) spectrum of the alkyl region of $\left[1-\mathrm{C}_{4} \mathrm{H}_{10}\right]\left[\mathrm{BAr}_{4}\right]$. 


\section{S.2.2.5. Liberation of the bound isobutane from $\left[1-\mathrm{C}_{4} \mathrm{H}_{10}\right]\left[\mathrm{BAr}{ }_{4}\right]$.}

Orange crystals of $\left[1-\mathbf{C}_{4} \mathrm{H}_{8}\right]\left[\mathrm{BAr}_{4}{ }_{4}\right](20 \mathrm{mgs})$ were treated with $\mathrm{H}_{2}(1 \mathrm{bar}, 298 \mathrm{~K}, 15$ mins) inside a J Young flask. The color of the crystals immediately turned a dark red, yielding [1- $\left.\mathrm{C}_{4} \mathrm{H}_{10}\right]\left[\mathrm{BAr}{ }_{4}{ }_{4}\right]$. The solid was then cooled to $77 \mathrm{~K}$ under liquid nitrogen and the $\mathrm{J}$ Young flask placed under vacuum to remove any $\mathrm{H}_{2}$. $\mathrm{CO}$ (1 bar, 298K) was added and solid left for 1 hour; to which a vibrant yellow solid material had formed. The volatiles excluded from the lattice could be distilled into a fresh NMR tube with $\mathrm{d}_{3}-\mathrm{MeCN}$ and analyzed by ${ }^{1} \mathrm{H}$ NMR spectroscopy.

${ }^{1} \mathrm{H}$ NMR $\left(\mathrm{d}_{3}-\mathrm{MeCN}, 400 \mathrm{MHz}\right): \delta 1.72\left(\right.$ decet, $\left.1 \mathrm{H}, \underline{\mathrm{C}} \mathrm{H}\left(\mathrm{CH}_{3}\right)_{3}, \mathrm{~J}_{\mathrm{H}-\mathrm{H}}=6.79 \mathrm{~Hz}\right), 0.89$ (doublet, $9 \mathrm{H}, \mathrm{CH}\left(\underline{\mathrm{CH}}_{3}\right)_{3}, \mathrm{~J}_{\mathrm{H}-\mathrm{H}}=6.79 \mathrm{~Hz}$ ).

The resultant solid was confirmed to be $\left[\mathrm{Rh}(\mathrm{dcpe})(\mathrm{CO})_{2}\right]\left[\mathrm{BAr}{ }_{4}\right]$ by solution ${ }^{31} \mathrm{P}\left\{{ }^{1} \mathrm{H}\right\}$ NMR spectroscopy $\left(\delta 85.22, d, J_{R h P}=116 \mathrm{~Hz}\right) .{ }^{S 7}$ 


\section{S.2.2.6. Solid state decomposition products of $\left[1-\mathrm{C}_{4} \mathrm{H}_{10}\right]\left[B A \mathrm{Br}_{4}\right]$ under $\mathrm{H}_{2}$}

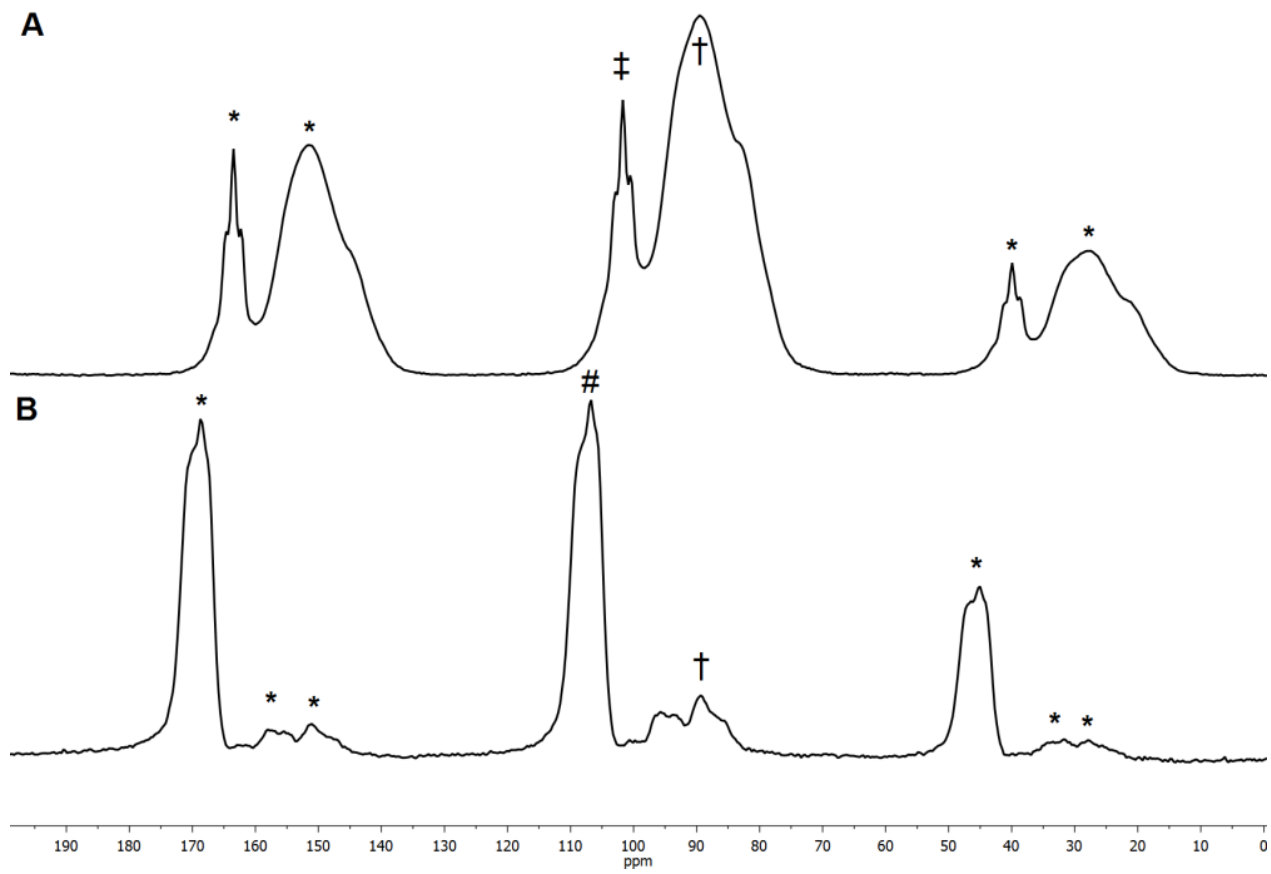

Figure S14: (A) The ${ }^{31} \mathrm{P}\left\{{ }^{1} \mathrm{H}\right\}$ SSNMR (162 MHz, $158 \mathrm{~K}, 10 \mathrm{kHz}$ spin rate) spectrum of [1- $\left.\mathrm{C}_{4} \mathrm{H}_{10}\right]\left[\mathrm{BAr}_{4}{ }_{4}\right]$ left in situ under an $\mathrm{H}_{2}$ atmosphere at $298 \mathrm{~K}$ for 90 mins. The peak assigned to $\dagger$ is the main decomposition product under $\mathrm{H}_{2}$, [1-BAr $\left.{ }_{4}\right]^{\mathrm{S} 2}$ (approx. $70 \%$ ) and $\ddagger$ is an unidentified complex under $\mathrm{H}_{2}$ (approx. $30 \%$ ).

(B) Repeat of Figure S9, showing the ${ }^{31} \mathrm{P}\left\{{ }^{1} \mathrm{H}\right\}$ SSNMR (162 MHz, $158 \mathrm{~K}, 10 \mathrm{kHz}$ spin rate) spectrum, where \# $=\left[1-\mathrm{C}_{4} \mathrm{H}_{10}\right]\left[B \mathrm{Br}_{4}{ }_{4}\right]$, to show no signals in $(\mathrm{A})$ relating to [1$\left.\mathrm{C}_{4} \mathrm{H}_{10}\right]\left[\mathrm{BAr}_{4}{ }_{4}\right]$ are present after hydrogenation for 90 mins. 


\section{S.2.3. $\left[\mathrm{Rh}\left(\mathrm{Cy}_{2} \mathrm{PCH}_{2} \mathrm{CH}_{2} \mathrm{PCy}_{2}\right)\left(\mathrm{C}_{6} \mathrm{H}_{8}\right)\right]\left[B A \mathrm{Br}_{4}\right],\left[1-\mathrm{C}_{6} \mathrm{H}_{8}\right]\left[\mathrm{BAr}{ }_{4}\right]$}

\section{S.2.3.1. Synthesis of $\left[1-\mathrm{C}_{6} \mathrm{H}_{8}\right]\left[\mathrm{BAr}_{4}{ }_{4}\right]$}

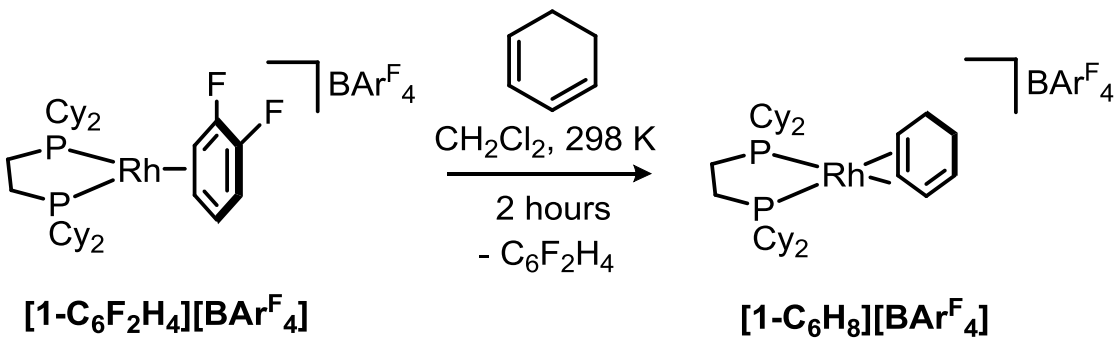

A solution of [1- $\left.\mathbf{C}_{6} \mathbf{H}_{4} \mathbf{F}_{2}\right]\left[B \mathrm{Ar}_{4}\right]$ (300 mg, $\left.0.20 \mathrm{mmol}\right)$ in $\mathrm{CH}_{2} \mathrm{Cl}_{2}(20 \mathrm{~mL})$ was treated with 1,3-cyclohexadiene $(200 \mu \mathrm{L})$ at ambient temperature. The resultant deep red solution was stirred at ambient temperature for 2 hours. Pentane $(100 \mathrm{~mL})$ was then added with vigorous stirring which resulted in the formation of a red precipitate. The solid was isolated by filtration, washed with pentane $(2 \times 20 \mathrm{~mL})$ and then dried under vacuum. The solid was then dissolved in $\mathrm{CH}_{2} \mathrm{Cl}_{2}(\sim 8 \mathrm{~mL})$ and filtered. The filtrate was then layered with pentane. Deep red crystals were obtained upon storage at $4{ }^{\circ} \mathrm{C}$ after 1 week. Yield: $204 \mathrm{mg}(70 \%)$.

Note: $\left[1-\mathrm{C}_{6} \mathrm{H}_{8}\right]\left[\mathrm{BAr}_{4}{ }_{4}\right]$ displays poor stability in solution at room temperature, particularly at high concentrations. [1- $\left.\mathrm{C}_{6} \mathrm{H}_{6}\right]\left[\mathrm{BAr}{ }_{4}\right]$ was identified as the major decomposition product ( $50 \%$ ) as well as several other, as yet, unidentified species are also present. These are assumed to be the products of $\mathrm{C}-\mathrm{Cl}$ activation from the solvent, as identified by ESI-MS. 


\section{S.2.3.2. Characterization data for $\left[1-\mathrm{C}_{6} \mathrm{H}_{8}\right]\left[\mathrm{BAr}_{4}^{\mathrm{F}}\right]$}

${ }^{1} \mathrm{H}$ NMR $\left(\mathrm{CD}_{2} \mathrm{Cl}_{2}, 298 \mathrm{~K}, 400 \mathrm{MHz}\right): \delta 7.73$ (s, 8H, ortho-ArH), 7.57 (s, 4H, paraArH), 5.36-5.32 (br m, $5 \mathrm{H}$, alkene $\mathrm{CH}$ and $\mathrm{CDHCl}_{2}$ ), 2.16 (br s, $2 \mathrm{H}$, aliphatic $\mathrm{CH}$ ), 1.94-1.70 (br m, $28 \mathrm{H}$, overlapping aliphatic $\mathrm{CH}$ ), 1.61-1.58 (br m, $2 \mathrm{H}$, aliphatic $\mathrm{CH}$ ), 1.38-1.08 (br m, 16H, overlapping aliphatic $\mathrm{CH}$ ), 0.99-0.96 (br m, 4H, overlapping aliphatic $\mathrm{CH}$ ).

${ }^{1} \mathrm{H}$ NMR $\left(\mathrm{CD}_{2} \mathrm{Cl}_{2}, 183 \mathrm{~K}, 400 \mathrm{MHz}\right): \delta 7.75$ (s, 8H, ortho-ArH), 7.56 (s, 4H, para$\mathrm{ArH}$ ), 5.30-5.23 (br m, 4H, alkene), 2.11 (br s, $2 \mathrm{H}$, aliphatic $\mathrm{CH}$ ), 1.89-1.42 (br m, $30 \mathrm{H}$, overlapping aliphatic $\mathrm{CH}), 1.31-0.74(\mathrm{br} \mathrm{m}, 20 \mathrm{H}$, overlapping aliphatic $\mathrm{CH})$.

${ }^{31} \mathrm{P}\left\{{ }^{1} \mathrm{H}\right\} \operatorname{NMR}\left(\mathrm{CD}_{2} \mathrm{Cl}_{2}, 298 \mathrm{~K}, 162 \mathrm{MHz}\right): \delta 78.7$ (d, JRhP $\left.172 \mathrm{~Hz}\right)$.

${ }^{31} \mathrm{P}\left\{{ }^{1} \mathrm{H}\right\} \operatorname{NMR}\left(\mathrm{CD}_{2} \mathrm{Cl}_{2}, 183 \mathrm{~K}, 162 \mathrm{MHz}\right): \delta 78.6$ (d, J JhP $\left.172 \mathrm{~Hz}\right)$.

${ }^{19} \mathrm{~F}\left\{{ }^{1} \mathrm{H}\right\} \operatorname{NMR}\left(\mathrm{CD}_{2} \mathrm{Cl}_{2}, 298 \mathrm{~K}, 377 \mathrm{MHz}\right): \delta-62.9(\mathrm{~s})$.

${ }^{13} \mathrm{C}\left\{{ }^{1} \mathrm{H}\right\}$ NMR ( $\mathrm{CD}_{2} \mathrm{Cl}_{2}, 298 \mathrm{~K}, 126 \mathrm{MHz}$ ): $\delta 162.2$ (q, J $\mathrm{J}_{\mathrm{CB}} 50 \mathrm{~Hz}$, ipso-ArC), 135.3 (s, ortho-ArC), 129.3 (q, J JF $32 \mathrm{~Hz}$, meta-ArC), 125.1 (q, J JF $272 \mathrm{~Hz}, \mathrm{CF}_{3}$ ), 117.9 (s, para-ArC), $95.0\left(\mathrm{~d}, \mathrm{~J}_{\mathrm{CRh}} 4.4 \mathrm{~Hz}\right.$, alkene- $\left.\mathrm{CH}\right), 82.3(\mathrm{~m}$, alkene- $\mathrm{CH}), 37.9(\mathrm{~m}$, cyclohexyl-CH), 31.3 (s, cyclohexadiene- $\left.\mathrm{CH}_{2}\right), 29.6\left(\mathrm{~m}\right.$, cyclohexyl- $\left.\mathrm{CH}_{2}\right), 29.1$ (s, cyclohexyl- $\mathrm{CH}_{2}$ ), 26.3 (m, PCH${ }_{2}$ ), 22.5 (m, cyclohexyl- $\mathrm{CH}_{2}$ ), 21.1 (s, cyclohexyl- $\mathrm{CH}_{2}$ ). ${ }^{31} \mathrm{P}\left\{{ }^{1} \mathrm{H}\right\}$ SSNMR (162 MHz, $294 \mathrm{~K}, 10 \mathrm{kHz}$ spin rate): $\delta 78.6$ (br m).

${ }^{13} \mathrm{C}\left\{{ }^{1} \mathrm{H}\right\}$ SSNMR (101 MHz, $294 \mathrm{~K}, 10 \mathrm{kHz}$ spin rate): $\delta 163.9$ (ipso-ArC), 133.9 (ortho-ArC), 130.0 (meta-ArC), 124.7 (br, $\mathrm{CF}_{3}$ ), 117.8 (para-ArC), 116.0 (para-ArC), $95.8(\mathrm{C}=\mathrm{C}), 94.1(\mathrm{C}=\mathrm{C}), 83.3(\mathrm{C}=\mathrm{C}), 80.7(\mathrm{C}=\mathrm{C}), 37.7(\mathrm{CH}), 36.0(\mathrm{CH}), 31.4\left(\mathrm{CH}_{2}\right)$, $30.5\left(\mathrm{CH}_{2}\right), 29.5\left(\mathrm{CH}_{2}\right), 26.6\left(\mathrm{CH}_{2}\right), 25.3\left(\mathrm{CH}_{2}\right), 22.0\left(\mathrm{CH}_{2}\right), 21.1\left(\mathrm{CH}_{2}\right), 19.7\left(\mathrm{CH}_{2}\right)$, $18.7\left(\mathrm{CH}_{2}\right)$.

${ }^{1} \mathrm{H}$ projection from ${ }^{1} \mathrm{H} /{ }^{13} \mathrm{C}$ FSLG HETCOR SSNMR (10 kHz spin rate, $294 \mathrm{~K}$ ): $\delta 7.1$ (br), 3.9 (br), 0.5 (br).

ESI-MS found (calc. for $\left.\left[\mathrm{Rh}\left(\mathrm{Cy}_{2} \mathrm{PCH}_{2} \mathrm{CH}_{2} \mathrm{PCy}\right)\left(\mathrm{C}_{6} \mathrm{H}_{8}\right)\right]^{+}\right): \mathrm{m} / z 605.29$ (605.29).

Elemental analysis found (calc. for $\mathrm{C}_{64} \mathrm{H}_{68} \mathrm{BF}_{24} \mathrm{P}_{2} \mathrm{Rh}$ ): $\mathrm{C} 52.32$ (52.33), $\mathrm{H} 4.52$ (4.67). 


\section{S.2.3.3. NMR spectra of $\left[1-\mathrm{C}_{6} \mathrm{H}_{8}\right]\left[B \mathrm{Br}^{\mathrm{F}}{ }_{4}\right]$}

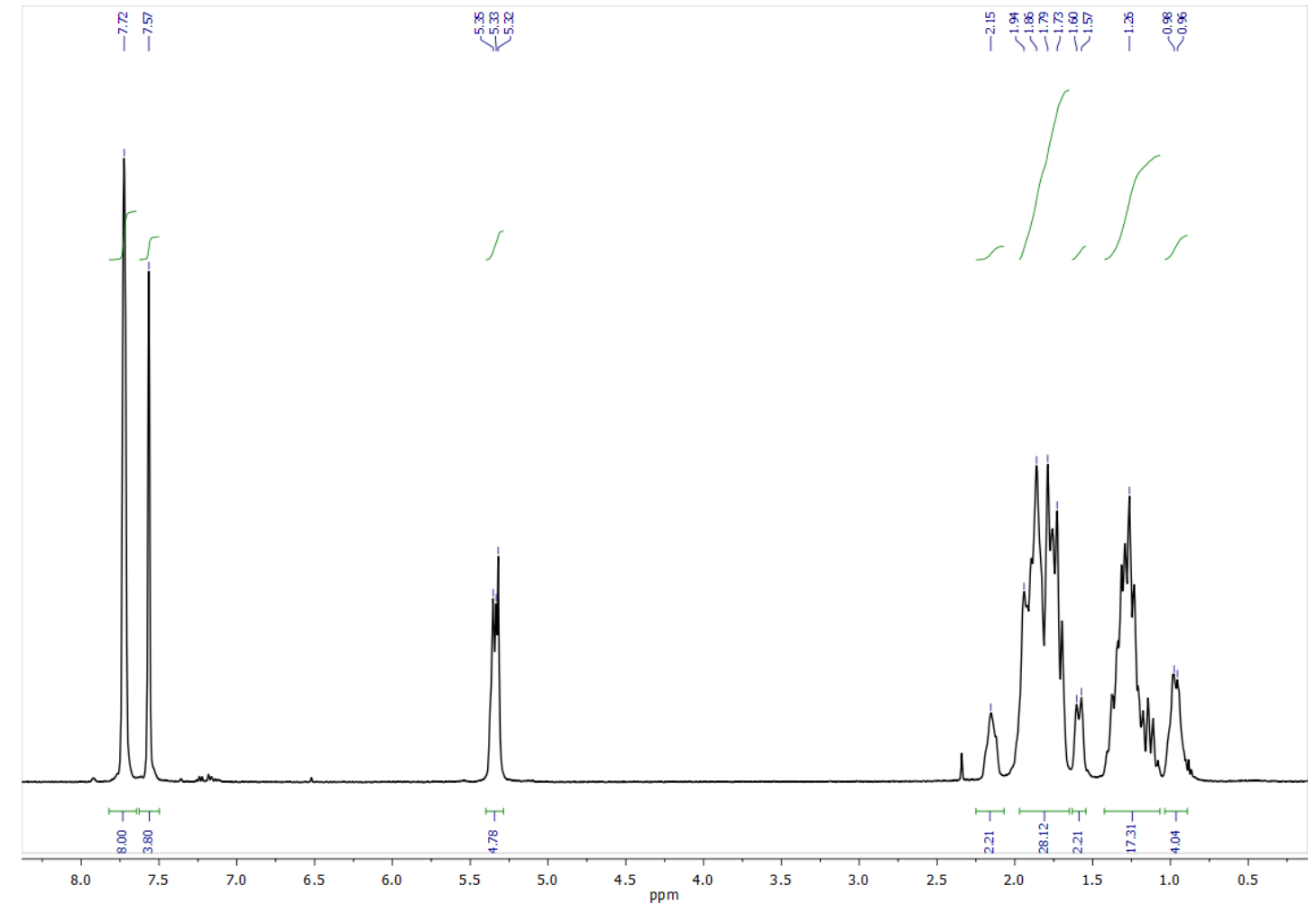

Figure S15: The solution ${ }^{1} \mathrm{H}$ NMR $\left(\mathrm{CD}_{2} \mathrm{Cl}_{2}, 298 \mathrm{~K}, 400 \mathrm{MHz}\right)$ spectrum of [1$\left.\mathrm{C}_{6} \mathrm{H}_{8}\right]\left[\mathrm{BAr}^{\mathrm{F}}{ }_{4}\right]$.

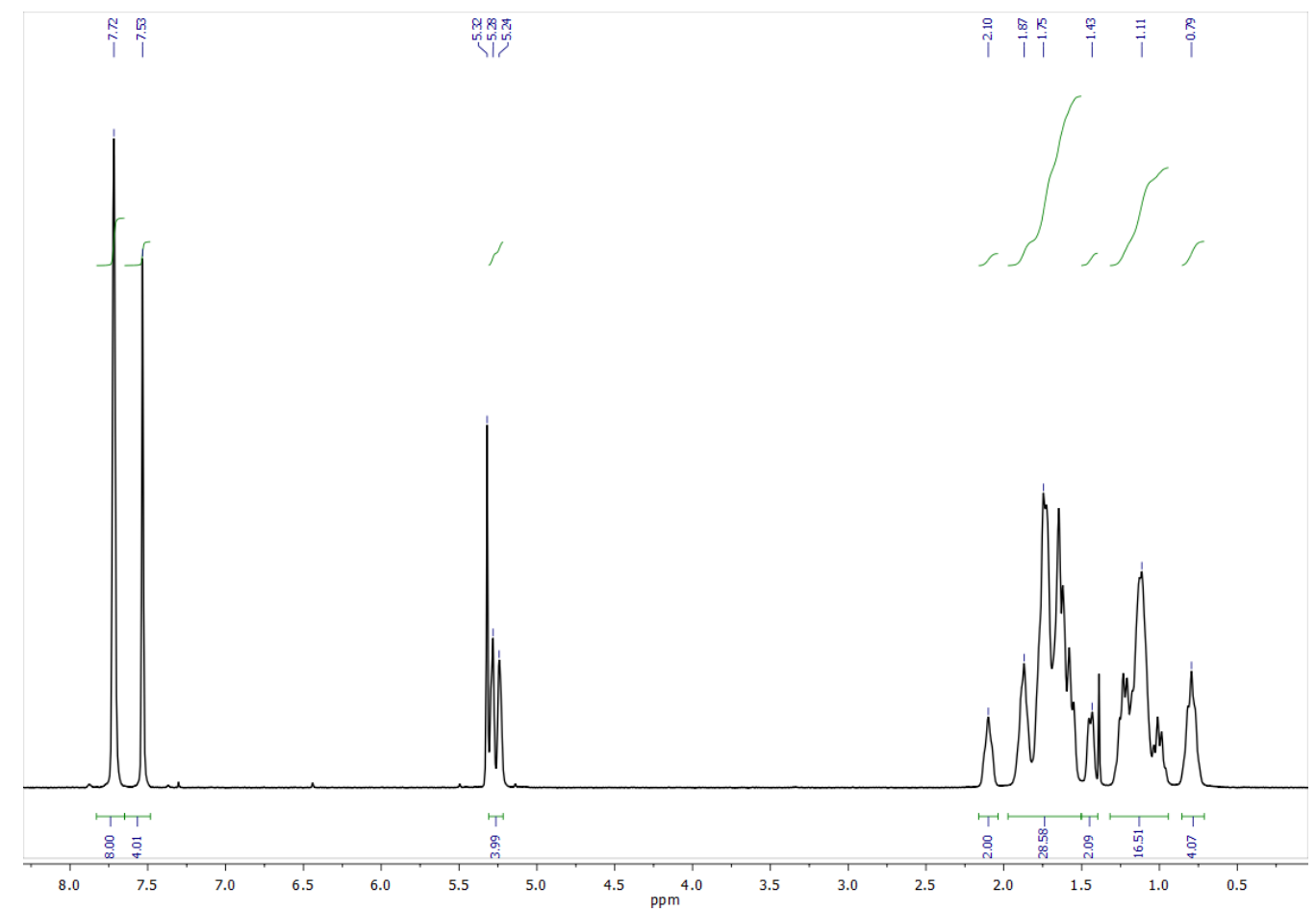

Figure S16: The solution ${ }^{1} \mathrm{H}$ NMR $\left(\mathrm{CD}_{2} \mathrm{Cl}_{2}, 183 \mathrm{~K}, 400 \mathrm{MHz}\right)$ spectrum of [1$\left.\mathrm{C}_{6} \mathrm{H}_{8}\right]\left[\mathrm{BAr}_{4}{ }_{4}\right]$. 


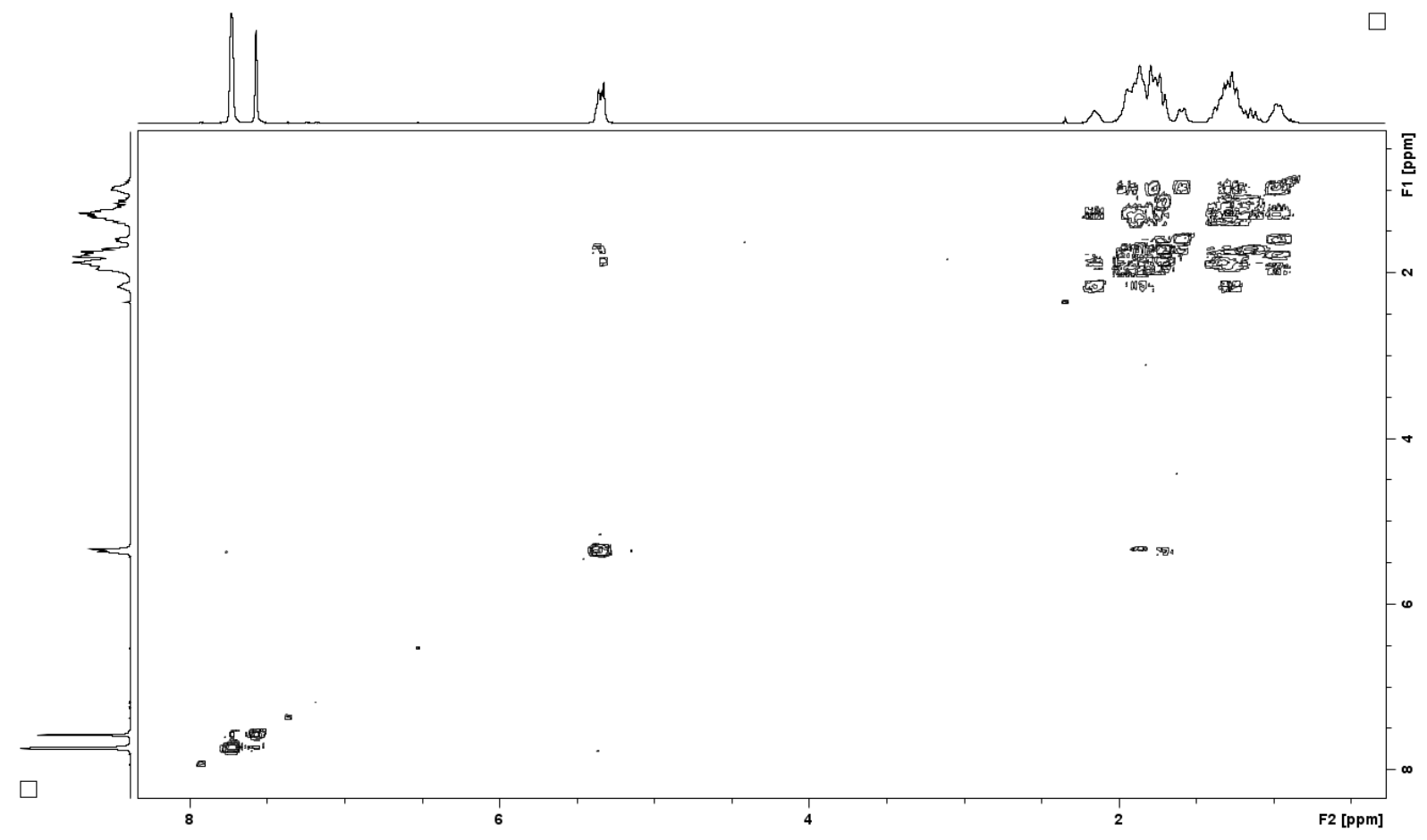

Figure S17: The solution ${ }^{1} \mathrm{H} /{ }^{1} \mathrm{H}$ COSY NMR $\left(\mathrm{CD}_{2} \mathrm{Cl}_{2}, 298 \mathrm{~K}, 400 \mathrm{MHz}\right)$ spectrum of $\left[1-\mathrm{C}_{6} \mathrm{H}_{8}\right]\left[\mathrm{BAr}_{4}{ }_{4}\right]$.

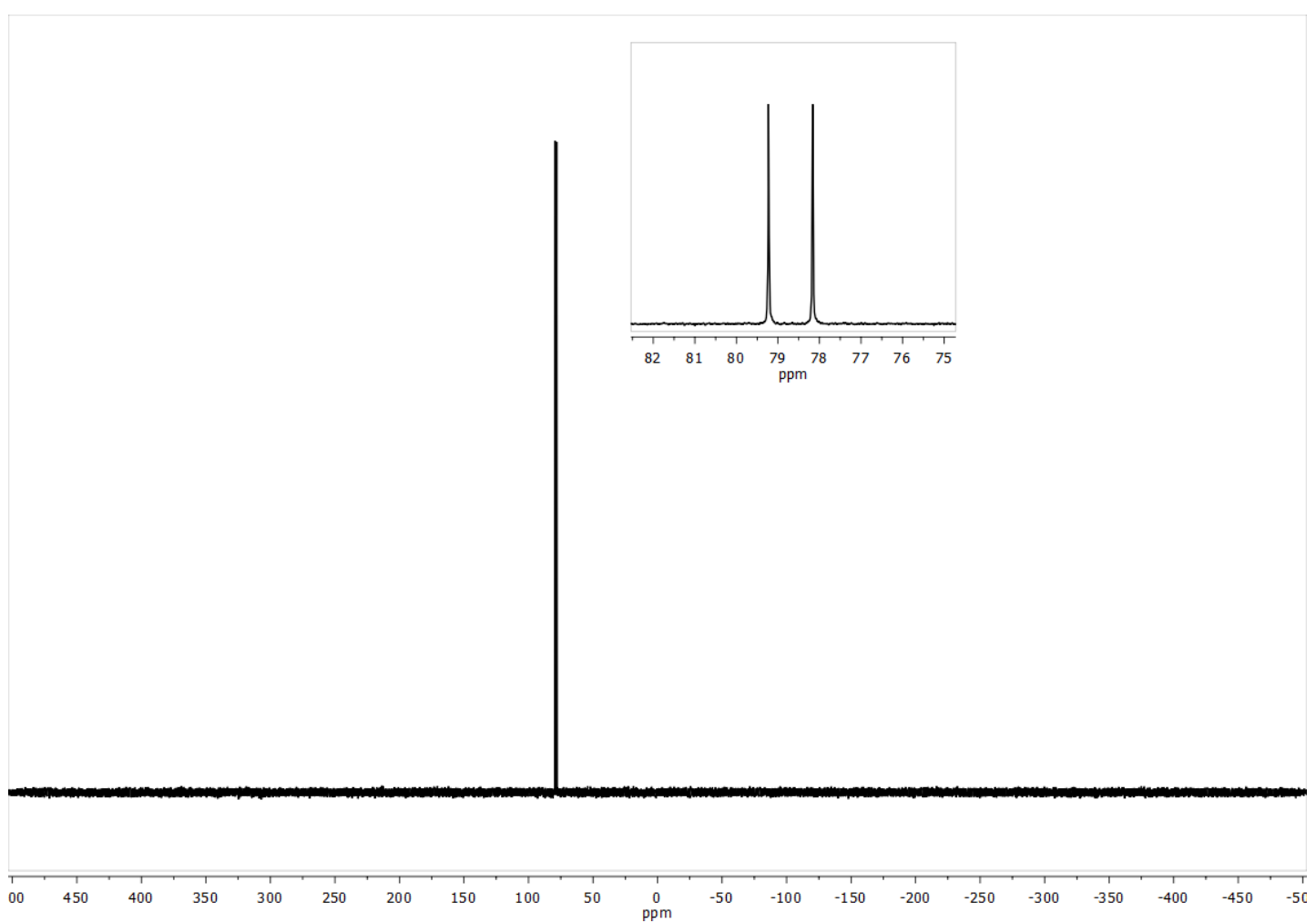

Figure S18: The solution ${ }^{31} \mathrm{P}\left\{{ }^{1} \mathrm{H}\right\} \mathrm{NMR}\left(\mathrm{CD}_{2} \mathrm{Cl}_{2}, 298 \mathrm{~K}, 162 \mathrm{MHz}\right)$ spectrum of [1$\left.\mathrm{C}_{6} \mathrm{H}_{8}\right]\left[\mathrm{BAr}_{4}{ }_{4}\right.$. 


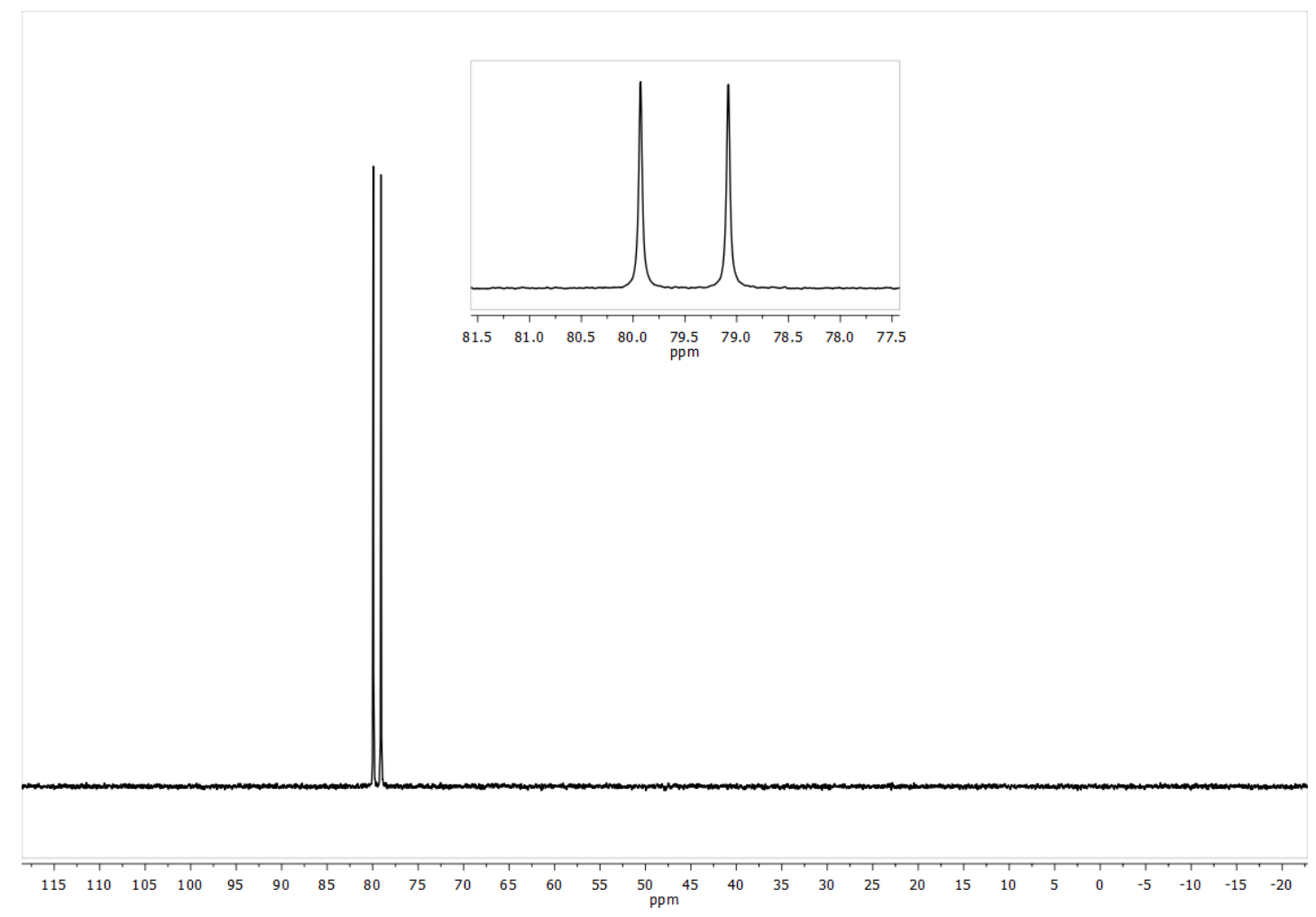

Figure S19: The solution ${ }^{31} \mathrm{P}\left\{{ }^{1} \mathrm{H}\right\} \mathrm{NMR}\left(\mathrm{CD}_{2} \mathrm{Cl}_{2}, 183 \mathrm{~K}, 162 \mathrm{MHz}\right)$ spectrum of [1$\left.\mathrm{C}_{6} \mathrm{H}_{8}\right]\left[\mathrm{BAr}_{4}{ }_{4}\right.$.

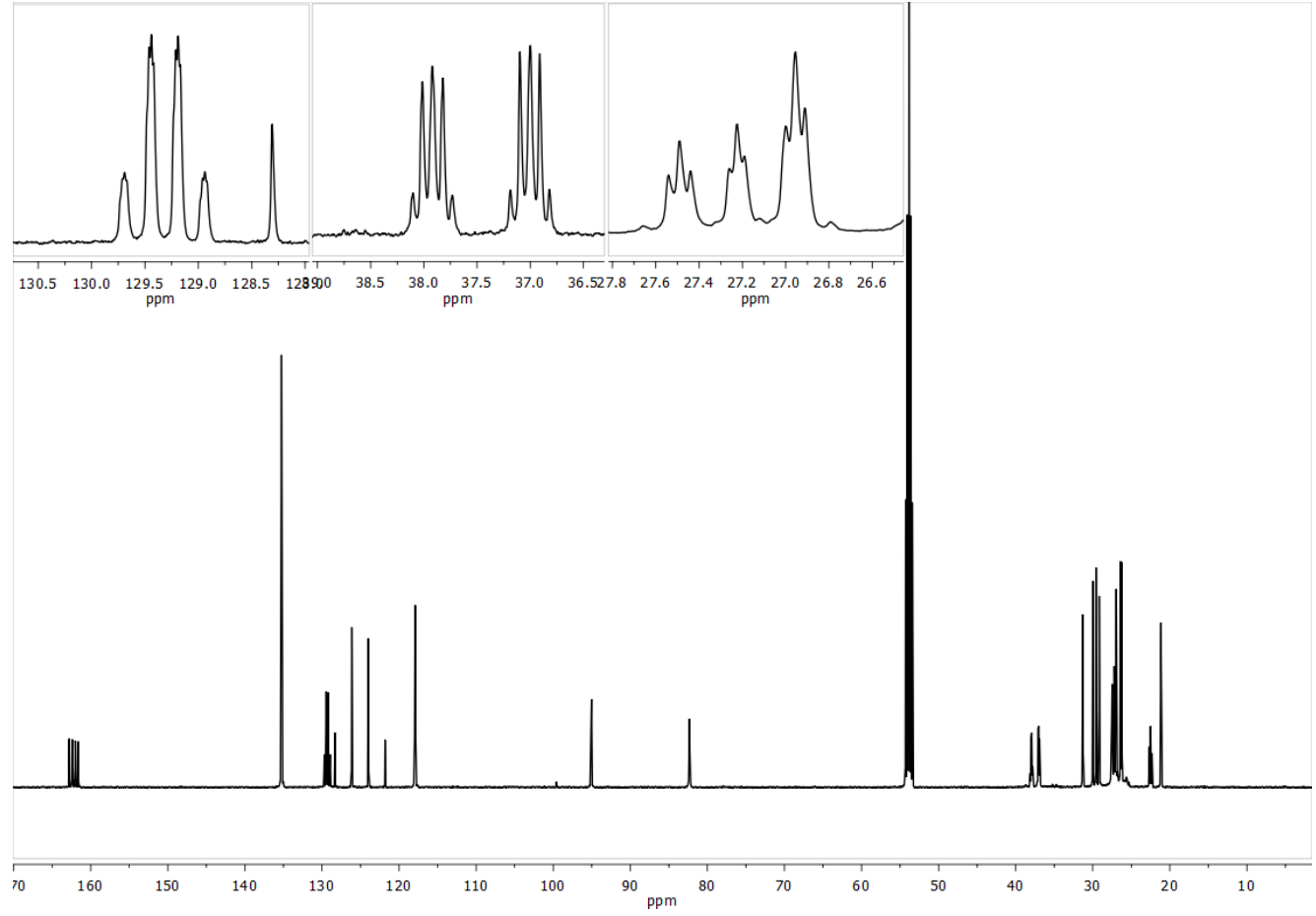

Figure S20: The solution ${ }^{13} \mathrm{C}\left\{{ }^{1} \mathrm{H}\right\} \mathrm{NMR}\left(\mathrm{CD}_{2} \mathrm{Cl}_{2}, 298 \mathrm{~K}, 126 \mathrm{MHz}\right)$ spectrum of [1$\left.\mathrm{C}_{6} \mathrm{H}_{8}\right]\left[\mathrm{BAr}_{4}{ }^{\mathrm{C}}\right.$. 


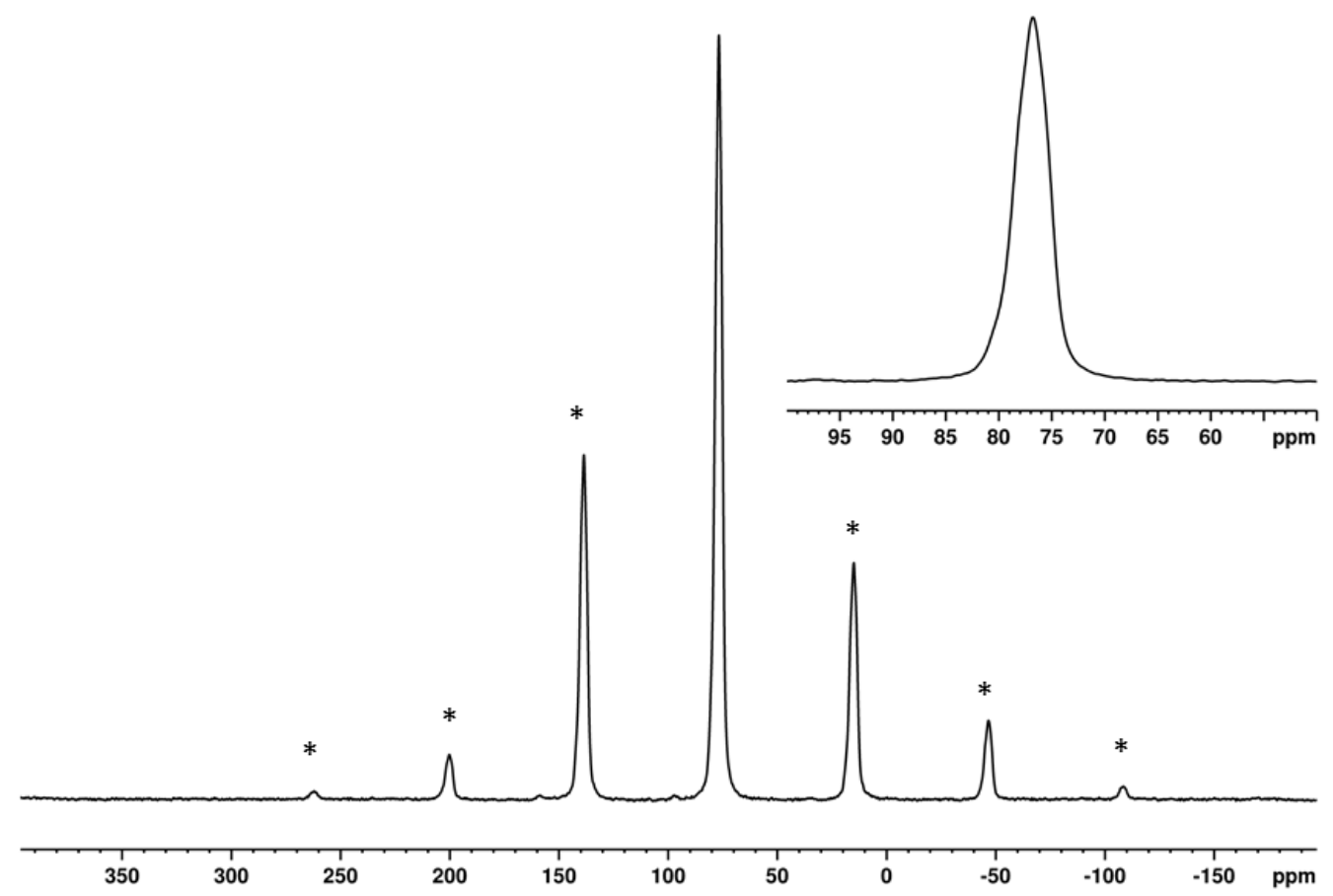

Figure S21: The ${ }^{31} \mathrm{P}\left\{{ }^{1} \mathrm{H}\right\}$ SSNMR (162 MHz, $294 \mathrm{~K}, 10 \mathrm{kHz}$ spin rate) spectrum of $\left[1-\mathrm{C}_{6} \mathrm{H}_{8}\right]\left[\mathrm{BAr}{ }_{4}\right]$. The resonances marked ${ }^{*}$ are due to spinning sidebands. The inset is an enlargement of the central resonance.

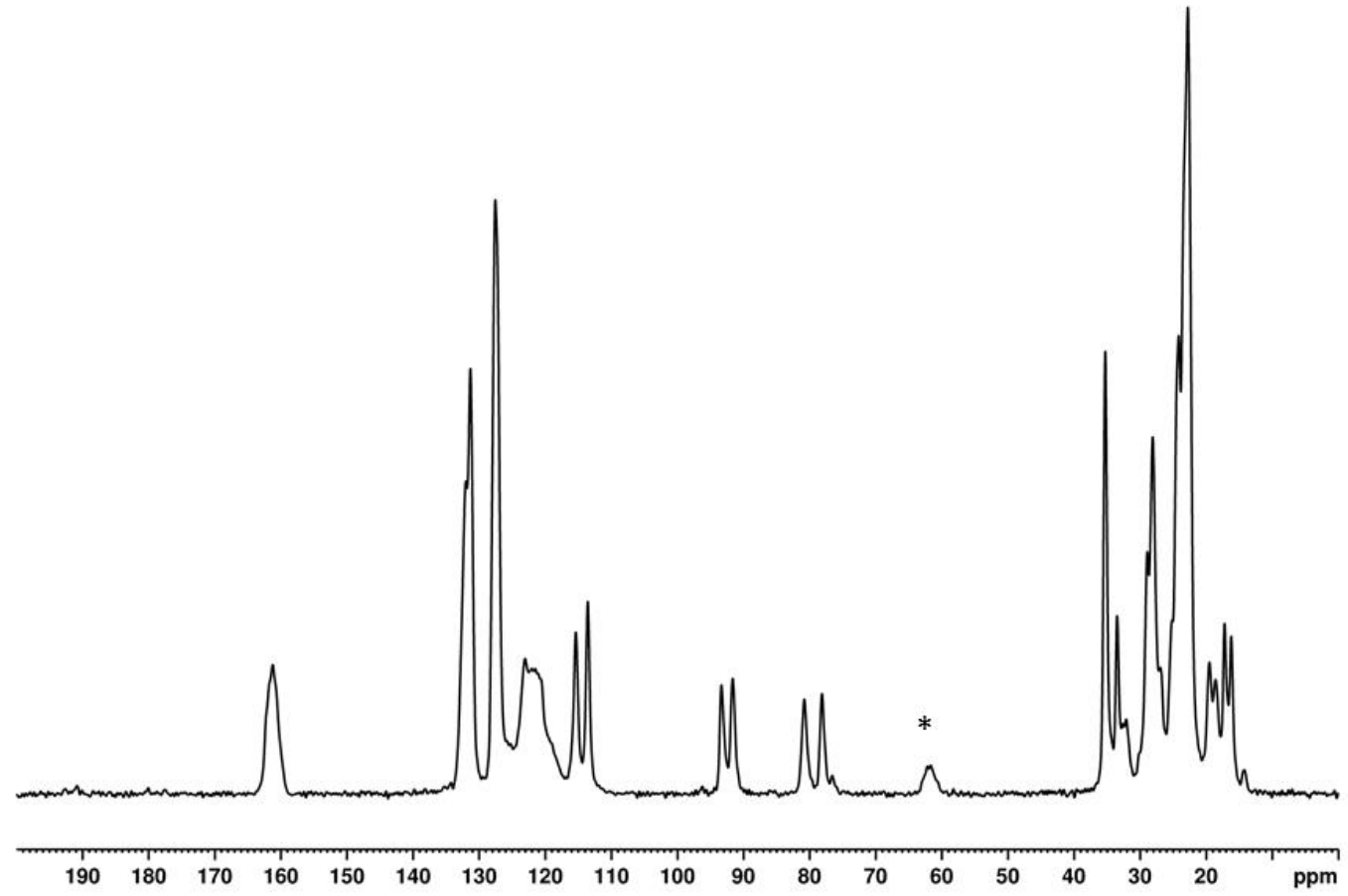

Figure S22: The ${ }^{13} \mathrm{C}\left\{{ }^{1} \mathrm{H}\right\}$ SSNMR (101 MHz, $294 \mathrm{~K}, 10 \mathrm{kHz}$ spin rate) spectrum of $\left[1-\mathrm{C}_{6} \mathrm{H}_{8}\right]\left[\mathrm{BAr}{ }_{4}{ }_{4}\right.$. The resonance marked * is due to spinning sidebands. 


\section{S.2.4. $\left[\mathrm{Rh}\left(\mathrm{Cy}_{2} \mathrm{PCH}_{2} \mathrm{CH}_{2} \mathrm{PCy}_{2}\right)\left(\mathrm{C}_{6} \mathrm{H}_{12}\right)\right]\left[B \mathrm{Br}_{4}^{\mathrm{F}}\right],\left[1-\mathrm{C}_{6} \mathrm{H}_{12}\right]\left[\mathrm{BAr}{ }_{4}\right]$}

\section{S.2.4.1. Synthesis of $\left[1-\mathrm{C}_{6} \mathrm{H}_{12}\right]\left[B \mathrm{Br}_{4}{ }_{4}\right]$ for an $\mathrm{x}$-ray diffraction study}<smiles>C1CCC(P2CCCC2)C1</smiles>

[1- $\left.\mathrm{C}_{6} \mathrm{H}_{8}\right]\left[\mathrm{BAr}_{4}{ }^{\mathrm{F}}\right]$

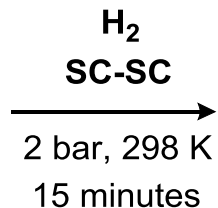

15 minutes

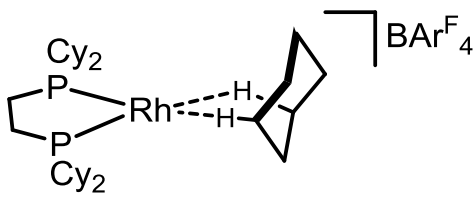

$\left[1-\mathrm{C}_{6} \mathrm{H}_{12}\right]\left[\mathrm{BAr}_{4}\right]$

Deep red crystals of $\left[1-\mathbf{C}_{6} \mathrm{H}_{8}\right]\left[\mathrm{BAr}_{4}{ }_{4}\right]$ were treated with $\mathrm{H}_{2}$ (2 bar, $298 \mathrm{~K}, 15$ mins) inside a J Young flask. The colour of the crystals immediately darkens to a burgundy color. The crystalline material was then coated with Fomblin® ${ }^{\circledR}$ oil under an argon flush, a suitable crystal was rapidly selected and then transferred to the Cryostream of a diffractometer and an x-ray diffraction study was undertaken. For further of the structural study, please refer to section S.5.

After 90 minutes under hydrogen, approx. $10 \%$ of the sample has decomposed. This was shown by ${ }^{31} \mathrm{P}\left\{{ }^{1} \mathrm{H}\right\}$ SSNMR, see section S.2.4.6, figure S34. 


\section{S.2.4.2. Synthesis of $\left[1-\mathrm{C}_{6} \mathrm{H}_{12}\right]\left[B \mathrm{Br}_{4}{ }_{4}\right]$ for SSNMR characterization}

A powdered microcrystalline sample of $\left[1-\mathbf{C}_{6} \mathbf{H}_{8}\right]\left[\mathrm{BAr}_{4}\right](35 \mathrm{mg})$ was packed in a 3.2 $\mathrm{mm}$ SSNMR rotor, inside an argon filled glove box. The rotor was then placed in a custom built glass $\mathrm{J}$ Young flask ${ }^{\mathrm{S7}}$ and the sample was then exposed to $\mathrm{H}_{2}$ (1 bar, $298 \mathrm{~K}$ ). After 20 minutes, the rotor cap was fitted under a flush of $\mathrm{H}_{2}$. The sample was immediately transferred to the bore of a pre-cooled (158 K) SSNMR spectrometer ( 10 mins) and analyzed ${ }^{31} \mathrm{P}\left\{{ }^{1} \mathrm{H}\right\}$ and ${ }^{13} \mathrm{C}\left\{{ }^{1} \mathrm{H}\right\}$ solid state NMR spectroscopy.

These conditions were optimized to form $\left[1-\mathrm{C}_{6} \mathrm{H}_{12}\right]\left[\mathrm{BAr}{ }_{4}\right]$. At $158 \mathrm{~K}$, no onward reactivity with $\mathrm{H}_{2}$ is observed. When $\mathrm{H}_{2}$ replaced by argon at $298 \mathrm{~K}$, as so the rotor is packed under an argon atmosphere, spontaneous dehydrogenation is observed before cooling to $158 \mathrm{~K}$, to form [1- $\left.\mathrm{C}_{6} \mathrm{H}_{10}\right]\left[\mathrm{BAr}{ }_{4}^{\mathrm{F}}\right.$, see section S.4.4.1.

\section{S.2.4.3. Characterization data for $\left[1-\mathrm{C}_{6} \mathrm{H}_{12}\right]\left[B \mathrm{Brr}_{4}{ }_{4}\right]$}

${ }^{31} \mathrm{P}\left\{{ }^{1} \mathrm{H}\right\}$ SSNMR (162 MHz, $294 \mathrm{~K}, 10 \mathrm{kHz}$ spin rate): $\delta 108.4$ (two overlapping doublets, $J_{\mathrm{RhP}}=\sim 220 \mathrm{~Hz}$.

${ }^{31} \mathrm{P}\left\{{ }^{1} \mathrm{H}\right\}$ SSNMR (162 MHz, $158 \mathrm{~K}, 10 \mathrm{kHz}$ spin rate): $\delta 107.1$ (br), 104.5 (br).

${ }^{13} \mathrm{C}\left\{{ }^{1} \mathrm{H}\right\}$ SSNMR $(101 \mathrm{MHz}, 198 \mathrm{~K}, 10 \mathrm{kHz}$ spin rate): $\delta 161.1(\operatorname{ArC}), 131.8(\operatorname{ArC})$, $127.2(\mathrm{ArC}), 121.8\left(\mathrm{br}, \mathrm{CF}_{3}\right), 115.2(\mathrm{ArC}), 112.7(\operatorname{ArC}), 34.4,32.4,28.9,27.8,25.8$, 24.2, 22.8, 22.3, 21.6, 17.2 (multiple aliphatic resonances).

${ }^{13} \mathrm{C}\left\{{ }^{1} \mathrm{H}\right\}$ SSNMR (101 MHz, $158 \mathrm{~K}, 10 \mathrm{kHz}$ spin rate): $\delta 161.1(\operatorname{ArC}), 131.8(\operatorname{ArC})$, 127.1 (ArC), 121.6 (br, $\mathrm{CF}_{3}$ ), 115.1 (ArC), 112.5 (ArC), 34.0, 32.1, 27.8, 24.1, 22.7, 19.7, 16.5 (multiple aliphatic resonances).

${ }^{1} \mathrm{H}$ projection from ${ }^{1} \mathrm{H} /{ }^{13} \mathrm{C}$ FSLG HETCOR SSNMR (198 K, $10 \mathrm{kHz}$ spin rate): $\delta 7.1$ (br), $1.0(\mathrm{br})$.

${ }^{1} \mathrm{H}$ projection from ${ }^{1} \mathrm{H} /{ }^{13} \mathrm{C}$ FSLG HETCOR SSNMR (158 K, $10 \mathrm{kHz}$ spin rate): $\delta 7.1$ (br), 1.0 (br), -1.6 (br). 


\section{S.2.4.4. NMR spectra of $\left[1-\mathrm{C}_{6} \mathrm{H}_{12}\right]\left[B \mathrm{Br}_{4}\right]$}

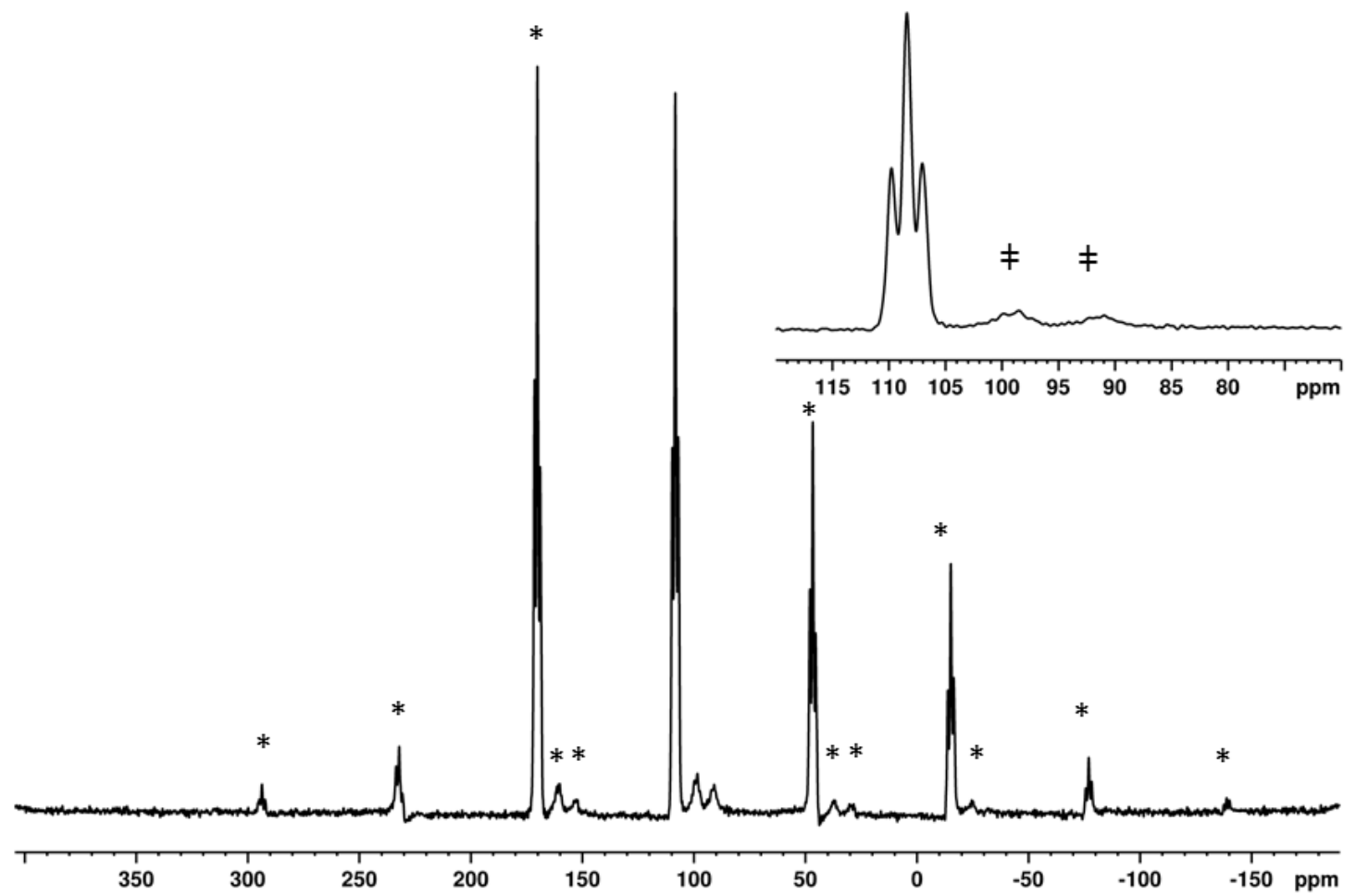

Figure S23: The ${ }^{31} \mathrm{P}\left\{{ }^{1} \mathrm{H}\right\}$ SSNMR (162 MHz, $298 \mathrm{~K}, 10 \mathrm{kHz}$ spin rate) spectrum of [1- $\left.\mathrm{C}_{6} \mathrm{H}_{12}\right]\left[\mathrm{BAr}_{4}{ }_{4}\right]$ prepared in situ, packed under at atmosphere of $\mathrm{H}_{2}$. The resonances marked $\neq$ are assigned to $\left[1-\mathrm{C}_{6} \mathrm{H}_{10}\right]\left[\mathrm{BAr}_{4}{ }_{4}\right]$ which has formed by partial dehydrogenation, see section S.4.3. The resonances marked * are due to spinning sidebands. The inset is an enlargement of the central resonances. 


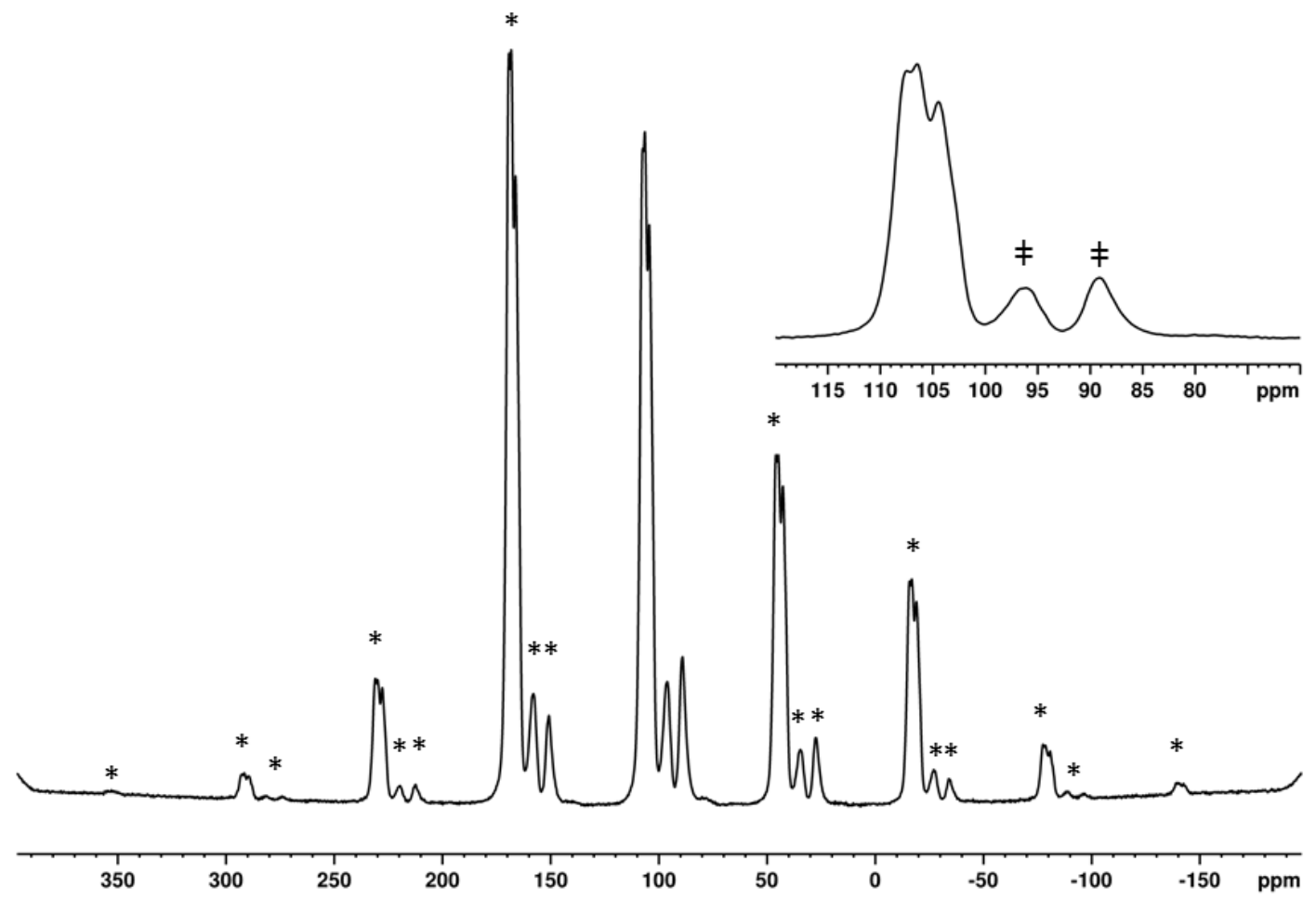

Figure S24: The ${ }^{31} \mathrm{P}\left\{{ }^{1} \mathrm{H}\right\}$ SSNMR (162 MHz, $158 \mathrm{~K}, 10 \mathrm{kHz}$ spin rate) spectrum of [1- $\left.\mathrm{C}_{6} \mathrm{H}_{12}\right]\left[\mathrm{BAr} \mathrm{F}_{4}\right]$ prepared in situ. The resonances marked $\neq$ are assigned to [1$\left.\mathrm{C}_{6} \mathrm{H}_{10}\right]\left[B A \mathrm{rr}_{4}{ }_{4}\right]$ which has formed by partial dehydrogenation. The resonances marked * are due to spinning sidebands. The inset is an enlargement of the central resonances. This spectrum was obtained from a different sample to that above, resulting in a different degree of dehydrogenation. 


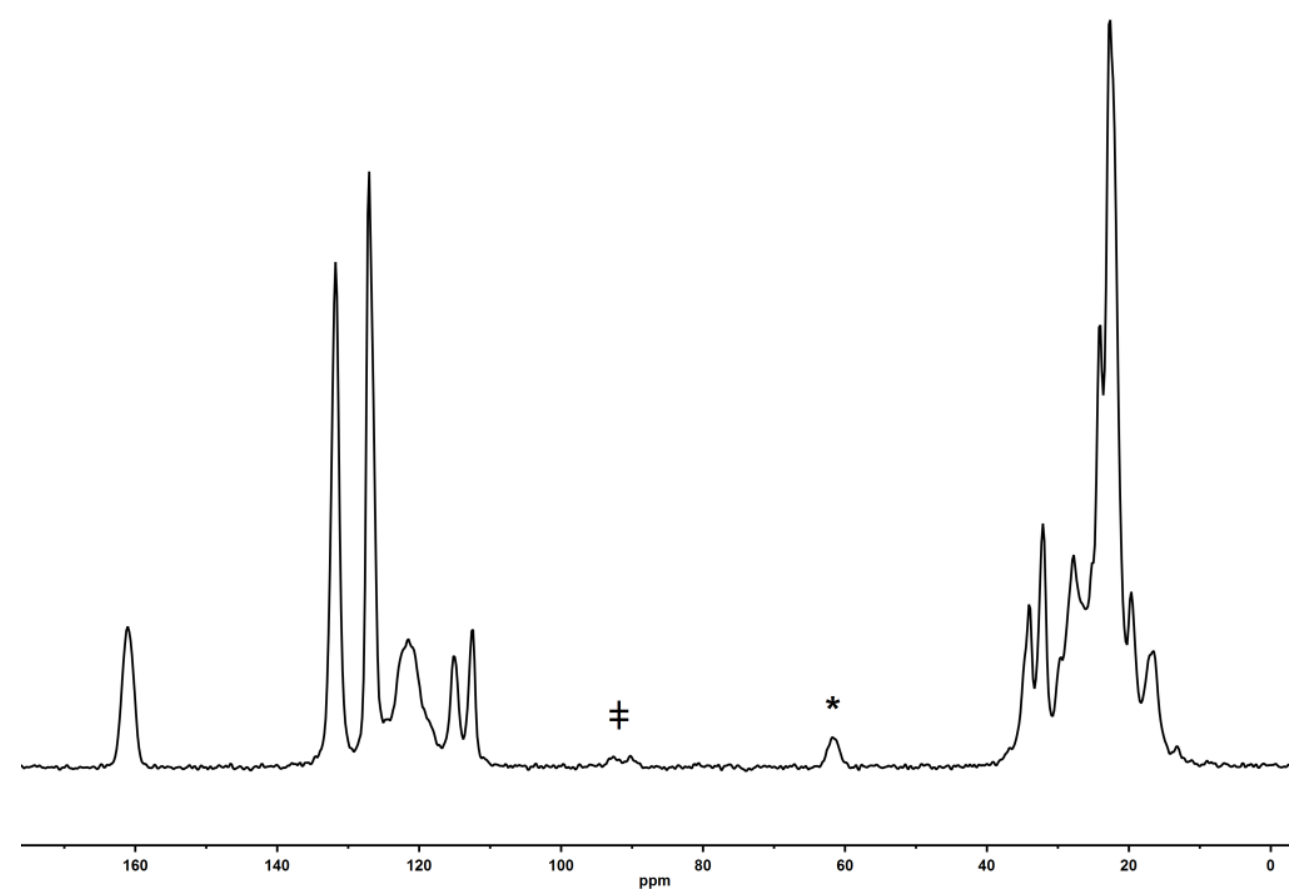

Figure S25: The ${ }^{13} \mathrm{C}\left\{{ }^{1} \mathrm{H}\right\}$ SSNMR (100 MHz, $158 \mathrm{~K}, 10 \mathrm{kHz}$ spin rate) spectrum of [1- $\mathrm{C}_{6} \mathrm{H}_{12}$ ] $\left[\mathrm{BAr}_{4}^{\mathrm{F}}\right.$ ] prepared in situ. The resonances marked $\neq$ are assigned to [1$\left.\mathrm{C}_{6} \mathrm{H}_{10}\right]\left[\mathrm{BAr}{ }_{4}{ }_{4}\right.$ which formed by partial dehydrogenation. The resonance marked ${ }^{*}$ is due to a spinning sideband.

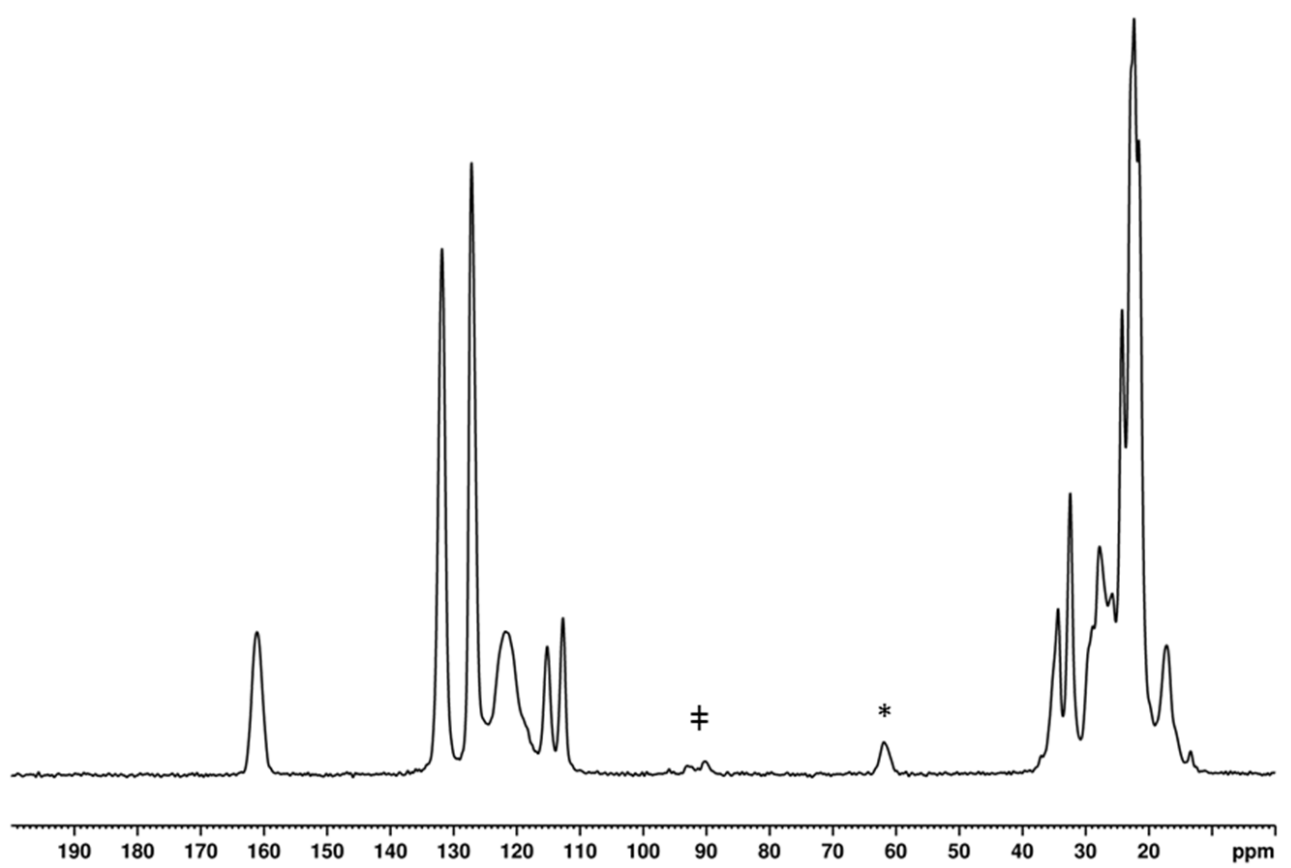

Figure S26: The ${ }^{13} \mathrm{C}\left\{{ }^{1} \mathrm{H}\right\}$ SSNMR (100 MHz, $198 \mathrm{~K}, 10 \mathrm{kHz}$ spin rate) spectrum of $\left[1-\mathrm{C}_{6} \mathrm{H}_{12}\right]\left[\mathrm{BAr}_{4}{ }_{4}\right]$ prepared in situ. The resonances marked $\neq$ are assigned to [1$\left.\mathrm{C}_{6} \mathrm{H}_{10}\right]\left[B \mathrm{Br}_{4}{ }_{4}\right.$, which formed by partial dehydrogenation. The resonance marked * is due to a spinning sideband. 


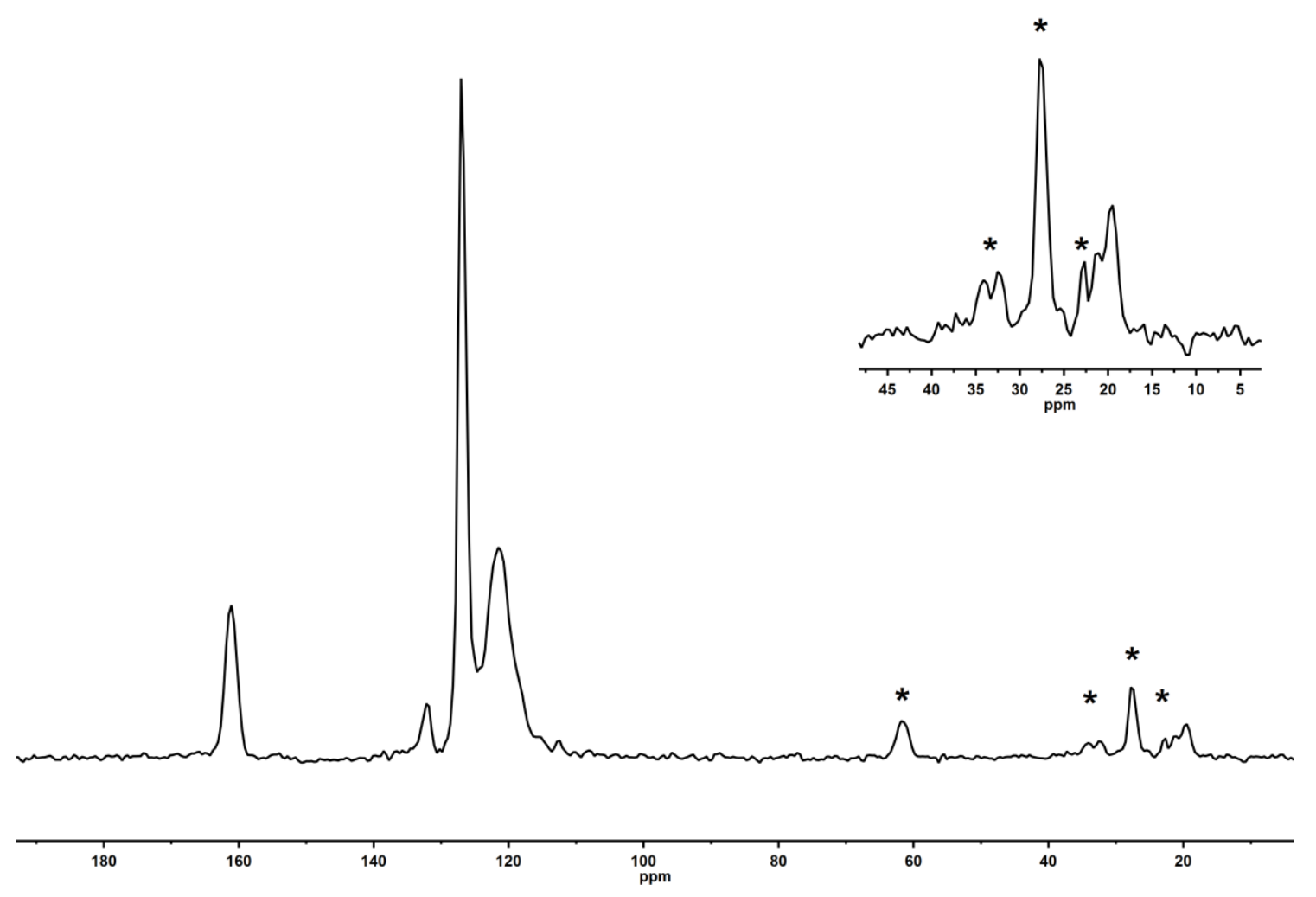

Figure S27: The ${ }^{13} \mathrm{C}\left\{{ }^{1} \mathrm{H}\right\}$ NQS SSNMR $(100 \mathrm{MHz}, 158 \mathrm{~K}, 10 \mathrm{kHz}$ spin rate) spectrum of [1- $\left.\mathrm{C}_{6} \mathrm{H}_{12}\right]\left[\mathrm{BAr}{ }_{4}{ }_{4}\right]$ prepared in situ. The resonances marked ${ }^{*}$ are due to spinning sidebands.

The inset is an enlargement of the resonances between $\delta 45$ to 5 , showing two peaks at $\delta 19.7$ and 21.4. These peaks did not shift position in the analogous $8 \mathrm{kHz}$ NQS SSNMR spectrum, suggestive of real signals and not sidebands. 


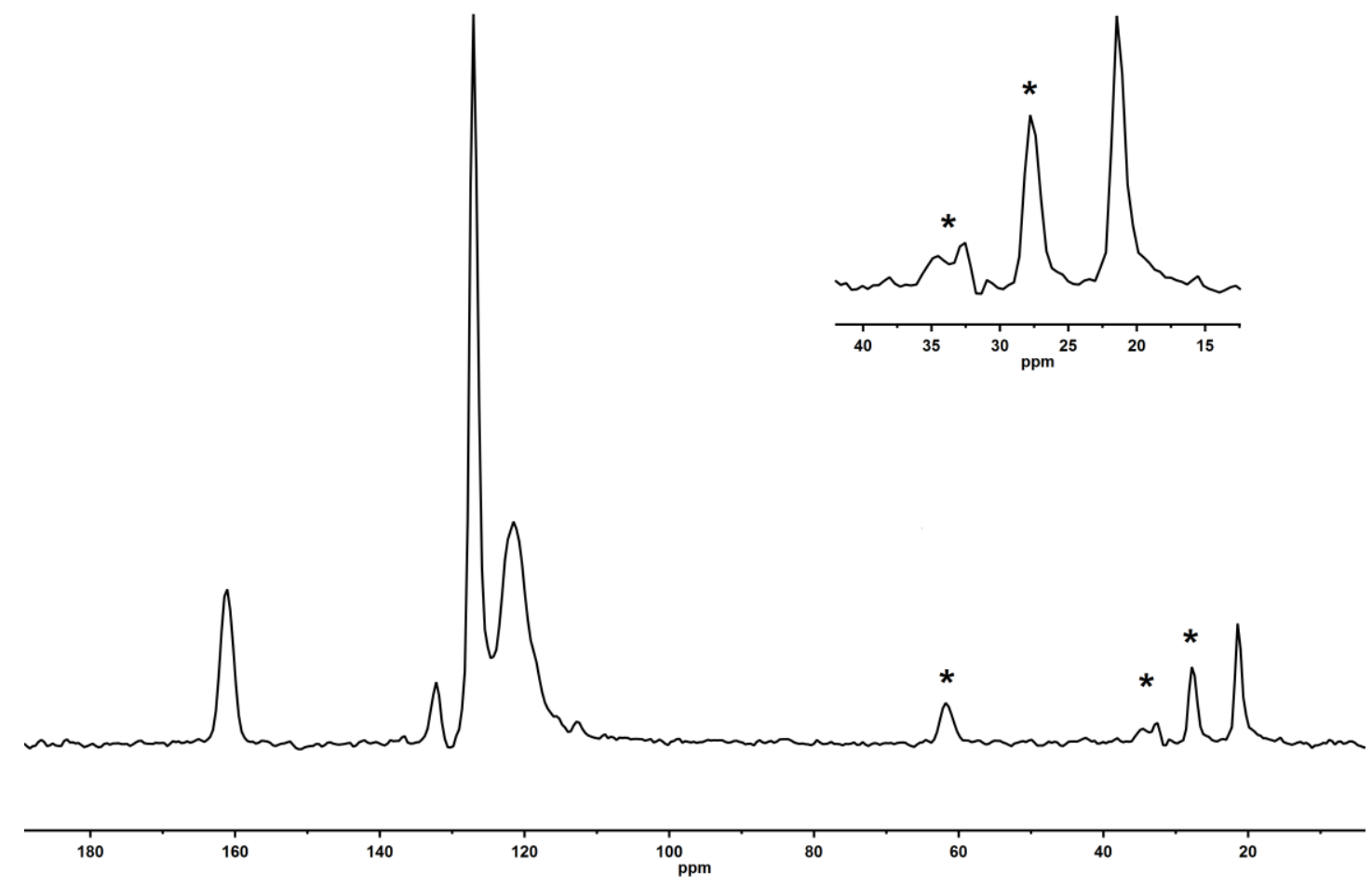

Figure S28: The ${ }^{13} \mathrm{C}\left\{{ }^{1} \mathrm{H}\right\}$ NQS SSNMR $(100 \mathrm{MHz}, 198 \mathrm{~K}, 10 \mathrm{kHz}$ spin rate) spectrum of [1- $\left.\mathrm{C}_{6} \mathrm{H}_{12}\right]\left[\mathrm{BAr}{ }_{4}\right]$ prepared in situ. The resonances marked * are due to spinning sidebands.

The inset is an enlargement of the resonances at $\delta 45$ to 15 , showing only a single resonance at $\delta 21.4$. This peak did not shift position in the analogous $8 \mathrm{kHz} N Q S$ SSNMR spectrum, suggestive of a real signal and not a sideband. 


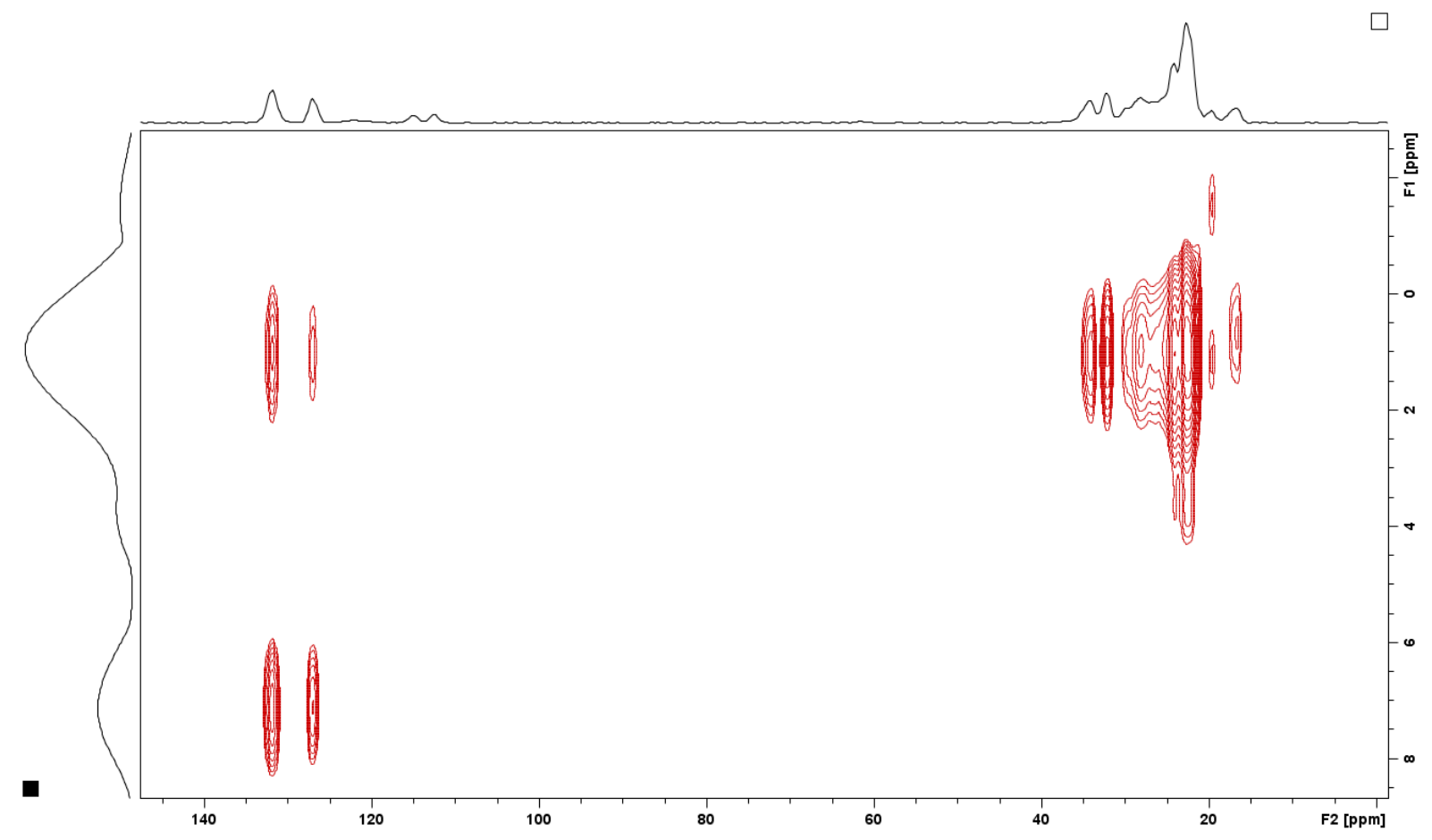

Figure S29: The ${ }^{1} \mathrm{H} /{ }^{13} \mathrm{C}$ FSLG HETCOR SSNMR (158 K, $10 \mathrm{kHz}$ spin rate) spectrum of [1- $\left.\mathrm{C}_{6} \mathrm{H}_{12}\right]\left[\mathrm{BAr}^{\mathrm{F}}\right]$ prepared in situ.

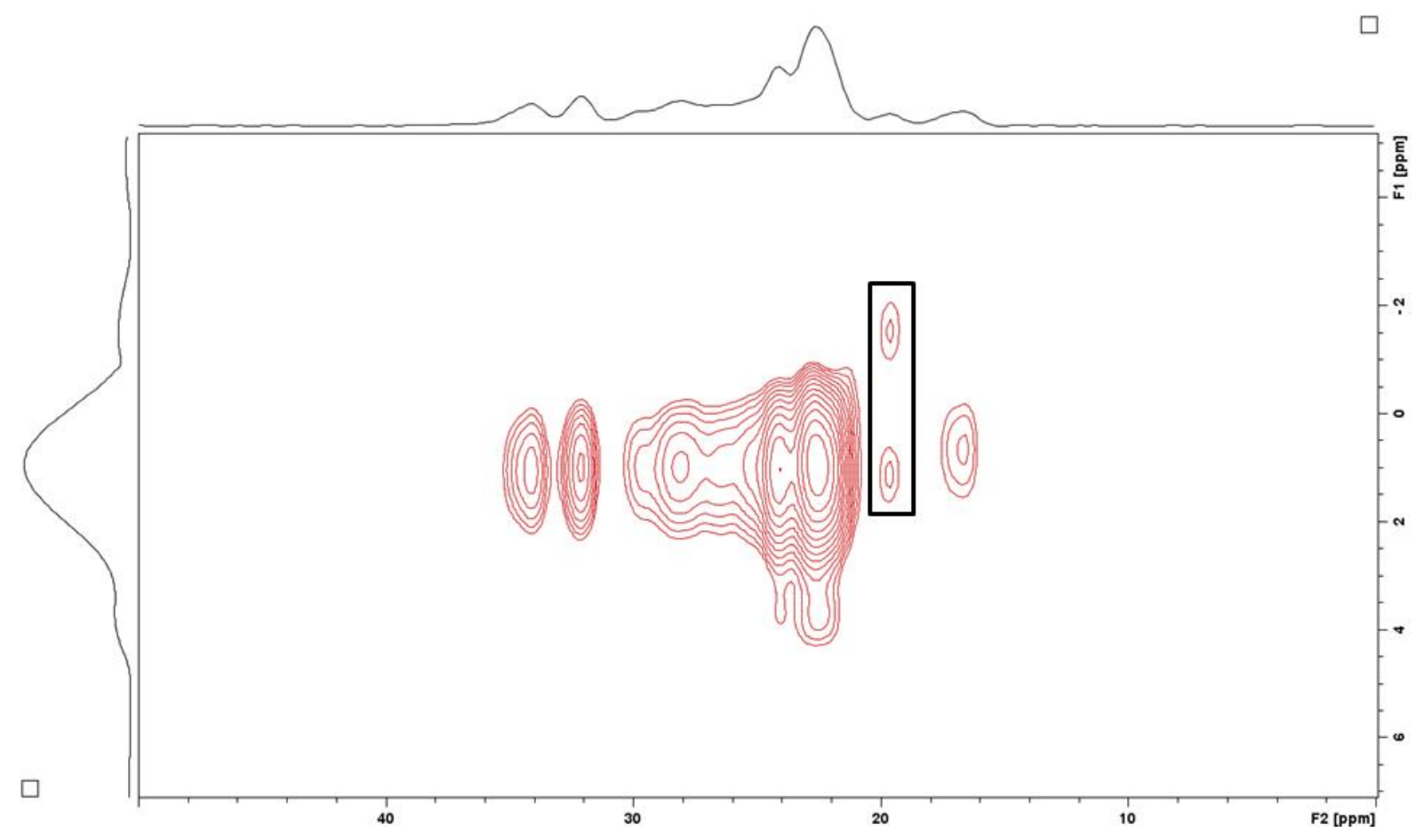

Figure S30: The ${ }^{1} \mathrm{H} /{ }^{13} \mathrm{C}$ FSLG HETCOR SSNMR ( $158 \mathrm{~K}, 10 \mathrm{kHz}$ spin rate) spectrum

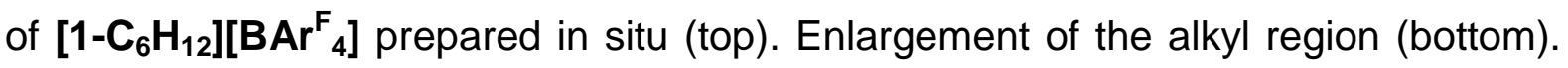
Black box added to guide the eye. 


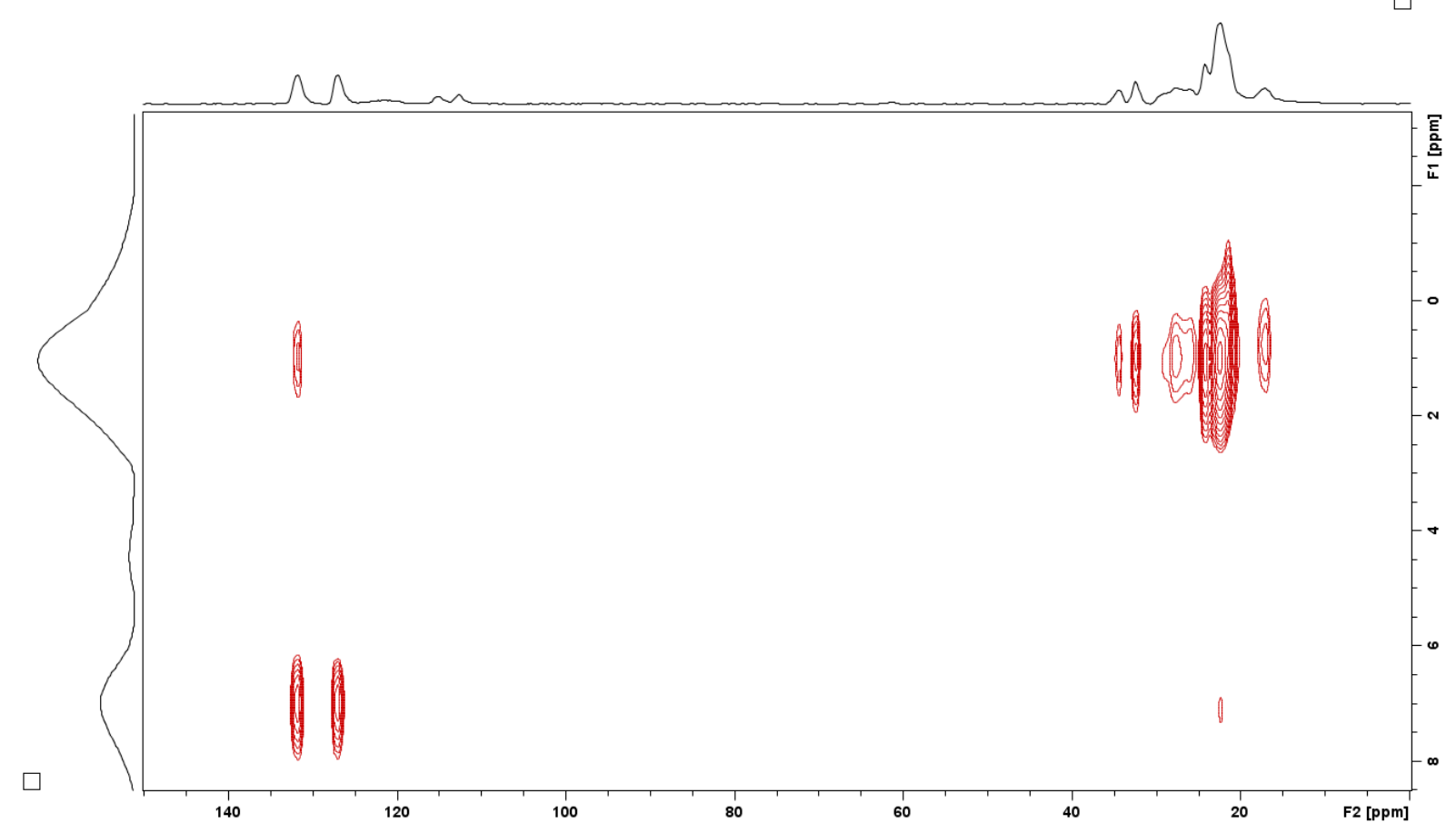

Figure S31: The ${ }^{1} \mathrm{H} /{ }^{13} \mathrm{C}$ FSLG HETCOR SSNMR (198 K, $10 \mathrm{kHz}$ spin rate) spectrum of [1- $\left.\mathrm{C}_{6} \mathrm{H}_{12}\right]\left[\mathrm{BAr}^{\mathrm{F}}\right]$ prepared in situ.

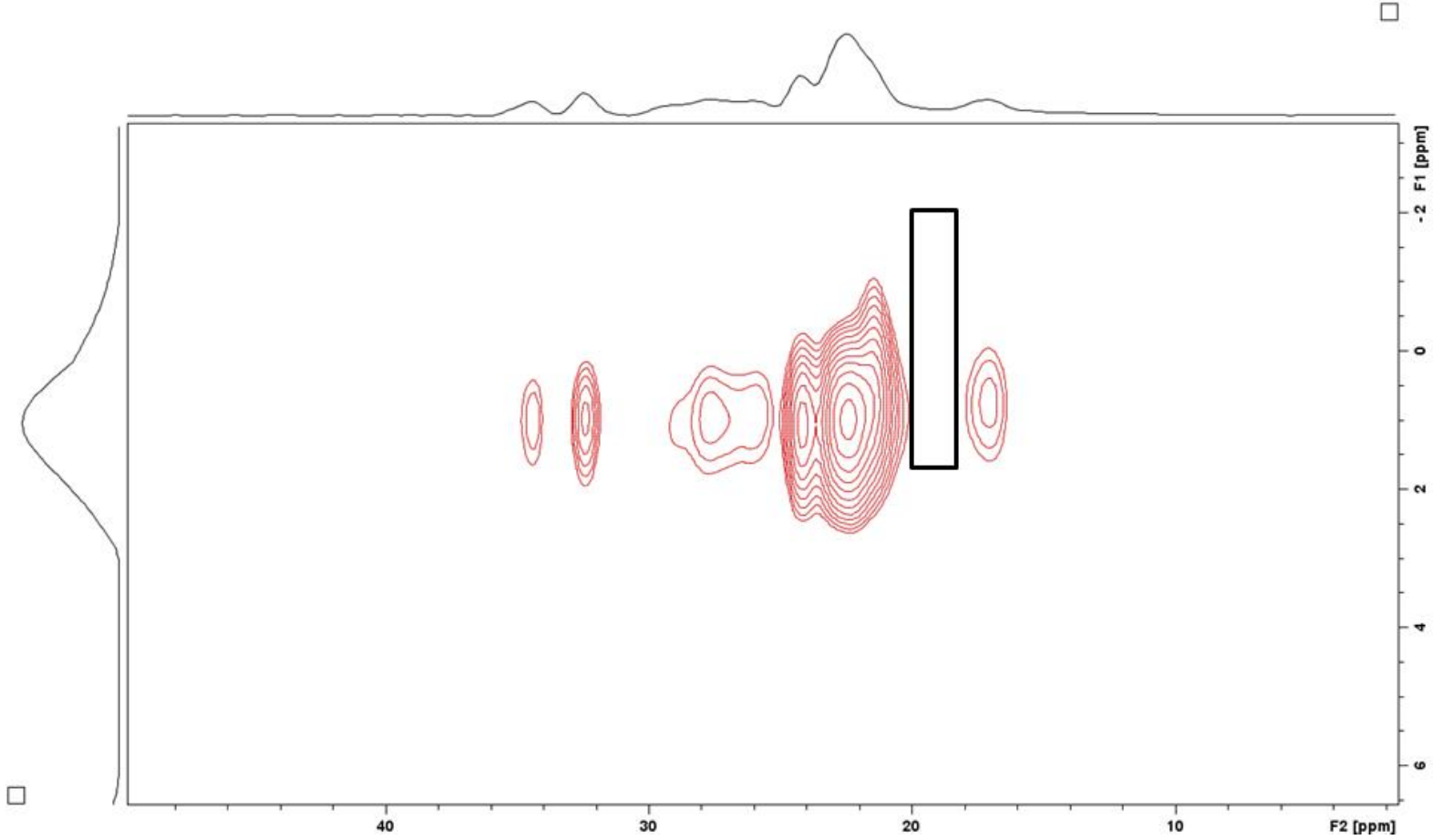

Figure S32: The ${ }^{1} \mathrm{H} /{ }^{13} \mathrm{C}$ FSLG HETCOR SSNMR (198 K, $10 \mathrm{kHz}$ spin rate) spectrum of [1- $\left.\mathbf{C}_{6} \mathrm{H}_{12}\right]\left[B A r^{F_{4}}\right.$ ] prepared in situ (top). Enlargement of the alkyl region (bottom). Black box added to guide the eye. 


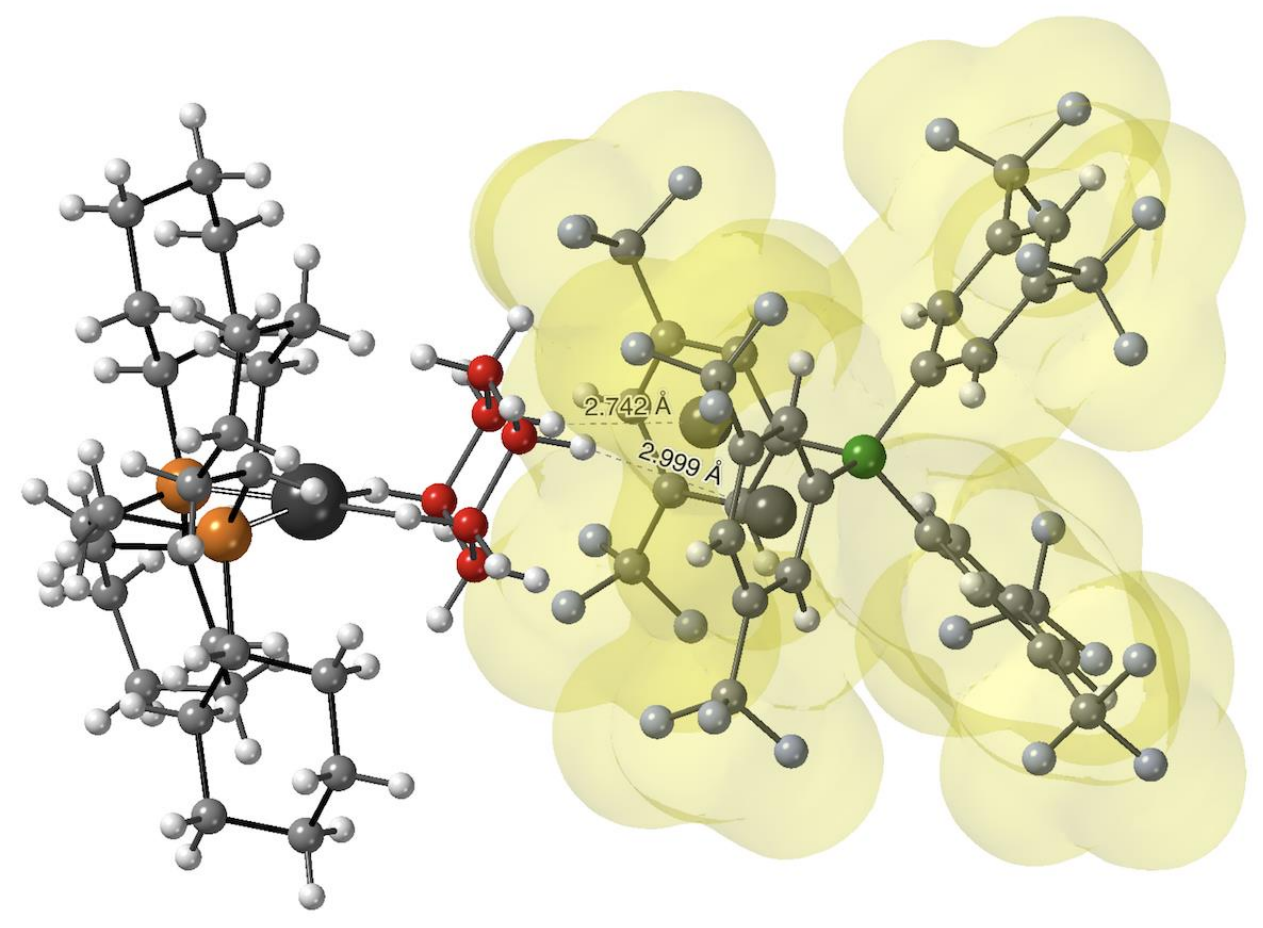

Figure S33: Molecular structure of $\left[1-\mathrm{C}_{6} \mathrm{H}_{12}\right]\left[\mathrm{BAr}_{4}\right]$ showing $\mathrm{C}-\mathrm{H} \cdots \mathrm{F}-\mathrm{C}$ contacts $(<$ 3.0Å) between the cyclohexane ligand and $\left[\mathrm{BAr}_{4}\right]^{-}$anion.

\section{S.2.4.5. Liberation of the bound cyclohexane from $\left[1-\mathrm{C}_{6} \mathrm{H}_{12}\right]\left[B A \mathrm{Br}_{4}\right]$.}

Deep red crystals of $\left[1-\mathbf{C}_{6} \mathbf{H}_{8}\right]\left[\mathbf{B A r}{ }_{4}\right]$ were treated with $\mathrm{H}_{2}$ (2 bar, $298 \mathrm{~K}, 15$ mins) inside a J Young flask. The colour of the crystals immediately darkens to a burgundy color, yielding $\left[1-\mathrm{C}_{6} \mathbf{H}_{12}\right]\left[B \mathrm{Br}_{4}{ }_{4}\right]$. The solid was then cooled to $77 \mathrm{~K}$ under liquid nitrogen and the $\mathrm{J}$ Young flask placed under vacuum to remove any $\mathrm{H}_{2}$. $\mathrm{CO}(1 \mathrm{bar}$, 298K) was added and solid left for 1 hour; to which a vibrant yellow solid material had formed. The solid was then dissolved in $d_{3}-M e C N$, to which the volatile component was isolated by trap-to-trap distillation and analyzed by ${ }^{1} \mathrm{H}$ NMR spectroscopy.

${ }^{1} \mathrm{H}$ NMR $\left(\mathrm{d}_{3}-\mathrm{MeCN}, 400 \mathrm{MHz}\right): \delta 1.44\left(\mathrm{~s}, 12 \mathrm{H}\right.$, alkane- $\left.\mathrm{CH}_{2^{-}}\right)$

The resultant solid was confirmed to be $\left[\mathrm{Rh}(\mathrm{dcpe})(\mathrm{CO})_{2}\right]\left[\mathrm{BAr} \mathrm{F}^{\mathrm{F}}\right]$ by solution NMR ${ }^{31} \mathrm{P}\left\{{ }^{1} \mathrm{H}\right\}$ NMR spectroscopy $\left(\delta 85.22, \mathrm{~d}, \mathrm{~J}_{\mathrm{RhP}}=116 \mathrm{~Hz}\right) .{ }^{\mathrm{S} 7}$ 


\section{S.2.4.6. Solid state decomposition products of [1-C $\left.{ }_{6} \mathrm{H}_{12}\right]\left[B A \mathrm{Br}_{4}\right]$ under $\mathrm{H}_{2}$}

A powdered microcrystalline sample of $\left[1-\mathbf{C}_{6} \mathbf{H}_{8}\right]\left[\mathrm{BAr}_{4}{ }_{4}\right](35 \mathrm{mg})$ was packed in a 3.2 mm SSNMR rotor, inside an argon filled glove box. The rotor was then placed in a custom built glass $\mathrm{J}$ Young flask ${ }^{\mathrm{S7}}$ and the sample was then exposed to $\mathrm{H}_{2}$ (1 bar, $298 \mathrm{~K}$ ). After 80 minutes, the rotor cap was fitted under a flush of $\mathrm{H}_{2}$. The sample was immediately transferred to the bore of a pre-cooled (158 K) SSNMR spectrometer $(\sim 10$ mins, total time $=90$ mins $)$ and analyzed ${ }^{31} \mathrm{P}\left\{{ }^{1} \mathrm{H}\right\}$ and ${ }^{13} \mathrm{C}\left\{{ }^{1} \mathrm{H}\right\}$ solid state NMR spectroscopy.

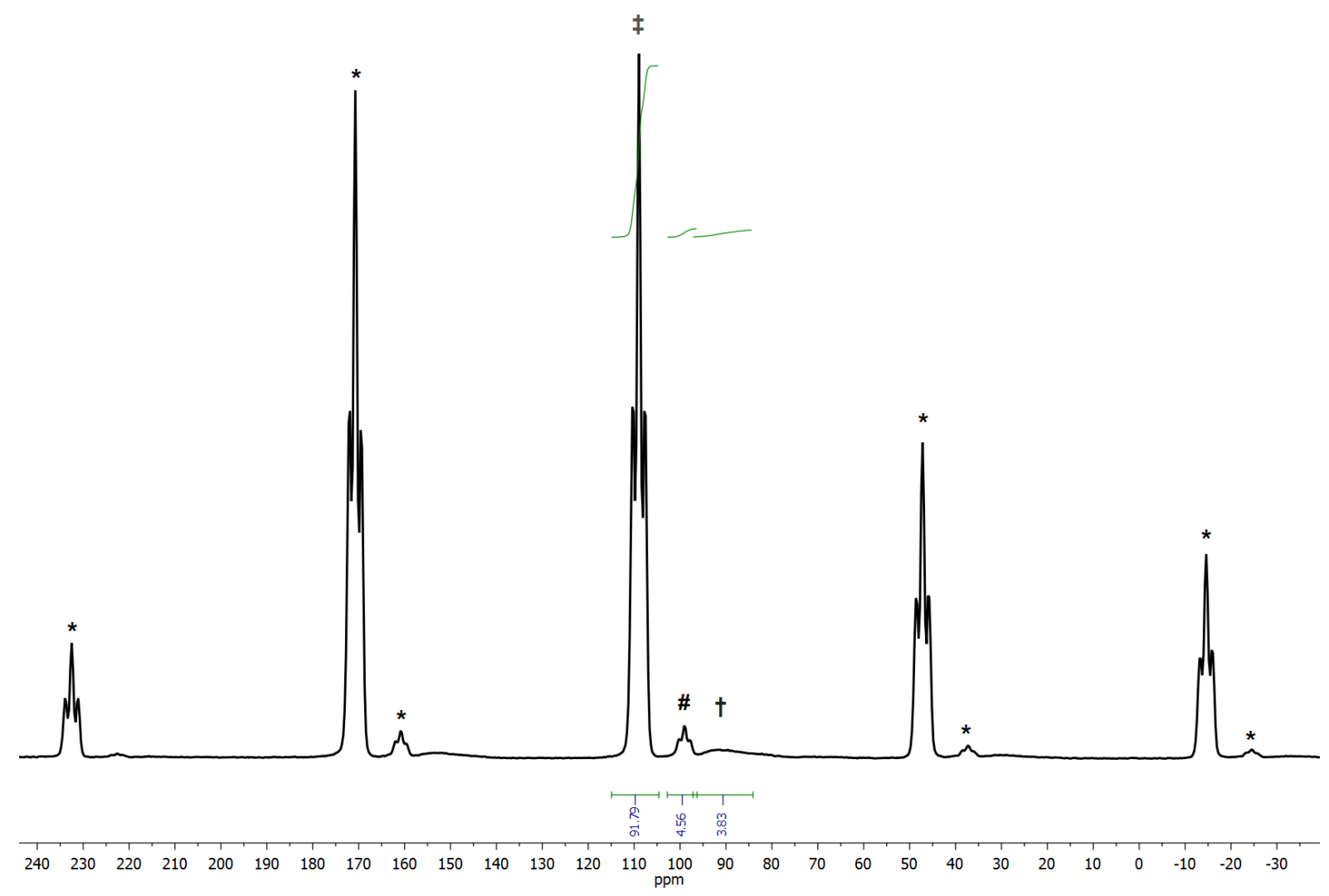

Figure S34: The ${ }^{31} \mathrm{P}\left\{{ }^{1} \mathrm{H}\right\}$ SSNMR (162 MHz, $295 \mathrm{~K}, 10 \mathrm{kHz}$ spin rate) spectrum of the solid state decomposition products of $\left[1-\mathrm{C}_{6} \mathbf{H}_{12}\right]\left[\mathbf{B A r}{ }_{4}{ }_{4}\right]$ under $\mathrm{H}_{2}$ after 90 minutes. The resonances $\ddagger$ marked are assigned to $\left[1-\mathrm{C}_{6} \mathrm{H}_{12}\right]\left[B \mathrm{Br}_{4}\right.$ ] (approx. 90\%) and the resonances marked $\dagger$ are assigned to [1-BAr $\left.{ }_{4}\right]^{\mathrm{S} 2}$ (approx. 5\%). The resonance marked \# at $\delta 100$ is unidentified complex under $\mathrm{H}_{2}$ (approx. 5\%), also seen in the decomposition of $\left[1-\mathbf{C}_{4} \mathbf{H}_{10}\right]\left[\mathbf{B A r}{ }_{4}\right]$ also under hydrogen atmosphere (section S.2.2.6.). The resonances marked * are due to spinning sidebands. 


\section{S.2.5. $\left[\mathrm{Rh}\left(\mathrm{Cy}_{2} \mathrm{PCH}_{2} \mathrm{CH}_{2} \mathrm{PCy}_{2}\right)\left(\mathrm{C}_{6} \mathrm{H}_{6}\right)\right]\left[B A \mathrm{~F}_{4}\right],\left[1-\mathrm{C}_{6} \mathrm{H}_{6}\right]\left[\mathrm{BAr}{ }_{4}\right]$}

\section{S.2.5.1. Synthesis of $\left[1-\mathrm{C}_{6} \mathrm{H}_{6}\right]\left[B \mathrm{Br}_{4}{ }_{4}\right]$}

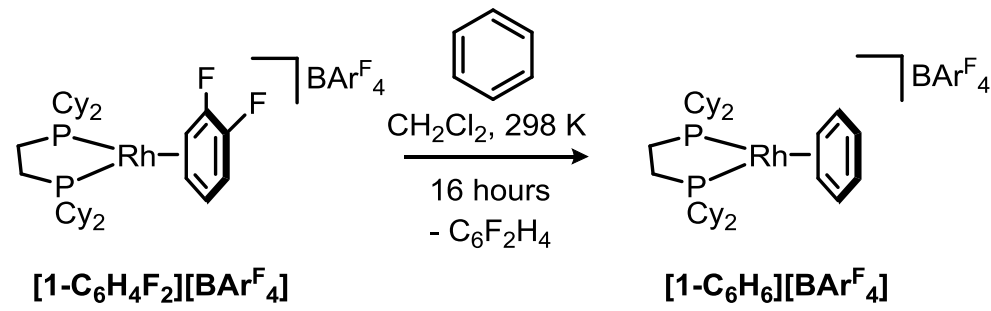

A solution of [1- $\left.\mathrm{C}_{6} \mathrm{H}_{4} \mathrm{~F}_{2}\right]\left[\mathrm{BAr}_{4}{ }_{4}\right](70 \mathrm{mg}, 46.6 \mu \mathrm{mol})$ in $\mathrm{CH}_{2} \mathrm{Cl}_{2}(5 \mathrm{~mL})$ was treated with $\mathrm{C}_{6} \mathrm{H}_{6}(100 \mu \mathrm{L})$ at ambient temperature. The resultant yellow solution was stirred at ambient temperature for 16 hours, and then filtered. Addition of pentane afforded a yellow powder, which was washed with further pentane and then dried under vacuum. Yield: $59 \mathrm{mg}(86 \%)$.

\section{S.2.5.2. Characterization data for $\left[1-\mathrm{C}_{6} \mathrm{H}_{6}\right]\left[B \mathrm{Br}_{4}{ }_{4}\right]$}

${ }^{1} \mathrm{H}$ NMR $\left(\mathrm{CD}_{2} \mathrm{Cl}_{2}, 298 \mathrm{~K}, 400 \mathrm{MHz}\right): \delta 7.72$ (s, 8H, ortho-ArH), 7.57 (s, $4 \mathrm{H}$, paraArH), $6.52\left(\mathrm{~s}, 6 \mathrm{H}, \mathrm{C}_{6} \mathrm{H}_{6}\right), 1.91-1.59$ (br m, 28H, overlapping aliphatic $\left.\mathrm{CH}\right), 1.37-1.14$ (br m, 16H, aliphatic $\mathrm{CH}$ ), 1.04-0.94 (br m, 4H, overlapping aliphatic $\mathrm{CH}$ ).

${ }^{1} \mathrm{H}$ NMR $\left(\mathrm{CD}_{2} \mathrm{Cl}_{2}, 183 \mathrm{~K}, 400 \mathrm{MHz}\right): \delta 7.72$ (s, 8H, ortho-ArH), 7.54 (s, 4H, paraArH), $6.44\left(\mathrm{~s}, 6 \mathrm{H}, \mathrm{C}_{6} \mathrm{H}_{6}\right), 1.78-1.44$ (br m, 28H, overlapping aliphatic $\mathrm{CH}$ ), 1.26-0.96 (br m, 16H, aliphatic $\mathrm{CH}$ ), 0.92-0.79 (br m, 4H, overlapping aliphatic $\mathrm{CH}$ ).

${ }^{31} \mathrm{P}\left\{{ }^{1} \mathrm{H}\right\} \operatorname{NMR}\left(\mathrm{CD}_{2} \mathrm{Cl}_{2}, 298 \mathrm{~K}, 162 \mathrm{MHz}\right): \delta 99.7$ (d, JRhP $\left.201 \mathrm{~Hz}\right)$.

${ }^{31} \mathrm{P}\left\{{ }^{1} \mathrm{H}\right\} \operatorname{NMR}\left(\mathrm{CD}_{2} \mathrm{Cl}_{2}, 183 \mathrm{~K}, 162 \mathrm{MHz}\right): \delta 99.4$ (d, JRhP $\left.201 \mathrm{~Hz}\right)$.

${ }^{19} \mathrm{~F}\left\{{ }^{1} \mathrm{H}\right\}$ NMR $\left(\mathrm{CD}_{2} \mathrm{Cl}_{2}, 298 \mathrm{~K}, 377 \mathrm{MHz}\right): \delta-62.9$ (s).

${ }^{13} \mathrm{C}\left\{{ }^{1} \mathrm{H}\right\}$ NMR ( $\mathrm{CD}_{2} \mathrm{Cl}_{2}, 298 \mathrm{~K}, 126 \mathrm{MHz}$ ): $\delta 162.2$ (q, J J $50 \mathrm{~Hz}$, ipso-ArC), 135.2 (s, ortho-ArC), 129.3 (q, J JF $32 \mathrm{~Hz}$, meta-ArC), 125.0 (q, J JF $272 \mathrm{~Hz}, \mathrm{CF}_{3}$ ), 117.9 (m, para-ArC), 99.6 (d, J JRh $1.9 \mathrm{~Hz}, \mathrm{C}_{6} \mathrm{H}_{6}$ ), 38.6 (m, cyclohexyl-CH), 29.4 (m, cyclohexyl$\mathrm{CH}_{2}$ ), 27.1 (m, cyclohexyl- $\mathrm{CH}_{2}$ ), 26.4 (s, cyclohexyl- $\left.\mathrm{CH}_{2}\right), 22.9$ (m, cyclohexyl- $\mathrm{CH}_{2}$ ).

ESI-MS found (calc. for $\left.\left[\mathrm{Rh}\left(\mathrm{Cy}_{2} \mathrm{PCH}_{2} \mathrm{CH}_{2} \mathrm{PCy}_{2}\right)\left(\mathrm{C}_{6} \mathrm{H}_{6}\right)\right]^{+}\right): \mathrm{m} / \mathrm{z} 603.29$ (603.28).

Elemental analysis found (calc. for $\mathrm{C}_{64} \mathrm{H}_{66} \mathrm{BF}_{24} \mathrm{P}_{2} \mathrm{Rh}$ ): $\mathrm{C} 52.29$ (52.40), H 4.35 (4.54). 


\section{S.2.5.3. Spectra of $\left[1-\mathrm{C}_{6} \mathrm{H}_{6}\right]\left[\mathrm{BAr}_{4}\right]$}

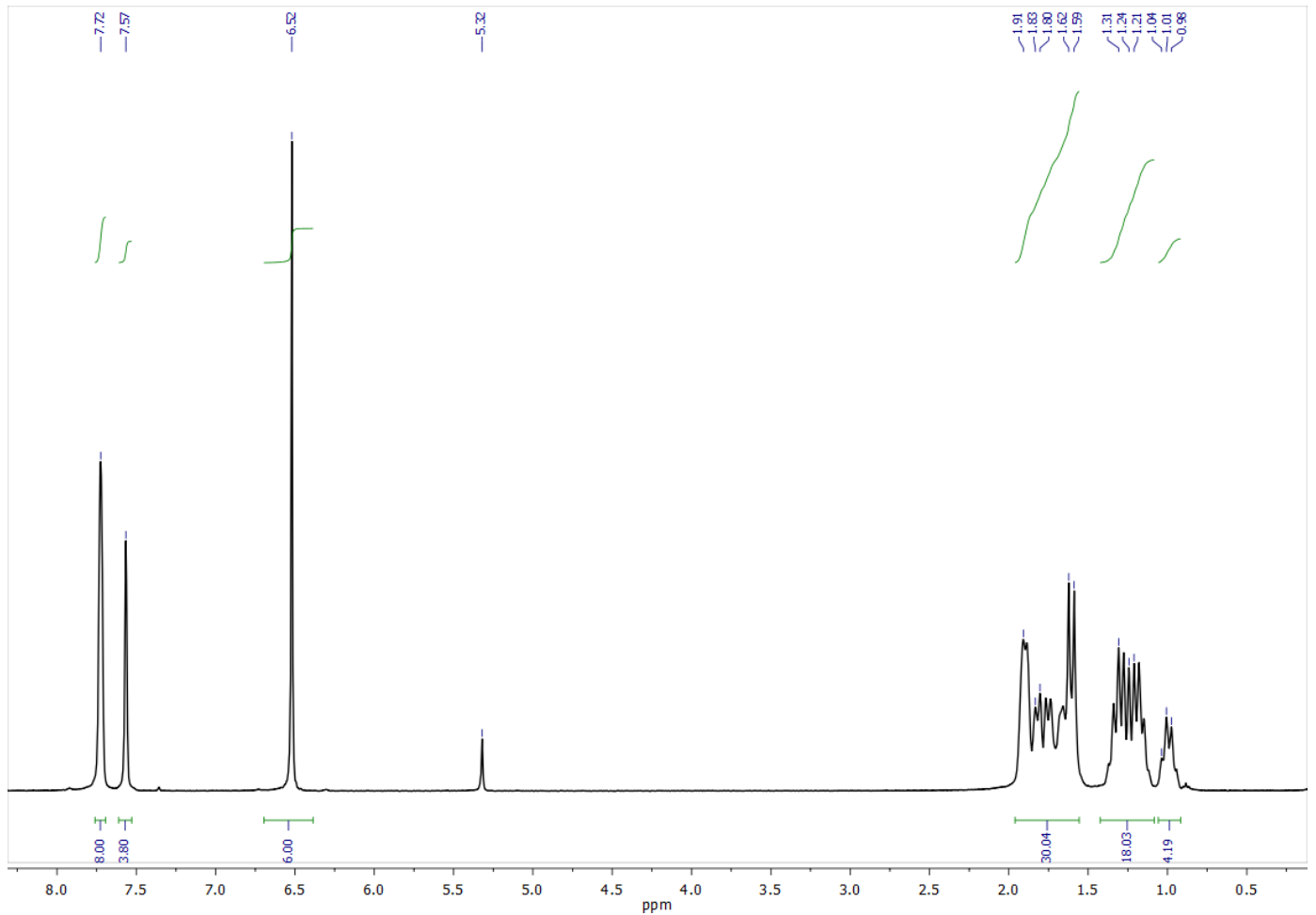

Figure S35: The solution ${ }^{1} \mathrm{H}$ NMR $\left(\mathrm{CD}_{2} \mathrm{Cl}_{2}, 298 \mathrm{~K}, 400 \mathrm{MHz}\right)$ spectrum of [1$\left.\mathrm{C}_{6} \mathrm{H}_{6}\right]\left[\mathrm{BAr}_{4}{ }_{4}\right]$.
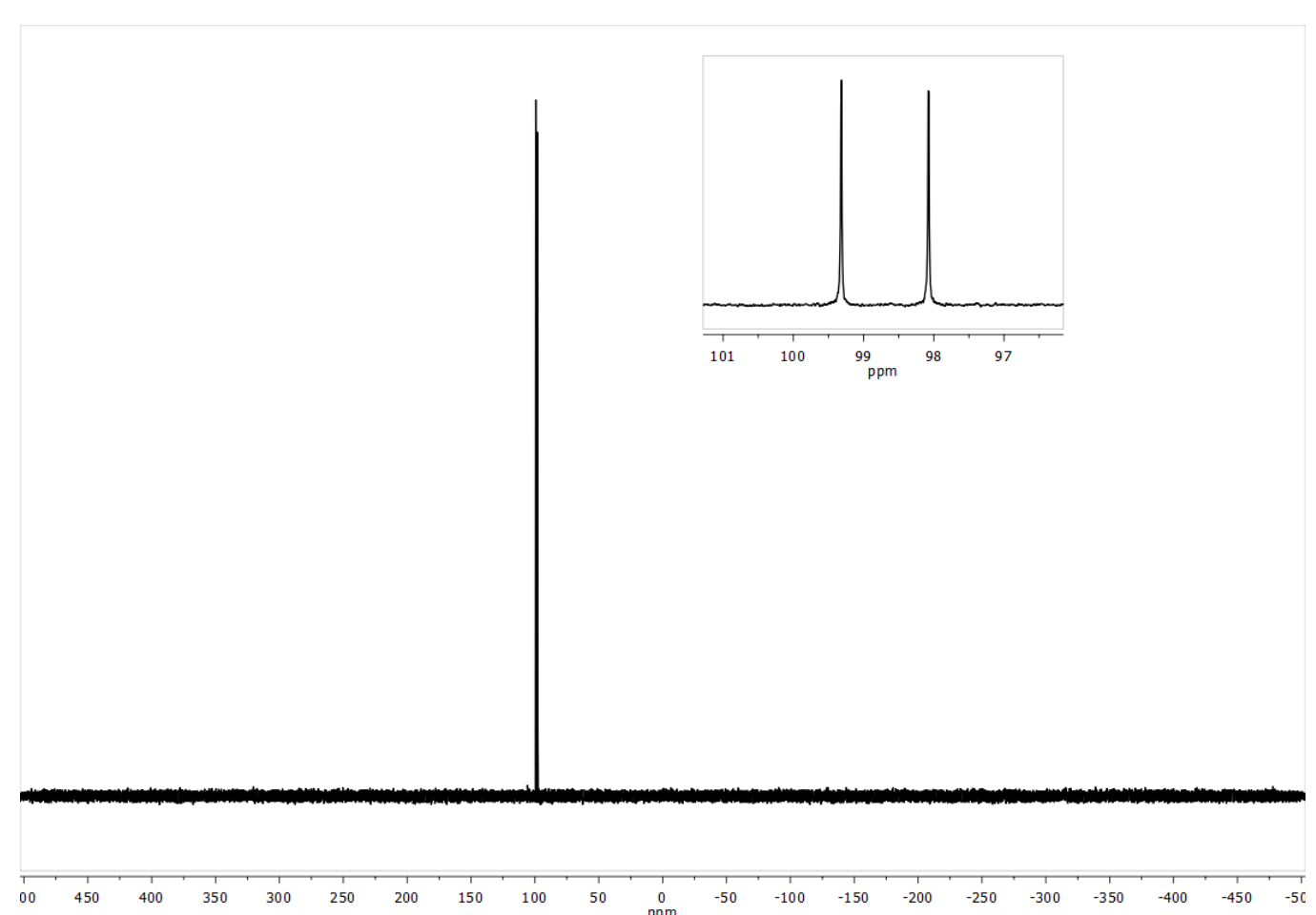

Figure S36: The solution ${ }^{31} \mathrm{P}\left\{{ }^{1} \mathrm{H}\right\} \mathrm{NMR}\left(\mathrm{CD}_{2} \mathrm{Cl}_{2}, 298 \mathrm{~K}, 162 \mathrm{MHz}\right)$ spectrum of [1$\left.\mathrm{C}_{6} \mathrm{H}_{6}\right]\left[\mathrm{BAr}{ }_{4}\right]$. 

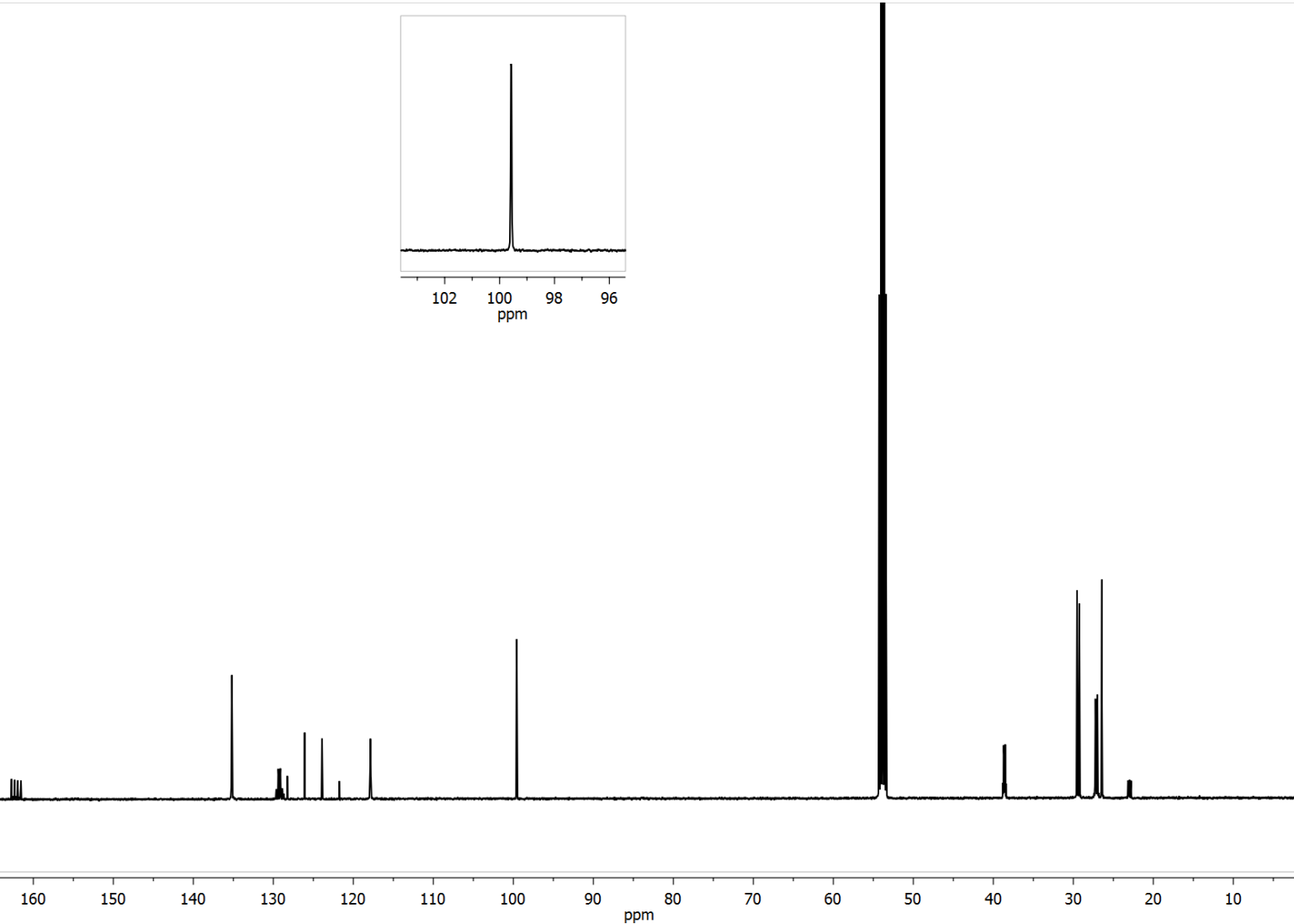

Figure S37: The solution ${ }^{13} \mathrm{C}\left\{{ }^{1} \mathrm{H}\right\} \mathrm{NMR}\left(\mathrm{CD}_{2} \mathrm{Cl}_{2}, 298 \mathrm{~K}, 126 \mathrm{MHz}\right)$ spectrum of [1$\left.\mathrm{C}_{6} \mathrm{H}_{6}\right]$ [BAr ${ }_{4}{ }^{\mathrm{F}}$. The inset shows an enlargement of the benzene carbon signals at $\delta$ 99.6. 


\section{S.2.6. $\left[\mathrm{Rh}\left(\mathrm{Cy}_{2} \mathrm{PCH}_{2} \mathrm{CH}_{2} \mathrm{PCy}_{2}\right)\left(\mathrm{C}_{6} \mathrm{D}_{6}\right)\right]\left[\mathrm{BAr}{ }_{4}\right],\left[1-\mathrm{C}_{6} \mathrm{D}_{6}\right]\left[\mathrm{BAr}{ }_{4}\right]$}

\section{S.2.6.1. Synthesis of $\left[1-\mathrm{C}_{6} \mathrm{D}_{6}\right]\left[\mathrm{BAr}{ }_{4}\right]$}

A solution of [1- $\mathrm{C}_{6} \mathrm{H}_{4} \mathrm{~F}_{2}$ ] [BAr ${ }_{4}$ ] (35 mg, $\left.23.3 \mu \mathrm{mol}\right)$ in $\mathrm{CH}_{2} \mathrm{Cl}_{2}(3 \mathrm{~mL})$ was treated with $\mathrm{C}_{6} \mathrm{D}_{6}(50 \mu \mathrm{L})$ at ambient temperature. The resultant yellow solution was stirred at ambient temperature for 16 hours and then filtered. Addition of pentane afforded a yellow powder, which was washed with further pentane and then dried under vacuum. Yield: $17 \mathrm{mg}$ (50\%).

\section{S.2.6.2. Characterization data for $\left[1-\mathrm{C}_{6} \mathrm{D}_{6}\right]\left[\mathrm{BAr}{ }_{4}\right]$}

${ }^{1} \mathrm{H}$ NMR $\left(\mathrm{CD}_{2} \mathrm{Cl}_{2}, 298 \mathrm{~K}, 400 \mathrm{MHz}\right): \delta 7.72$ (s, 8H, ortho-ArH), 7.56 (s, 4H, para$\mathrm{ArH}), 1.91-1.59$ (br m, 28H, overlapping aliphatic $\mathrm{CH}$ ), 1.37-1.14 (br m, $16 \mathrm{H}$, aliphatic $\mathrm{CH}$ ), 1.04-0.94 (br m, 4H, overlapping aliphatic $\mathrm{CH}$ ).

${ }^{1} \mathrm{H}$ NMR $\left(\mathrm{CD}_{2} \mathrm{Cl}_{2}, 183 \mathrm{~K}, 400 \mathrm{MHz}\right): \delta 7.72$ (s, 8H, ortho-ArH), 7.54 (s, 4H, para$\mathrm{ArH}), 1.78-1.44$ (br m, $28 \mathrm{H}$, overlapping aliphatic $\mathrm{CH}), 1.26-0.96(\mathrm{br} \mathrm{m}, 16 \mathrm{H}$, aliphatic $\mathrm{CH}$ ), 0.92-0.79 (br m, $4 \mathrm{H}$, overlapping aliphatic $\mathrm{CH}$ ).

${ }^{2} \mathrm{H}$ NMR $\left(\mathrm{CD}_{2} \mathrm{Cl}_{2}, 298 \mathrm{~K}, 61 \mathrm{MHz}\right): \delta 6.56\left(\mathrm{~s}, \mathrm{C}_{6} \mathrm{D}_{6}\right)$.

${ }^{31} \mathrm{P}\left\{{ }^{1} \mathrm{H}\right\} \operatorname{NMR}\left(\mathrm{CD}_{2} \mathrm{Cl}_{2}, 298 \mathrm{~K}, 162 \mathrm{MHz}\right): \delta 98.7\left(\mathrm{~d}, \mathrm{~J}_{\mathrm{RhP}} 201 \mathrm{~Hz}\right)$.

${ }^{31} \mathrm{P}\left\{{ }^{1} \mathrm{H}\right\} \operatorname{NMR}\left(\mathrm{CD}_{2} \mathrm{Cl}_{2}, 183 \mathrm{~K}, 162 \mathrm{MHz}\right): \delta 99.5\left(\mathrm{~d}, \mathrm{~J}_{\mathrm{RhP}} 201 \mathrm{~Hz}\right)$.

${ }^{19} \mathrm{~F}\left\{{ }^{1} \mathrm{H}\right\} \mathrm{NMR}\left(\mathrm{CD}_{2} \mathrm{Cl}_{2}, 298 \mathrm{~K}, 377 \mathrm{MHz}\right): \delta-62.9$ (s).

${ }^{13} \mathrm{C}\left\{{ }^{1} \mathrm{H}\right\} \operatorname{NMR}\left(\mathrm{CD}_{2} \mathrm{Cl}_{2}, 298 \mathrm{~K}, 126 \mathrm{MHz}\right.$ ): $\delta 162.2$ (q, J $\mathrm{J}_{\mathrm{CB}} 50 \mathrm{~Hz}$, ipso-ArC), 135.2 (s, ortho-ArC), 129.3 (q, J JF $32 \mathrm{~Hz}$, meta-ArC), 125.0 (q, J JF $272 \mathrm{~Hz}, \mathrm{CF}_{3}$ ), 117.9 (m, para-ArC), 99.2 (t, $\mathrm{J}_{\mathrm{CD}} 26.1 \mathrm{~Hz}, \mathrm{C}_{6} \mathrm{H}_{6}$ ), 38.6 (m, cyclohexyl-CH), 29.5 (s, cyclohexyl$\mathrm{CH}_{2}$ ), 29.2 (s, cyclohexyl- $\mathrm{CH}_{2}$ ), $27.2\left(\mathrm{~m}\right.$, cyclohexyl- $\left.\mathrm{CH}_{2}\right), 27.0$ (m, cyclohexyl- $\mathrm{CH}_{2}$ ), 26.4 (s, cyclohexyl- $\mathrm{CH}_{2}$ ), 23.1 (m, cyclohexyl- $\mathrm{CH}_{2}$ ), 23.0 (m, cyclohexyl- $\left.\mathrm{CH}_{2}\right), 23.0$ (br s, cyclohexyl- $\mathrm{CH}_{2}$ ), 22.8 (m, cyclohexyl- $\mathrm{CH}_{2}$ ).

ESI-MS found (calc. for $\left.\left[\mathrm{Rh}\left(\mathrm{Cy}_{2} \mathrm{PCH}_{2} \mathrm{CH}_{2} \mathrm{PCy}_{2}\right)\left(\mathrm{C}_{6} \mathrm{D}_{6}\right)\right]^{+}\right): \mathrm{m} / \mathrm{z} 609.32$ (609.31). 


\section{S.3. H/D Exchange Experiments}

\section{S.3.1. Solid-state $\mathrm{H} / \mathrm{D}$ exchange on $\left[1-\mathrm{C}_{4} \mathrm{H}_{8}\right]\left[\mathrm{BAr}{ }_{4}\right]$}

\section{S.3.1.1. General Experimental of $H / D$ Exchange on $\left[1-\mathrm{C}_{4} \mathrm{H}_{8}\right]\left[B \mathrm{Br}_{4}{ }_{4}\right]$}

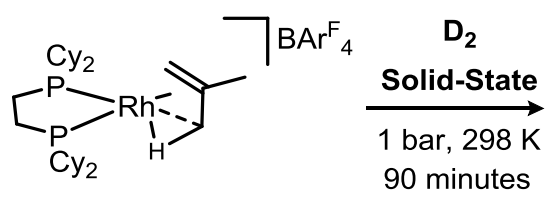

$\left[1-\mathrm{C}_{4} \mathrm{H}_{8}\right]\left[\mathrm{BAr}_{4}\right]$

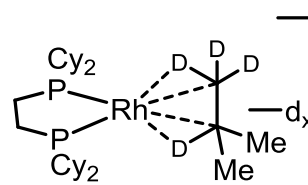

$\left[1-\mathrm{C}_{4} \mathrm{D}_{\mathrm{X}}\right.$-alkane][BArF$\left.{ }_{4}\right]$

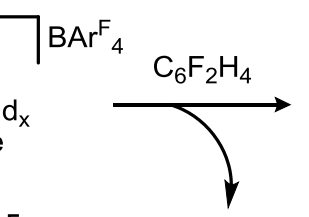

$\gamma-d_{x}$<smiles>CC(C)C</smiles>

Isobutane-d $d_{x}(x=10-7)$

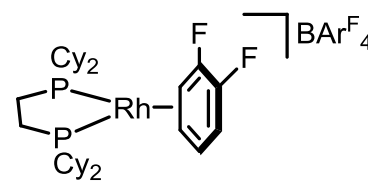

$\left[1-\mathrm{C}_{6} \mathrm{H}_{4} \mathrm{~F}_{2}\right]\left[\mathrm{BAr}{ }_{4}\right]$

A J Young NMR tube ( $2 \mathrm{~mL}$ ) was charged with 25 mgs of an orange crystalline sample of $\left[1-\mathbf{C}_{4} \mathrm{H}_{8}\right]\left[\mathrm{BAr}_{4}\right]$. The tube was evacuated $\left(<3 \times 10^{-2} \mathrm{mbar}\right)$ and $\mathrm{D}_{2}(1 \mathrm{bar}$, 298 K) was added. The color of the crystals immediately turned a dark red, yielding the deuterated analogue of $\left[1-\mathrm{C}_{4} \mathrm{H}_{10}\right]\left[\mathrm{BAr}_{4}{ }_{4}\right] ;\left[1-\mathrm{C}_{4} \mathrm{D}_{\mathrm{x}}\right.$-alkane][BAr${ }_{4}{ }_{4}$.

The reaction was left for 90 minutes; after which the crystal color changed to a dark orange. After this time, it was found isobutane- $d_{x}(x=10-7)$ had been expelled from the crystal lattice, shown by gas phase ${ }^{1} \mathrm{H}$ and ${ }^{2} \mathrm{H}$ NMR spectroscopy of the NMR tube headspace. ${ }^{\mathrm{S} 6}$ The volatiles were then distilled into a clean NMR tube with $\mathrm{CD}_{2} \mathrm{Cl}_{2}$ and analyzed by ${ }^{1} \mathrm{H},{ }^{2} \mathrm{H},{ }^{13} \mathrm{C}\left\{{ }^{1} \mathrm{H}\right\}$ NMR spectroscopy and GC EI-MS.

The remaining solid material was dissolved in $\mathrm{C}_{6} \mathrm{~F}_{2} \mathrm{H}_{4}$ to quantitatively yield [1$\left.\mathbf{C}_{6} \mathbf{F}_{2} \mathrm{H}_{4}\right]\left[\mathrm{BAr}_{4}\right]$ complex. No isobutane could be identified in the solution ${ }^{1} \mathrm{H}$ or ${ }^{2} \mathrm{H}$ NMR spectrum, suggesting total expulsion of isobutane from the lattice by $D_{2}$ is complete after 90 minutes.

\section{S.3.1.2. Characterization data for isobutane- $d_{x}$}

${ }^{1} \mathrm{H}$ NMR $\left(\mathrm{CD}_{2} \mathrm{Cl}_{2}, 400 \mathrm{MHz}, 183 \mathrm{~K}\right): \delta 0.86$ (br m, $\mathrm{CH}_{3}$, residual protio-isobutane)

${ }^{2} \mathrm{H}$ NMR $\left(\mathrm{CD}_{2} \mathrm{Cl}_{2}, 61 \mathrm{MHz}, 183 \mathrm{~K}\right): \delta 1.66$ (br s, CD), 0.85 (br s, $\left.\mathrm{CD}_{3}\right)$.

${ }^{13} \mathrm{C}\left\{{ }^{1} \mathrm{H}\right\} \mathrm{NMR}\left(\mathrm{CD}_{2} \mathrm{Cl}_{2}, 126 \mathrm{MHz}, 183 \mathrm{~K}\right): \delta 23.6$ (septet, $\left.\mathrm{CD}_{3}, \mathrm{~J}_{\mathrm{CD}}=18.8\right), 22.5$ (triplet, $C D, J_{C D}=20.1$ ), for $C_{4} D_{10}$, but also formed is $C_{4} H D_{9}, C_{4} H_{2} D_{8}$ and $C_{4} H_{3} D_{7}$.

GC El-MS found (calc. for $\mathrm{C}_{4} \mathrm{D}_{9}{ }^{+}$): $\mathrm{m} / \mathrm{z} 66.127$ (66.127). 
S.3.1.3. NMR Spectra of isobutane- $d_{x}(x=10-7)$
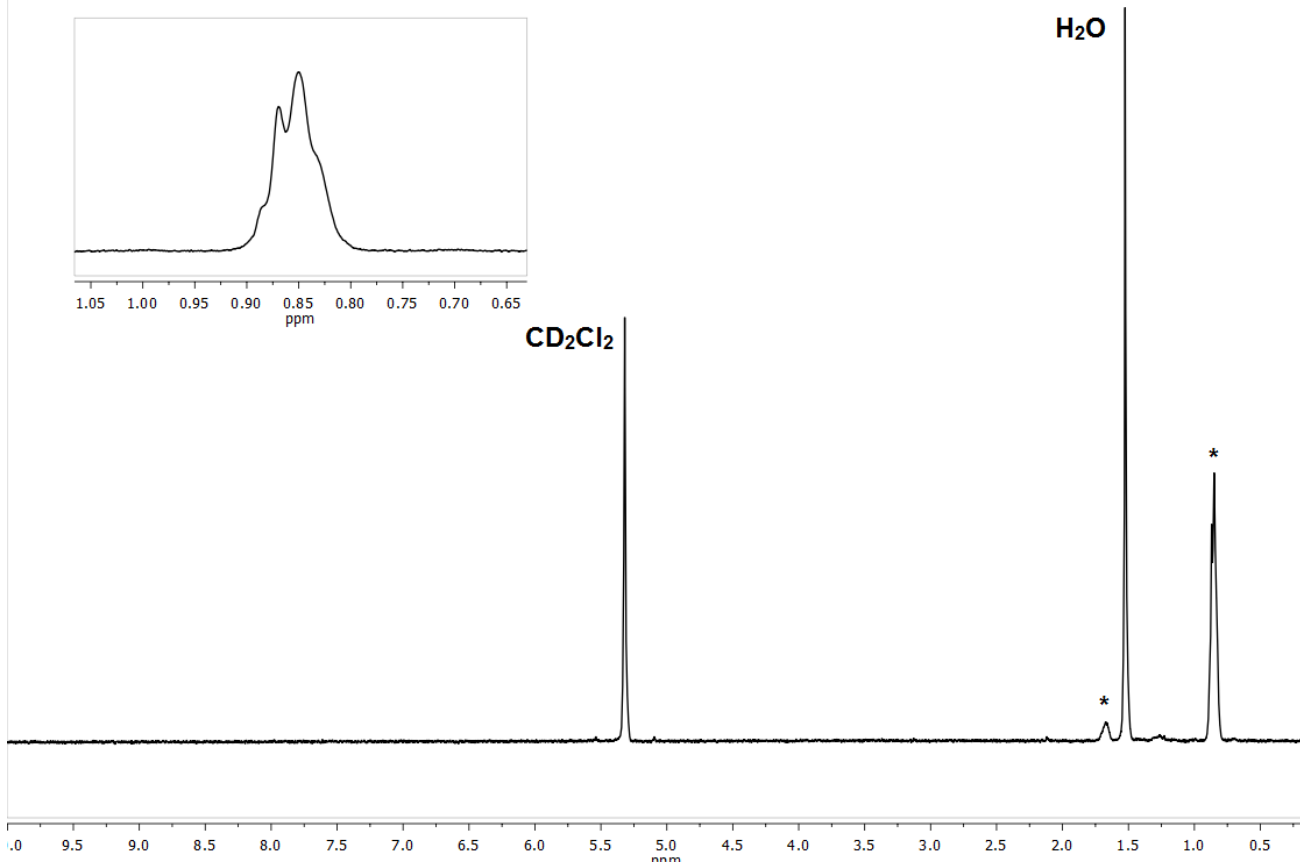

Figure S38: The solution ${ }^{1} \mathrm{H}$ NMR $\left(\mathrm{CD}_{2} \mathrm{Cl}_{2}, 298 \mathrm{~K}, 400 \mathrm{MHz}\right)$ spectrum of isolated volatiles. Residual protio-isobutane signals observed are marked with *.

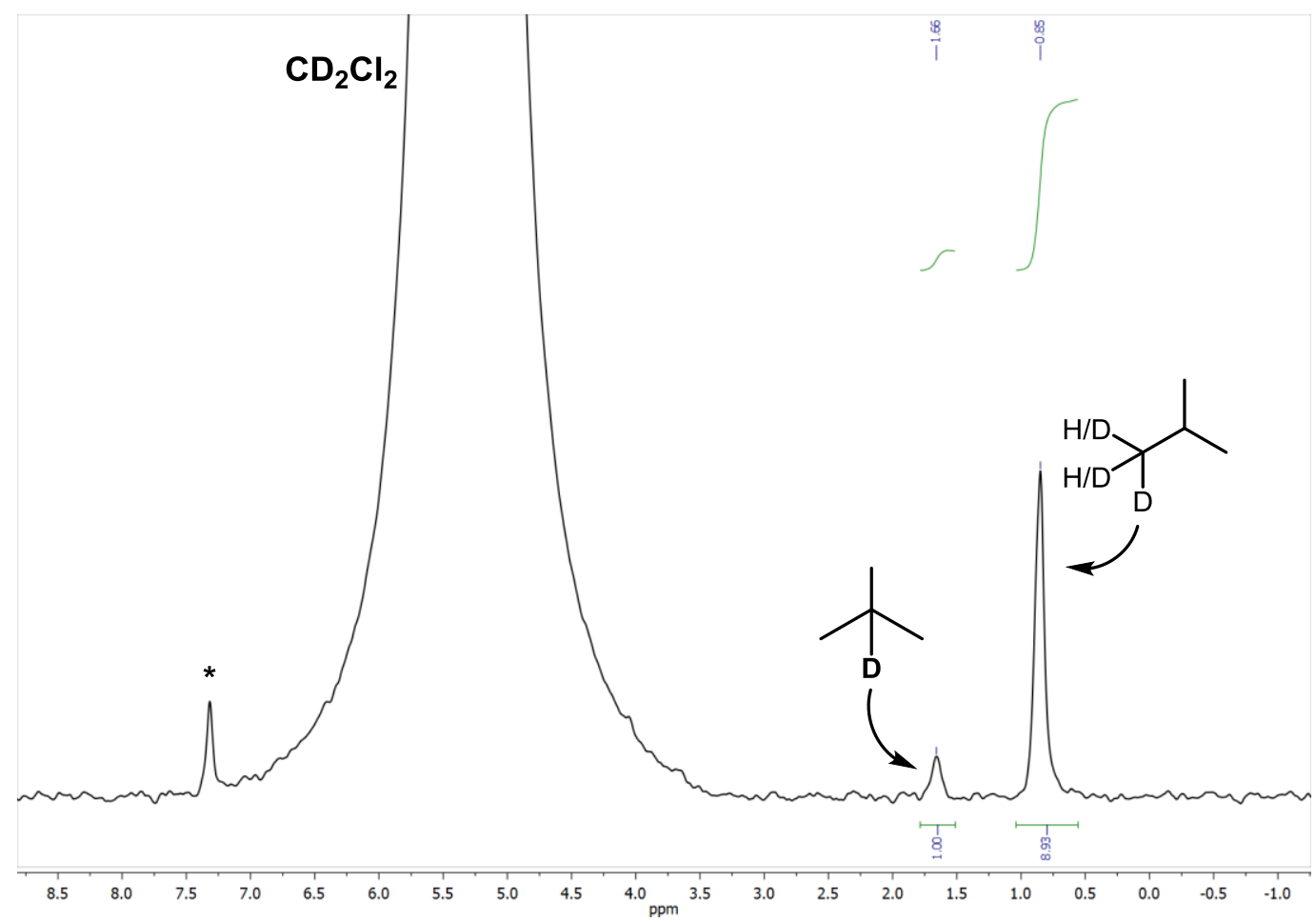

Figure S39: The solution ${ }^{2} \mathrm{H}$ NMR $\left(\mathrm{CD}_{2} \mathrm{Cl}_{2}, 298 \mathrm{~K}, 61 \mathrm{MHz}\right)$ spectrum of isolated volatiles. The signal marked ${ }^{*}$ is from a $\mathrm{CDCl}_{3}$ impurity. 


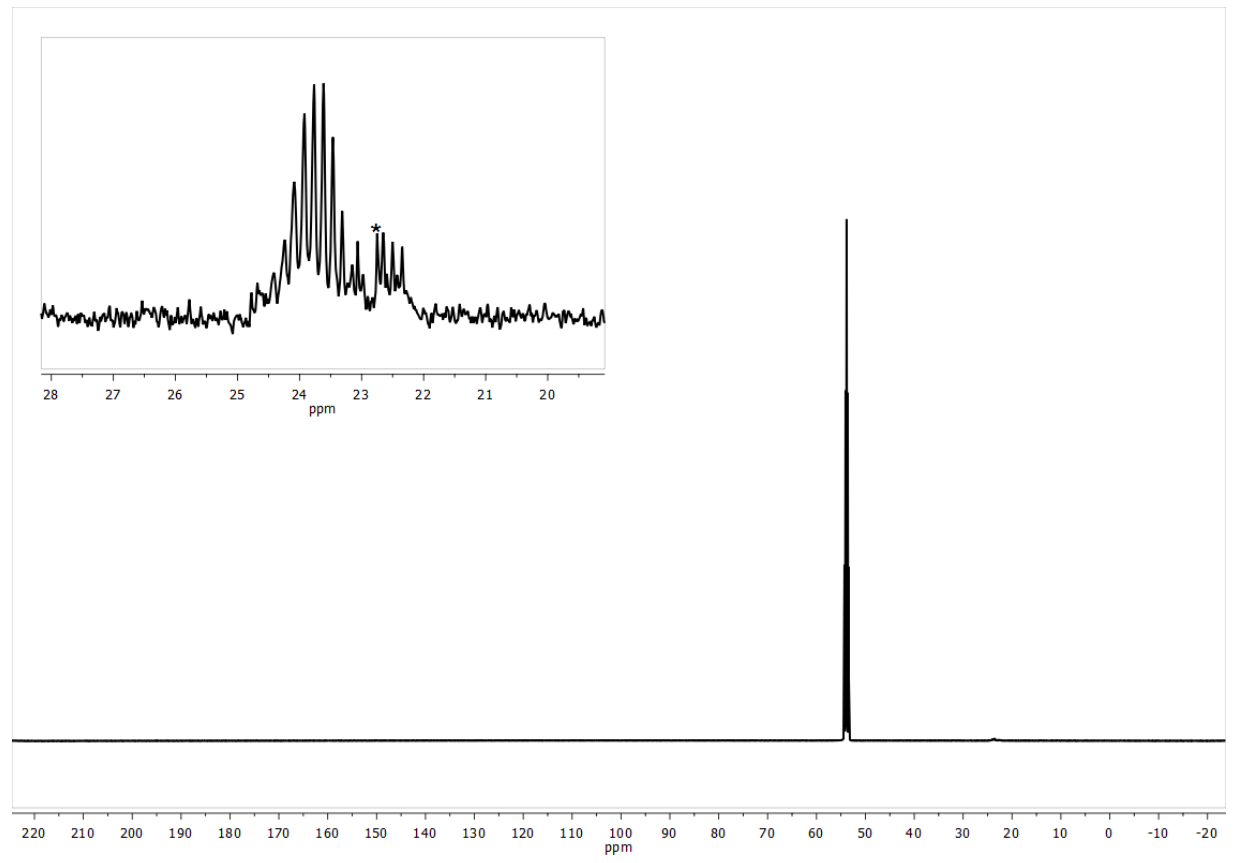

Figure S40: The solution ${ }^{13} \mathrm{C}\left\{{ }^{1} \mathrm{H}\right\} \mathrm{NMR}\left(\mathrm{CD}_{2} \mathrm{Cl}_{2}, 298 \mathrm{~K}, 126 \mathrm{MHz}\right)$ spectrum of isolated volatiles. The inset in an enlargement of the resonances between $\delta 27-20$, where the signal marked * is from a pentane impurity. 


\section{S.3.1.3. GC EI-MS Spectra of isobutane- $d_{x}(x=10-7)$ and isobutane- $h_{10}$}

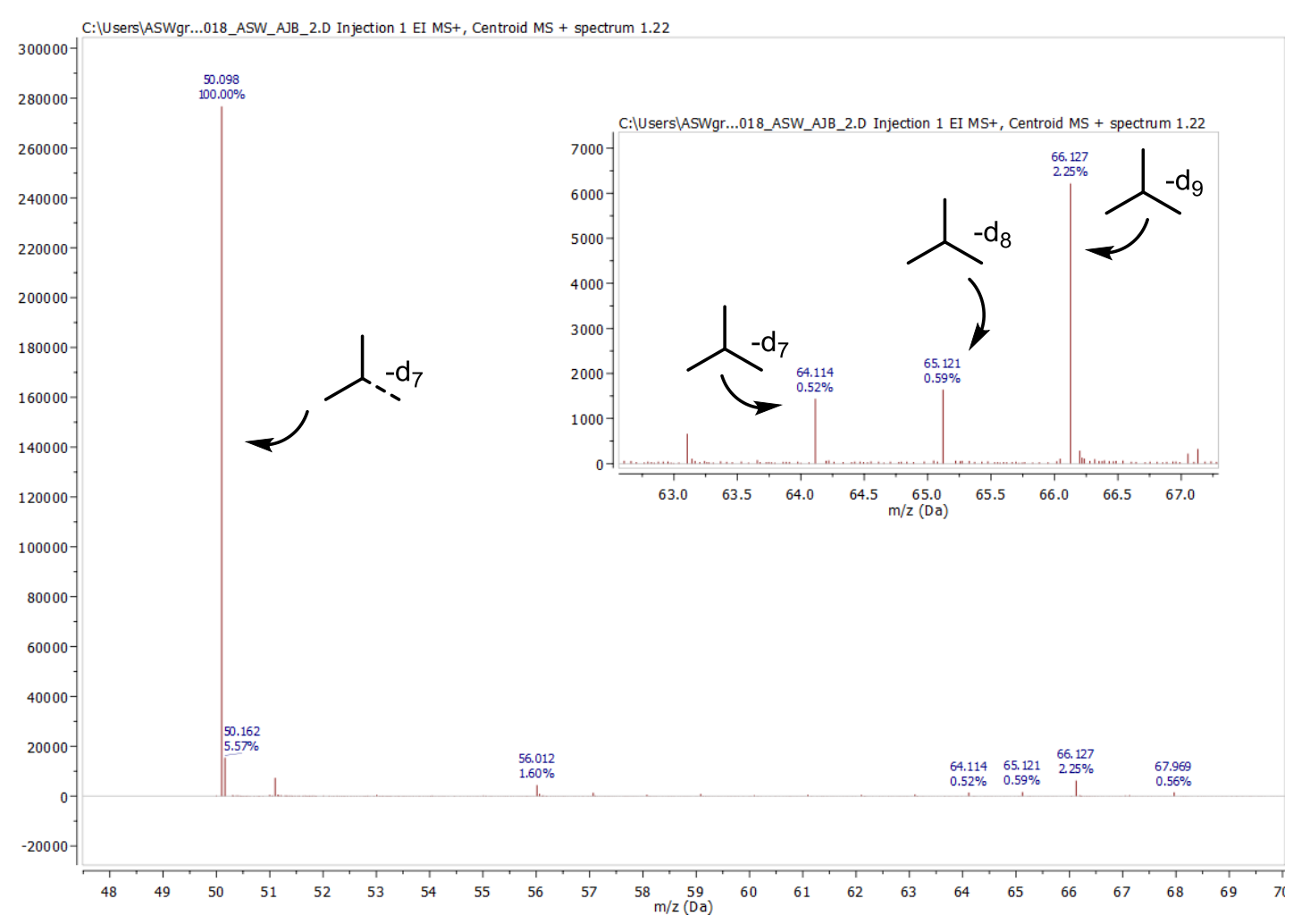

Figure S41: Mass spectrum of the isolated isobutane- $d_{x}$ with enlargement of $\mathrm{m} / \mathrm{z}=$ $62-69$ region. Due to relative ease of fragmentation of isobutane, ${ }^{58}$ the molecular ion peak is that of $\mathrm{C}_{4} \mathrm{D}_{9}{ }^{+}, \mathrm{m} / \mathrm{z}=66.127$ (calc. 66.1269) with greatest intensity fragment of $\mathrm{C}_{3} \mathrm{D}_{7}{ }^{+}, \mathrm{m} / \mathrm{z}=50.098$ (calc. $=50.098$ ). Other main isotopologues are of $\mathrm{C}_{4} \mathrm{HD}_{8}{ }^{+}, \mathrm{m} / \mathrm{z}=65.121$ (calc. 65.120 ), $\mathrm{C}_{4} \mathrm{H}_{2} \mathrm{D}_{7}{ }^{+}, \mathrm{m} / \mathrm{z}=64.114$ (calc. 64.114).

To further show the relative ease of fragmentation; commercially bought isobutane$\mathrm{H}_{10}$ was studied using GC EI-MS, shown in Figure S42. 


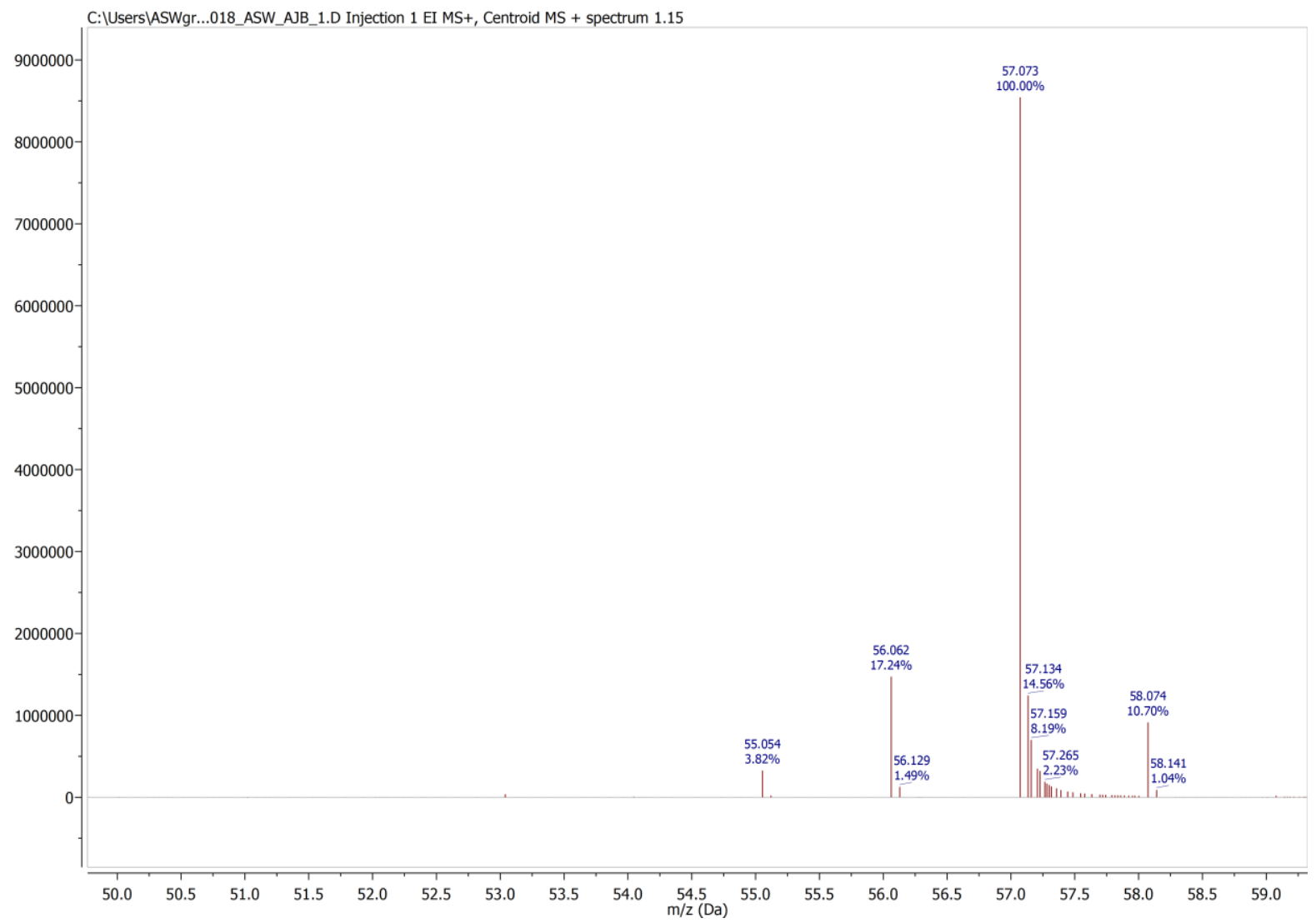

Figure S42: GC El-Mass spectrum of commercially bought isobutane- $\mathrm{H}_{10}$. Due to relative ease of fragmentation of isobutane, ${ }^{58}$ the molecular ion peak is that of $\mathrm{C}_{4} \mathrm{H}_{9}{ }^{+}$, $\mathrm{m} / \mathrm{z}=57.073$ (calc. 57.078).

Although approx. $10 \% \mathrm{C}_{4} \mathrm{H}_{10}{ }^{+}, \mathrm{m} / \mathrm{z}=58.074$ (calc. 58.078) can be located, in the experimental condition presented above, the percentage of $\mathrm{C}_{4} \mathrm{D}_{10}{ }^{+}$in the isobutane$d_{x}$ sample is below the detection intensity of the equipment, and hence cannot be unequivocally identified. 


\section{S.3.1.4. Simulated solution ${ }^{13} C\left\{{ }^{1} H\right\}$ NMR spectra of isobutane- $d_{x}(x=10-7)$}

The solution ${ }^{13} \mathrm{C}\left\{{ }^{1} \mathrm{H}\right\}$ NMR spectrum of isolated isobutane- $\mathrm{d}_{\mathrm{x}}(\mathrm{x}=10-7)$ (Figure S40) was de-convoluted using the Spin Simulation function on MestReNova, shown in Figure S43. The line width was kept at $6.0 \mathrm{~Hz}$ throughout, only changing the levels of population in each simulated environment.

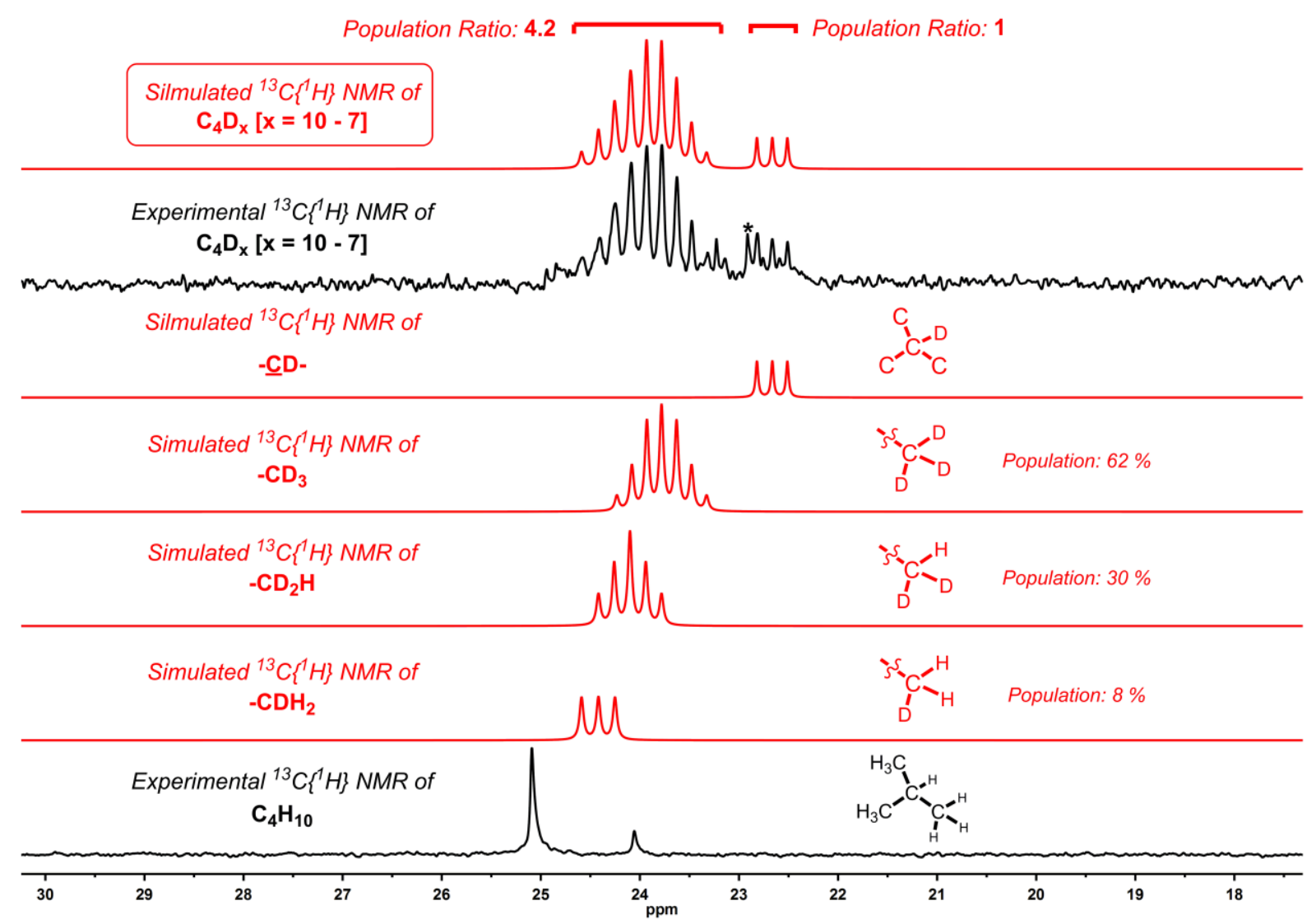

Figure S43: Simulated solution ${ }^{13} \mathrm{C}\left\{{ }^{1} \mathrm{H}\right\}$ NMR spectra of isobutane- $\mathrm{d}_{\mathrm{x}}(\mathrm{x}=10-7)$, showing approximated populations of varyingly level of deuteration in the $-\mathrm{CX}_{3}$ groups of isobutane. The signal marked by ${ }^{*}$ is from a pentane impurity.

Three systems were used to recreate the multiplet at $\delta 23.85$, modelling the ${ }^{13} \mathrm{C}$ methyl environments as $-\mathrm{CD}_{3},-\mathrm{CD}_{2} \mathrm{H}$ and $-\mathrm{CDH}_{2}$. No evidence of $-\mathrm{CH}_{3}$ could be seen in the experimental data so was not modelled. A separate fourth system was also modelled describing the triplet at $\delta 22.66$; reported as the methine carbon of isobutane- $d_{x}$, split by a single bound deuterium. The proto-methine group could not be modelled, as signals obscured by multiplet at $\delta 23.85$. 
The simulation suggests that $62 \%$ of the $-\mathrm{CX}_{3}$ groups were of $-\mathrm{CD}_{3}, 30 \%$ are $\mathrm{CD}_{2} \mathrm{H}$ and $8 \%$ are $-\mathrm{CDH}_{2}$. This is consistent with the GC El-MS shown in Figure S41, which showed a high proportion of $\mathrm{C}_{4} \mathrm{D}_{9}{ }^{+}$and $\mathrm{C}_{4} \mathrm{D}_{8}{ }^{+}$from the signals at 66.127 and 65.121 respectively as well as the molecular ion of $50.098^{+}$from $\mathrm{C}_{3} \mathrm{D}_{7}{ }^{+}$.

The population ratio of each ${ }^{13} \mathrm{C}$ environment in the simulated spectra was calculated from the sum of each individual $-\mathrm{CD}_{X} \mathrm{H}_{Y}$ component in each environment compared between the environments. These ratios suggest an approximate 1:4.2 ratio of carbon environments; albeit a little higher than predicted (1:3). This may be due to unmodelled $-\mathrm{C}-\mathrm{H}$ methine group's signals obscured by the multiplet at $\delta 23.85$, affecting this ratio.

\section{S.3.2. Solution-state deuteration of $\left[1-\mathrm{C}_{4} \mathrm{H}_{8}\right]\left[\mathrm{BAr}{ }_{4}\right]$}

A solution of $\left[1-\mathrm{C}_{4} \mathrm{H}_{8}\right]\left[B \mathrm{Br}_{4}{ }_{4}\right](10 \mathrm{mg})$ in $\mathrm{C}_{6} \mathrm{~F}_{2} \mathrm{H}_{4}$ in a thick walled NMR tube was freeze-pump-thaw degassed three times and backfilled with $D_{2}(1$ bar, $298 \mathrm{~K})$. Upon agitation the color of the solution changed from red to yellow. Solution ${ }^{31} \mathrm{P}\left\{{ }^{1} \mathrm{H}\right\} N M R$ showed total conversion of the organometallic fragment to be $\left[1-\mathbf{C}_{6} \mathbf{H}_{4} \mathbf{F}_{2}\right]\left[\mathbf{B} \mathbf{A r}_{4}{ }_{4}\right.$, where the volatile component was then isolated by trap-to-trap distillation. The products were identified as $\mathrm{C}_{4} \mathrm{H}_{8} \mathrm{D}_{2}$ by ${ }^{1} \mathrm{H}$ and ${ }^{2} \mathrm{H}$ NMR spectroscopy which is the product of deuteration across the double bond only.

${ }^{1} \mathrm{H} \mathrm{NMR}\left(\mathrm{CD}_{2} \mathrm{Cl}_{2}, 400 \mathrm{MHz}, 183 \mathrm{~K}\right): \delta 0.89(\mathrm{br} \mathrm{s}, \mathrm{CH})$.

${ }^{2} \mathrm{H} \mathrm{NMR}\left(\mathrm{CD}_{2} \mathrm{Cl}_{2}, 61 \mathrm{MHz}, 183 \mathrm{~K}\right): \delta 1.66$ (br s, 1D, CD), 0.85 (br s, 1D, CD). 


\section{S.3.3. Solid-state $\mathrm{H} / \mathrm{D}$ exchange on $\left[1-\mathrm{C}_{6} \mathrm{H}_{12}\right]\left[B \mathrm{Brr}_{4}\right]$}

\section{S.3.3.1. General Experimental of $H / D$ Exchange on [1- $\left.{ }_{6} \mathrm{H}_{12}\right]\left[B A r^{F}\right]$}

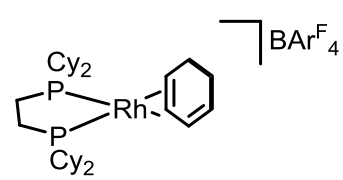

$\left[1-\mathrm{C}_{6} \mathrm{H}_{8}\right]\left[\mathrm{BAr}_{4}\right]$
$D_{2}$ $\underset{1 \text { bar, } 298 \mathrm{~K}}{\stackrel{\text { Solid-State }}{\longrightarrow}}$
90 minutes

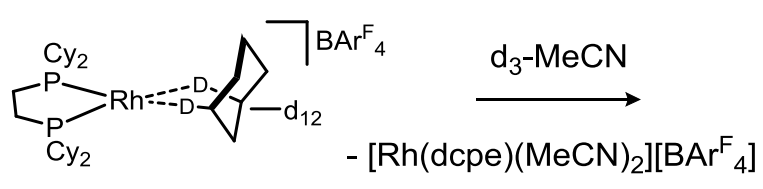

- $\left[\mathrm{Rh}(\mathrm{dcpe})(\mathrm{MeCN})_{2}\right]\left[\mathrm{BAr}_{4}\right]$

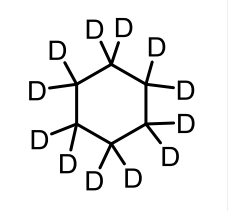

Cyclohexane-d $d_{12}$

A thick walled NMR tube was charge with powdered microcrystalline [1- $\left.\mathrm{C}_{6} \mathrm{H}_{8}\right]\left[\mathrm{BAr}{ }_{4}\right]$ $(10 \mathrm{mg}$ ) in an argon filled glove box. The sample was then cooled to $77 \mathrm{~K}$ in liquid nitrogen, evacuated and backfilled with $D_{2}(1$ bar, $298 \mathrm{~K})$. After 30 min, sample was then cooled again to $77 \mathrm{~K}$ in liquid nitrogen, evacuated and backfilled with $\mathrm{D}_{2}$ ( 1 bar, $298 \mathrm{~K})$. This cycle was repeated once more, to give a total of $3 \times 30$ mins cycles, totaling 90 minutes under $D_{2}$. The reaction was then quenched by condensing $d_{3}$ MeCN $(0.4 \mathrm{~mL})$ into the NMR tube. The volatiles were then isolated by trap-to-trap distillation.

${ }^{2} \mathrm{H} \mathrm{NMR}\left(\mathrm{d}_{3}-\mathrm{MeCN}, 61 \mathrm{MHz}\right): \delta 1.37(\mathrm{~s})$.

${ }^{13} \mathrm{C}\left\{{ }^{1} \mathrm{H}\right\}$ NMR $\left(\mathrm{d}_{3}-\mathrm{MeCN}, 126 \mathrm{MHz}\right): \delta 25.3\left(1: 2: 3: 2: 1\right.$ quintet, $\left.\mathrm{J}_{\mathrm{CD}}=19 \mathrm{~Hz}\right)$. 


\section{S.3.3.2. NMR Spectra}

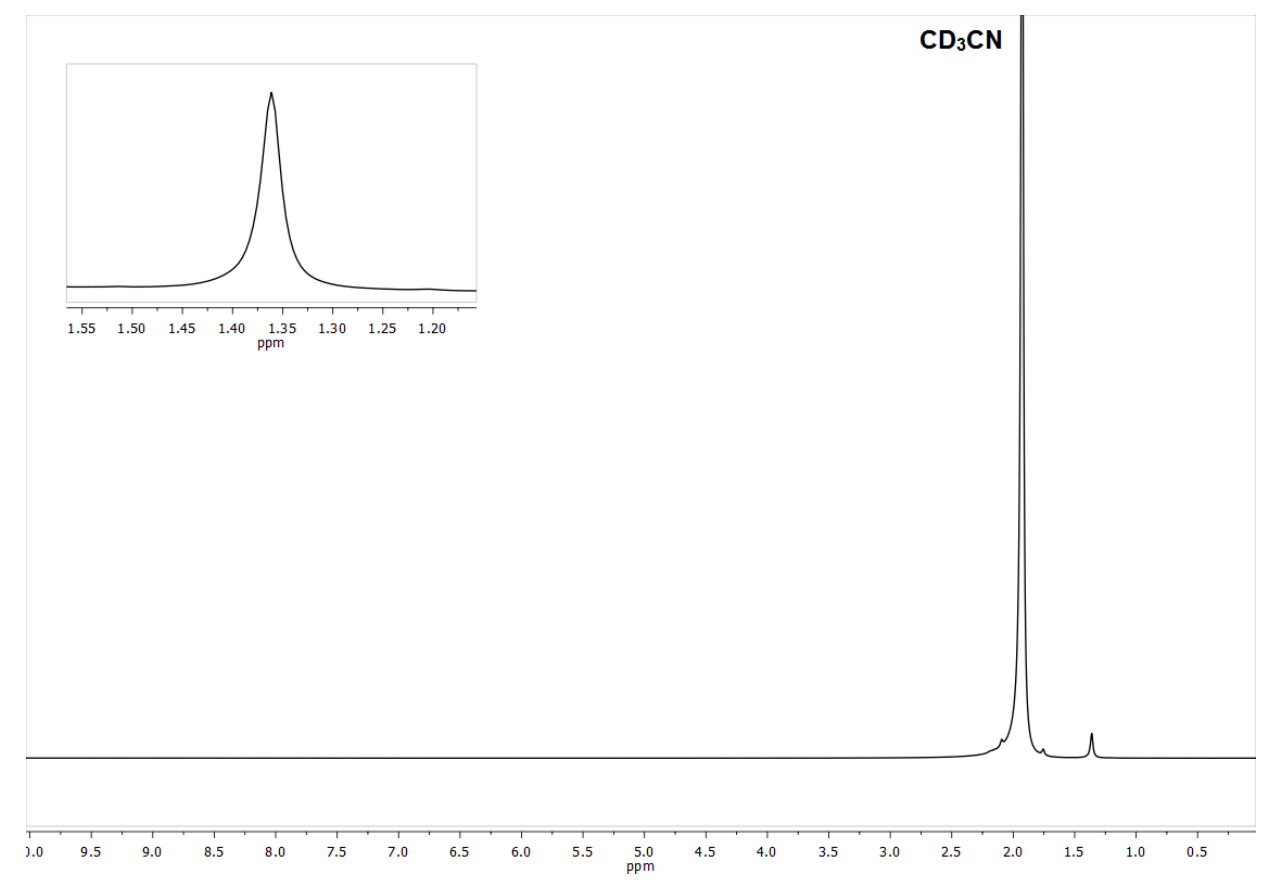

Figure S44: The solution ${ }^{2} \mathrm{H}$ NMR $\left(\mathrm{d}_{3}-\mathrm{MeCN}, 298 \mathrm{~K}, 61 \mathrm{MHz}\right)$ spectrum of cyclohexane- $\mathrm{d}_{12}$.

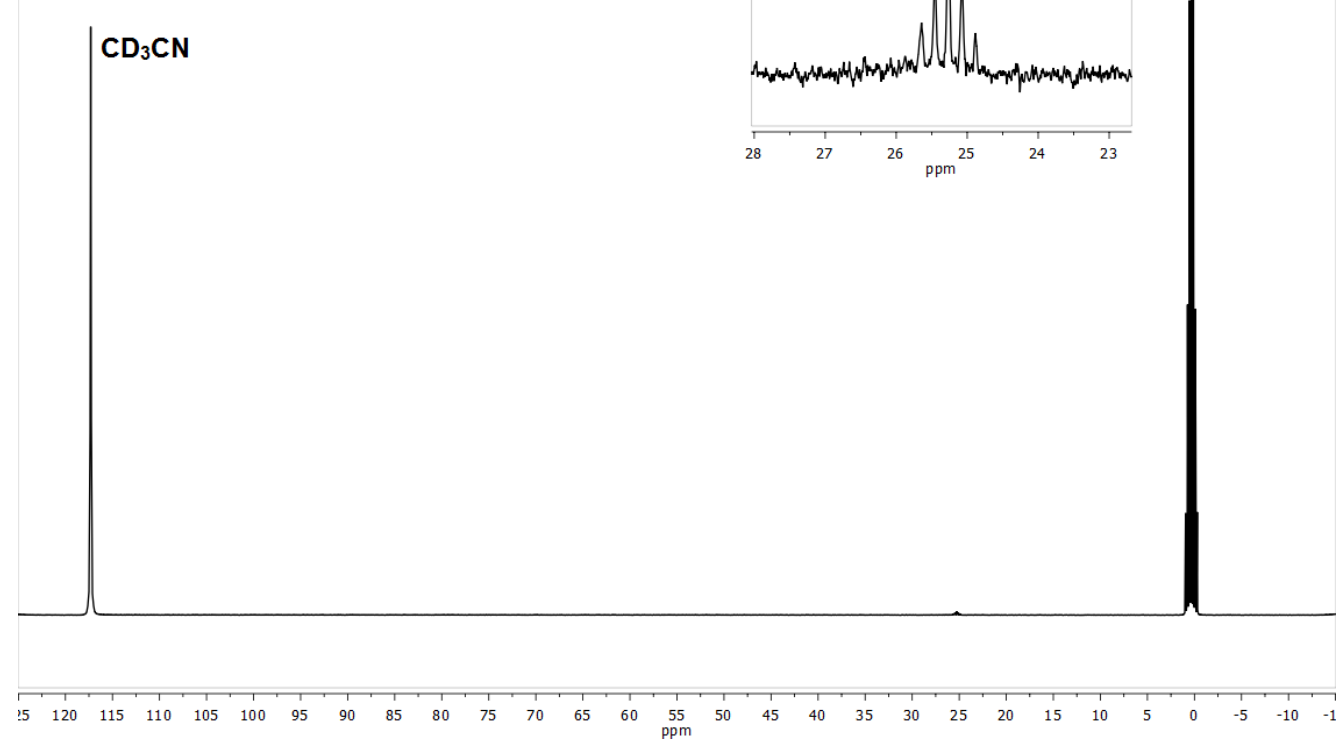

Figure S45: The solution ${ }^{13} \mathrm{C}\left\{{ }^{1} \mathrm{H}\right\}$ NMR $\left(\mathrm{d}_{3}-\mathrm{MeCN}, 298 \mathrm{~K}, 100 \mathrm{MHz}\right)$ spectrum of cyclohexane- $d_{12}$, $\delta 25.3\left(1: 2: 3: 2: 1\right.$ quintet, $\left.\mathrm{J}_{\mathrm{CD}}=19 \mathrm{~Hz}\right)$. 


\section{S.3.3.3. GC El-Mass spectra}
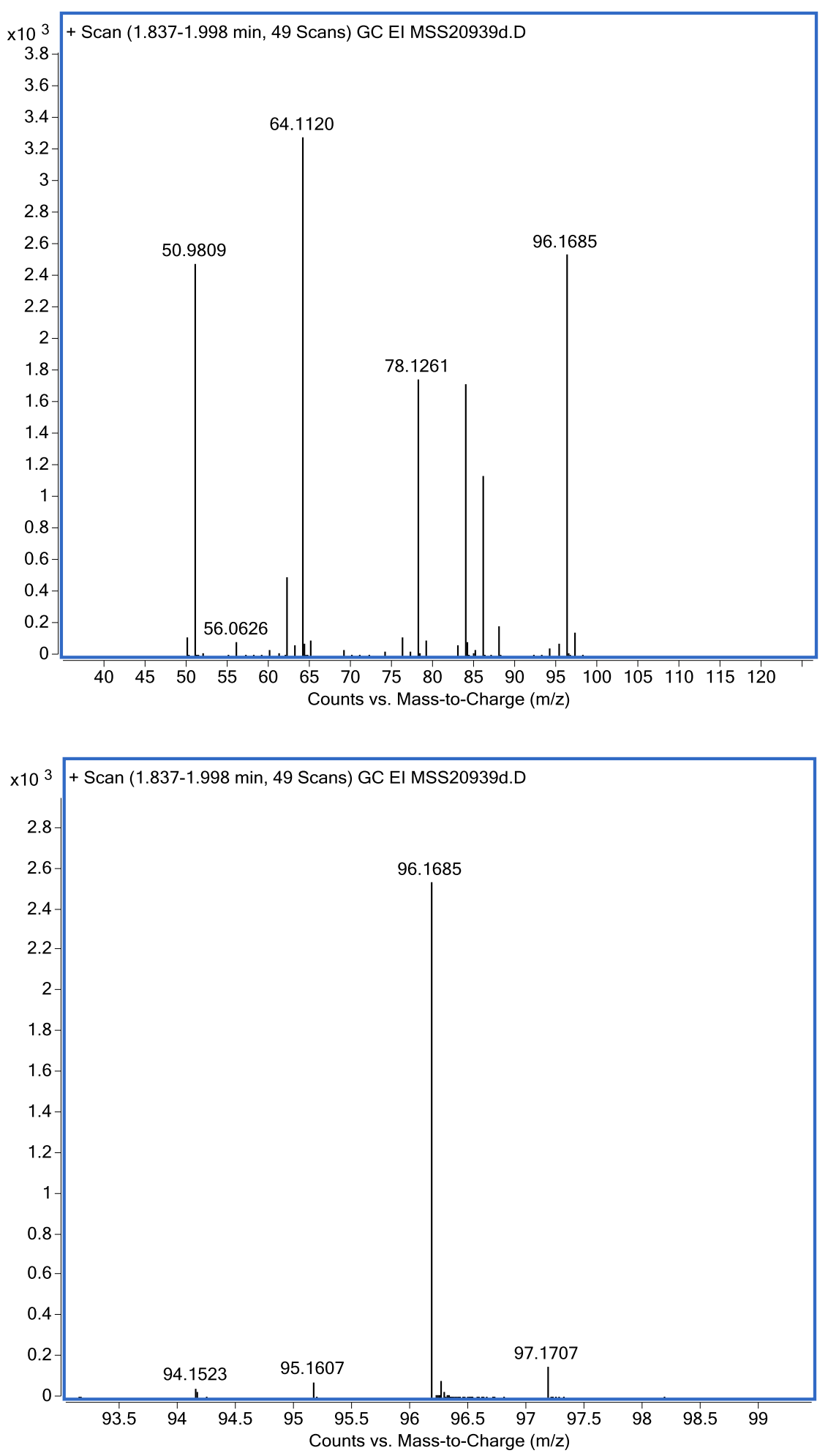

Figure S46: Mass spectrum of the isolated volatiles where the time of $D_{2}$ exposure was 30 minutes per cycle (top). Enlargement of $\mathrm{m} / \mathrm{z}=93-100$ region (bottom). The signal at $\mathrm{m} / \mathrm{z}=96.1685$ matches that of $\mathrm{C}_{6} \mathrm{D}_{12}$ (calc. 96.1687). Signals at $\mathrm{m} / \mathrm{z}=84$ and 86 are due to $\mathrm{CH}_{2} \mathrm{Cl}_{2}$. 

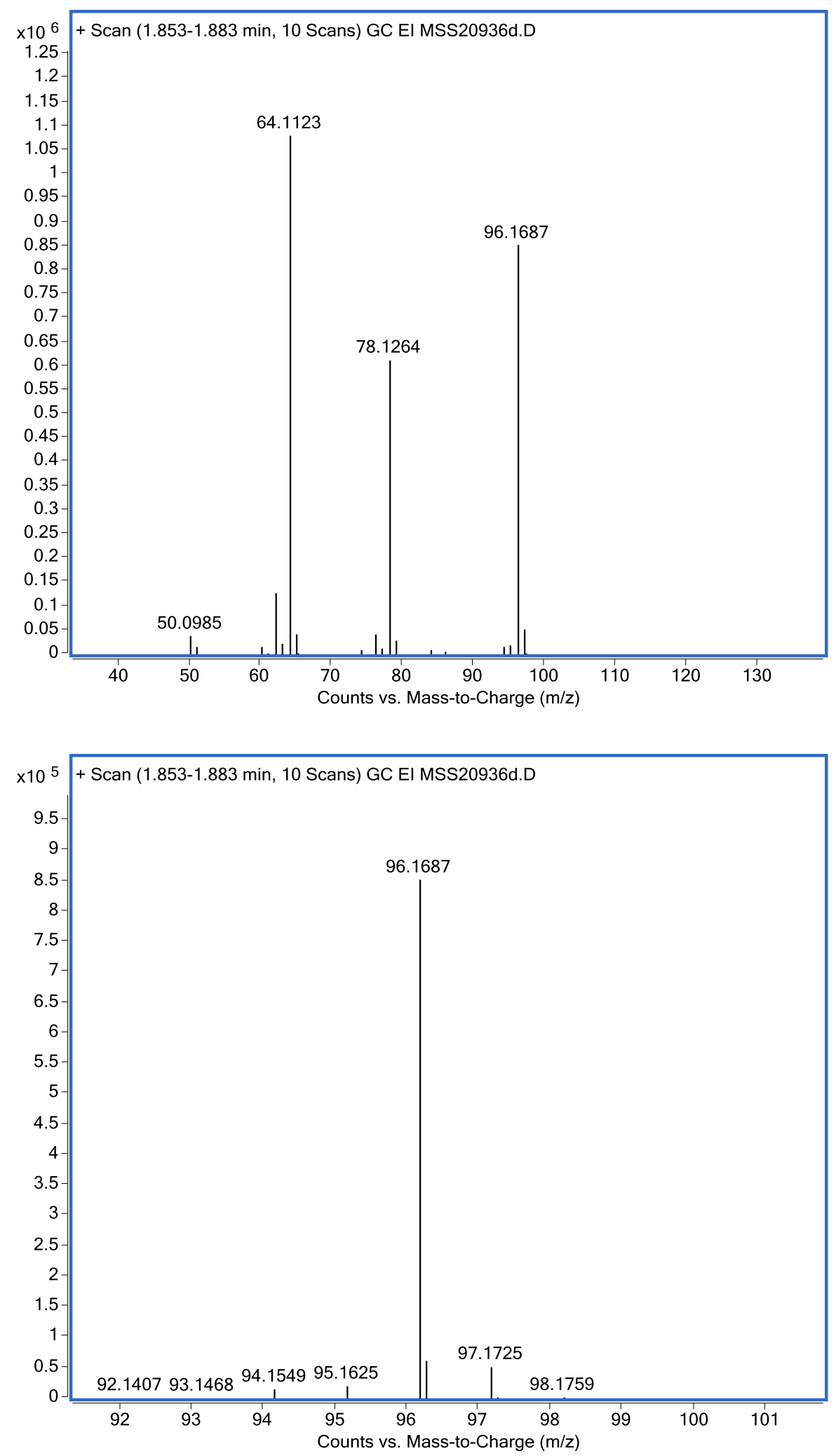

Figure S47: Mass spectrum of a commercially sourced sample of $D_{12}$-cyclohexane (top). Enlargement of $\mathrm{m} / \mathrm{z}=91-100$ region (bottom). 

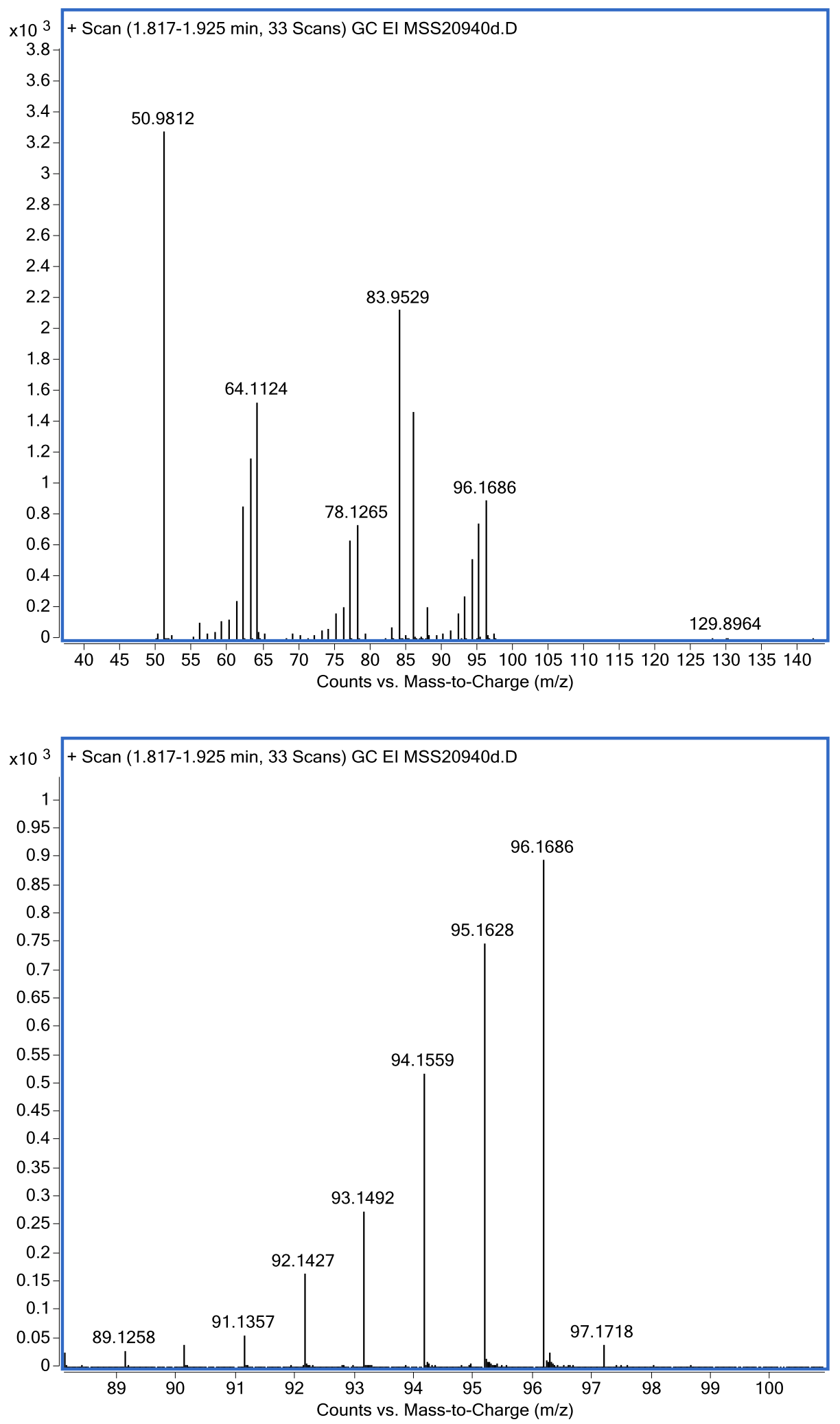

Figure S48: Mass spectrum of the isolated volatiles where the time of $D_{2}$ exposure was 5 minutes per cycle rather than 30 minutes (top). Enlargement of $\mathrm{m} / \mathrm{z}=88-100$ region (bottom). Signals at $\mathrm{m} / \mathrm{z}=84$ and 86 are due to $\mathrm{CD}_{2} \mathrm{Cl}_{2}$. 

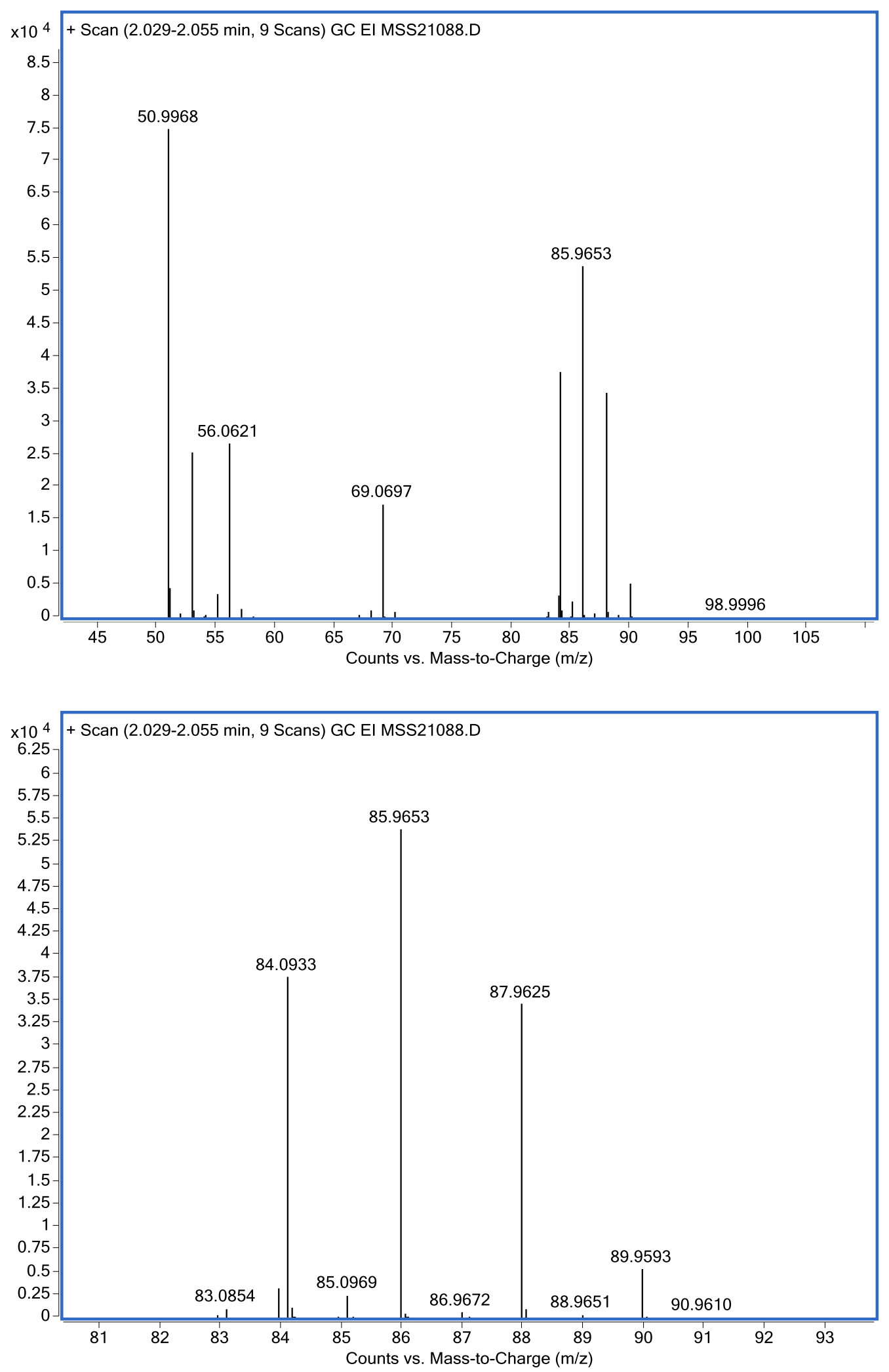

Figure S49: Mass spectrum of the isolated volatiles where the time of $D_{2}$ exposure was 0 minutes per cycle rather than 30 minutes (top), i.e., no $D_{2}$ exposure. Enlargement of $\mathrm{m} / \mathrm{z}=81-93$ region (bottom). The signal at $\mathrm{m} / \mathrm{z}=84.0933$ matches that of $\mathrm{C}_{6} \mathrm{H}_{12}$ (calc. 84.0933). Signals at $\mathrm{m} / \mathrm{z}=86$ and 88 are due to $\mathrm{CD}_{2} \mathrm{Cl}_{2}$. 

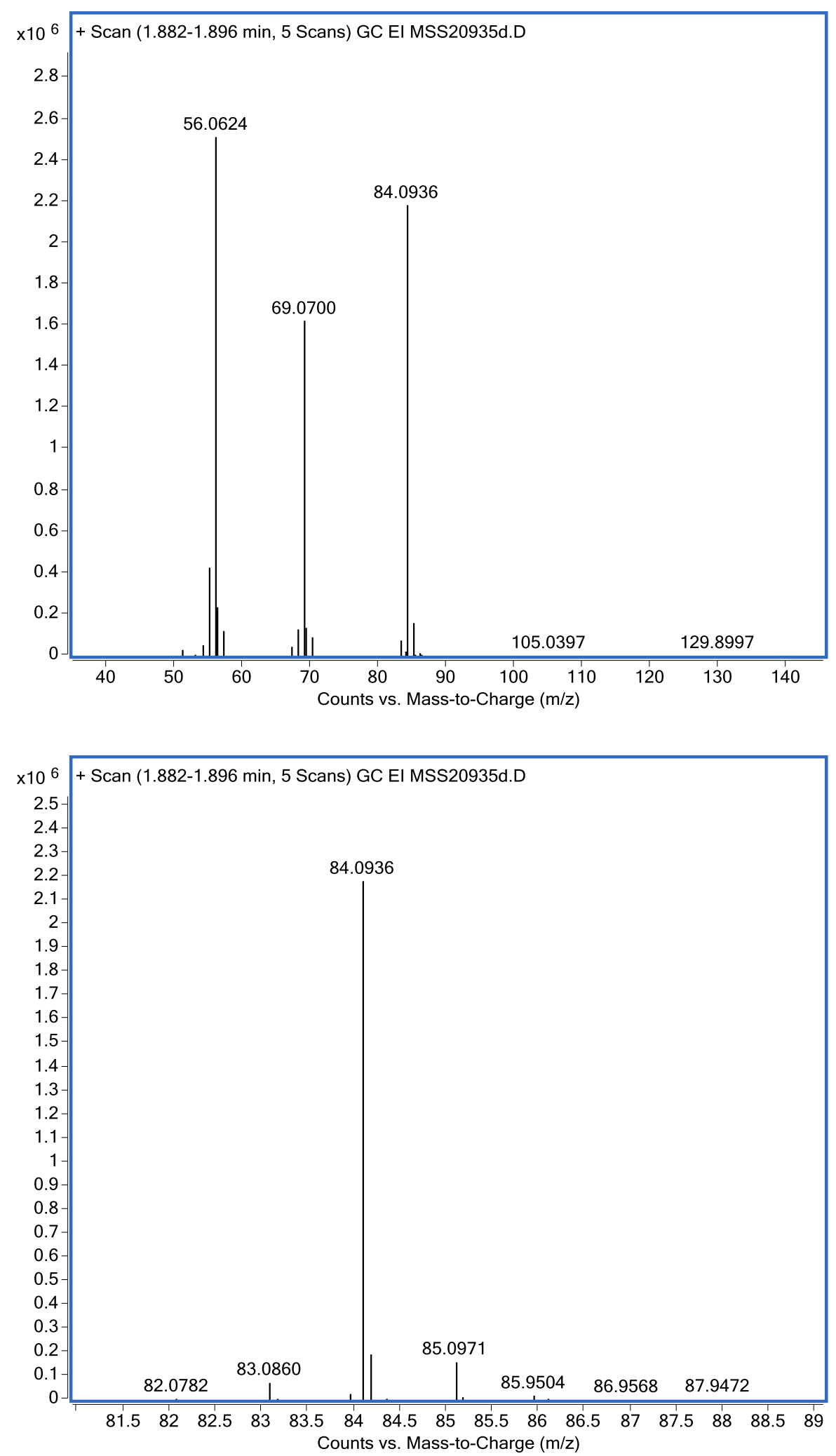

Figure S50: Mass spectrum of a commercially sourced sample of cyclohexane (top). Enlargement of $\mathrm{m} / \mathrm{z}=81-89$ region (bottom). 


\section{S.3.4. Solution-state deuteration of $\left[1-\mathrm{C}_{6} \mathrm{H}_{8}\right]\left[\mathrm{BAr}_{4}\right]$}

\section{S.3.4.1. Procedure for the solution-state deuteration of $\left[1-\mathrm{C}_{6} \mathrm{H}_{8}\right]\left[\mathrm{BAr}{ }_{4}\right]$}

A solution of $\left[1-\mathrm{C}_{6} \mathrm{H}_{8}\right]\left[\mathrm{BAr}_{4}{ }_{4}\right.$ (10 mg) in $\mathrm{CD}_{2} \mathrm{Cl}_{2}$ in a thick walled NMR tube was freeze-pump-thaw degassed three times and backfilled with $D_{2}(1$ bar, $298 \mathrm{~K})$. Upon agitation the color of the solution changed from red to yellow. The volatile component was then isolated by trap-to-trap distillation. The product was identified as $\mathrm{C}_{6} \mathrm{H}_{8} \mathrm{D}_{4}$, which is the product of deuteration across the double bonds only.

${ }^{1} \mathrm{H} \mathrm{NMR}\left(\mathrm{CD}_{2} \mathrm{Cl}_{2}, 400 \mathrm{MHz}, 183 \mathrm{~K}\right): \delta 1.52$ (br s, 4H, CH), 1.05 (br s, 4H, CH).

${ }^{2} \mathrm{H}$ NMR $\left(\mathrm{CD}_{2} \mathrm{Cl}_{2}, 61 \mathrm{MHz}, 183 \mathrm{~K}\right): \delta 1.54$ (br s, 2D, CD), 1.08 (br s, 2D, CD). 


\section{S.3.4.2. GC El-Mass Spectra}
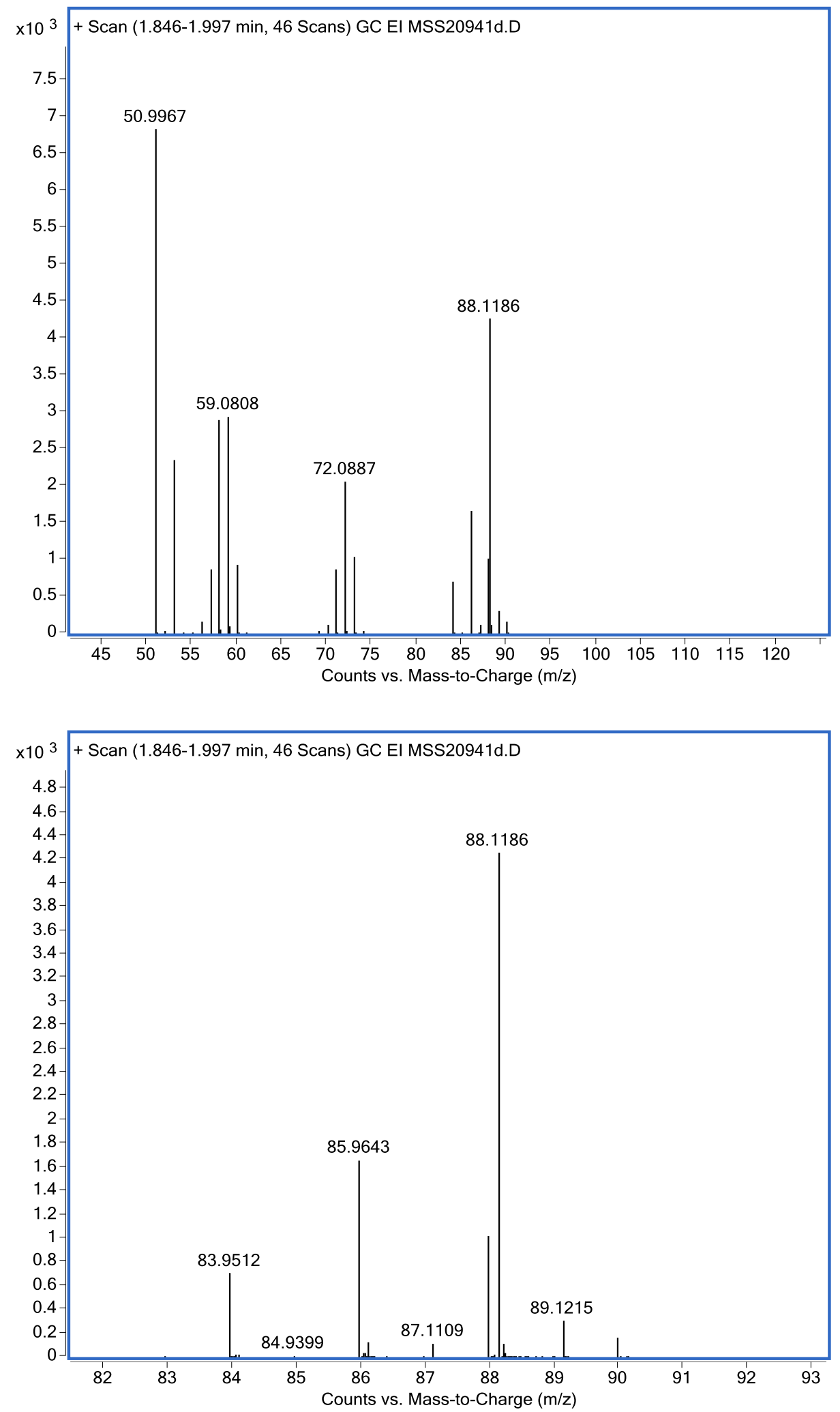

Figure S51: Mass spectrum of the isolated volatiles (top). Enlargement of $\mathrm{m} / \mathrm{z}=81-$ 89 region (bottom). The signal at $\mathrm{m} / \mathrm{z}=88.1186$ matches that of $\mathrm{C}_{6} \mathrm{H}_{8} \mathrm{D}_{4}{ }^{+}$(calc. 88.1185). Signals at $\mathrm{m} / \mathrm{z}=84$ and 86 are due to $\mathrm{CH}_{2} \mathrm{Cl}_{2}$. 


\section{S.4. Alkane Dehydrogenation Experiments}

\section{S.4.1. Dehydrogenation of $\left[1-\mathrm{C}_{4} \mathrm{H}_{10}\right]\left[B \mathrm{Br}_{4}{ }_{4}\right]$ to form $\left[1-\mathrm{C}_{4} \mathrm{H}_{8}\right]\left[B \mathrm{Br}_{4}{ }_{4}\right]$}

\section{S.4.1.1. Solid-state dehydrogenation of $\left[1-\mathrm{C}_{4} \mathrm{H}_{10}\right]\left[B A \mathrm{Br}_{4}\right]$ under argon flow to form $\left[1-\mathrm{C}_{4} \mathrm{H}_{8}\right]\left[\mathrm{BAr}{ }_{4}\right]$}

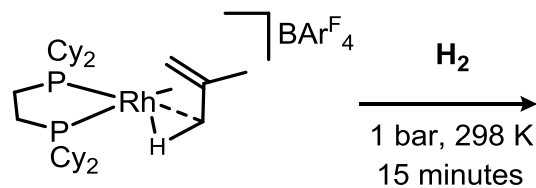

$\left[1-\mathrm{C}_{4} \mathrm{H}_{8}\right]\left[\mathrm{BAr}{ }_{4}\right]$

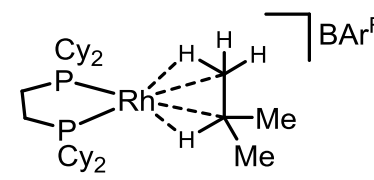

$\left[1-\mathrm{C}_{4} \mathrm{H}_{10}\right]\left[\mathrm{BAr}_{4}\right]$

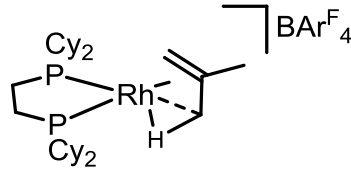

$\left[1-\mathrm{C}_{4} \mathrm{H}_{8}\right]\left[\mathrm{BArF}_{4}\right]$

A J Young flask (ca. $50 \mathrm{~mL}$ ) was charged with $50 \mathrm{mgs}$ of block like crystalline

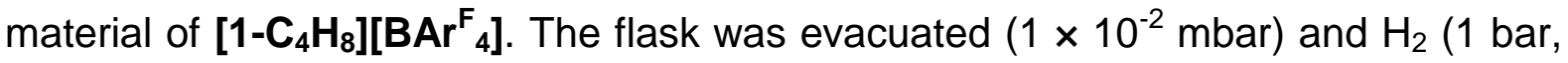
$298 \mathrm{~K}$ ) was added for 15 minutes; to yield deep red coloured crystallites of [1$\left.\mathrm{C}_{4} \mathrm{H}_{10}\right]\left[\mathrm{BAr}_{4}{ }_{4}\right]$.

A portion of this (approx. $10 \mathrm{mgs}$ ) was taken at this point, dissolved in $\mathrm{CH}_{2} \mathrm{Cl}_{2}$ and solution ${ }^{31} \mathrm{P}\left\{{ }^{1} \mathrm{H}\right\}$ NMR spectrum taken. No signals relating to [1- $\left.\mathrm{C}_{4} \mathrm{H}_{8}\right]\left[\mathrm{BAr} \mathrm{F}_{4}\right]$ could be identified, only signals relating to $\left[1-\mathrm{BAr}_{4}{ }_{4}\right]$ and further solvent activated complexes - confirming the hydrogenation of total $\left[1-\mathrm{C}_{4} \mathrm{H}_{8}\right]\left[\mathrm{BAr}_{4}{ }_{4}\right]$ had occurred.

The remaining solid was placed under an argon flow for 4 hours. This was done by placing an exit needle into the suba sealed $\mathrm{J}$ Young flask which was open to argon flow, with regulator pressure set at 0.5 bar. After 4 hours, the sample was sealed, transferred to a glove box and packed inside a solid state NMR rotor and analyzed ${ }^{31} \mathrm{P}\left\{{ }^{1} \mathrm{H}\right\}$ and ${ }^{13} \mathrm{C}\left\{{ }^{1} \mathrm{H}\right\}$ solid state NMR spectroscopy. 


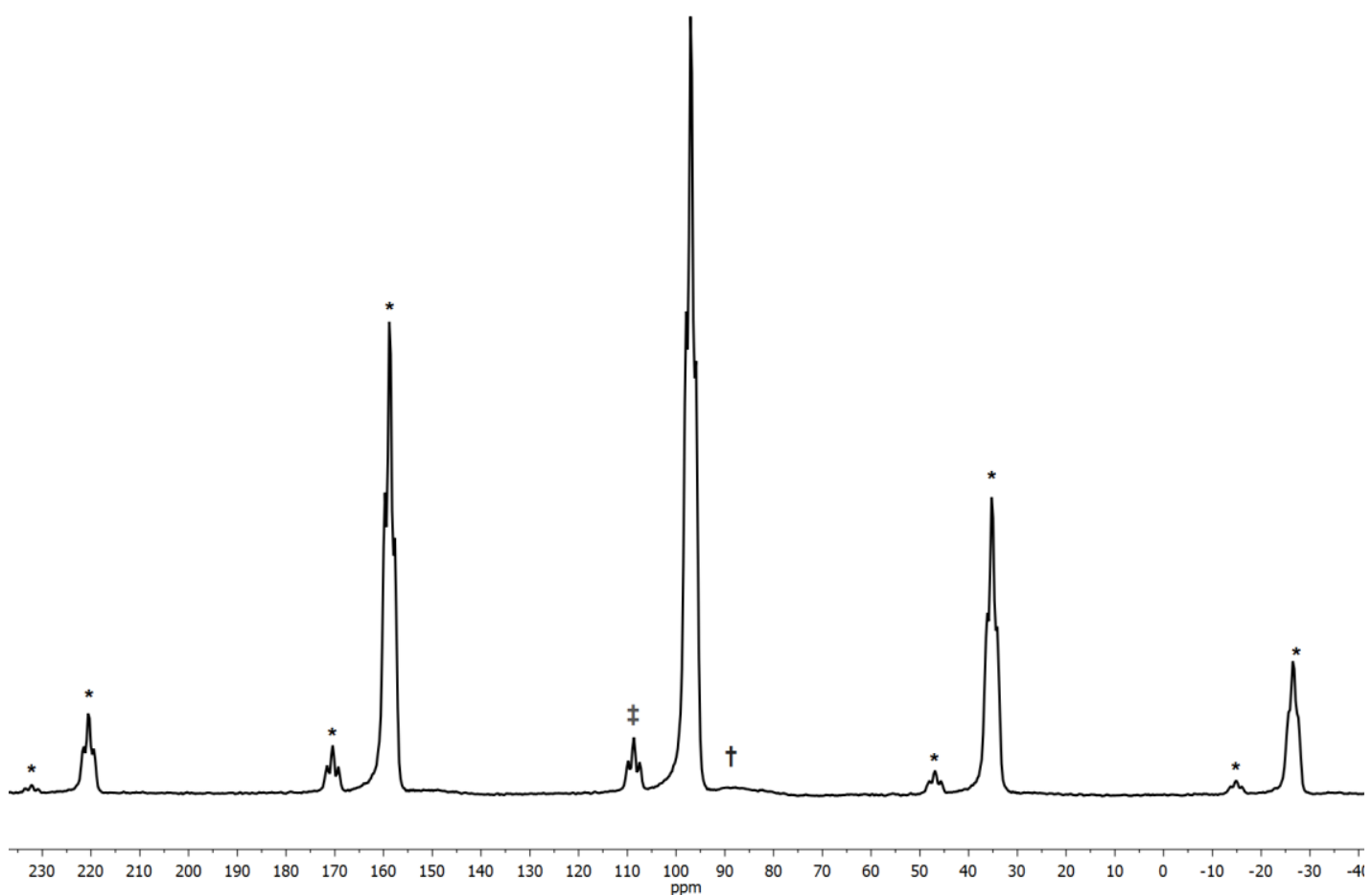

Figure S52: The ${ }^{31} \mathrm{P}\left\{{ }^{1} \mathrm{H}\right\}$ SSNMR (162 MHz, $295 \mathrm{~K}, 10 \mathrm{kHz}$ spin rate) spectrum of the dehydrogenation of powdered microcrystalline $\left[1-\mathbf{C}_{4} \mathbf{H}_{10}\right]\left[\mathrm{BAr}_{4}{ }_{4}\right]$ under argon flow to form $\left[1-\mathrm{C}_{4} \mathrm{H}_{8}\right]\left[\mathrm{BAr}_{4}\right]$ (approx. $90 \%$ ). The rotor is packed under an argon atmosphere. The resonances $\ddagger$ marked are assigned to $\left[\mathbf{1}-\mathbf{C}_{4} \mathbf{H}_{10}\right]\left[B \mathbf{A r}_{4}\right]$ (approx. $7 \%$ ), from incomplete dehydrogenation and the resonances marked $\dagger$ are assigned to the decomposition product of [1-BAr $\left.{ }_{4}\right]^{\mathrm{S} 2}$ (approx. $3 \%$ ), formed during the initial hydrogenation. The resonances marked * are due to spinning sidebands. 


\section{S.4.1.2. Kinetics of the solid-state $\left[1-\mathrm{C}_{4} \mathrm{H}_{10}\right]\left[\mathrm{BAr}{ }_{4}{ }_{4}\right]$ dehydrogenation under}

vacuum to form $\left[1-\mathrm{C}_{4} \mathrm{H}_{8}\right]\left[\mathrm{BAr}_{4}{ }^{\mathrm{F}}\right]$
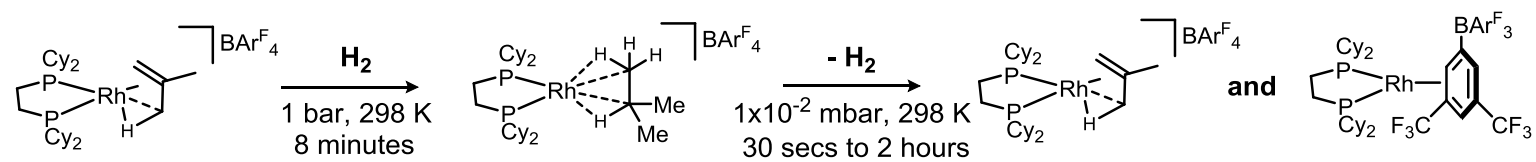

$\left[1-\mathrm{C}_{4} \mathrm{H}_{8}\right]\left[\mathrm{BAr}_{4}\right]$

$\left[1-\mathrm{C}_{4} \mathrm{H}_{10}\right]\left[\mathrm{BAr}_{4}\right]$ \begin{tabular}{c|c} 
Left under $\mathrm{H}_{2}$ & Dissolved after \\
for 90 mins & no vacuum
\end{tabular}

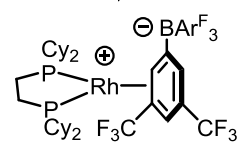

[1-BArF ${ }_{4}$ ]

\section{[1- $\left.\mathrm{C}_{4} \mathrm{H}_{8}\right]\left[\mathrm{BAr}_{4}\right]$}

${ }^{31} \mathrm{P}\left\{{ }^{1} \mathrm{H}\right\}=95 \mathrm{ppm}$ $\mathrm{J}_{\mathrm{RhP}}=179 \mathrm{~Hz}$

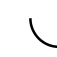

Concentration of $\left[1-\mathrm{C}_{4} \mathrm{H}_{8}\right]\left[B \mathrm{Br}^{\mathrm{F}}\right.$ ] could be measured against known standard of $\mathrm{PPh}_{3}$ in acetone.

A J Young NMR tube ( $2.1 \mathrm{~mL}$ ) was charged with 10 mgs powdered crystalline material of $\left[1-\mathbf{C}_{4} \mathrm{H}_{8}\right]\left[\mathrm{BAr}_{4}\right]$. The tube was evacuated $\left(1 \times 10^{-2} \mathrm{mbar}\right)$ and $\mathrm{H}_{2}(1 \mathrm{bar}$, $298 \mathrm{~K}$ ) was added for 8 minutes to yield deep red powder of [1-C $\left.{ }_{4} \mathbf{H}_{10}\right]\left[\mathrm{BAr}_{4}\right]$. The samples were placed under vacuum $\left(1 \times 10^{-2} \mathrm{mbar}\right)$ for varying times between 0 seconds and 2 hours, then dissolved in $\mathrm{CD}_{2} \mathrm{Cl}_{2}$ and analyzed by ${ }^{31} \mathrm{P}\left\{{ }^{1} \mathrm{H}\right\}$ NMR spectroscopy.

The above procedure was repeated on numerous occasions, varying the period of time the sample was exposed to vacuum at room temperature. When time $=0$ seconds, no signals relating to $\left[1-\mathrm{C}_{4} \mathrm{H}_{8}\right]\left[\mathrm{BAr}_{4}{ }_{4}\right]$ could be identified, confirming the complete hydrogenation of the sample.

After dissolution in $\mathrm{CD}_{2} \mathrm{Cl}_{2}$, two doublets were observed in the ${ }^{31} \mathrm{P}\left\{{ }^{1} \mathrm{H}\right\}$ NMR spectra

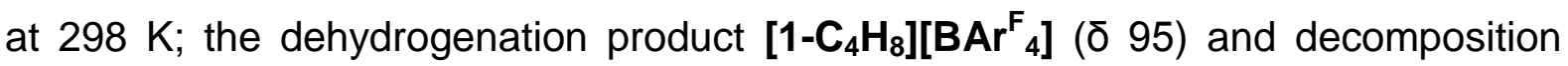
product [1-BAr $\left.{ }_{4}\right]^{\mathrm{S} 2}(\delta 91)$. The concentration of re-formed [1- $\left.\mathbf{C}_{4} \mathrm{H}_{8}\right]\left[\mathrm{BAr}{ }_{4}{ }_{4}\right.$ could be accurately measured by use of an separate, sealed capillary of $\mathrm{PPh}_{3}$ in acetone. 


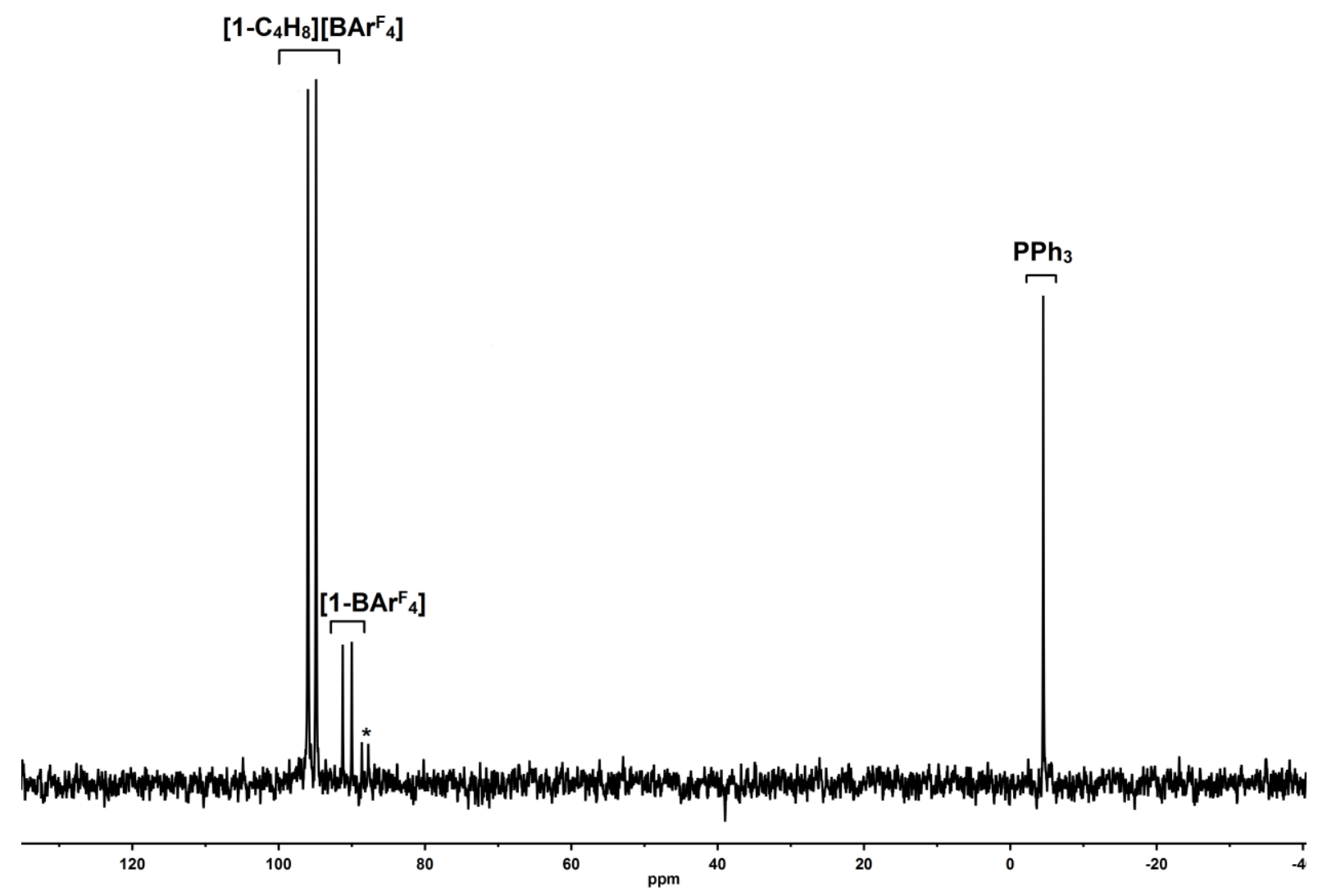

Figure S53: Example of a solution ${ }^{31} \mathrm{P}\left\{{ }^{1} \mathrm{H}\right\} \mathrm{NMR}\left(\mathrm{CD}_{2} \mathrm{Cl}_{2}, 298 \mathrm{~K}, 162 \mathrm{MHz}\right)$ spectra of the dehydrogenation of [1- $\left.\mathrm{C}_{4} \mathrm{H}_{8}\right]\left[\mathrm{BAr}_{4} \mathrm{~F}_{4}\right]$ under vacuum for 1 hour. Signals can be

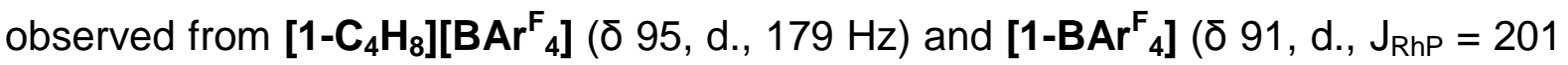
$\mathrm{Hz})$ with $\mathrm{PPh}_{3}\left(\delta-6\right.$, in acetone within sealed capillary). ${ }^{*}=\mathrm{a}$ further, unidentified $\mathrm{CH}_{2} \mathrm{Cl}_{2}$ decomposition product of [1-BAr ${ }_{4}{ }^{\mathrm{S}}$. ${ }^{\mathrm{S}}$ 


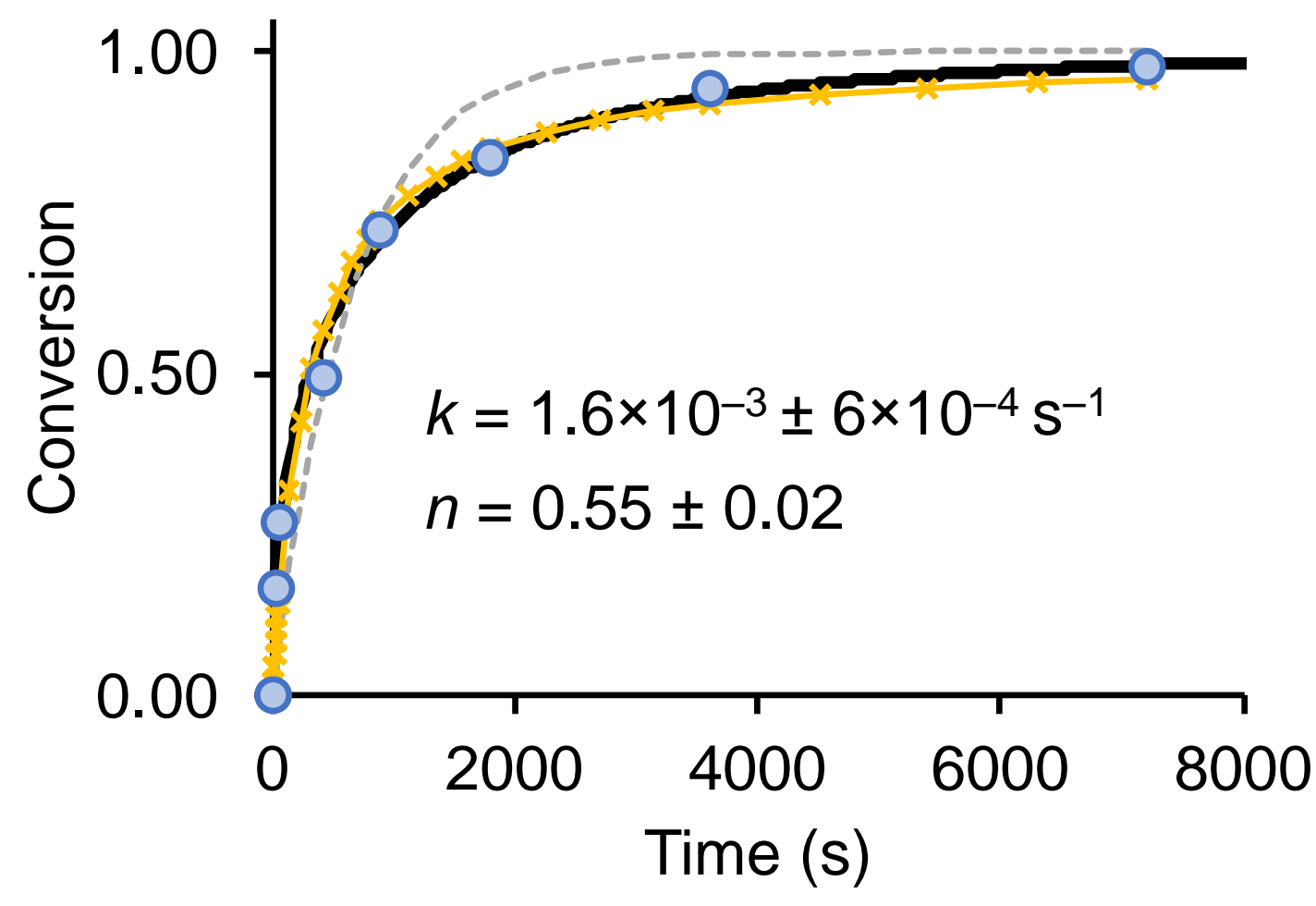

Modified Avrami COPASI 1st Order
O Experimental

* COPASI 2nd Order

Figure S54: Modified JAMK Plot of Conversion ${ }^{S 9}(f)=\left(1-e^{(-k t) n}\right)$ versus time for the dehydrogenation of $\left[1-\mathbf{C}_{4} \mathrm{H}_{10}\right]\left[\mathrm{BAr}{ }_{4}\right]$ to $\left[1-\mathbf{C}_{4} \mathrm{H}_{8}\right]\left[B \mathrm{Brr}_{4}\right]$ in the solid-state. Where $k=$ growth rate constant and $n=$ Avrami exponent.

Shown with comparison to a $\mathrm{COPASI}^{\mathrm{S} 10}$ modelled first order process for dehydrogenation $\left(\left[1-\mathrm{C}_{4} \mathrm{H}_{10}\right]\left[\mathrm{BAr}_{4}\right] \rightarrow\left[1-\mathrm{C}_{4} \mathrm{H}_{8}\right]\left[\mathrm{BAr}_{4}{ }_{4}\right], k=1.5(2) \times 10^{-3} \mathrm{~s}^{-1}\right)$ and a second order process $\left(2 \times\left[1-\mathrm{C}_{4} \mathrm{H}_{10}\right]\left[\mathrm{BAr}{ }_{4}\right] \rightarrow\left[1-\mathrm{C}_{4} \mathrm{H}_{8}\right]\left[B \mathrm{Brr}_{4}\right]+\left[1-\mathrm{C}_{4} \mathrm{H}_{10}\right]\left[B A \mathrm{Br}_{4}\right]\right.$, $k=1.6(2) \times 10^{-4} \mathrm{M}^{-1} \mathrm{~s}^{-1}$ ). Initial concentration of dissolved samples $=19.8 \mathrm{mM}$ (conversion $=0 \%$ ). 


\section{S.4.1.3. Single-Crystal to Single-Crystal dehydrogenation of [1- $\left.\mathrm{C}_{4} \mathrm{H}_{10}\right]\left[\mathrm{BAr}{ }_{4}\right]$ under vacuum to form $\left[1-\mathrm{C}_{4} \mathrm{H}_{8}\right]\left[\mathrm{BAr}_{4}\right]$ for an $\mathrm{x}$-ray diffraction study}

A J Young NMR tube ( $2 \mathrm{~mL}$ ) was charged with $10 \mathrm{mgs}$ of orange coloured, block like crystalline material of [1- $\left.\mathrm{C}_{4} \mathrm{H}_{8}\right]\left[\mathrm{BAr}_{4}{ }_{4}\right.$. The flask was evacuated $\left(1 \times 10^{-2} \mathrm{mbar}\right)$ and $\mathrm{H}_{2}$ (1 bar, $298 \mathrm{~K}$ ) was added for 15 minutes to yield deep red crystallites of [1$\mathrm{C}_{4} \mathrm{H}_{10}$ ][BAr${ }_{4}$ ]. The sample was then placed under vacuum $\left(2 \times 10^{-2} \mathrm{mbar}\right)$ for 4 hours, to which the colour of the crystals after this time had returned to orange.

The crystalline material was then coated with Fomblin $®$ Y oil under an argon flush, a suitable crystal was rapid selected and then transferred to the cryostream of a diffractometer and an x-ray diffraction study was undertaken.

The crystals were of sufficient quality to be collected, and solved, as [1$\mathrm{C}_{4} \mathrm{H}_{8}$ ][BAr ${ }_{4}$ ]-SC-SC. For further details of the structural study, please refer to section S.5. 


\section{S.4.2. Dedeuteration of $\left[1-C_{4} D_{x}\right.$-alkane] $\left[B A r^{F}\right]$ under vacuum to form $\left[1-C_{4} D_{x}-\right.$}

alkene][BAr ${ }_{4}$ ]

S.4.2.1. Solid state dedeuteration of [1-C $C_{4} D_{x}$-alkane][BAr$\left.{ }_{4}\right]$ under vacuum to form [1-C $\mathrm{C}_{4} \mathrm{D}_{\mathrm{x}}$-alkene][BAr$\left.{ }_{4}{ }_{4}\right]$

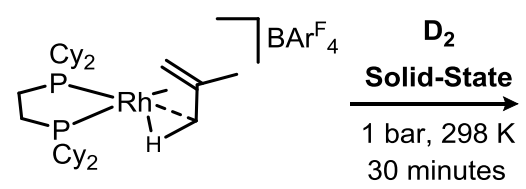

$\left[1-\mathrm{C}_{4} \mathrm{H}_{8}\right]\left[\mathrm{BAr}_{4}\right]$

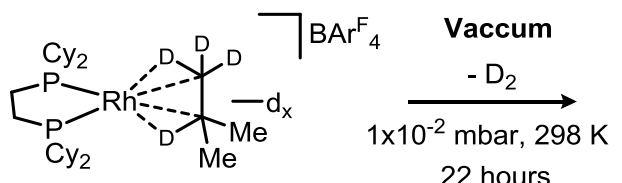

$\left[1-\mathrm{C}_{4} \mathrm{D}_{\mathrm{x}}\right.$-alkane][BArF$\left.{ }_{4}\right]$

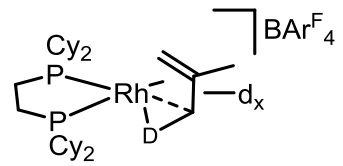

$\left[1-\mathrm{C}_{4} \mathrm{D}_{\mathrm{x}}\right.$-alkene][BAr $\left.\mathrm{F}_{4}\right]$

A J Young NMR tube $(\sim 3 \mathrm{~mL})$ was charged $30 \mathrm{mgs}$ of block-like crystallites of [1$\left.\mathrm{C}_{4} \mathrm{H}_{8}\right]\left[\mathrm{BAr}_{4}{ }_{4}\right.$ ]. The flask was evacuated $\left(1 \times 10^{-2} \mathrm{mbar}\right)$ and $\mathrm{D}_{2}(1 \mathrm{bar}, 298 \mathrm{~K})$ was added to yield red crystalline powder of $\left[1-C_{4} D_{x}\right.$-alkane][BAr $\left.{ }_{4}\right]$, and left for 30 minutes. After this time, the sample was placed under vacuum at room temperature for 22 hours to yield [1-C $\mathbf{C}_{4} \mathrm{D}_{\mathrm{x}}$-alkene][BAr${ }_{4}{ }_{4}$, where $(x=8-6)$.

\section{S.4.2.2. Characterization data for $\left[1-C_{4} D_{x}\right.$-alkene][BAr $\left.{ }_{4}\right]$}

${ }^{1} \mathrm{H}$ NMR $\left(\mathrm{CD}_{2} \mathrm{Cl}_{2}, 298 \mathrm{~K}, 400 \mathrm{MHz}\right): \delta 7.73$ (s, 8H, ortho-ArH), 7.57 (s, 4H, para$\mathrm{ArH}), 5.32\left(\mathrm{CDHCl}_{2}\right), 2.09-1.64$ (br m, 24H, overlapping aliphatic $\mathrm{CH}$ ), 1.40-1.0.96 (br $\mathrm{m}, 2 \mathrm{OH}$, overlapping aliphatic $\mathrm{CH}$ ).

${ }^{1} \mathrm{H}$ NMR $\left(\mathrm{CD}_{2} \mathrm{Cl}_{2}, 183 \mathrm{~K}, 400 \mathrm{MHz}\right): \delta 7.75$ (s, 8H, ortho-ArH), 7.56 (s, $4 \mathrm{H}$, para$\mathrm{ArH}), 5.32\left(\mathrm{CDHCl}_{2}\right), 2.22-1.38$ (br m, $24 \mathrm{H}$, overlapping aliphatic $\left.\mathrm{CH}\right), 1.38-0.63$ (br $\mathrm{m}, 24 \mathrm{H}$, overlapping aliphatic $\mathrm{CH}$ ).

${ }^{2} \mathrm{H}$ NMR $\left(\mathrm{CD}_{2} \mathrm{Cl}_{2}, 298 \mathrm{~K}, 400 \mathrm{MHz}\right): \delta 1.55$ (br. s)

${ }^{2} \mathrm{H} \mathrm{NMR}\left(\mathrm{CD}_{2} \mathrm{Cl}_{2}, 183 \mathrm{~K}, 400 \mathrm{MHz}\right): \delta 0.72$ (br. m)

${ }^{31} \mathrm{P}\left\{{ }^{1} \mathrm{H}\right\} \mathrm{NMR}\left(\mathrm{CD}_{2} \mathrm{Cl}_{2}, 298 \mathrm{~K}, 162 \mathrm{MHz}\right): \delta 95.3\left(\mathrm{~d}, \mathrm{~J}_{\mathrm{RhP}} 179 \mathrm{~Hz}\right)$.

${ }^{31} \mathrm{P}\left\{{ }^{1} \mathrm{H}\right\}$ NMR $\left(\mathrm{CD}_{2} \mathrm{Cl}_{2}, 183 \mathrm{~K}, 162 \mathrm{MHz}\right): \delta 97.6$ (d. of d., JRhP $201 \mathrm{~Hz}, J_{\mathrm{PP}} 26 \mathrm{~Hz}$ ), 93.6 (d. of d., JRhP $158 \mathrm{~Hz}, \mathrm{~J}_{\mathrm{PP}} 26 \mathrm{~Hz}$ ) .

ESI-MS: Not stable under mass spectrometric conditions (20eV, 333K). Species with appropriate isotopic distributions at $\mathrm{m} / \mathrm{z}$ found $=581.240$, calculated to $\left[\left(\mathrm{Cy}_{2} \mathrm{PCH}_{2} \mathrm{CH}_{2} \mathrm{PCy}_{2}\right) \mathrm{Rh}\left(\mathrm{N}_{2}\right)_{2}\right]^{+}$(581.242). There is no evidence for the nitrogen compound in bulk samples so it is assumed to form via an in-situ ESI-MS process. 


\section{S.4.2.3. NMR Spectra of $\left[1-C_{4} D_{x}\right.$-alkene][BAr $\left.{ }_{4}\right]$}

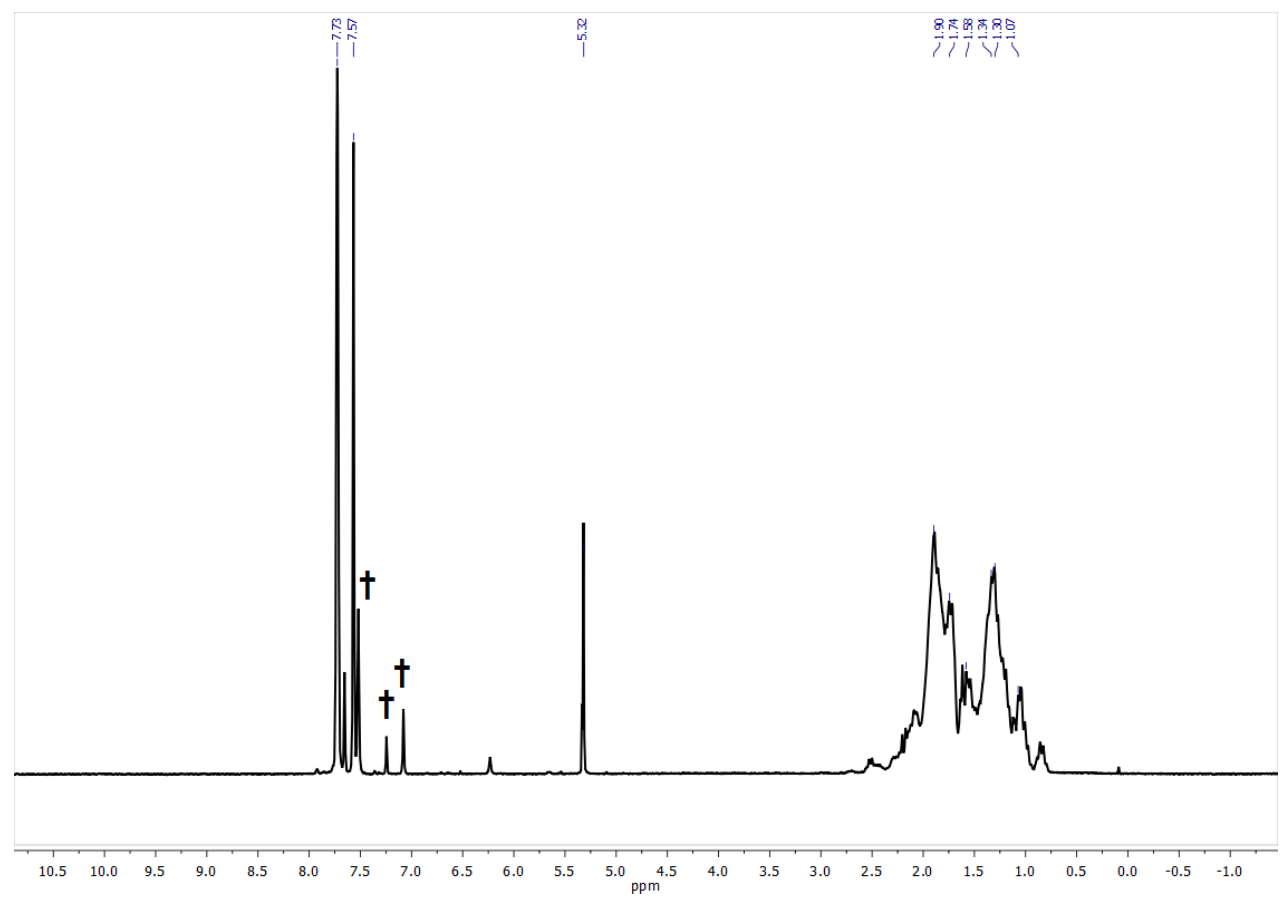

Figure S55: The solution ${ }^{1} \mathrm{H}$ NMR $\left(\mathrm{CD}_{2} \mathrm{Cl}_{2}, 298 \mathrm{~K}, 400 \mathrm{MHz}\right)$ spectrum of $\left[1-\mathrm{C}_{4} \mathbf{D}_{\mathbf{x}^{-}}\right.$ alkene][BAr${ }_{4}$ ]. Signals marked $\dagger$ are due to [1-BAr $\left.{ }_{4}\right]$.

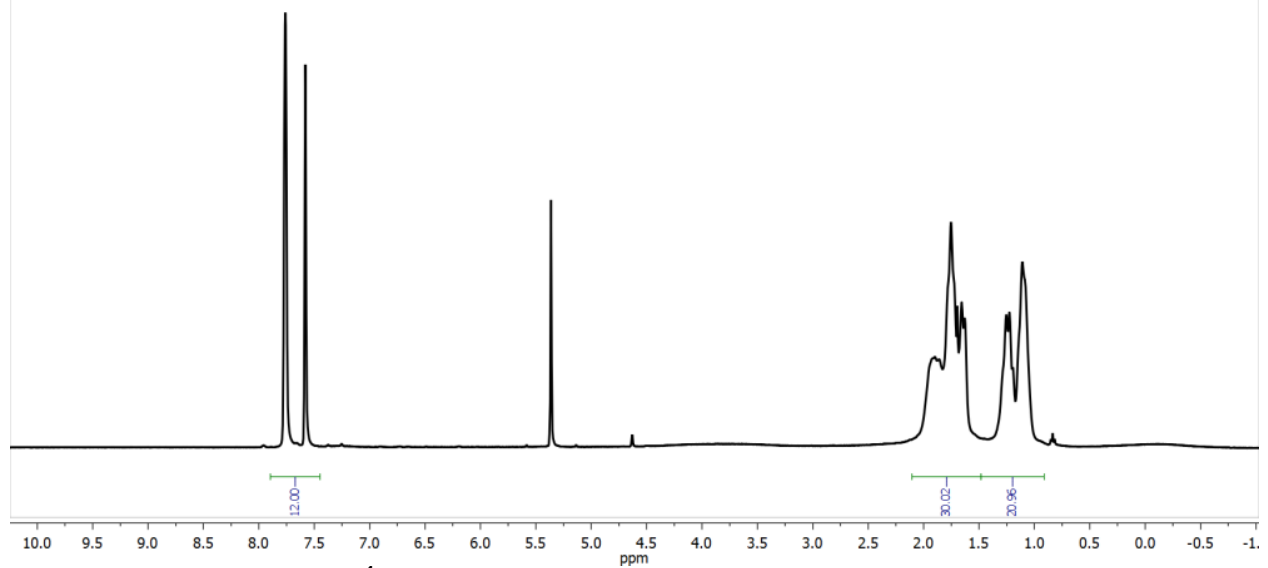

Figure S56: The solution ${ }^{1} \mathrm{H}$ NMR $\left(\mathrm{CD}_{2}{ }^{\mathrm{pom}} \mathrm{C}_{2}, 183 \mathrm{~K}, 400 \mathrm{MHz}\right)$ spectrum of $\left[1-\mathrm{C}_{4} \mathbf{D}_{\mathbf{x}}{ }^{-}\right.$ alkene][BAr${ }_{4}$ ]. Protio-alkene signals are not observed, unlike in Figure S2 of [1$\mathrm{C}_{4} \mathrm{H}_{8}$ ][BAr${ }_{4}$ ] at $183 \mathrm{~K}$, suggestive of isotopic substitution of these protons. 


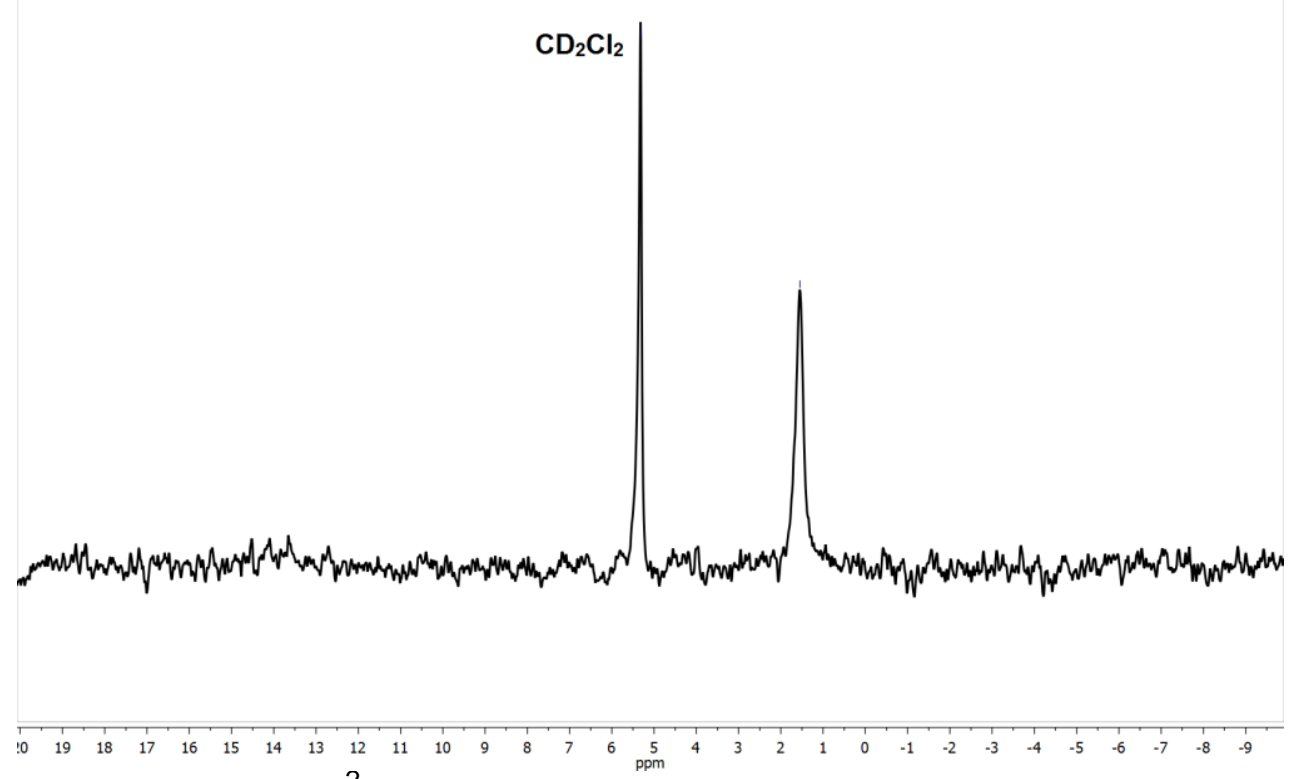

Figure S57: The solution ${ }^{2} \mathrm{H}$ NMR $\left(\mathrm{CH}_{2} \mathrm{Cl}_{2}, 298 \mathrm{~K}, 61 \mathrm{MHz}\right)$ spectrum of $\left[1-\mathrm{C}_{4} \mathrm{D}_{\mathbf{x}^{-}}\right.$ alkene][BAr$\left.{ }_{4}{ }\right]$.

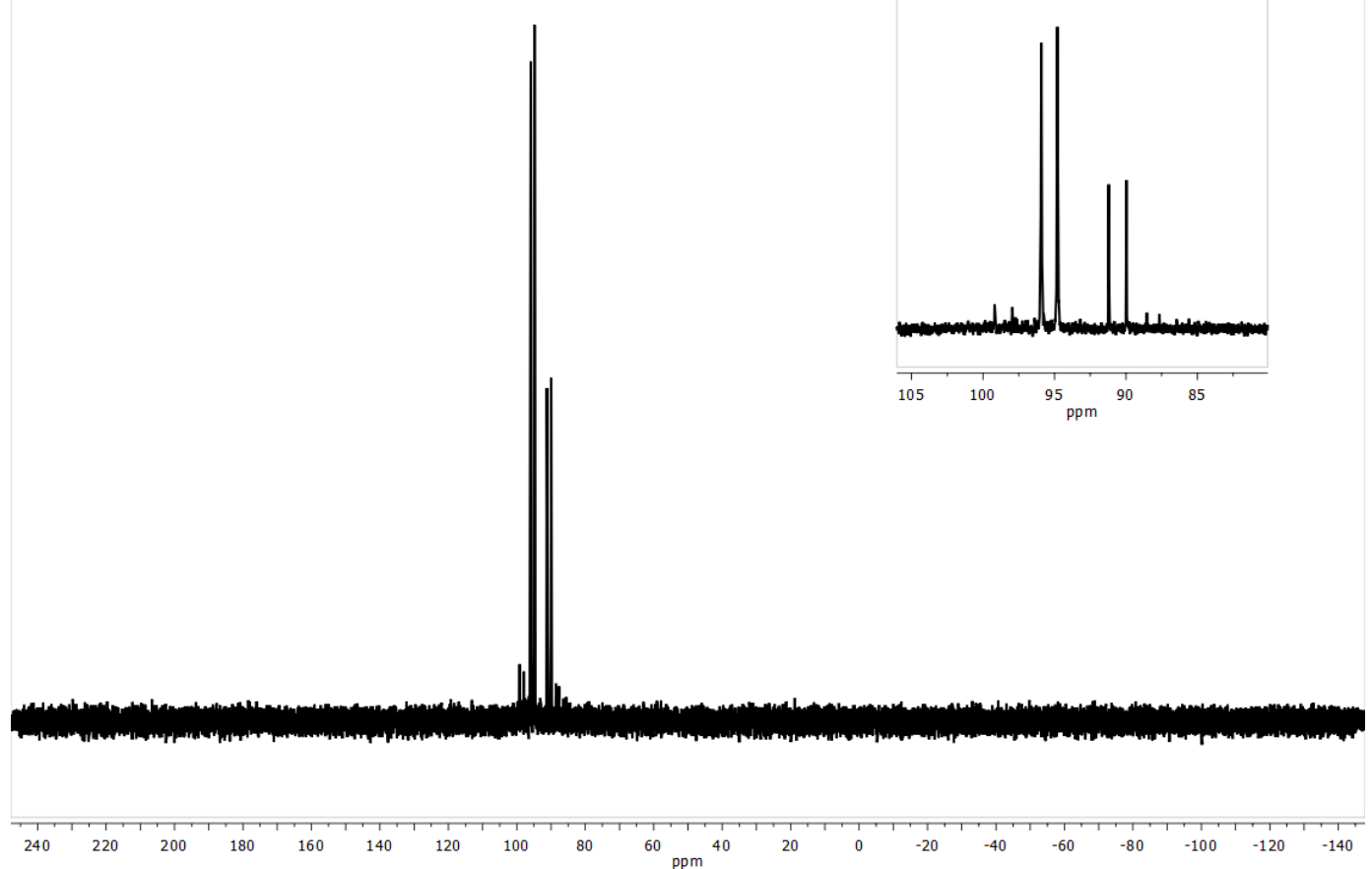

Figure S58: The solution ${ }^{31} \mathrm{P}\left\{{ }^{1} \mathrm{H}\right\} \mathrm{NMR}\left(\mathrm{CD}_{2} \mathrm{Cl}_{2}, 298 \mathrm{~K}, 162 \mathrm{MHz}\right)$ spectrum of [1$\mathbf{C}_{4} \mathbf{D}_{\mathrm{x}}$-alkene][BAr${ }_{4}{ }_{4}$, with $\sim 40 \%$ decomposition to [1-BAr ${ }_{4}$ ]. This decomposition to [1-BAr ${ }_{4}$ ] has occurred after an extended time under $D_{2}$, see section S.2.2.6. 


\section{S.4.2.4. Liberation of bound isobutene- $d_{x}(x=8-6)$}

After preparation of $\left[1-C_{4} D_{x}\right.$-alkene][BAr $\left.{ }_{4}\right]$ following the procedure in section S.4.2.1., [1- $\mathrm{C}_{4} \mathrm{D}_{\mathbf{x}}$-alkene][BAr$\left.{ }_{4}\right]$ was dissolved in $\mathrm{CD}_{2} \mathrm{Cl}_{2}$ in a $\mathrm{J}$ Young NMR tube and the solution was freeze pump thawed degassed three times. CO (1 bar, 298K) was added and after 2 minutes, a vibrant yellow solution had formed of $\left[\mathrm{Rh}(\mathrm{dcpe})(\mathrm{CO})_{2}\right]\left[\mathrm{BAr}{ }_{4}\right]$, confirmed by solution ${ }^{31} \mathrm{P}\left\{{ }^{1} \mathrm{H}\right\}$ NMR spectroscopy ( $\delta$ 85.22, $\left.d, J_{R h P}=116 \mathrm{~Hz}\right),{ }^{S 7}$ as well as liberated isobutene- $d_{x}$. The solvent and volatiles were distilled into a fresh NMR tube and analyzed by ${ }^{1} \mathrm{H},{ }^{2} \mathrm{H},{ }^{13} \mathrm{C}\left\{{ }^{1} \mathrm{H}\right\}$ NMR spectroscopy and GC EI-MS.

\section{S.4.2.5. Characterization data for isobutene- $d_{x}(x=8-6)$}

${ }^{1} \mathrm{H}$ NMR $\left(\mathrm{CD}_{2} \mathrm{Cl}_{2}, 400 \mathrm{MHz}, 298 \mathrm{~K}\right)$ : Residual protio Signals at $\delta 4.69\left(\mathrm{~s}, \mathrm{C}=\mathrm{CH}_{2}\right)$, 1.71 br. m., $\mathrm{CH}_{3}$ )

${ }^{2} \mathrm{H}$ NMR $\left(\mathrm{CD}_{2} \mathrm{Cl}_{2}, 61 \mathrm{MHz}, 298 \mathrm{~K}\right): \delta 4.71$ (br s, 2D, CD), 1.70 (br s, 5.6D, $\mathrm{CD}_{3}$ ).

${ }^{13} \mathrm{C}\left\{{ }^{1} \mathrm{H}\right\} \operatorname{NMR}\left(\mathrm{CD}_{2} \mathrm{Cl}_{2}, 126 \mathrm{MHz}, 298 \mathrm{~K}\right): \delta 142.7\left(\mathrm{~s}, \underline{\mathrm{C}}=\mathrm{CD}_{2}\right.$.), $110.1\left(\mathrm{~m}, \mathrm{C}=\underline{\mathrm{CD}_{2}}\right.$, J $\mathrm{C}-\mathrm{D}$ $=22.8), 23.4\left(\mathrm{~m},-\mathrm{CD}_{3}, \mathrm{~J}_{\mathrm{C}-\mathrm{D}}=20.1\right)$.

ESI-MS found (calc. for $\mathrm{C}_{4} \mathrm{D}_{8}{ }^{+}$): $\mathrm{m} / \mathrm{z} 64.112$ (64.1128).

\section{S.4.2.6. Solution NMR for isobutene- $d_{x}(x=8-6)$}

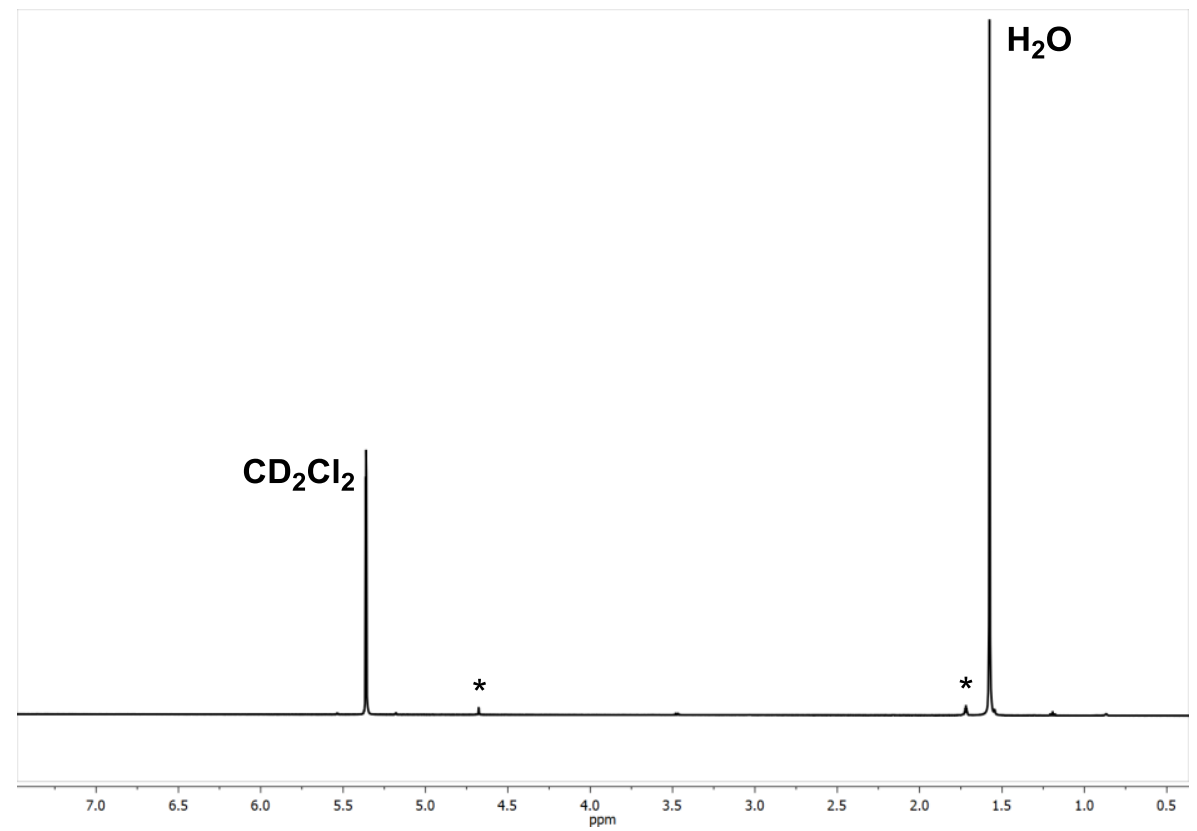

Figure S59: The solution ${ }^{1} \mathrm{H}$ NMR $\left(\mathrm{C}_{6} \mathrm{D}_{6}, 298 \mathrm{~K}, 400 \mathrm{MHz}\right)$ spectrum of isolated volatiles of isobutene- $d_{x}$. The signals marked * are from residual protio-isobutene. 


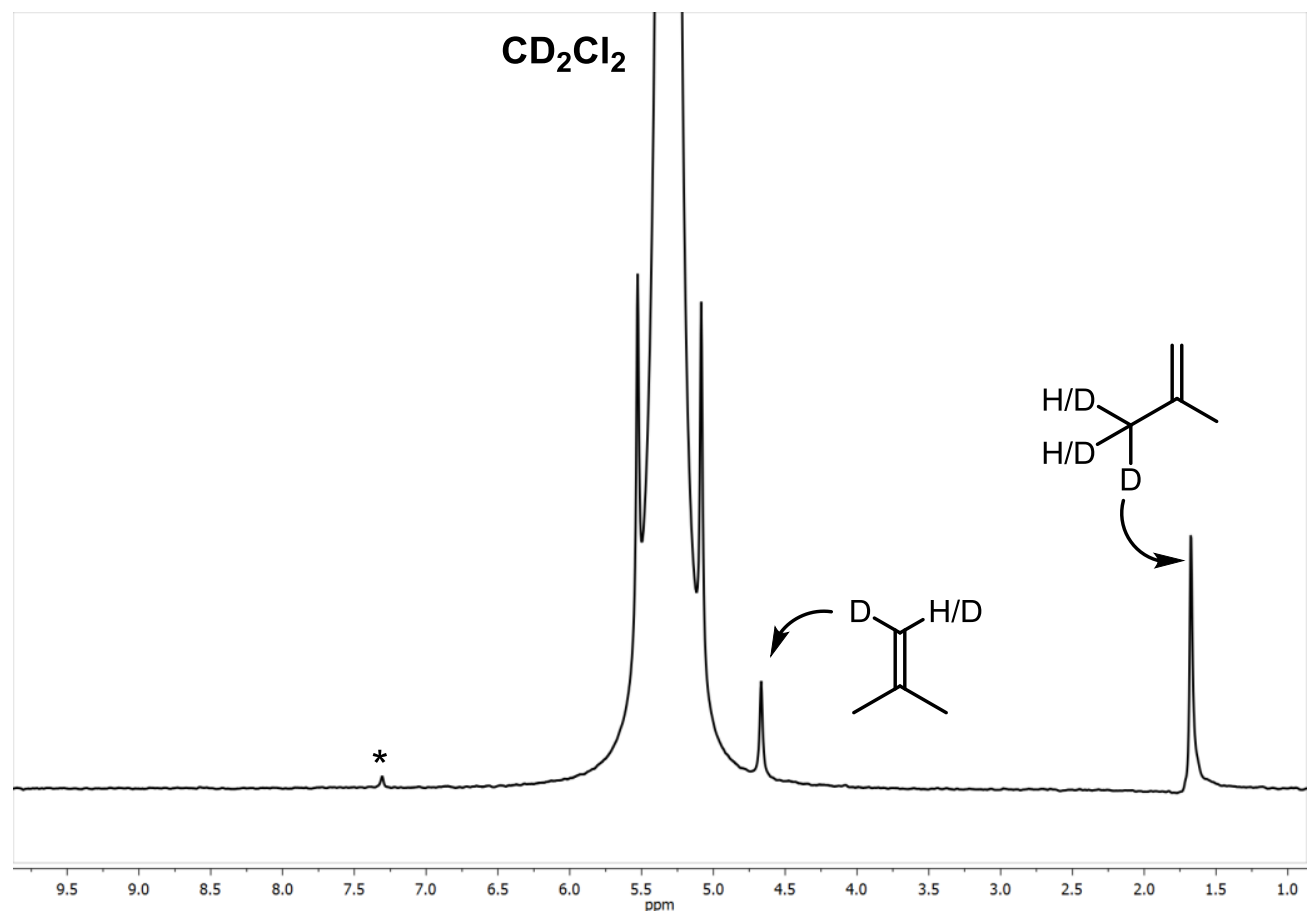

Figure S60: The solution ${ }^{2} \mathrm{H}$ NMR $\left(\mathrm{CD}_{2} \mathrm{Cl}_{2}, 298 \mathrm{~K}, 61 \mathrm{MHz}\right)$ spectrum of isolated volatiles of isobutene- $d_{x}$. The signals marked ${ }^{*}$ are from a $\mathrm{CDCl}_{3}$ impurity.

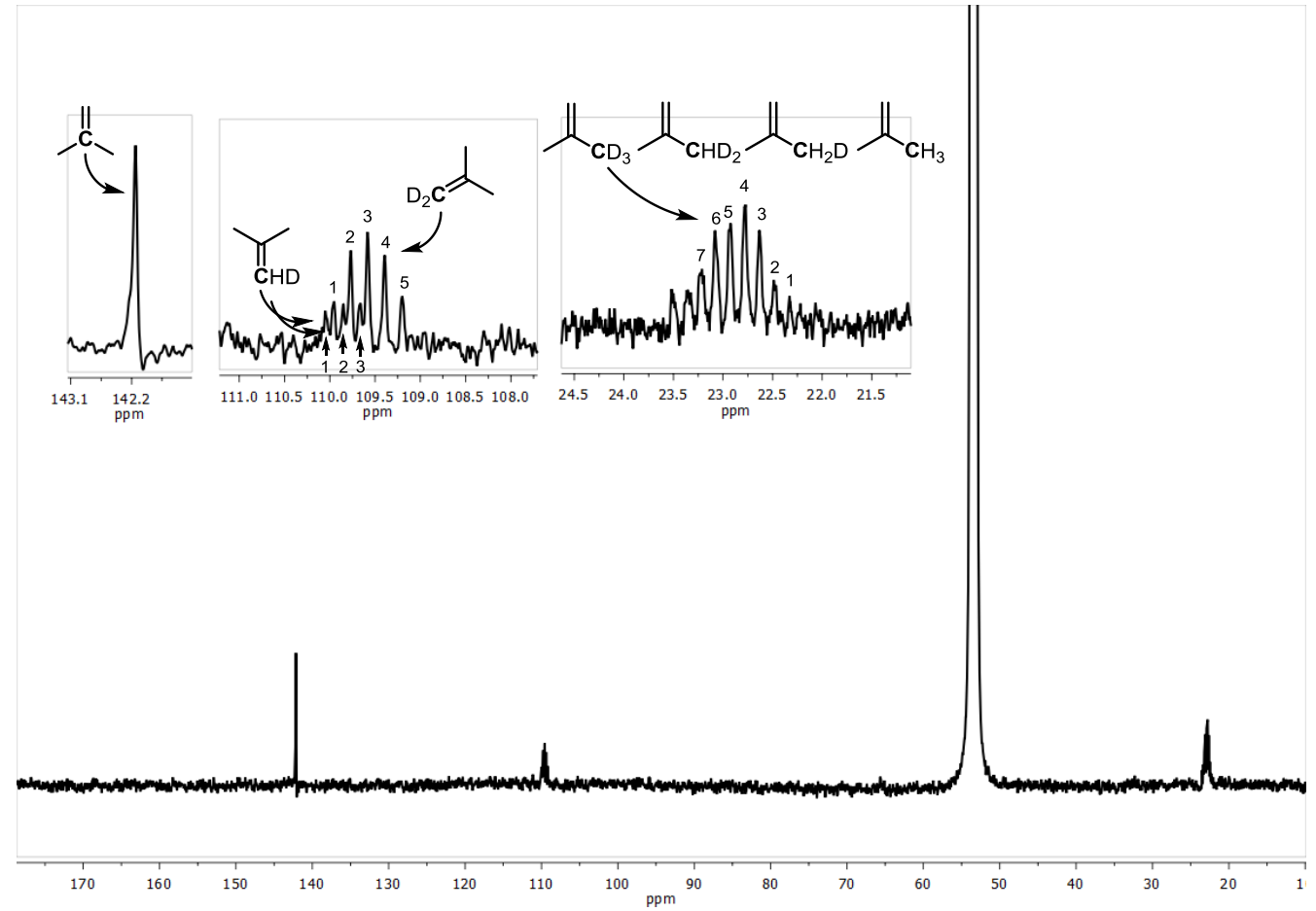

Figure S61: The solution ${ }^{13} \mathrm{C}\left\{{ }^{1} \mathrm{H}\right\} \mathrm{NMR}\left(\mathrm{CD}_{2} \mathrm{Cl}_{2}, 298 \mathrm{~K}, 126 \mathrm{MHz}\right)$ spectrum of isolated volatiles of isobutene- $d_{x}$. 


\section{S.4.2.7. GC EI-MS Mass Spectra of isobutene- $d_{x}(x=8-6)$}

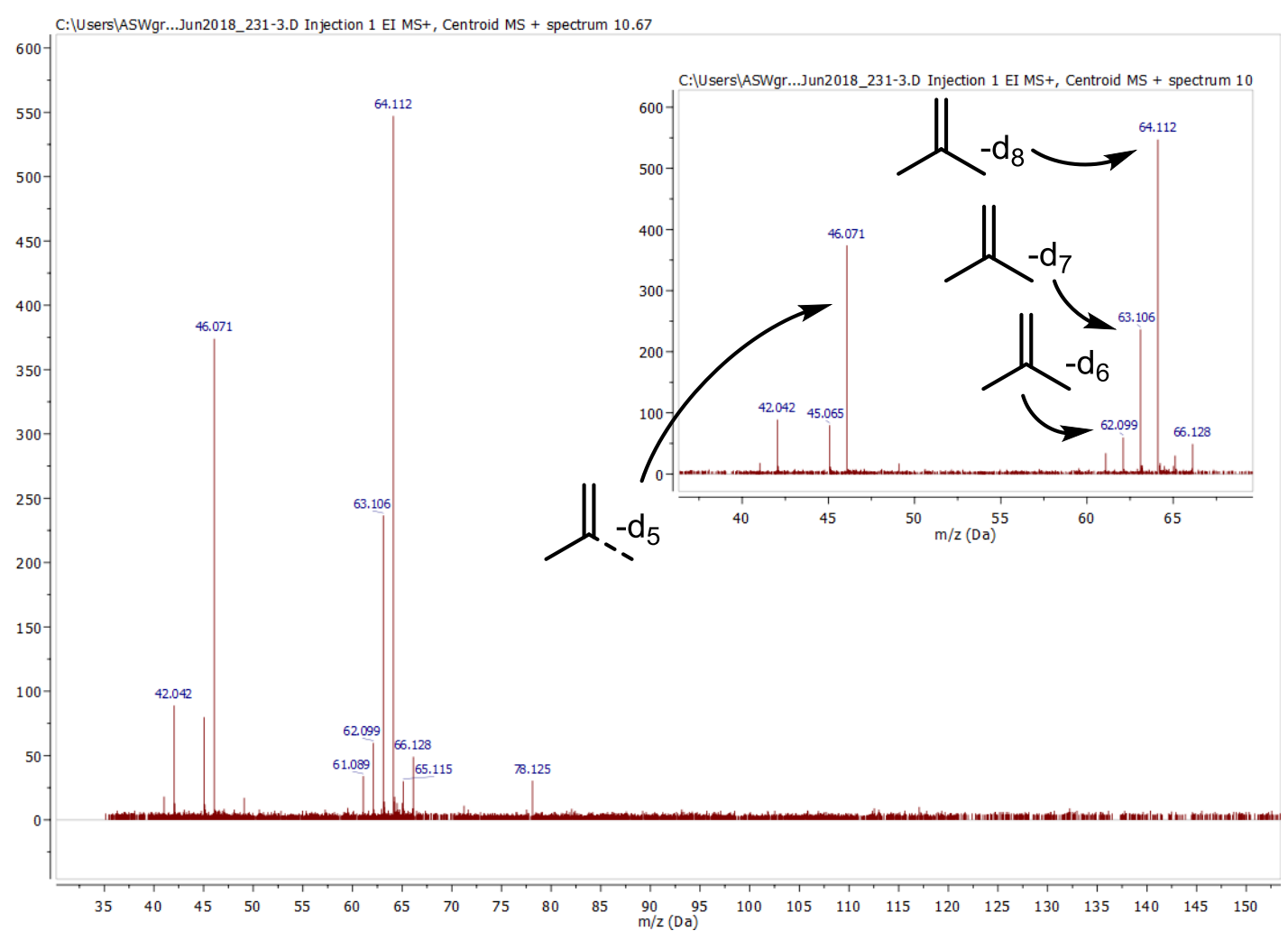

Figure S62: Mass spectrum of the isolated isobutene- $d_{x}$ with enlargement of $\mathrm{m} / \mathrm{z}=$ $35-70$ region. The molecular ion peak is that of $\mathrm{C}_{4} \mathrm{D}_{8}{ }^{+}, \mathrm{m} / \mathrm{z}=64.112$ (calc. 64.1128) with greatest intensity fragment of $\mathrm{C}_{3} \mathrm{D}_{5}{ }^{+}, \mathrm{m} / \mathrm{z}=46.071$ (calc. $=46.0705$ ). The 3 major isotopic contributions are that of $\mathrm{C}_{4} \mathrm{D}_{8}{ }^{+}, \mathrm{C}_{4} \mathrm{HD}_{7}{ }^{+}$and $\mathrm{C}_{4} \mathrm{H}_{2} \mathrm{D}_{6}{ }^{+}$, as shown by signals at $64.112,63.106$ and 62.099 respectively. 


\section{S.4.2.8. Simulated solution ${ }^{13} C\left\{{ }^{1} H\right\}$ NMR spectra of isobutene- $d_{x}(x=8-6)$}

As per section S.3.1.4., the solution ${ }^{13} C\left\{{ }^{1} H\right\}$ NMR of isolated isobutene- $d_{x}(x=8-6)$ (Figure S61) was de-convoluted using the Spin Simulation function on MestReNova, shown in Figure S63. Line width was kept at $4.5 \mathrm{~Hz}$ throughout, only changing levels of population in each simulated environment.

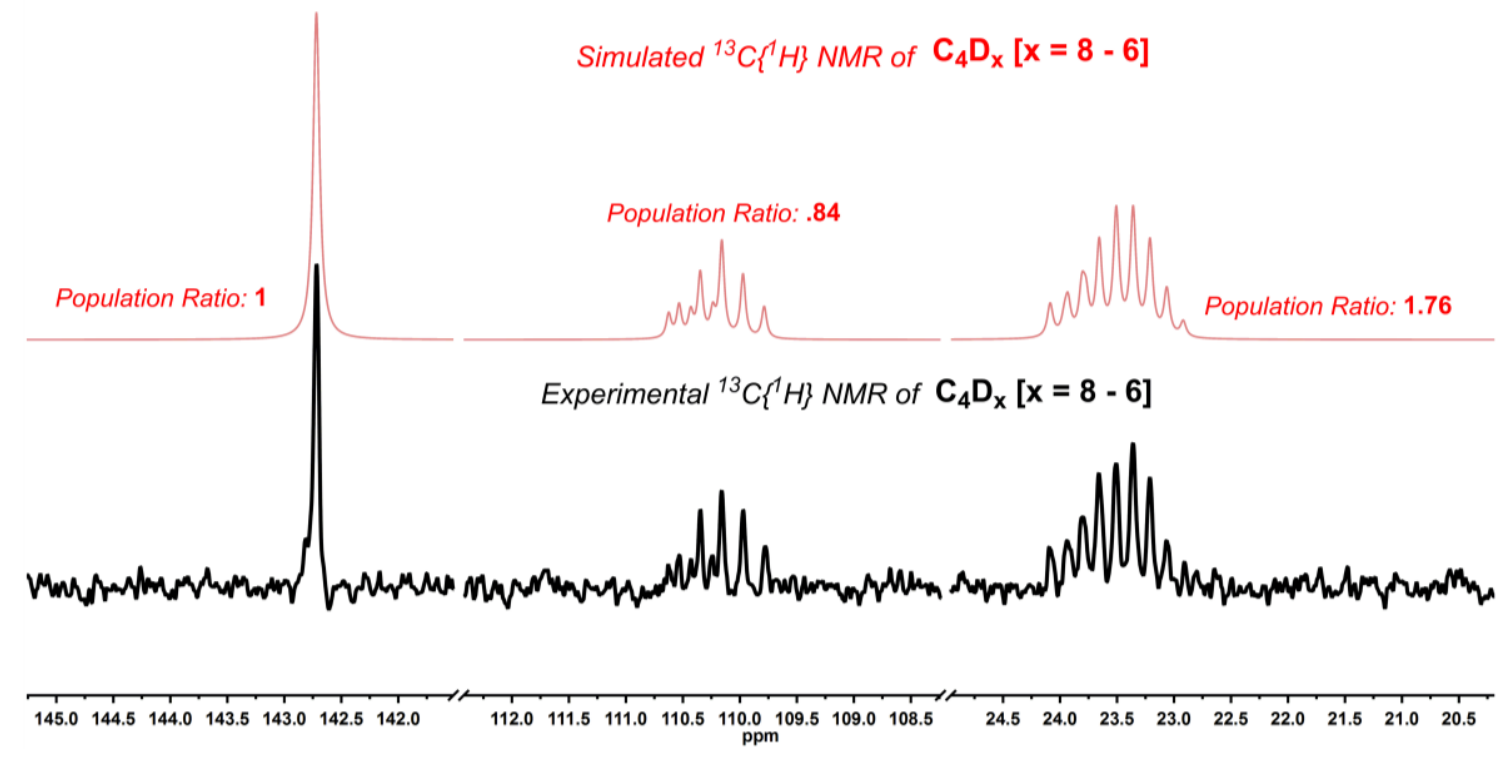

Figure S63: Simulated and partial experimental solution ${ }^{13} \mathrm{C}\left\{{ }^{1} \mathrm{H}\right\}$ NMR spectra of isobutene- $d_{x}(x=8-6)$. The three separate ${ }^{13} \mathrm{C}$-environments are assigned to methyl ${ }^{13} \mathrm{C}(\delta \sim 23)$, methylene ${ }^{13} \mathrm{C}(\delta \sim 110)$ and quaternary ${ }^{13} \mathrm{C}(\delta \sim 142)$.

The population ratio of each ${ }^{13} \mathrm{C}$ environment in the simulated spectra was calculated from the sum of each individual $-\mathrm{CD}_{X} \mathrm{H}_{Y}$ component in each environment compared between environments. These ratios suggest an approximate 1:1:2 ratios of carbon environments, in line with that of isobutene. 


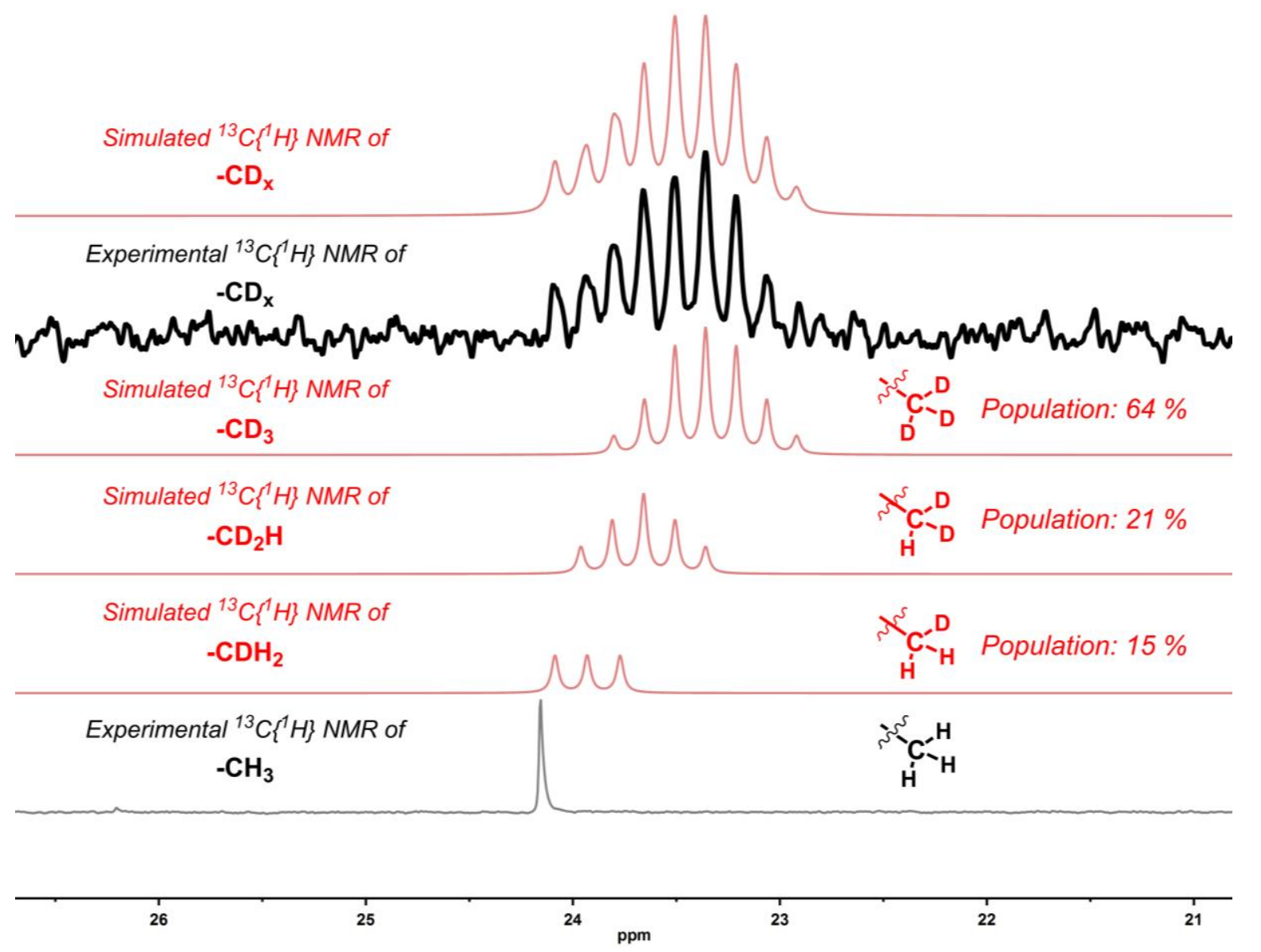

Figure S64: Three systems were used to recreate the multiplet at $\delta 23.5$ from the methyl environment, modelling $-\mathrm{CD}_{3},-\mathrm{CD}_{2} \mathrm{H}$ and $-\mathrm{CDH}_{2}$ groups. No evidence of $\mathrm{CH}_{3}$ could be seen in the experimental data so was not modelled. The simulation from this environments suggests that $64 \%$ of $-\mathrm{CX}_{3}$ groups are were of $-\mathrm{CD}_{3}$ in nature, $21 \%-\mathrm{CD}_{2} \mathrm{H}$ and $15 \%-\mathrm{CDH}_{2}$. 


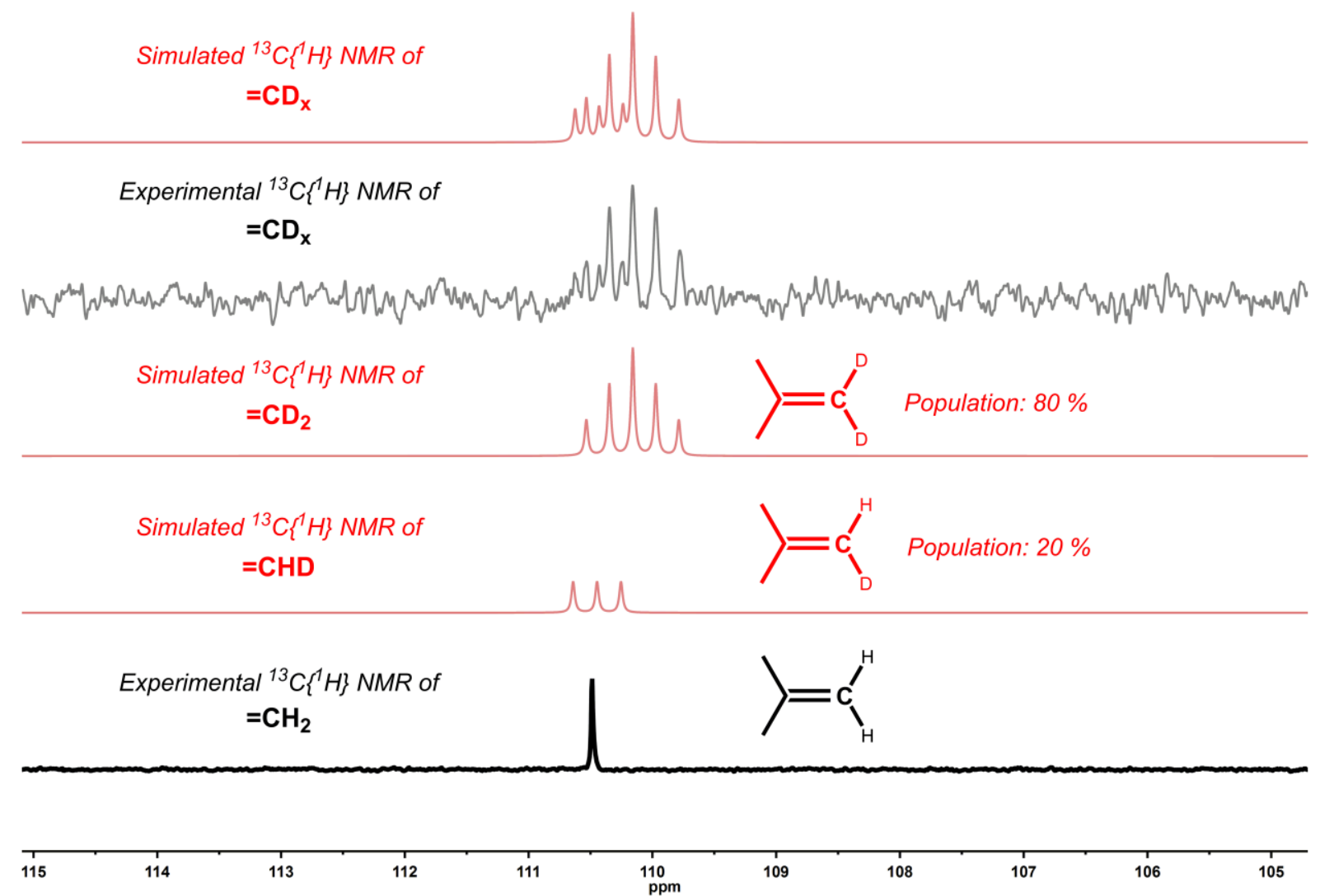

Figure S65: Two systems were used to recreate the multiplet at $\delta 110$ from the methylene environment, modelling $=\mathrm{CD}_{2}$ and $=\mathrm{CDH}$ groups. No evidence of $=\mathrm{CH}_{2}$ could be seen in the experimental data so was not modelled. The simulation from these environments suggests that $80 \%$ of $=C D_{x}$ groups are $=C_{2}$, and $20 \%=-$ $\mathrm{CDH}$. 


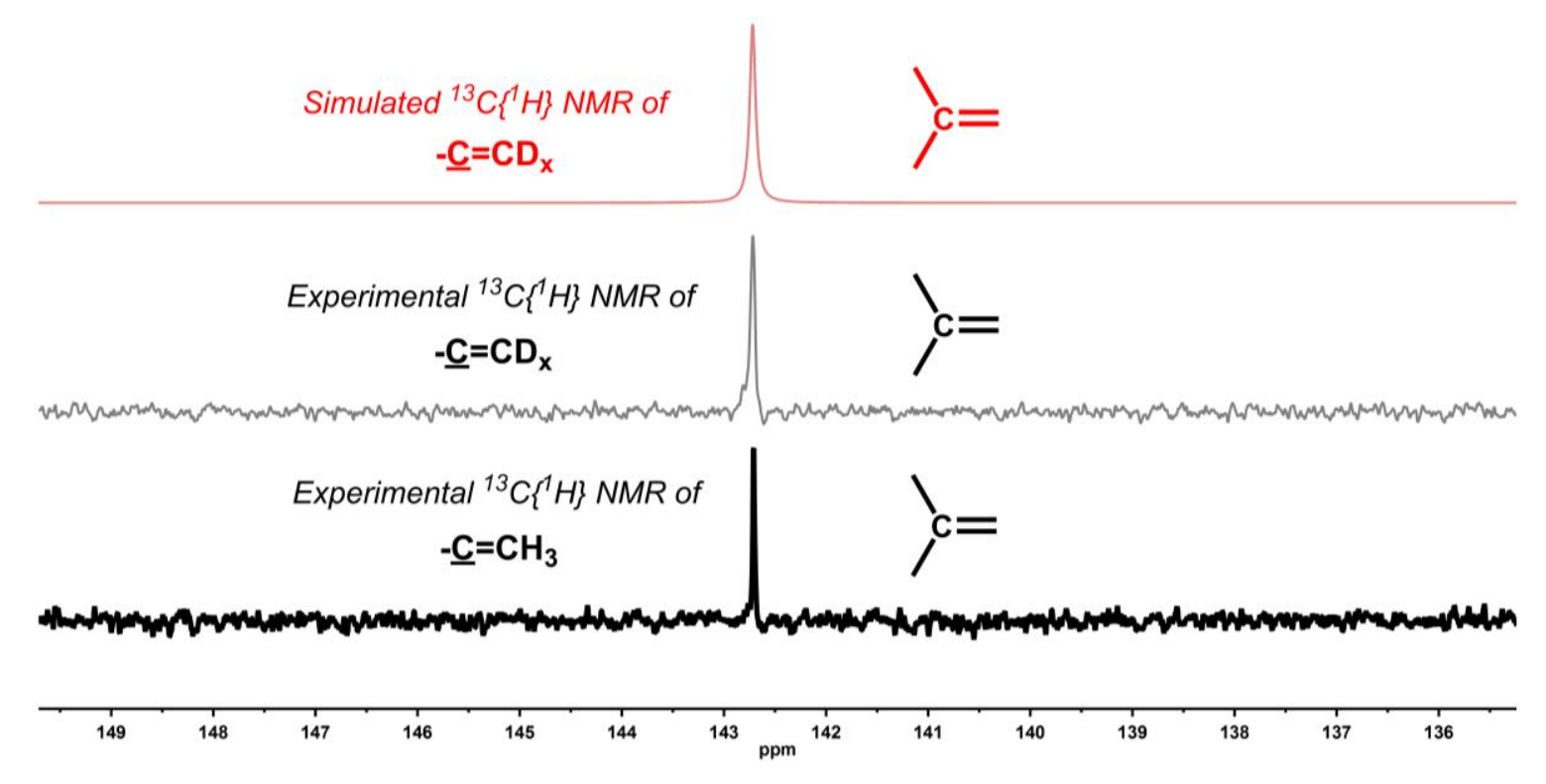

Figure S66: The singlet from the quaternary carbon at $\delta 142$ was also modeled. This simulation was used as an approximate internal standard. The slight variation in chemical shift between the deuterated and proto isobutene $(\delta \sim .05)$ we have assign to secondary isotope effects.

Overall, the three figures (S64 - S66) describe the full calculated breakdown of deuterated isobutene, confirming a high level of deuteration incorporation. This is consistent with the GC EI-MS shown in Figure S62, which showed a high amount of deuterated isobutene $\left(\mathrm{C}_{4} \mathrm{D}_{8}^{+}\right.$to $\left.\mathrm{C}_{4} \mathrm{D}_{6}{ }^{+}\right)$.

However, overall, lower levels of deuteration are observed compared to isobutane- $d_{x}$

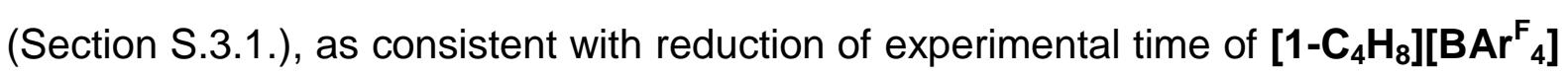
under an $D_{2}$ atmosphere (30 vs 90 mins), see sections S.3.1. and S.4.2. 


\section{S.4.3. Solid-state dehydrogenation of $\left[1-\mathrm{C}_{6} \mathrm{H}_{12}\right]\left[B A \mathrm{Br}_{4}\right]$ to form $\left[1-\mathrm{C}_{6} \mathrm{H}_{8}\right]\left[\mathrm{BAr}{ }_{4}{ }_{4}\right]$}

S.4.3.1. Solid-state dehydrogenation of $\left[1-\mathrm{C}_{6} \mathrm{H}_{12}\right]\left[\mathrm{BAr}{ }_{4}\right]$ under argon flow to form $\left[1-\mathrm{C}_{6} \mathrm{H}_{8}\right]\left[B \mathrm{Brr}_{4}\right]$
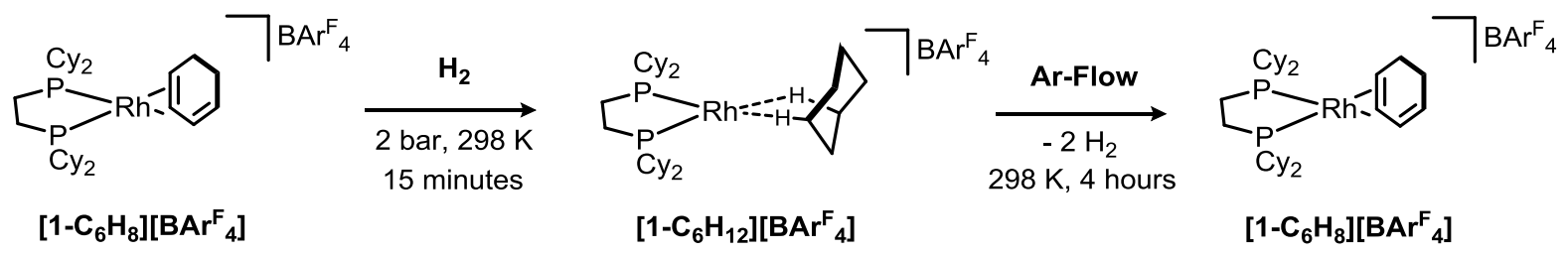

A powdered microcrystalline sample of [1- $\left.\mathbf{C}_{6} \mathrm{H}_{8}\right]\left[\mathrm{BAr}_{4}{ }_{4}\right]$ (35 mg) was packed in a 3.2 mm SSNMR rotor, inside an argon filled glove box. The rotor was then placed in a custom built glass $\mathrm{J}$ Young flask ${ }^{\mathrm{S7}}$ and the sample was then exposed to $\mathrm{H}_{2}$ (1 bar, $298 \mathrm{~K}$ ) for 20 minutes, to yield deep red crystalline powder of [1- $\left.{ }_{6} \mathbf{H}_{12}\right]\left[B \mathbf{B r}_{4}\right]$.

The sample was then placed under an argon flow for 18 hours. This was done by placing an exit needle into the suba sealed $J$ Young flask which was open to argon flow, with regulator pressure set at 0.5 bar. After 18 hours, the rotor cap was fitted under a flush of $\mathrm{Ar}$, and immediately transferred to the bore of a SSNMR spectrometer and analyzed ${ }^{31} \mathrm{P}\left\{{ }^{1} \mathrm{H}\right\}$ and ${ }^{13} \mathrm{C}\left\{{ }^{1} \mathrm{H}\right\}$ solid state NMR spectroscopy. 


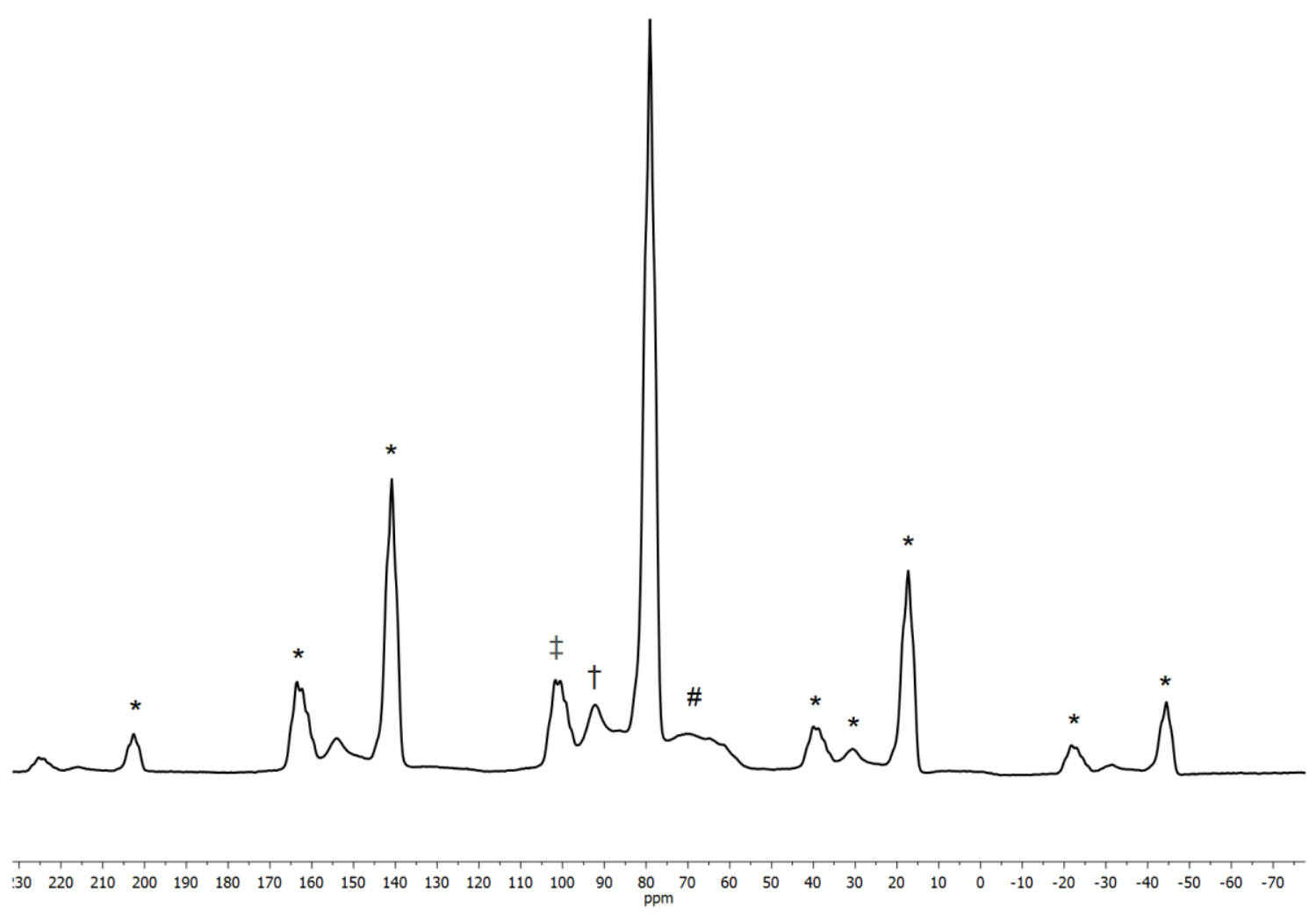

Figure S67: The ${ }^{31} \mathrm{P}\left\{{ }^{1} \mathrm{H}\right\}$ SSNMR (162 MHz, $295 \mathrm{~K}, 10 \mathrm{kHz}$ spin rate) spectrum of the dehydrogenation of powdered microcrystalline $\left[1-\mathrm{C}_{6} \mathrm{H}_{12}\right]\left[\mathrm{BAr}_{4}\right]$ under an argon flow. The resonance at $\delta 78$ corresponds to $\left[1-\mathrm{C}_{6} \mathrm{H}_{8}\right]\left[\mathrm{BAr}{ }_{4}\right]$, in comparison to clean [1- $\left.\mathrm{C}_{6} \mathrm{H}_{8}\right]\left[\mathrm{BAr}_{4}{ }_{4}\right]$ shown in Figure S21. The resonances $\ddagger$ marked are assigned to [1$\mathrm{C}_{6} \mathrm{H}_{10}$ ] $\left[\mathrm{BAr} \mathrm{F}_{4}\right.$ ], from incomplete dehydrogenation and + from [1-BAr${ }_{4}{ }_{4}$, formed from a side reaction when under $\mathrm{H}_{2}$ atmosphere. The resonances marked \# are assigned to as yet unidentified decomposition products. The resonances marked ${ }^{*}$ are due to spinning sidebands. 


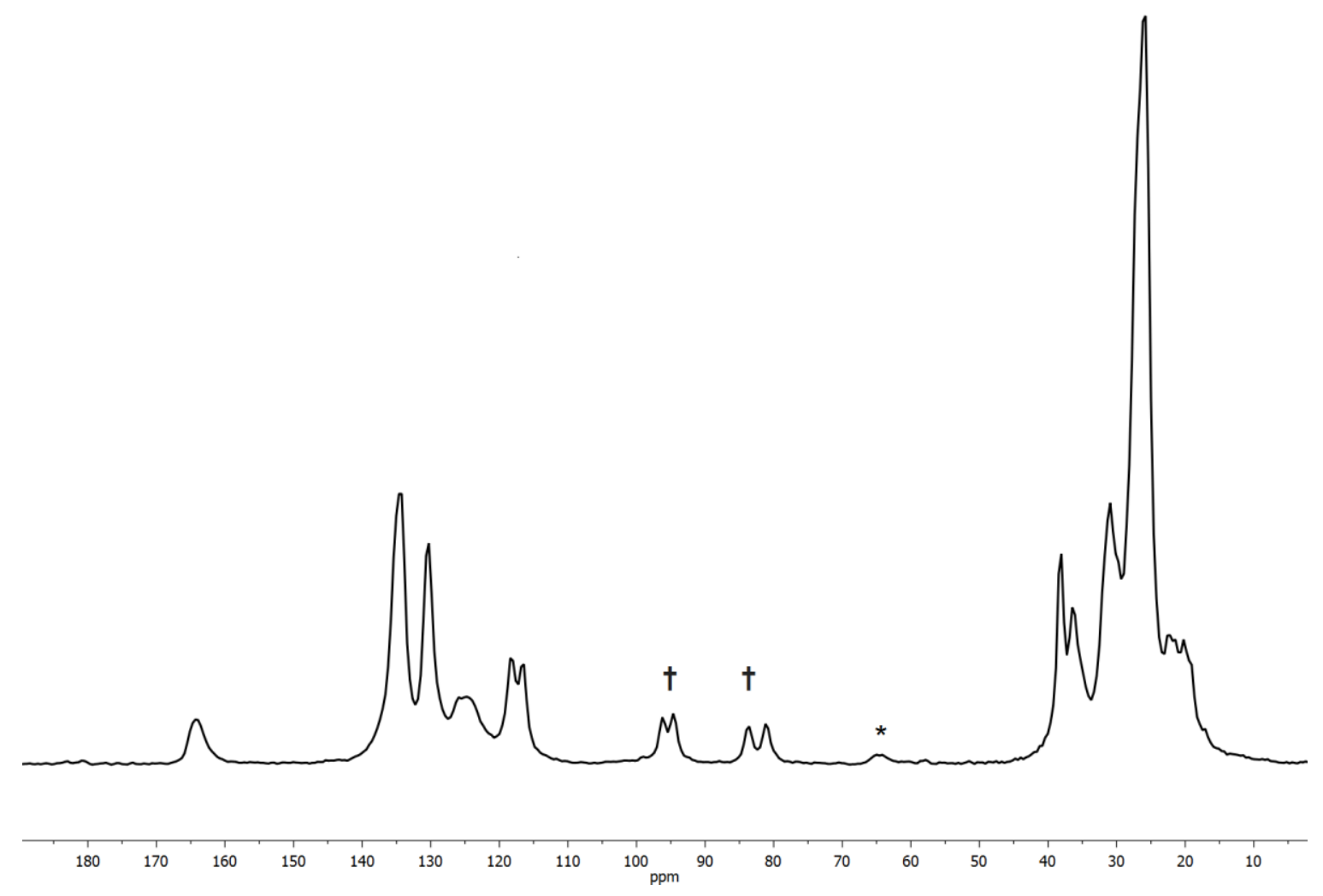

Figure S68: The ${ }^{13} \mathrm{C}\left\{{ }^{1} \mathrm{H}\right\}$ SSNMR (100 MHz, $295 \mathrm{~K}, 10 \mathrm{kHz}$ spin rate) spectrum of the dehydrogenation of powdered microcrystalline $\left[1-\mathbf{C}_{6} \mathrm{H}_{12}\right]\left[\mathrm{BAr}_{4}\right]$ under an argon flow. The resonances marked † correspond to the alkene signals in $\left[1-\mathrm{C}_{6} \mathrm{H}_{8}\right]\left[\mathrm{BAr}{ }_{4}\right]$, in comparison to clean $\left[1-\mathrm{C}_{6} \mathrm{H}_{8}\right]\left[\mathrm{BAr}_{4}{ }_{4}\right]$ shown in Figure S22. The resonances marked * are due to spinning sidebands. 


\section{S.4.3.2. Solid-state dehydrogenation of $\left[1-\mathrm{C}_{6} \mathrm{H}_{12}\right]\left[\mathrm{BAr}_{4}{ }_{4}\right]$ under vacuum to form $\left[1-\mathrm{C}_{6} \mathrm{H}_{8}\right]\left[B \mathrm{Brr}_{4}{ }_{4}\right]$}

A $J$ Young NMR tube was charged with powdered microcrystalline [1- $\left.\mathbf{C}_{6} \mathbf{H}_{8}\right]\left[B \mathbf{B r}^{\mathrm{F}_{4}}\right.$ ] (10 mgs) in an argon filled glove box. The sample was then evacuated $\left(2 \times 10^{-2}\right.$ mbar) and backfilled with $\mathrm{H}_{2}(1 \mathrm{bar}, 298 \mathrm{~K})$ for 15 minutes. The sample was then cooled to $77 \mathrm{~K}$ in liquid nitrogen and evacuated. After a steady vacuum was achieved $\left(2 \times 10^{-2} \mathrm{mbar}\right)$ the sample was rapidly warmed to $298 \mathrm{~K}$ and a timer was simultaneously started. After a set period of time (5 mins to 960 mins), the sample was cooled to $77 \mathrm{~K}$ in liquid nitrogen and $\mathrm{CH}_{2} \mathrm{Cl}_{2}(0.40 \mathrm{~mL})$ was condensed into the NMR tube. The sample was expediently thawed and rapidly transferred to the bore of a precooled (183 K) NMR spectrometer which was previously locked and shimmed to a sample of $\mathrm{CD}_{2} \mathrm{Cl}_{2} . \mathrm{A}^{31} \mathrm{P}\left\{{ }^{1} \mathrm{H}\right\}$ NMR spectrum was then acquired.

The above procedure was repeated on numerous occasions, varying the period of time the sample was exposed to vacuum at room temperature.

Note: Vacuum pressure was used to normalize the conditions, opposed to an argon flow as per section S.4.3.1.

Three species are identified in the ${ }^{31} \mathrm{P}\left\{{ }^{1} \mathrm{H}\right\}$ solution NMR spectra;

[1-( $\left.\left.\mathrm{CH}_{2} \mathrm{Cl}_{2}\right)_{\text {n] }}\right]\left[\mathrm{BAr}_{4}\right.$ ] $: \delta 97.2\left(\mathrm{br} \mathrm{d}, \mathrm{J}_{\mathrm{RhP}} 203 \mathrm{~Hz}\right)$.

[1- C $_{6} \mathrm{H}_{10}$ ][BAr ${ }_{4}$ ]: $\delta 96.9$ (dd, J JhP $207 \mathrm{~Hz}, \mathrm{~J}_{P P} 24 \mathrm{~Hz}$ ), 90.4 (dd, J JhP $159 \mathrm{~Hz}, J_{P P} 24$ $\mathrm{Hz})$.

$\left[1-\mathrm{C}_{6} \mathrm{H}_{8}\right]\left[\mathrm{BAr}_{4}{ }_{4}\right]: \delta 78.3\left(\mathrm{~d}, \mathrm{~J}_{\mathrm{RhP}} 172 \mathrm{~Hz}\right)$.

Note: A powdered crystalline sample of $\left[1-\mathrm{C}_{6} \mathrm{H}_{8}\right]\left[\mathrm{BAr}_{4}\right]$ was placed under vacuum $\left(1 \times 10^{-2}\right.$ mbar) for a period of 2 weeks. ${ }^{1} \mathrm{H}$ and ${ }^{31} \mathrm{P}\left\{{ }^{1} \mathrm{H}\right\}$ NMR spectra of the dissolved solid $\left(\mathrm{CD}_{2} \mathrm{Cl}_{2}\right)$ showed no significant change, and no $\left[1-\mathrm{C}_{6} \mathrm{H}_{6}\right]\left[\mathrm{BAr}{ }_{4}\right]$ was observed. 
A

$960 \mathrm{~min}$

$240 \mathrm{~min}$

لالمالم

Ull

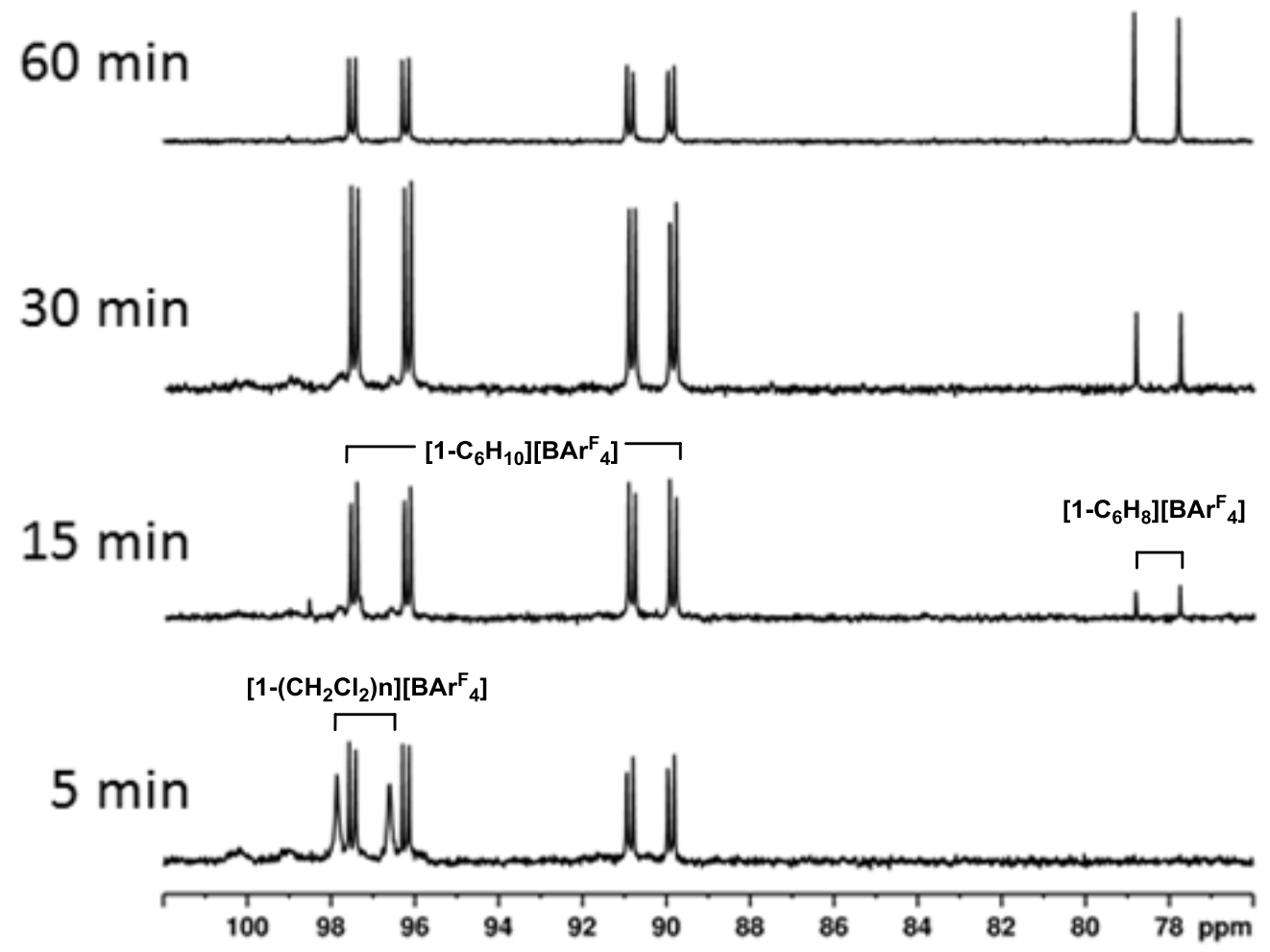

B

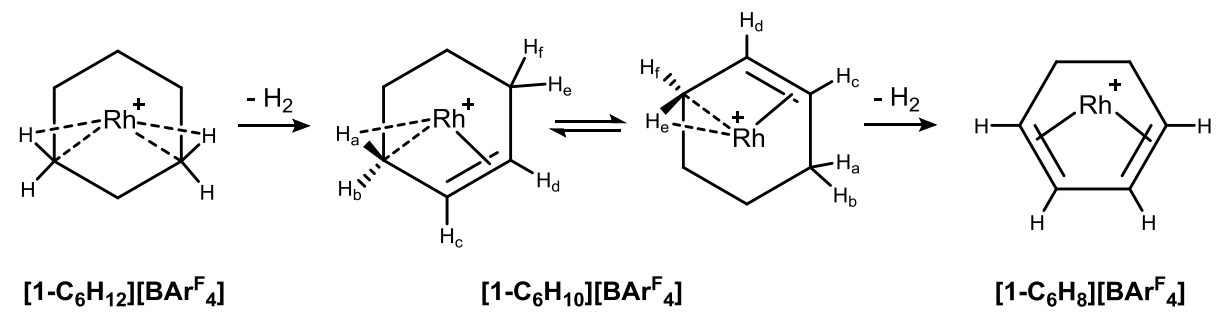

Figure S69: (A) Representative solution ${ }^{31} \mathrm{P}\left\{{ }^{1} \mathrm{H}\right\} \mathrm{NMR}\left(\mathrm{CH}_{2} \mathrm{Cl}_{2}, 183 \mathrm{~K}, 162 \mathrm{MHz}\right)$ spectra of [1- $\left.\mathrm{C}_{6} \mathrm{H}_{12}\right]\left[\mathrm{BAr}{ }_{4}\right]$ exposed to vacuum for various periods of time in the solid-state then quenched by condensing $\mathrm{CH}_{2} \mathrm{Cl}_{2}$ onto the sample. (B) Structural diagrams of the species present during the dehydrogenation reactions; phosphine units and $\left[\mathrm{BAr}_{4}\right]^{-}$anions removed for clarity. 


\section{S.4.3.3. Kinetics of the solid-state $\left[1-\mathrm{C}_{6} \mathrm{H}_{12}\right]\left[B \mathrm{Br}_{4}^{\mathrm{F}}\right]$ dehydrogenation under vacuum to form $\left[1-\mathrm{C}_{6} \mathrm{H}_{8}\right]\left[B \mathrm{Br}_{4}{ }_{4}\right]$}

In contrast to the dehydrogenation of [1- $\left.\mathrm{C}_{4} \mathrm{H}_{10}\right]\left[\mathrm{BAr}_{4}{ }_{4}\right]$, the dehydrogenation of [1$\mathrm{C}_{6} \mathrm{H}_{12}$ ][BAr $\mathrm{F}_{4}$ ] proceeds in two stages. Given the poor stability of the intermediate complex of [1- $\left.\mathbf{C}_{6} \mathbf{H}_{10}\right]\left[B \mathbf{B r}_{4}{ }_{4}\right]$ in solution, the ${ }^{31} \mathrm{P}\left\{{ }^{1} \mathrm{H}\right\}$ NMR spectra used in the kinetic

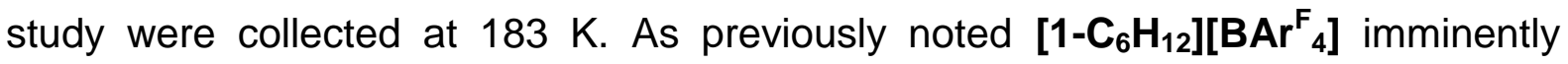
reacts with $\mathrm{CH}_{2} \mathrm{Cl}_{2}$ even at low temperatures to form several species two of which we have tentatively assigned as $\left[1-\left(\mathrm{CH}_{2} \mathrm{Cl}_{2}\right)_{n}\right]\left[\mathrm{BAr}{ }_{4}\right]$ and [1-BAr$\left.{ }_{4}\right]$. At $183 \mathrm{~K}$, the resonances of these species are typically very broad.

Dehydrogenation reactions were undertaken in $J$ Young NMR tubes containing capillaries of a ${ }^{31} \mathrm{P}$ NMR standard $\left(\mathrm{PPh}_{3}\right.$ in $\mathrm{d}_{6}$-acetone), in which a known amount of powdered crystalline $\left[1-\mathrm{C}_{6} \mathrm{H}_{8}\right]\left[\mathrm{BAr}{ }_{4}\right]$ was hydrogenated, then subjected to vacuum for a range of times from 15 mins to 960 mins, and worked up as per the procedure outlined in section S.4.3.3. The concentration of each capillary was calibrated to a sample of $\mathrm{Cy}_{2} \mathrm{PCH}_{2} \mathrm{CH}_{2} \mathrm{PCy}_{2}$ in $\mathrm{CH}_{2} \mathrm{Cl}_{2}$ at $183 \mathrm{~K}$. The concentrations of the species involved were referenced against the internal standard. 


\section{$\left[1-\mathrm{C}_{6} \mathrm{H}_{12}\right]\left[B \mathrm{BrF}_{4}\right]$ Dehydrogenation}

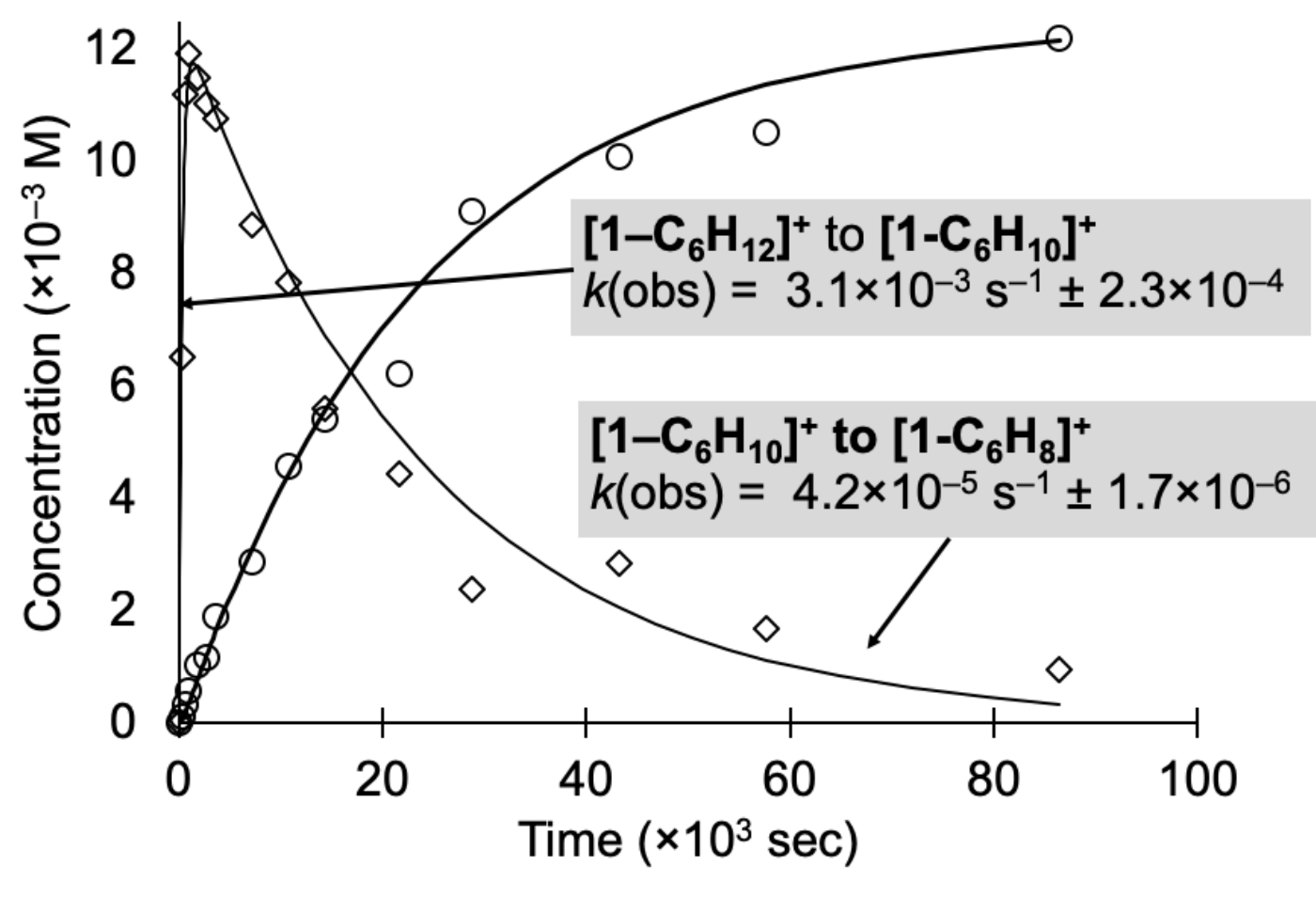

Figure S70: Temporal evolution of dehydrogenation of $\left[1-\mathrm{C}_{6} \mathrm{H}_{12}\right]\left[\mathrm{BAr} \mathrm{F}_{4}\right]$ under vacuum ( $\left.1 \times 10^{-2} \mathrm{mbar}\right)$. Each data point comes from a separate experiment using $10 \mathrm{mg}$ crystalline material, subjected to a vacuum for a set period of time and dissolved in cold $\mathrm{CD}_{2} \mathrm{Cl}_{2}(0.4 \mathrm{~mL})$ that has been vacuum transferred into the sample.

This gives a $[\mathrm{Rh}]_{\text {TOT }}=13 \times 10^{-3} \mathrm{M}$. Integrals measured using quantitative ${ }^{31} \mathrm{P}\left\{{ }^{1} \mathrm{H}\right\}$ NMR spectroscopy at $183 \mathrm{~K}$ of the resulting Rh-complexes, [1-BAr${ }_{4}$ ] (a proxy for

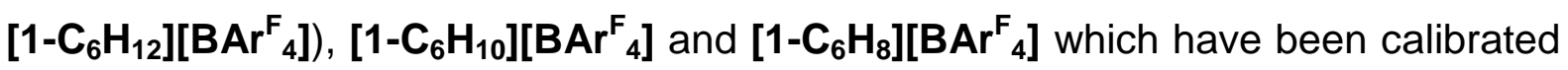
from use of an internal standard of $\mathrm{PPh}_{3}$ in a sealed capillary.

Solid-lines are fits for COPASI ${ }^{\mathrm{S10}}$ modelled processes for the sequential dehydrogenation ([1- $\left.\left.\mathrm{C}_{6} \mathrm{H}_{12}\right]\left[B A \mathrm{Br}_{4}\right] \rightarrow\left[1-\mathrm{C}_{6} \mathrm{H}_{10}\right]\left[\mathrm{BAr}{ }_{4}\right] \rightarrow\left[1-\mathrm{C}_{6} \mathrm{H}_{8}\right]\left[B A \mathrm{Br}_{4}\right]\right)$, where the second dehydrogenation is $1^{\text {st }}$ order $\left(k=3.1(2) \times 10^{-5} \mathrm{~s}^{-1}\right)$ and the first is either $1^{\text {st }}$ or $2^{\text {nd }}$ order. Initial concentration of dissolved samples $=12.5 \mathrm{mM}$ (conversion $=$ $0 \%)$. 


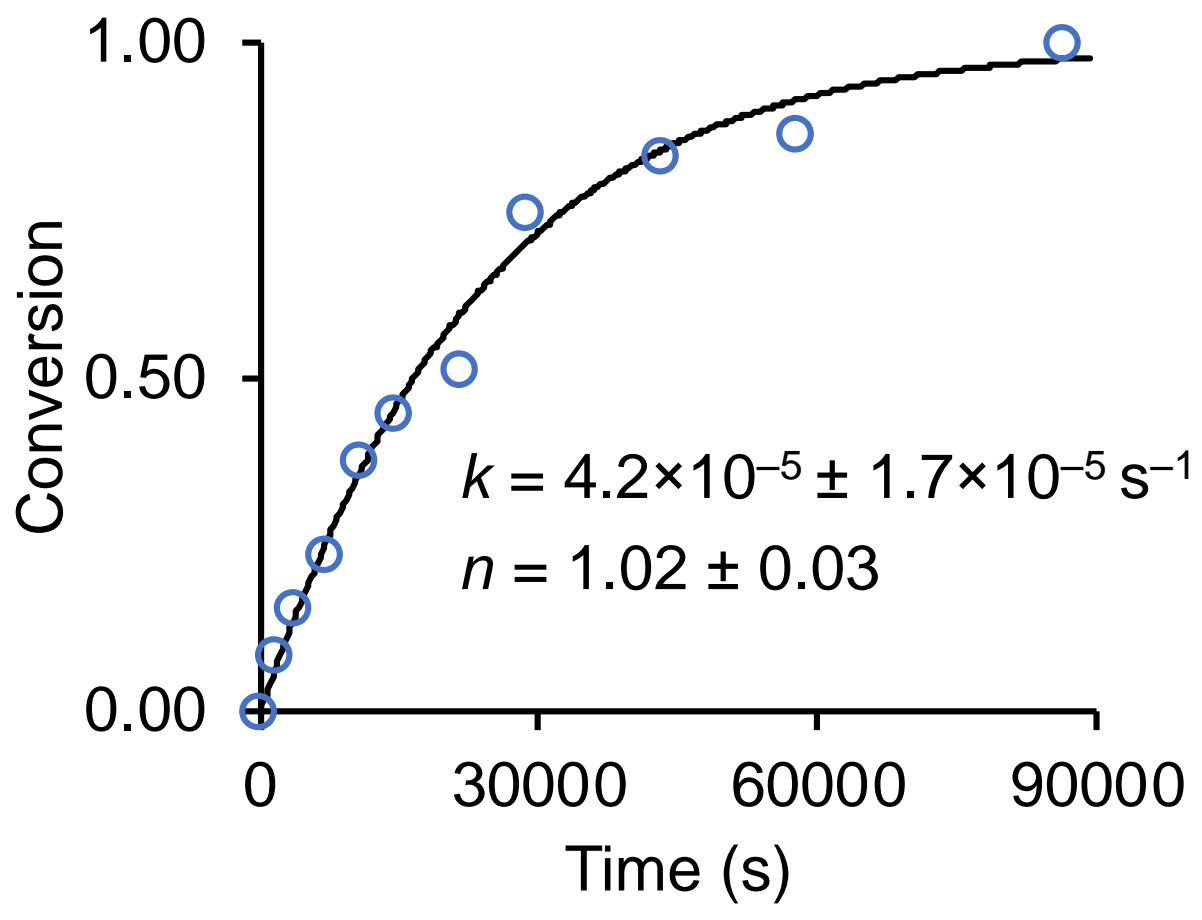

Figure S71: Modified JAMK Plot of conversion ${ }^{\mathrm{S9}}(\mathrm{f})=\left(1-\mathrm{e}^{\left.(-\mathrm{kt})^{2}\right)}\right.$ versus time for the dehydrogenation process $\left[1-\mathrm{C}_{6} \mathrm{H}_{10}\right]\left[\mathrm{BAr}_{4}\right]$ to $\left[1-\mathrm{C}_{6} \mathrm{H}_{8}\right]\left[\mathrm{BAr}_{4}\right]$ in the solid-state; which is the second dehydrogenation process of $\left[1-\mathrm{C}_{6} \mathrm{H}_{12}\right]\left[\mathrm{BAr}{ }_{4}\right]$. Where $k=$ growth rate constant and $n=$ Avrami exponent. 


\section{S.4.4. Solid-state dehydrogenation of $\left[1-\mathrm{C}_{6} \mathrm{H}_{12}\right]\left[B A \mathrm{Br}_{4}{ }_{4}\right]$ to form $\left[1-\mathrm{C}_{6} \mathrm{H}_{10}\right]\left[B A \mathrm{r}_{4}^{\mathrm{F}}\right]$ S.4.4.1. Solid-State Synthesis of $\left[1-\mathrm{C}_{6} \mathrm{H}_{10}\right]\left[\mathrm{BAr}_{4}{ }_{4}\right]$}
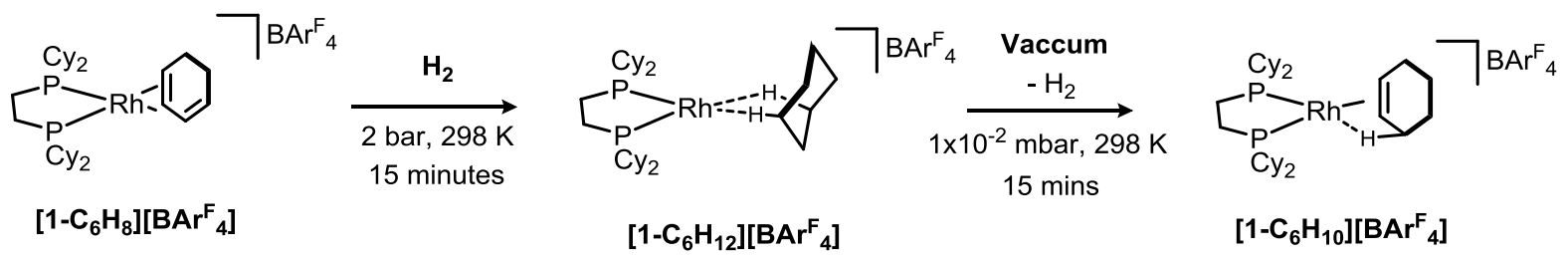

Attempts to trap [1- $\left.\mathbf{C}_{6} \mathbf{H}_{10}\right]\left[\mathbf{B A r}{ }_{4}{ }_{4}\right]$ in the solid-state were conducted using the following method:

A powdered microcrystalline sample of $\left[1-\mathrm{C}_{6} \mathrm{H}_{8}\right]\left[\mathrm{BAr}_{4}{ }_{4}\right](35 \mathrm{mg})$ was packed in a 3.2 $\mathrm{mm}$ SSNMR rotor, inside an argon filled glove box. The rotor was then placed in a custom built glass $\mathrm{J}$ Young flask ${ }^{\mathrm{S7}}$ and the sample was then exposed to $\mathrm{H}_{2}$ (1 bar, $298 \mathrm{~K}$ ) for 20 minutes, to yield deep red crystalline powder of [1- $\left.\mathrm{C}_{6} \mathrm{H}_{12}\right]\left[\mathrm{BAr}_{4}\right]$. The sample was then placed under a steady vacuum $\left(2 \times 10^{-2} \mathrm{mbar}\right)$ at $298 \mathrm{~K}$. After 15 minutes, the rotor cap was fitted under a flush of Ar, and immediately transferred to the bore of a SSNMR spectrometer and analyzed by ${ }^{31} \mathrm{P}\left\{{ }^{1} \mathrm{H}\right\}$ and ${ }^{13} \mathrm{C}\left\{{ }^{1} \mathrm{H}\right\}$ solid state NMR spectroscopy. 


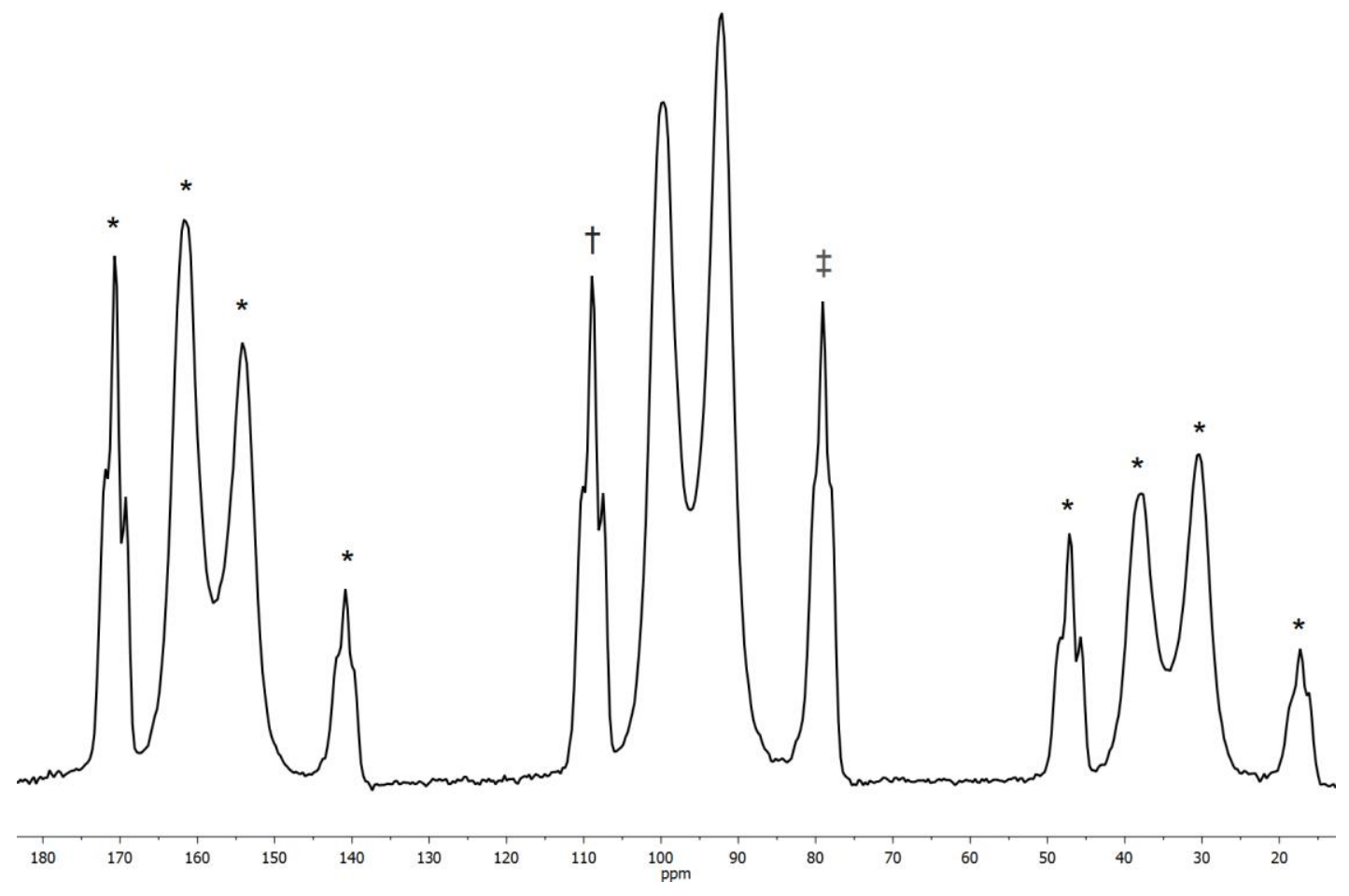

Figure S72: The ${ }^{31} \mathrm{P}\left\{{ }^{1} \mathrm{H}\right\}$ SSNMR (162 MHz, $295 \mathrm{~K}, 10 \mathrm{kHz}$ spin rate) spectrum of the dehydrogenation of powdered microcrystalline $\left[1-\mathbf{C}_{6} \mathbf{H}_{12}\right]\left[B \mathrm{Br}^{\mathrm{F}}{ }_{4}\right]$ under 15 minutes of vacuum. The resonances at $\delta 100$ and $\delta 92$ correspond to [1$\mathbf{C}_{6} \mathbf{H}_{10}$ ][BAr ${ }_{4}{ }_{4}$ ( $\left.70 \%\right)$, and the resonances $\dagger$ marked are assigned to [1$\left.\mathrm{C}_{6} \mathbf{H}_{12}\right]\left[\mathrm{BAr}_{4} \mathrm{~F}_{4}\right.$ ( $\left.15 \%\right)$ and the resonances marked $\ddagger(\sim 15 \%)$ are assigned to [1$\left.\mathrm{C}_{6} \mathrm{H}_{8}\right]\left[\mathrm{BAr}_{4}{ }_{4]}\right.$. The resonances marked ${ }^{*}$ are due to spinning sidebands.

We postulate this mixture of species arises in the solid-state from non-uniform vacuum being applied throughout the densely packed solid-state rotor, leading to slightly different kinetics then observed in Section S.4.3.3. 


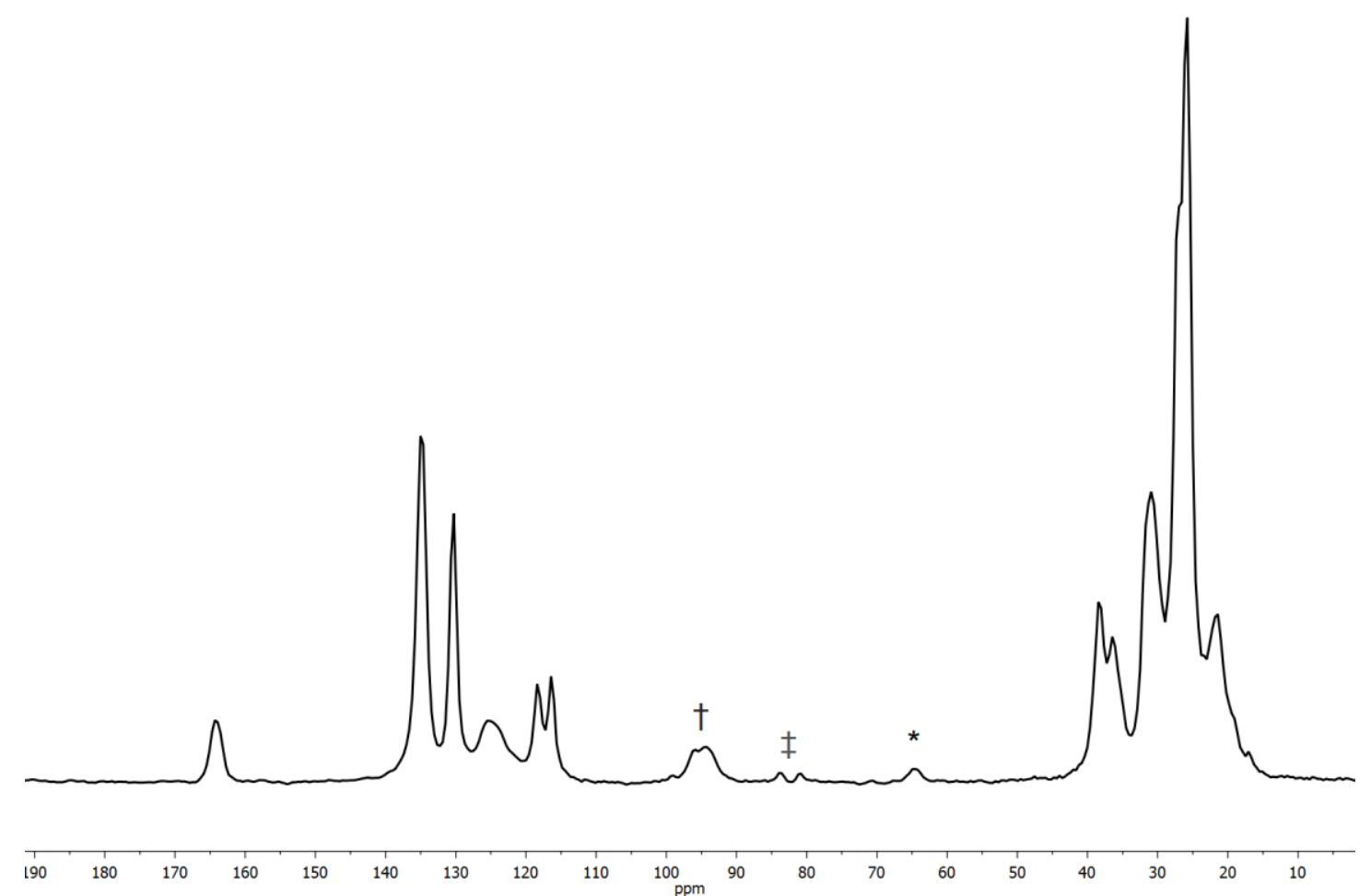

Figure S73: The ${ }^{13} \mathrm{C}\left\{{ }^{1} \mathrm{H}\right\}$ SSNMR $(100 \mathrm{MHz}, 295 \mathrm{~K}, 10 \mathrm{kHz}$ spin rate) spectrum of the dehydrogenation of powdered microcrystalline $\left[1-\mathbf{C}_{6} \mathbf{H}_{12}\right]\left[B \mathbf{B r}^{\mathrm{F}}\right]$ under 15 minutes of vacuum. The resonance marked $\dagger$ are from the carbons in alkene environments of [1-C $\left.\mathbf{C}_{6} \mathbf{H}_{10}\right]\left[\mathrm{BAr}_{4}{ }_{4}\right]$, and resonances $\ddagger$ marked are assigned to [1$\left.\mathrm{C}_{6} \mathrm{H}_{8}\right]\left[\mathrm{BAr}_{4}{ }_{4}\right.$ ], see Figure S22. The resonances marked ${ }^{*}$ are due to spinning sidebands.

\section{S.4.4.2. Isolation and solution-state characterization data for $\left[1-\mathrm{C}_{6} \mathrm{H}_{10}\right]\left[B A \mathrm{Br}_{4} \mathrm{~F}\right]$}

Attempts to trap [1- $\left.\mathrm{C}_{6} \mathrm{H}_{10}\right]\left[\mathrm{BAr}_{4}^{\mathrm{F}}\right.$ ] in solution were conducted using the following method:

A $J$ Young NMR tube was charge with powdered microcrystalline [1- $\left.\mathrm{C}_{6} \mathrm{H}_{8}\right]\left[\mathrm{BAr}{ }_{4}\right.$ ] (10 mg) in a glove box. The sample was then evacuated and backfilled with $\mathrm{H}_{2}$ (2 bar, $298 \mathrm{~K}$ ) for 15 minutes. The sample was then cooled to $77 \mathrm{~K}$ in liquid nitrogen and evacuated. After a steady vacuum was achieved $\left(2 \times 10^{-2} \mathrm{mbar}\right)$ the sample was rapidly warmed to $298 \mathrm{~K}$ and a timer was simultaneously started. After 15 minutes, the sample was cooled to $77 \mathrm{~K}$ in liquid nitrogen and $\mathrm{CH}_{2} \mathrm{Cl}_{2}(0.40 \mathrm{~mL})$ was condensed into the NMR tube. The sample was expediently thawed and rapidly transferred to the bore of a precooled (183 K) NMR spectrometer which was previously locked and shimmed to a sample of $\mathrm{CD}_{2} \mathrm{Cl}_{2} \cdot \mathrm{A}^{31} \mathrm{P}\left\{{ }^{1} \mathrm{H}\right\} \mathrm{NMR}$ spectrum was then acquired. 
${ }^{1} \mathrm{H}$ NMR $\left(\mathrm{CD}_{2} \mathrm{Cl}_{2}, 400 \mathrm{MHz}, 183 \mathrm{~K}\right.$, selected resonances): $\delta 7.72$ (s, 14H, ortho-ArH), 7.54 (s, 7H, para-ArH), 5.23 (s, 2H, alkene-CH), 2.47 (br d, J $\mathrm{J}_{\mathrm{HH}} 14 \mathrm{~Hz}$, cyclohexene- $\mathrm{CH}$ ), 2.05-1.38 (br m, 73H, overlapping aliphatic $\mathrm{CH}$ ), 1.30-0.98 (br m, $53 \mathrm{H}$, overlapping aliphatic $\mathrm{CH}$ ), -1.01 (br s, $2 \mathrm{H}$, agostic $\mathrm{CH}$ ).

Note: The low temperature limit was not reached at $183 \mathrm{~K}$, so integrated values are approximate. As well, the integrals of the $\left[\mathrm{BAr}_{4}\right]^{-}$and alkyl resonances are higher than expected presumably due to contamination decomposition products of [1$\mathrm{BAr}_{4}{ }_{4},{ }^{\mathrm{S} 2}\left[1-\left(\mathrm{CD}_{2} \mathrm{Cl}_{2}\right)_{n}\right]\left[\mathrm{BAr}{ }_{4}{ }^{\mathrm{S} 1}\right.$ and liberated cyclohexane.

${ }^{31} \mathrm{P}\left\{{ }^{1} \mathrm{H}\right\} \mathrm{NMR}\left(\mathrm{CD}_{2} \mathrm{Cl}_{2}, 162 \mathrm{MHz}, 183 \mathrm{~K}\right.$, selected resonances): $\delta 98.0$ (dd, J JhP 207 $\mathrm{Hz}, J_{P P} 24 \mathrm{~Hz}$ ), 91.5 (dd, JRhP $159 \mathrm{~Hz}, J_{P P} 24 \mathrm{~Hz}$ ).

${ }^{19} \mathrm{~F}\left\{{ }^{1} \mathrm{H}\right\} \mathrm{NMR}\left(\mathrm{CD}_{2} \mathrm{Cl}_{2}, 377 \mathrm{MHz}, 183 \mathrm{~K}\right.$, selected resonances): $\delta-62.9$ (s).

Note: Samples rapidly decomposed in solution at room temperature. The decomposition products [1- $\left.\mathrm{C}_{6} \mathrm{H}_{8}\right]\left[\mathrm{BAr}{ }_{4}{ }_{4}\right],\left[1-\mathrm{C}_{6} \mathrm{H}_{6}\right]\left[\mathrm{BAr}_{4}{ }_{4}\right],\left[1-\mathrm{BAr}_{4}{ }_{4}\right]$ and liberated cyclohexane were identified by ${ }^{1} \mathrm{H}$ and ${ }^{31} \mathrm{P}\left\{{ }^{1} \mathrm{H}\right\}$ NMR spectroscopy. 


\section{S.4.4.3. Solution NMR spectra of $\left[1-\mathrm{C}_{6} \mathrm{H}_{10}\right]\left[B \mathrm{Br}_{4}{ }_{4}\right]$}

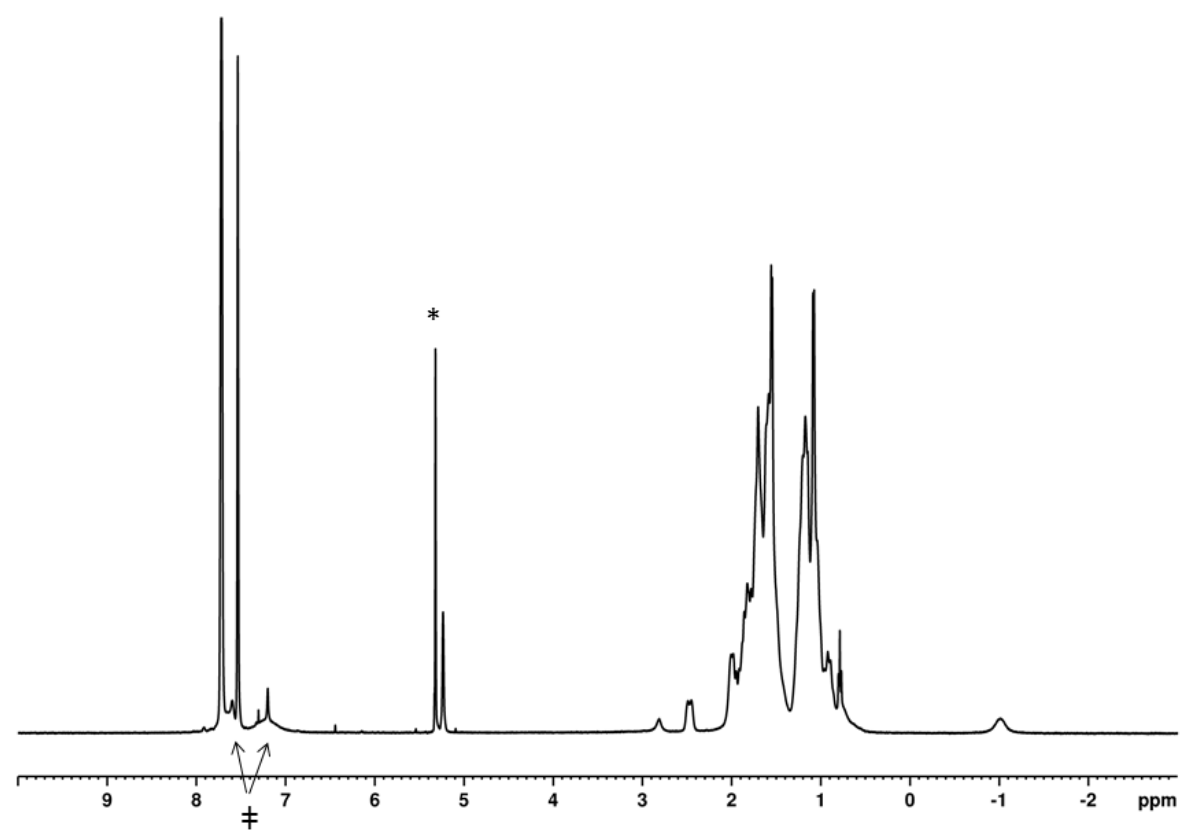

Figure S74: The solution ${ }^{1} \mathrm{H}$ NMR $\left(\mathrm{CD}_{2} \mathrm{Cl}_{2}, 183 \mathrm{~K}, 400 \mathrm{MHz}\right)$ spectrum of the intermediate stage of dehydrogenation. The resonance marked ${ }^{*}$ is due to $\mathrm{CHDCl}_{2}$. The resonances marked $\neq$ are tentatively assigned to [1-BAr${ }_{4}$ ].

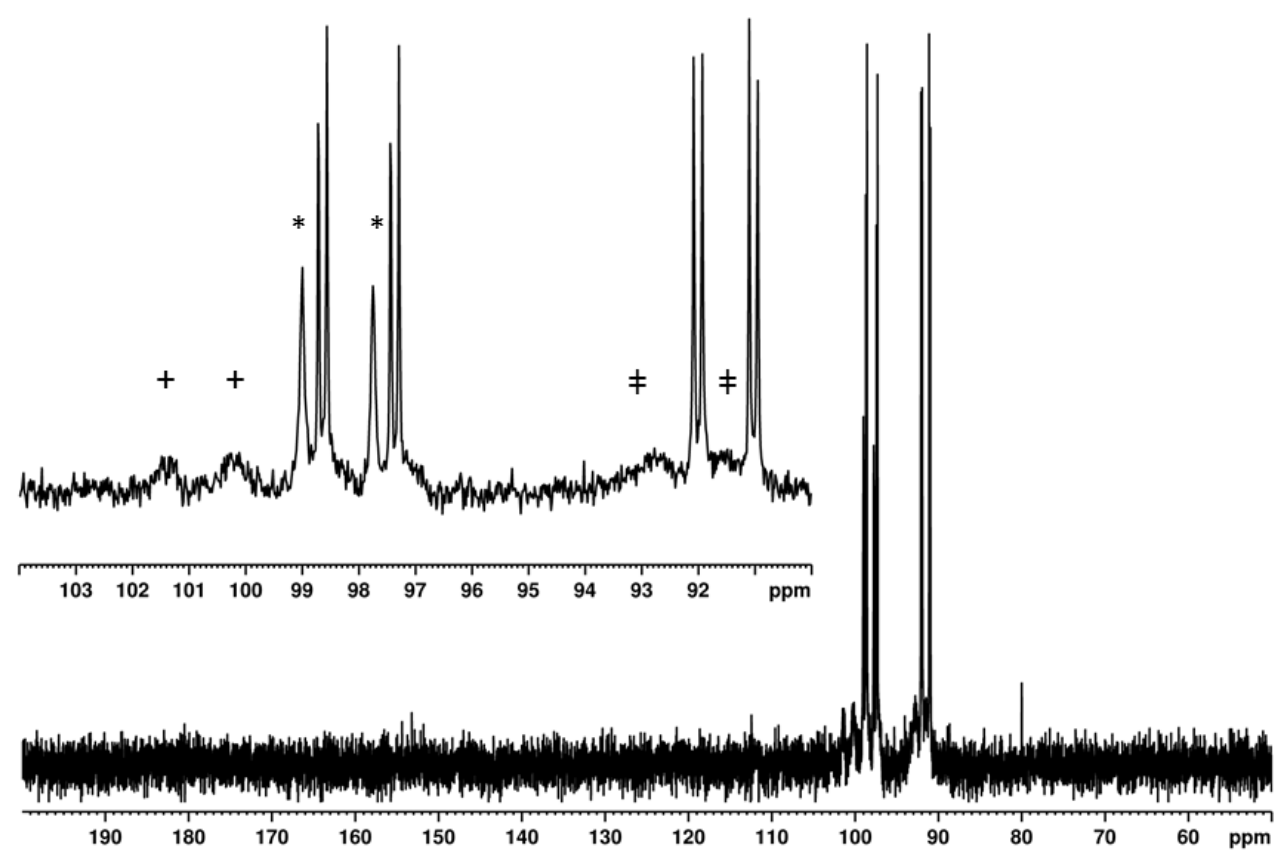

Figure S75: The ${ }^{31} \mathrm{P}\left\{{ }^{1} \mathrm{H}\right\}$ NMR $\left(\mathrm{CD}_{2} \mathrm{Cl}_{2}, 183 \mathrm{~K}, 162 \mathrm{MHz}\right)$ spectrum of the intermediate stage of dehydrogenation. The resonance marked * are tentatively assigned to [1-( $\left.\left.\mathrm{CD}_{2} \mathrm{Cl}_{2}\right)_{n}\right]\left[\mathrm{BAr}{ }_{4}\right]$. The resonances marked $\neq$ are assigned to [1BArF $_{4}{ }_{4}{ }^{\mathrm{S} 2}$ The resonances marked + could not be assigned. 


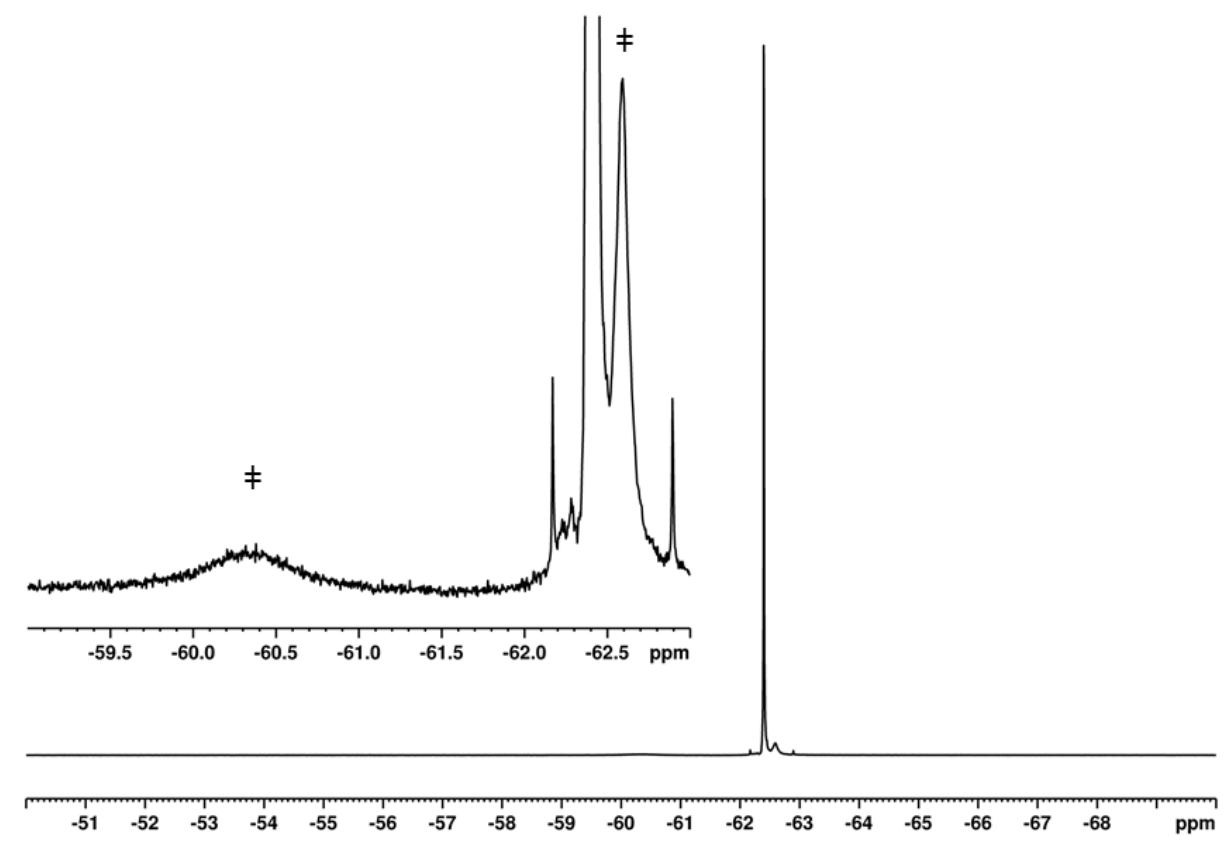

Figure S76: The ${ }^{19} \mathrm{~F}\left\{{ }^{1} \mathrm{H}\right\}$ NMR $\left(\mathrm{CD}_{2} \mathrm{Cl}_{2}, 183 \mathrm{~K}, 377 \mathrm{MHz}\right)$ spectrum of the intermediate stage of dehydrogenation. The inset is an enlargement of the baseline around the central resonance. The resonance marked $\neq$ is tentatively assigned to [1BArF $_{4}{ }_{4}$.

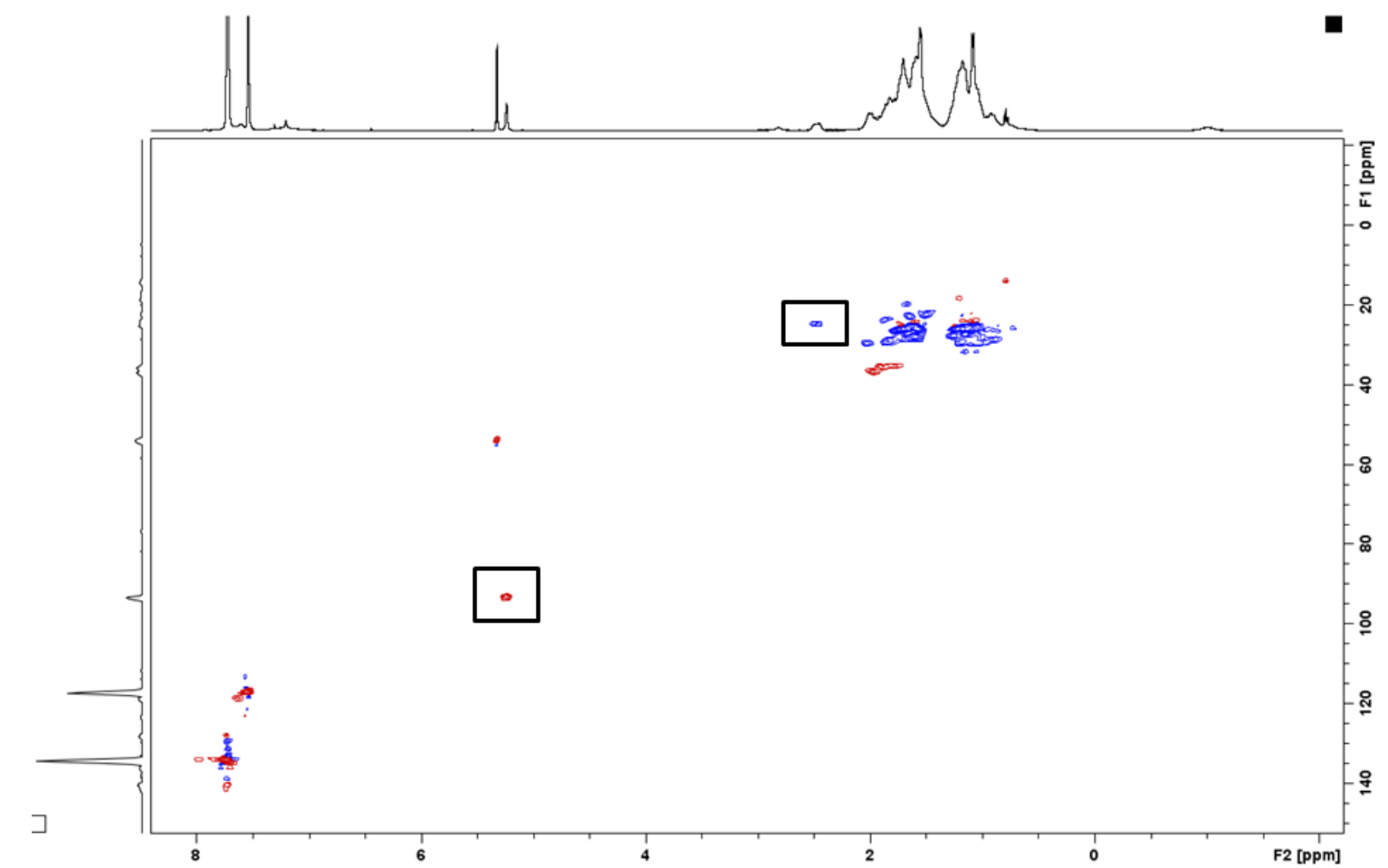

Figure S77: The solution ${ }^{1} \mathrm{H} /{ }^{13} \mathrm{C}$ HSQC NMR $\left(\mathrm{CD}_{2} \mathrm{Cl}_{2}, 183 \mathrm{~K}\right)$ spectrum of intermediate in the dehydrogenation. Black boxes added to guide the eye. A cross peak for the high field ${ }^{1} \mathrm{H}$ resonance was not unambiguously identified. 

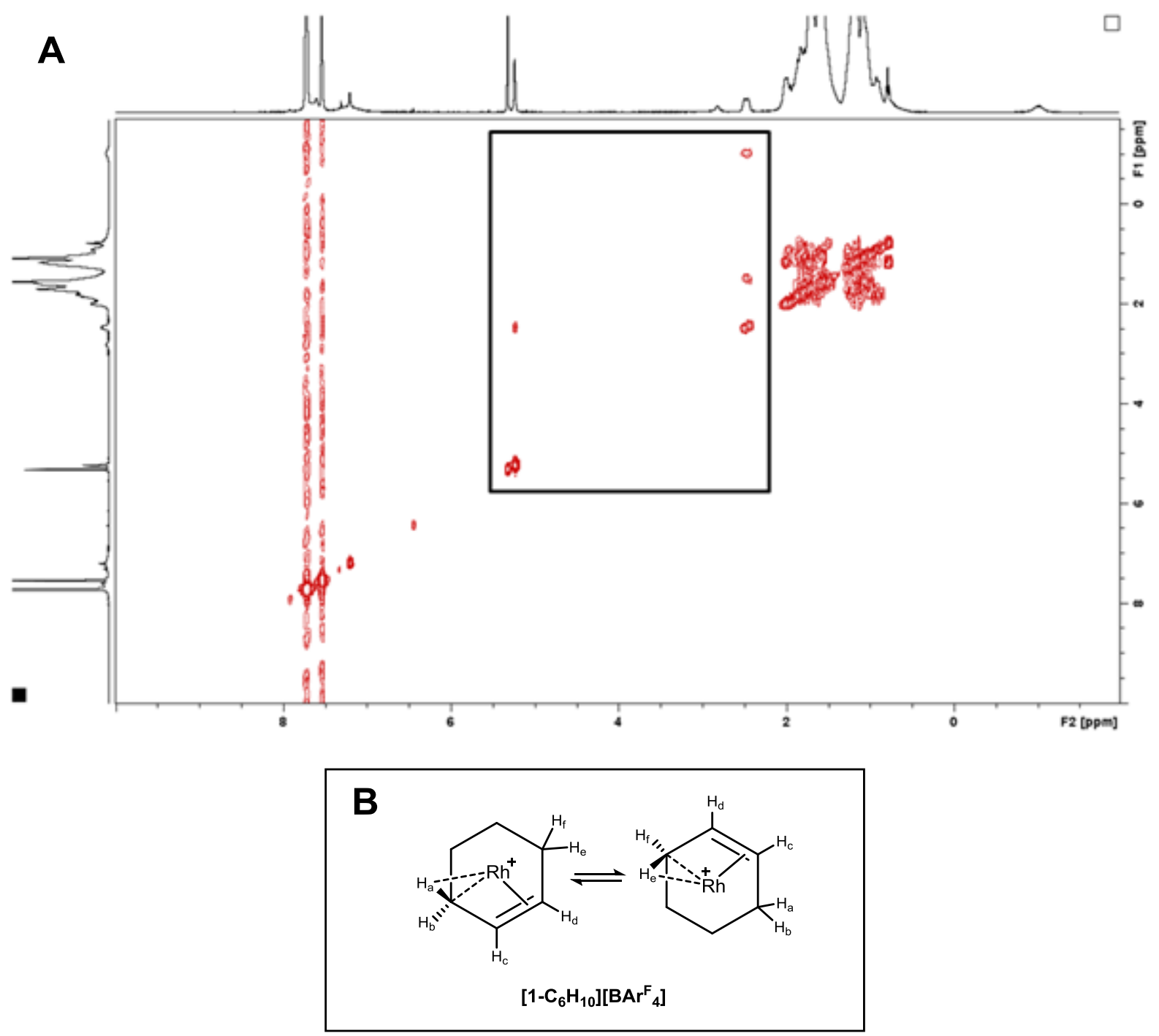

Figure S78: (A) The solution ${ }^{1} \mathrm{H} /{ }^{1} \mathrm{H}$ COSY NMR $\left(\mathrm{CD}_{2} \mathrm{Cl}_{2}, 183 \mathrm{~K}\right)$ spectrum of intermediate in the dehydrogenation. Black box added to guide the eye, showing ${ }^{1} \mathrm{H} /{ }^{1} \mathrm{H}$ correlation between agostic and alkene protons in $\left[1-\mathrm{C}_{6} \mathrm{H}_{10}\right]\left[\mathrm{BAr}_{4}^{\mathrm{F}}\right]$. (B) Structual diagrams of the fluxioanitly at room tempreture of $\left[1-\mathrm{C}_{6} \mathrm{H}_{10}\right]\left[\mathrm{BAr}{ }_{4}{ }_{4}\right.$; phosphine units and $\left[\mathrm{BAr}_{4}\right]^{-}$anions removed for clarity. 


\section{S.4.4.4. Liberation of the bound cyclohexene from $\left[1-\mathrm{C}_{6} \mathrm{H}_{10}\right]\left[B A \mathrm{Br}_{4}^{\mathrm{F}}\right]$.}

A $\mathrm{J}$ Young NMR tube was charge with powdered microcrystalline $\left[1-\mathrm{C}_{6} \mathrm{H}_{8}\right]\left[\mathrm{BAr}{ }_{4}\right]$ (10 mg) in a glove box. The sample was then evacuated and backfilled with $\mathrm{H}_{2}$ (2 bar, $298 \mathrm{~K}$ ). The sample was then cooled to $77 \mathrm{~K}$ in liquid nitrogen and evacuated. After a steady vacuum was achieved $\left(2 \times 10^{-2} \mathrm{mbar}\right)$ the sample was rapidly warmed to $298 \mathrm{~K}$ and a timer was simultaneously started. After $15 \mathrm{mins}$, the sample was cooled to $77 \mathrm{~K}$ in liquid nitrogen and $\mathrm{CH}_{2} \mathrm{Cl}_{2}(0.40 \mathrm{~mL})$ was condensed into the NMR tube. When thawing, care was taken such that the sample was not warmed above $233 \mathrm{~K}$. The cool sample was then carefully refilled with $\mathrm{CO}(1 \mathrm{bar}, 233 \mathrm{~K})$. After 5 minutes, a vibrant yellow solution had formed of $\left[\mathrm{Rh}(\mathrm{dcpe})(\mathrm{CO})_{2}\right]\left[\mathrm{BAr}{ }_{4]}\right]{ }^{\mathrm{S} 7}$ confirmed by solution ${ }^{31} \mathrm{P}\left\{{ }^{1} \mathrm{H}\right\}$ NMR spectroscopy $\left(\delta 85.22, \mathrm{~d}, J_{\mathrm{RhP}}=116 \mathrm{~Hz}\right.$ ), as well as liberated cyclohexene. The volatile component was then isolated by trap-to-trap distillation and analyzed by ${ }^{1} \mathrm{H}$ NMR spectroscopy and GC EI-MS.

${ }^{1} \mathrm{H}$ NMR $\left(\mathrm{CD}_{2} \mathrm{Cl}_{2}, 400 \mathrm{MHz}\right): \delta 5.66(\mathrm{~s}, 2 \mathrm{H}$, alkene-CH), 1.98 (br m, 4H, CH), 1.61 $(\mathrm{m}, 4 \mathrm{H}, \mathrm{CH})$. 


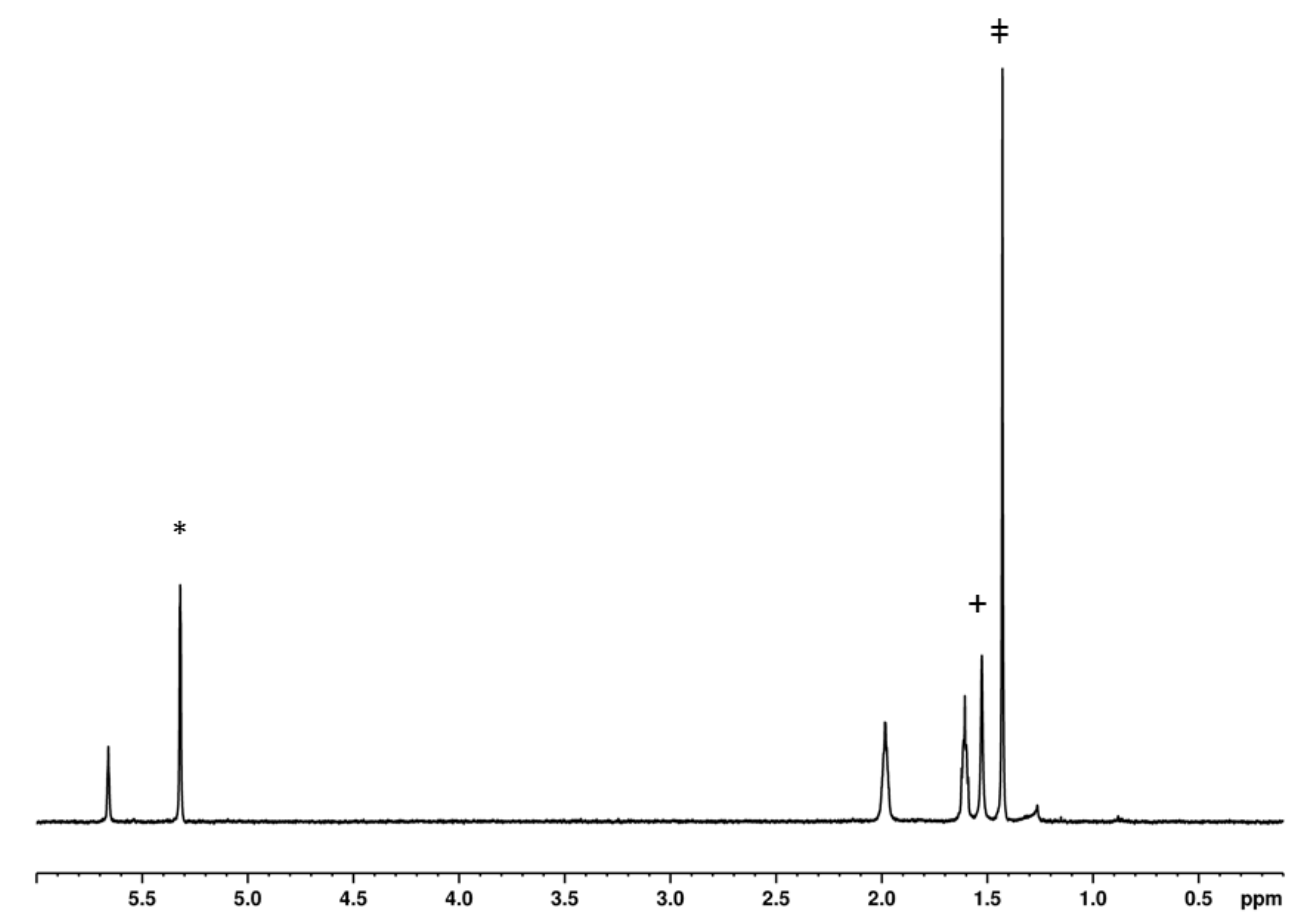

Figure S79: The ${ }^{1} \mathrm{H}$ NMR $\left(\mathrm{CD}_{2} \mathrm{Cl}_{2}, 298 \mathrm{~K}, 400 \mathrm{MHz}\right)$ spectrum of volatiles isolated post carbonylation. The resonance marked ${ }^{*}$ is due to $\mathrm{CHDCl}_{2}$. The resonance marked $\neq$ is assigned to cyclohexane. The resonance marked + is assigned to $\mathrm{H}_{2} \mathrm{O}$.

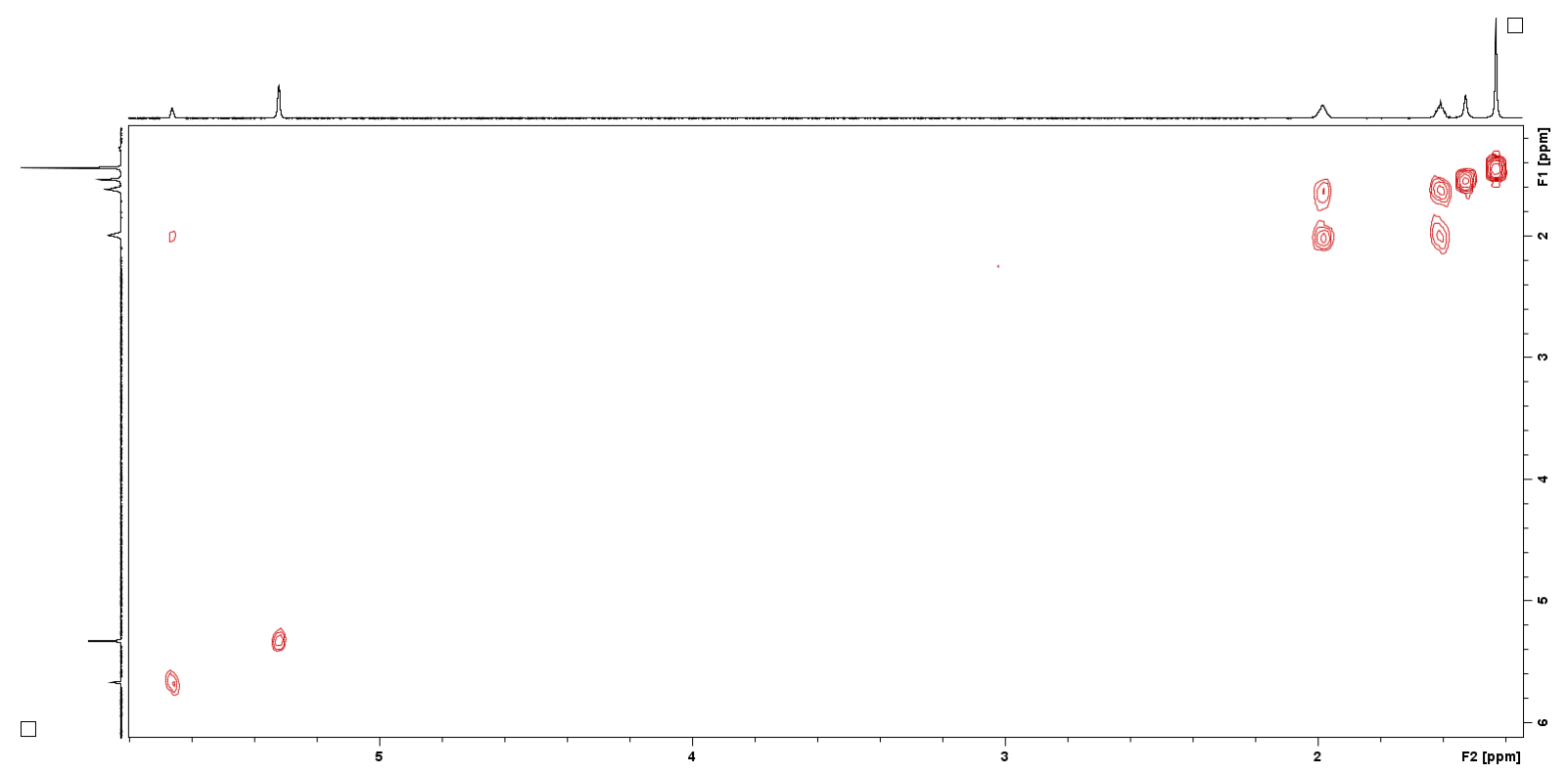

Figure S80: The ${ }^{1} \mathrm{H} /{ }^{1} \mathrm{H}$ COSY NMR $\left(\mathrm{CD}_{2} \mathrm{Cl}_{2}, 298 \mathrm{~K}, 400 \mathrm{MHz}\right)$ spectrum of volatiles isolated post carbonylation. 

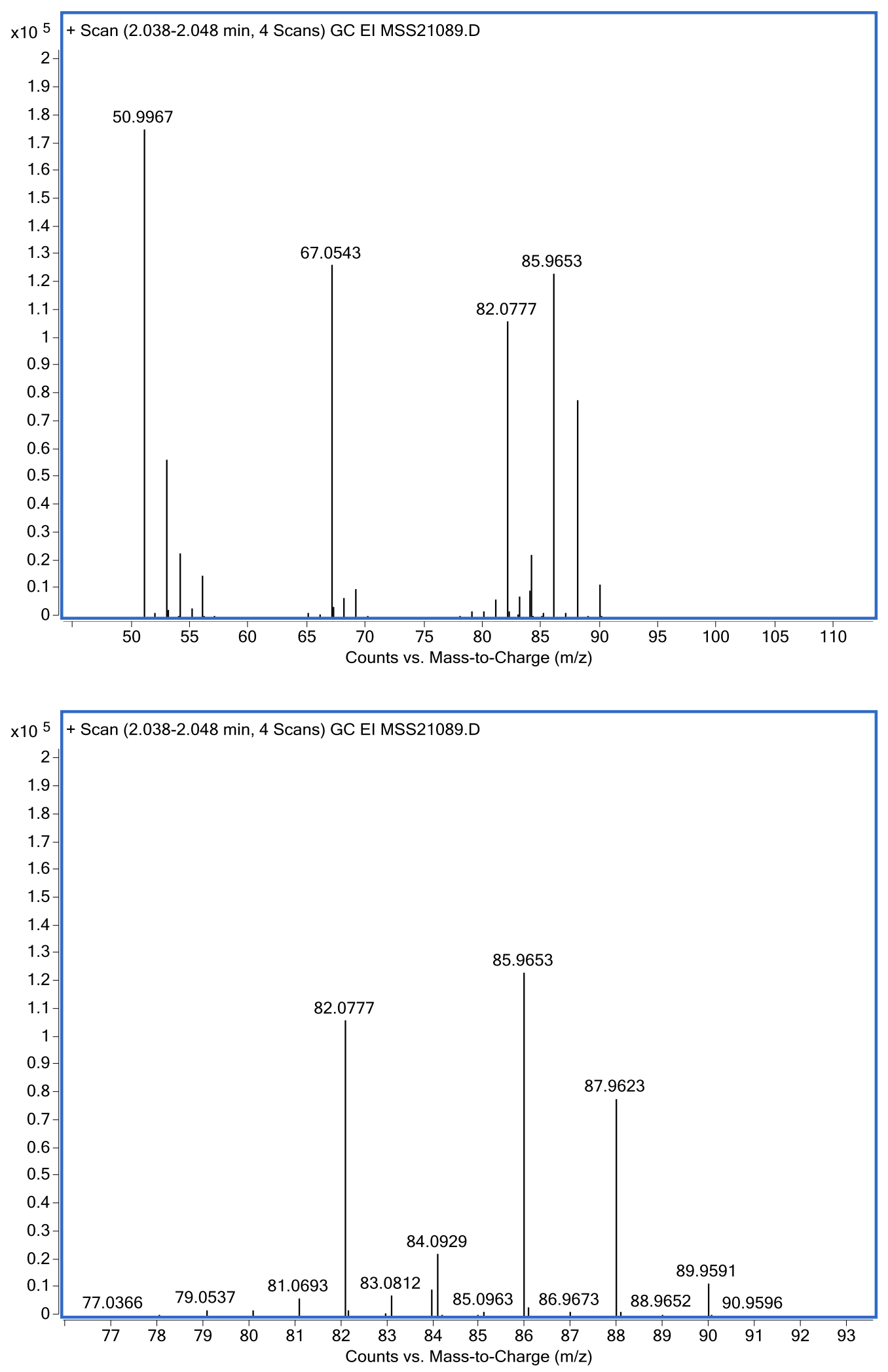

Figure S81: Mass spectrum of the isolated volatiles (top). Enlargement of $\mathrm{m} / \mathrm{z}=77-$ 93 region (bottom). The signal at $\mathrm{m} / \mathrm{z}=82.0777$ matches that of $\mathrm{C}_{6} \mathrm{H}_{10}$ (calc. 82.0777). The signal at $\mathrm{m} / \mathrm{z}=84.0929$ matches that of $\mathrm{C}_{6} \mathrm{H}_{12}$ (calc. 84.0933). Signals at $\mathrm{m} / \mathrm{z}=86$ and 88 are due to $\mathrm{CD}_{2} \mathrm{Cl}_{2}$. 

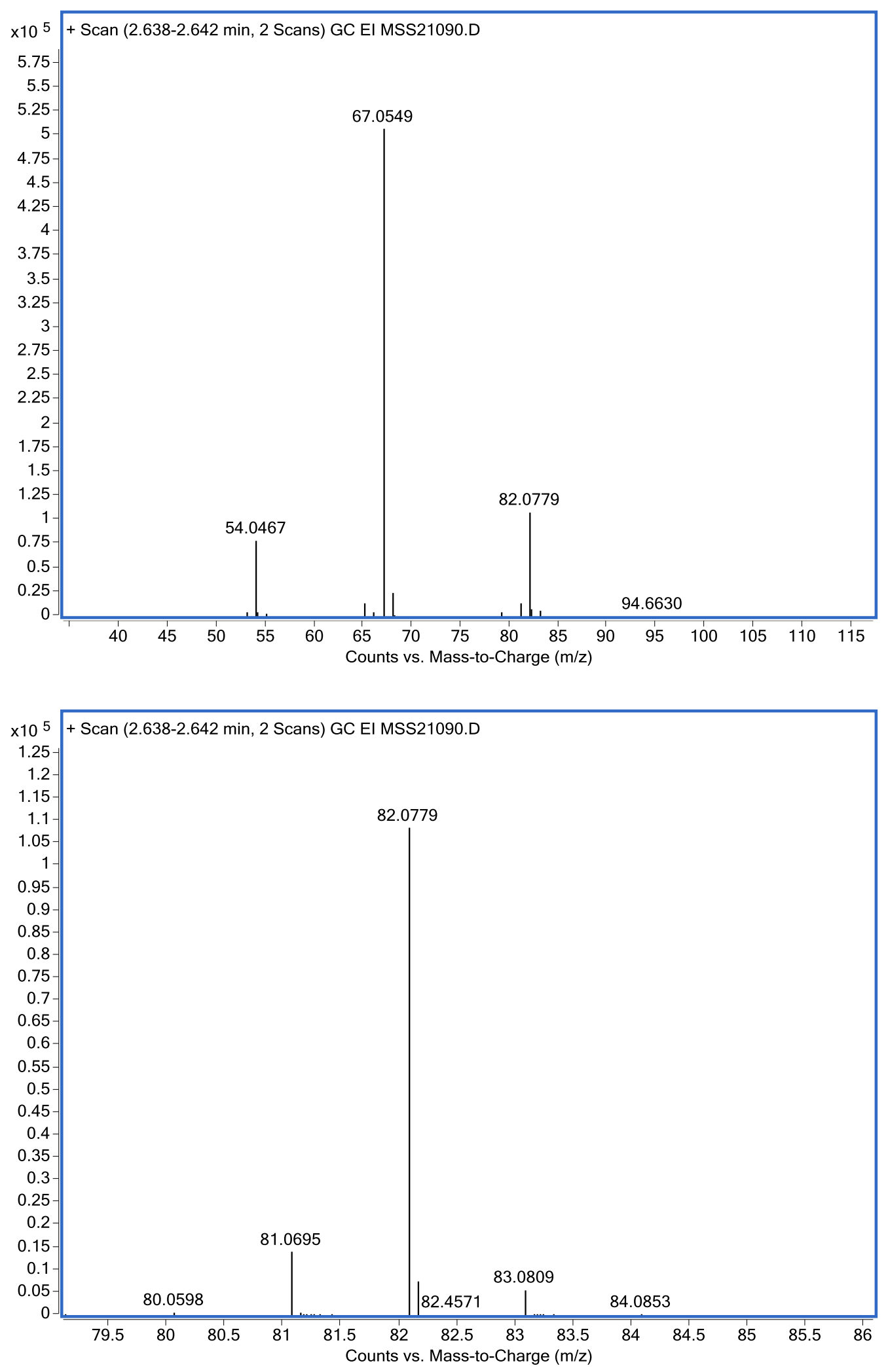

Figure S82: Mass spectrum of a commercially sourced sample of cyclohexene (top). Enlargement of $\mathrm{m} / \mathrm{z}=79-86$ region (bottom). 


\section{S.4.5. Solid state dedeuteration of $\left[1-\mathrm{C}_{6} \mathrm{D}_{12}\right]\left[\mathrm{BAr}{ }_{4}\right]$ under vacuum to form [1- $\left.\mathrm{C}_{6} \mathrm{D}_{8}\right]\left[\mathrm{BAr}{ }_{4}\right]$}

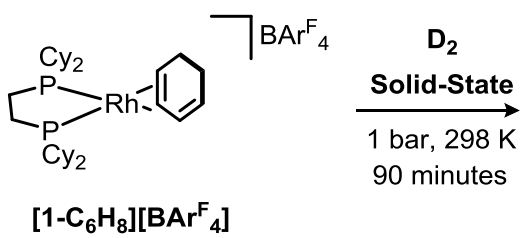

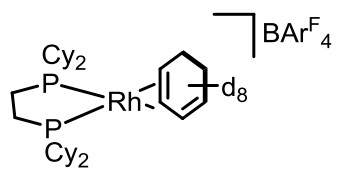

$\left[1-\mathrm{C}_{6} \mathrm{D}_{8}\right]\left[\mathrm{BAr}_{4} \mathrm{~F}\right.$

A thick walled NMR tube was charge with powdered microcrystalline [1- $\left.\mathbf{C}_{6} \mathbf{H}_{8}\right]\left[\mathbf{B A r}{ }_{4}\right.$ ] (10 mg) and sample was cooled to $77 \mathrm{~K}$ in liquid nitrogen, evacuated and backfilled with $D_{2}(1 \mathrm{bar}, 298 \mathrm{~K})$. After $30 \mathrm{~min}$, sample was then cooled to $77 \mathrm{~K}$ in liquid nitrogen, evacuated and backfilled with $D_{2}(1 \mathrm{bar}, 298 \mathrm{~K})$. This cycle was repeated once more, to give a total of $3 \times 30$ minute cycles, totaling 90 minutes under $D_{2}$. The sample was placed under a steady vacuum $\left(2 \times 10^{-2} \mathrm{mbar}\right)$, was rapidly warmed to $298 \mathrm{~K}$ and a timer was simultaneously started. After set periods of time (5 mins to approx. 3 days) the sample was cooled to $77 \mathrm{~K}$ in liquid nitrogen and $\mathrm{CH}_{2} \mathrm{Cl}_{2}(0.40$ $\mathrm{mL}$ ) was condensed into the NMR tube. The sample was expediently thawed and rapidly transferred to the bore of a precooled (183 K) NMR spectrometer which was previously locked and shimmed to a sample of $\mathrm{CD}_{2} \mathrm{Cl}_{2} \cdot \mathrm{A}^{31} \mathrm{P}\left\{{ }^{1} \mathrm{H}\right\}$ NMR spectrum was then acquired.

The above procedure was repeated on numerous occasions, varying the period of time the sample was exposed to vacuum at room temperature. 
S.4.5.1. Kinetics of the solid state dedeuteration of $\left[1-C_{6} D_{12}\right]\left[B \operatorname{Ar}_{4}\right]$ under vacuum to form $\left[1-\mathrm{C}_{6} \mathrm{D}_{8}\right]\left[\mathrm{BAr}{ }_{4}\right]$

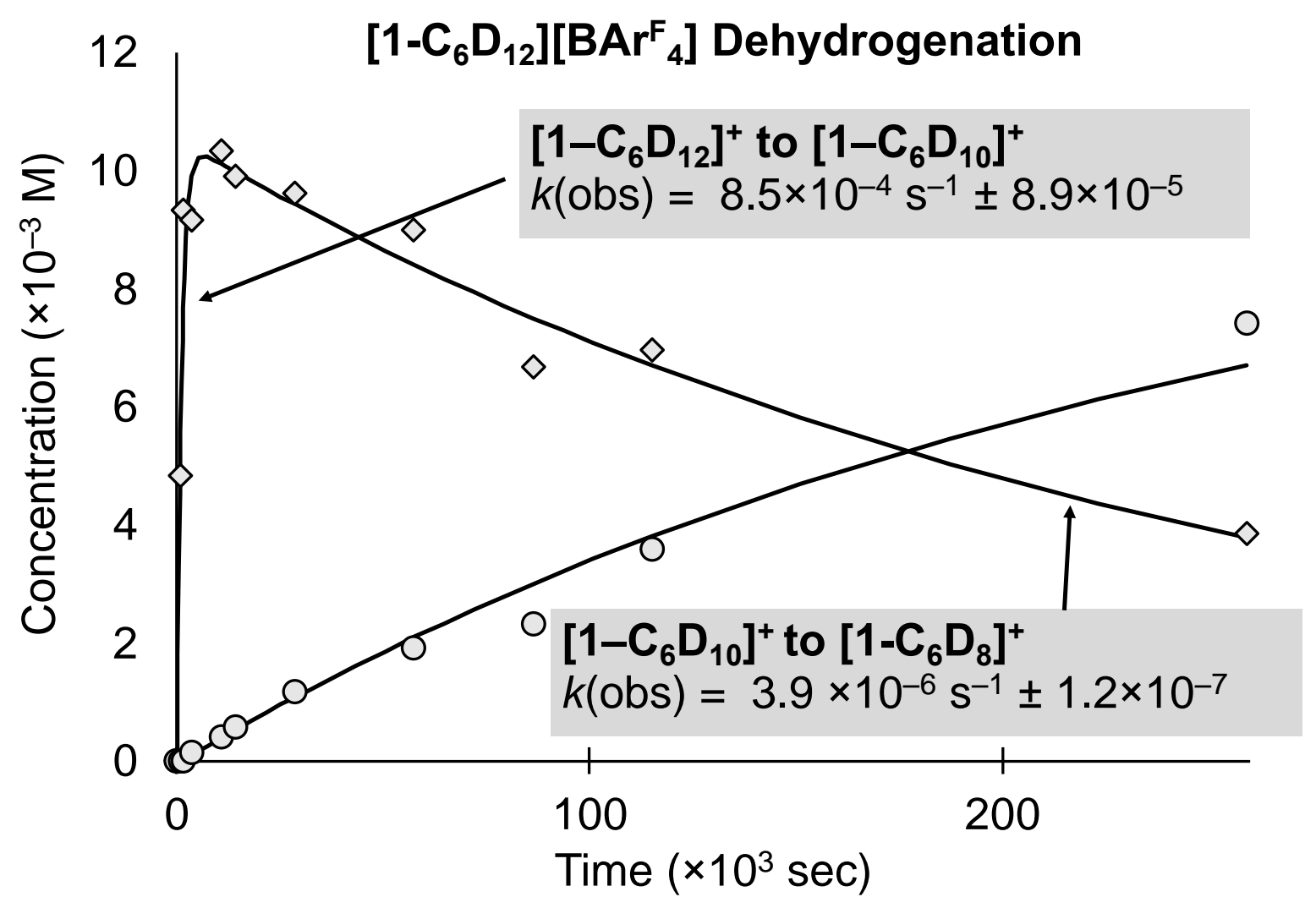

Figure S83: Temporal evolution of the dehydrogenation of $\left[1-\mathbf{C}_{6} \mathbf{D}_{12}\right]\left[\mathbf{B} \mathbf{A r}_{4}{ }_{4}\right]$ under vacuum $\left(1 \times 10^{-2} \mathrm{mbar}\right)$. A sample of $\left[1-\mathrm{C}_{6} \mathbf{D}_{12}\right]\left[\mathbf{B} \mathbf{A r}_{4}{ }_{4}\right]$ was initially prepared by

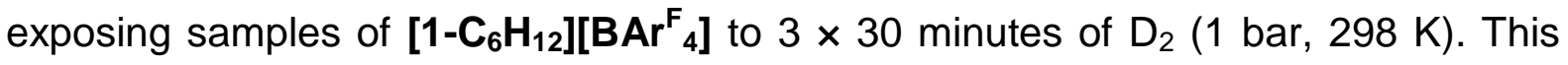
prolonged exposure resulted in a small but significant systematic decomposition of [1- $\left.\mathbf{C}_{6} \mathbf{H}_{12}\right]\left[B \mathbf{B r}^{\mathrm{F}}\right.$ ]. This shown by ${ }^{13} \mathrm{P}\left\{{ }^{1} \mathrm{H}\right\}$ SSNMR to be $\sim 10 \%$ (Section S.2.4.6.). The best COPASI simulated fits (both first order) agree well with this attenuation in $\left[1-\mathrm{C}_{6} \mathrm{D}_{12}\right]\left[\mathrm{BAr}_{4}^{\mathrm{F}}\right]$. 


\section{S.4.5.2. Characterization data for $\left[1-C_{6} D_{8}\right]\left[B A r^{F}\right]$}

${ }^{1} \mathrm{H}$ NMR $\left(\mathrm{CD}_{2} \mathrm{Cl}_{2}, 298 \mathrm{~K}, 400 \mathrm{MHz}\right): \delta 7.73$ (s, 8H, ortho-ArH), 7.57 (s, 4H, paraArH), 2.15 (br s, $2 \mathrm{H}$, aliphatic $\mathrm{CH}$ ), 1.99-1.66 (br m, 24H, overlapping aliphatic $\mathrm{CH}$ ), 1.61-1.58 (br m, $2 \mathrm{H}$, aliphatic $\mathrm{CH}$ ), 1.38-1.08 (br m, $16 \mathrm{H}$, overlapping aliphatic $\mathrm{CH}$ ), 0.99-0.96 (br m, 4H, overlapping aliphatic $\mathrm{CH}$ ).

${ }^{2} \mathrm{H}$ NMR $\left(\mathrm{CH}_{2} \mathrm{Cl}_{2}, 298 \mathrm{~K}, 61 \mathrm{MHz}\right): \delta 5.30$ (br s, 4D, alkene-CD), 1.76 (br s, 2D, aliphatic-CD), 1.62 (br s, 2D, aliphatic-CD).

${ }^{31} \mathrm{P}\left\{{ }^{1} \mathrm{H}\right\} \mathrm{NMR}\left(\mathrm{CD}_{2} \mathrm{Cl}_{2}, 298 \mathrm{~K}, 162 \mathrm{MHz}\right): \delta 78.7$ (d, J JhP $\left.172 \mathrm{~Hz}\right)$.

${ }^{19} \mathrm{~F}\left\{{ }^{1} \mathrm{H}\right\} \operatorname{NMR}\left(\mathrm{CD}_{2} \mathrm{Cl}_{2}, 298 \mathrm{~K}, 377 \mathrm{MHz}\right): \delta-62.9$ (s).

${ }^{13} \mathrm{C}\left\{{ }^{1} \mathrm{H}\right\} \operatorname{NMR}\left(\mathrm{CD}_{2} \mathrm{Cl}_{2}, 298 \mathrm{~K}, 126 \mathrm{MHz}\right): \delta 162.2$ (1:1:1:1 q, J JB $50 \mathrm{~Hz}$, ipso-ArC), 135.2 (s, ortho-ArC), 129.3 (q, J JF $32 \mathrm{~Hz}$, meta-ArC), 125.0 (q, J J $272 \mathrm{~Hz}, \mathrm{CF}_{3}$ ), 117.9 (s, para-ArC), 94.7 (1:1:1 t, J JD $26 \mathrm{~Hz}$, alkene-CD), $82.3\left(1: 1: 1 \mathrm{t}, \mathrm{J}_{\mathrm{CD}} 23 \mathrm{~Hz}\right.$, alkene-CD), 37.9 (dt, J $\mathrm{J}_{\mathrm{CP}} 24.4 \mathrm{~Hz}, \mathrm{~J}_{\mathrm{CRh}} 11.5 \mathrm{~Hz}$, cyclohexyl-CH), 37.0 (dt, J $\mathrm{J}_{\mathrm{CP}} 23.3$ $\mathrm{Hz}, \mathrm{J}_{\mathrm{CRh}} 11.4 \mathrm{~Hz}$, cyclohexyl-CH), 31.2 (s, cyclohexyl- $\mathrm{CH}_{2}$ ), 30.0 (s, cyclohexyl- $\mathrm{CH}_{2}$ ), 29.5 (s, cyclohexyl- $\mathrm{CH}_{2}$ ), 29.1 (s, cyclohexyl- $\mathrm{CH}_{2}$ ), 27.5 (t, JCP $6.4 \mathrm{~Hz}$, cyclohexyl$\mathrm{CH}_{2}$ ), $27.2\left(\mathrm{t}, \mathrm{J}_{\mathrm{CP}} 4.3 \mathrm{~Hz}\right.$, cyclohexyl- $\mathrm{CH}_{2}$ ), 27.0 (t, J JP $5.8 \mathrm{~Hz}$, cyclohexyl- $\mathrm{CH}_{2}$ ), 26.3 (d, J JP $18.6 \mathrm{~Hz}, \mathrm{PCH}_{2}$ ), 22.6 (d, J JP $3.4 \mathrm{~Hz}$, cyclohexyl-CH $\mathrm{CH}_{2}$ ), 22.5 (br s, cyclohexyl$\mathrm{CH}_{2}$ ), $22.3\left(\mathrm{~d}, \mathrm{~J}_{\mathrm{CP}} 3.2 \mathrm{~Hz}\right.$, cyclohexyl- $\left.\mathrm{CH}_{2}\right), 21.3\left(1: 2: 3: 2: 1\right.$ quintet, $\mathrm{J}_{\mathrm{CD}}=20 \mathrm{~Hz}$, $\mathrm{CD}_{2}$ ).

ESI-MS found (calc. for $\left.\left[\mathrm{Rh}\left(\mathrm{Cy}_{2} \mathrm{PCH}_{2} \mathrm{CH}_{2} \mathrm{PCy}_{2}\right)\left(\mathrm{C}_{6} \mathrm{D}_{8}\right)\right]^{+}\right)$: m/z 613.34 (613.34). 


\section{S.4.5.3. Solution NMR and mass spectra of $\left[1-C_{6} D_{8}\right]\left[B A r^{F}\right]$}

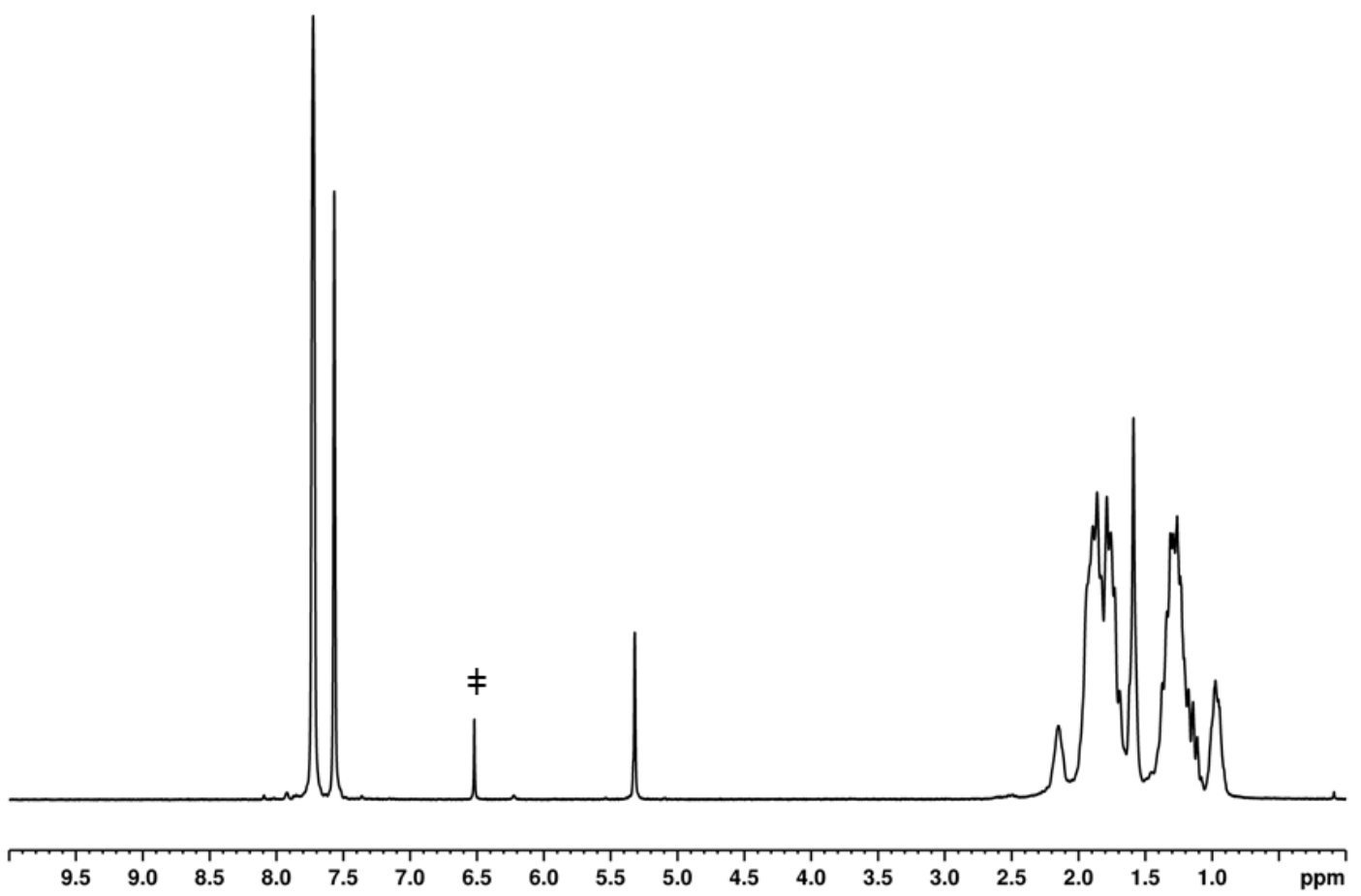

Figure S84: The solution ${ }^{1} \mathrm{H}$ NMR $\left(\mathrm{CD}_{2} \mathrm{Cl}_{2}, 298 \mathrm{~K}, 400 \mathrm{MHz}\right)$ spectrum of [1$\left.\mathrm{C}_{6} \mathrm{D}_{8}\right]\left[\mathrm{BAr}{ }_{4}{ }_{4}\right]$. The resonance marked $\ddagger$ is due to $\left[1-\mathrm{C}_{6} \mathrm{H}_{6}\right]\left[\mathrm{BAr}^{\mathrm{F}}{ }_{4}\right]$ which is present as a minor $(\sim 5 \%)$ contaminant in the $\left[1-\mathrm{C}_{6} \mathrm{H}_{8}\right]\left[\mathrm{BAr}{ }_{4}\right]$ starting material in this

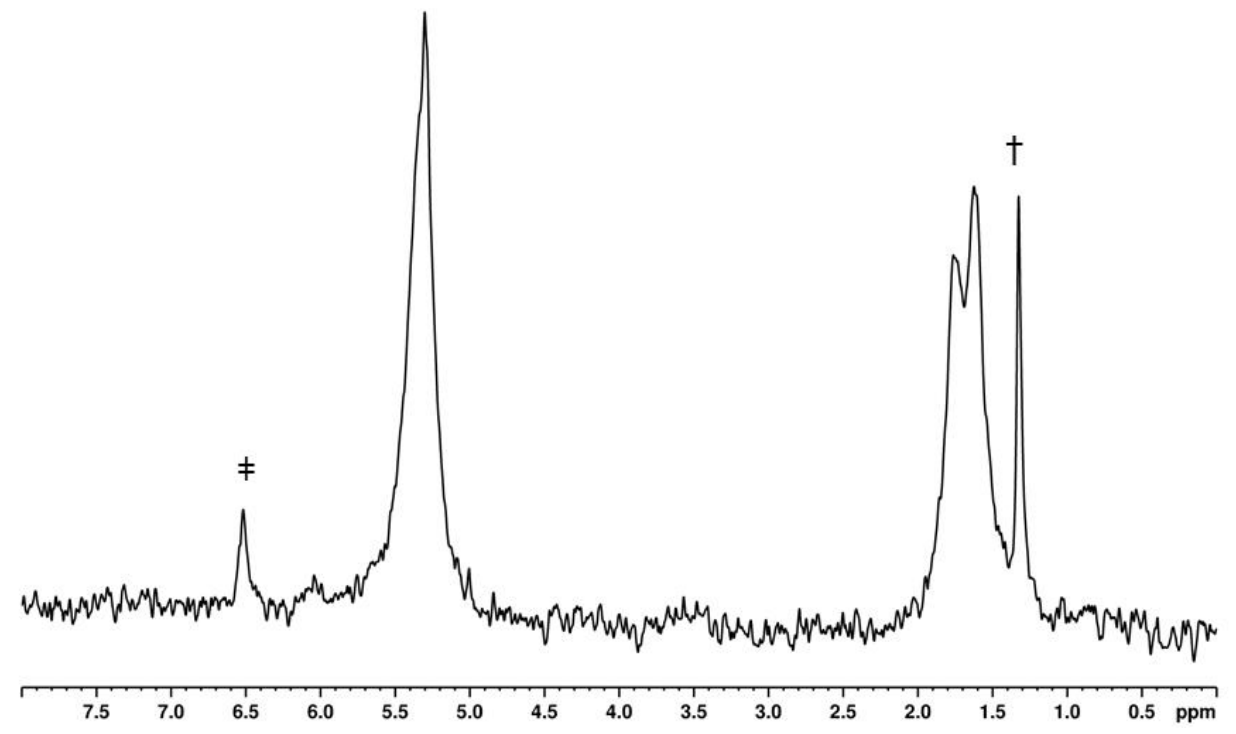

experiment.

Figure S85: The solution ${ }^{2} \mathrm{H}$ NMR $\left(\mathrm{CH}_{2} \mathrm{Cl}_{2}, 298 \mathrm{~K}, 61 \mathrm{MHz}\right)$ spectrum of [1$\left.\mathbf{C}_{6} \mathbf{D}_{8}\right]\left[\mathbf{B A r}{ }_{4}{ }_{4}\right.$. The resonances marked $\ddagger$ and $\dagger$ are due to $\left[1-\mathbf{C}_{6} \mathbf{D}_{6}\right]\left[\mathbf{B A r}{ }_{4}\right]$ and liberated $\mathrm{C}_{6} \mathrm{D}_{12}$ respectively, which arise due to the solution decomposition of [1$\left.\mathrm{C}_{6} \mathrm{D}_{8}\right]\left[\mathrm{BAr}_{4}\right]$ and incomplete dehydrogenation. 

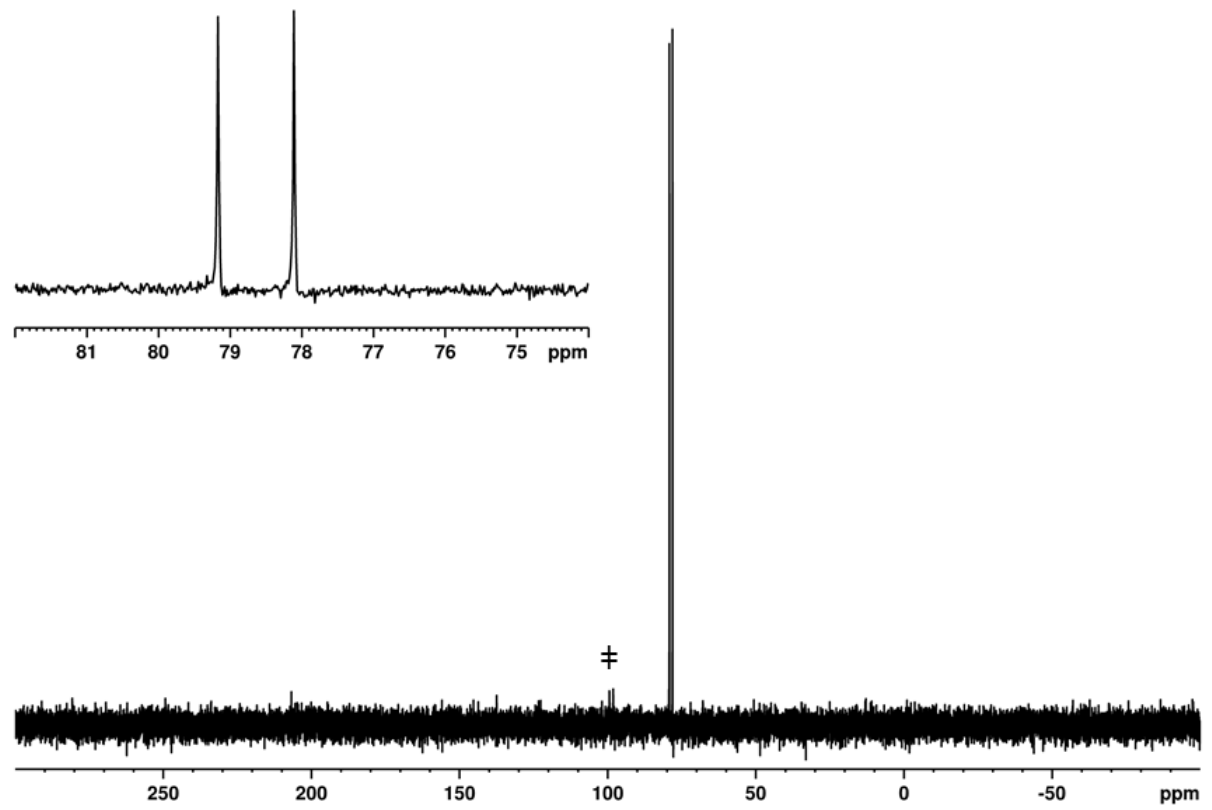

Figure S86: The solution ${ }^{31} \mathrm{P}\left\{{ }^{1} \mathrm{H}\right\}$ NMR $\left(\mathrm{CD}_{2} \mathrm{Cl}_{2}, 298 \mathrm{~K}, 162 \mathrm{MHz}\right)$ spectrum of [1-

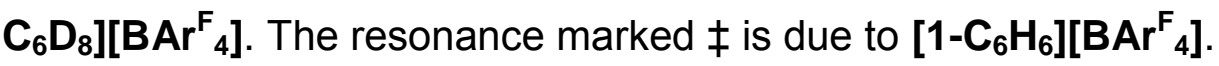

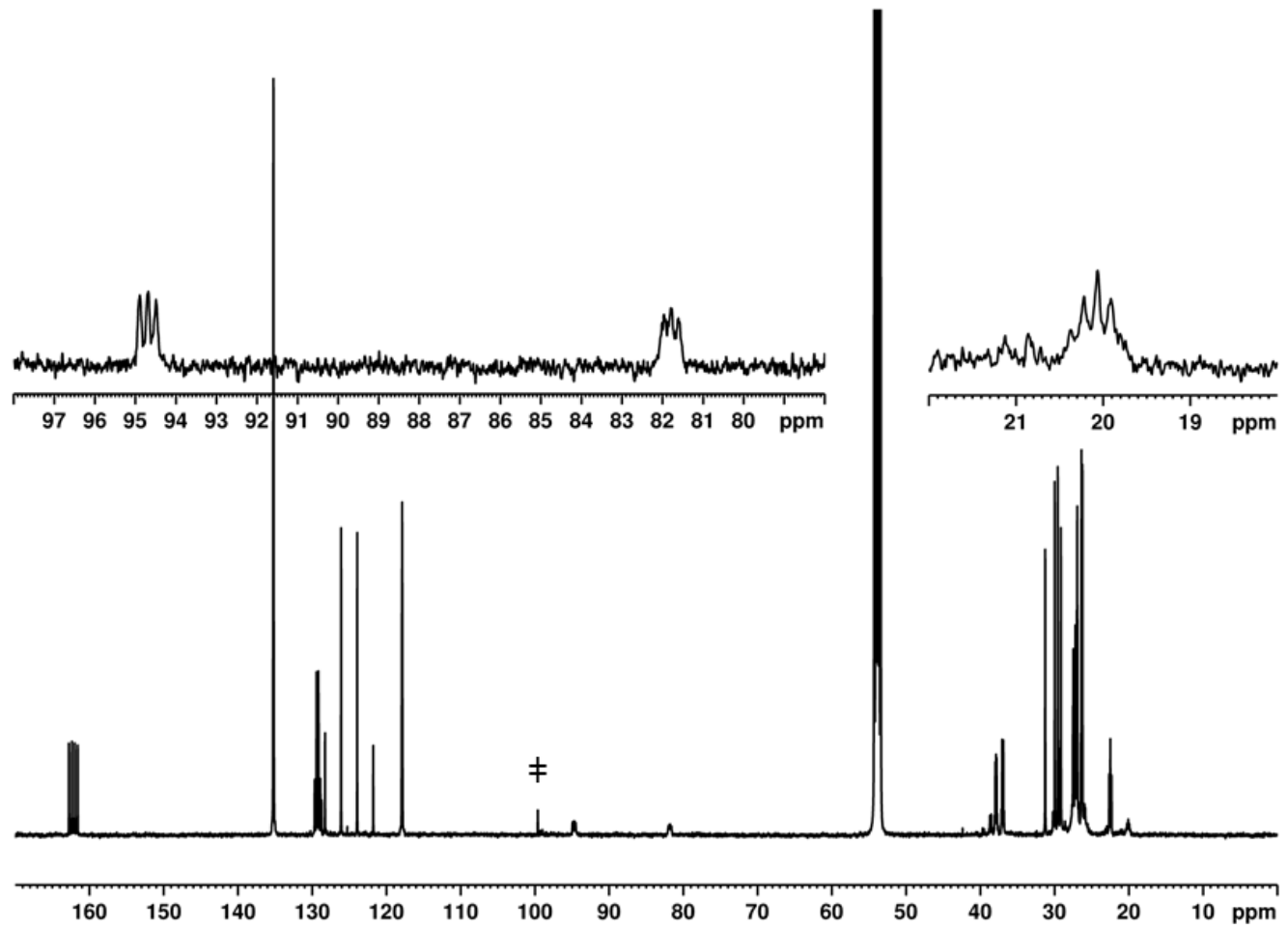

Figure S87: The solution ${ }^{13} \mathrm{C}\left\{{ }^{1} \mathrm{H}\right\}$ NMR $\left(\mathrm{CD}_{2} \mathrm{Cl}_{2}, 298 \mathrm{~K}, 126 \mathrm{MHz}\right)$ spectrum of [1$\left.\mathbf{C}_{6} \mathbf{D}_{8}\right]\left[B A r^{F_{4}}\right]$. The resonance marked $\ddagger$ is due to $\left[1-\mathbf{C}_{6} \mathbf{H}_{6}\right]\left[B A r^{F_{4}}\right]$. 


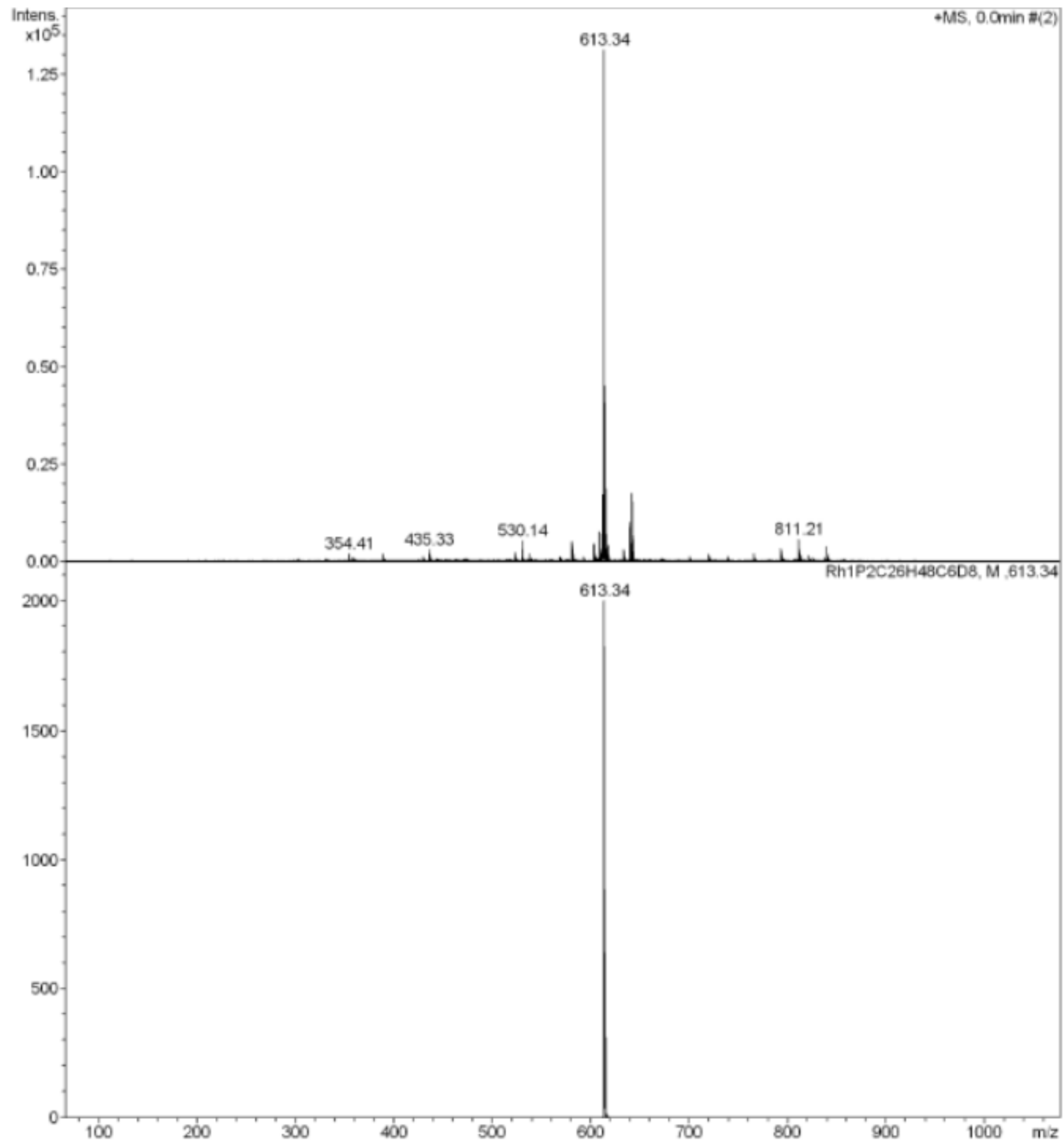

Figure S88: The experimental (top) and simulated (bottom) ESI mass spectra of [1$\left.\mathrm{C}_{6} \mathrm{D}_{8}\right]\left[\mathrm{BAr}_{4}{ }_{4}\right]$. 


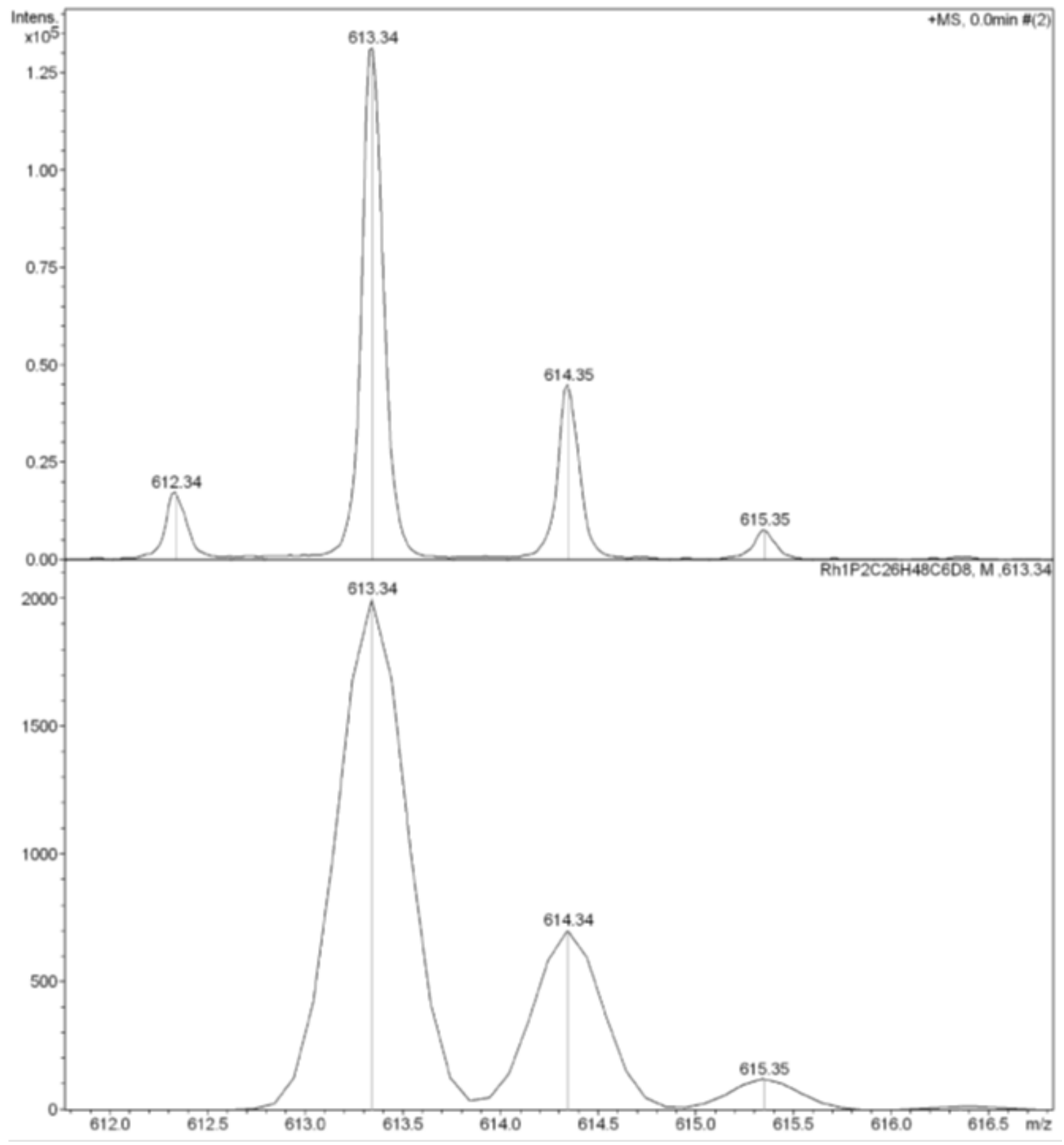

Figure S89: An enlargement of the ESI mass spectra of $\left[1-\mathrm{C}_{6} \mathrm{D}_{8}\right]\left[\mathrm{BAr}_{4}\right]$ showing the matching isotope patterns. The small peak at $\mathrm{m} / \mathrm{z}=612.34$ is $\left[1-\mathrm{C}_{6} \mathrm{HD}_{7}\right]^{+}$(calc. 612.34), which is presumably due to trace incomplete $H / D$ exchange. 


\section{S.4.5.4. Liberation of cyclohexadiene- $d_{8}$}

A $\mathrm{CD}_{2} \mathrm{Cl}_{2}$ or $\mathrm{CH}_{2} \mathrm{Cl}_{2}(0.4 \mathrm{~mL})$ solution of $\left[1-\mathrm{C}_{6} \mathrm{D}_{8}\right]\left[\mathrm{BAr}_{4}\right]$ in a $\mathrm{J}$ Young NMR tube was freeze-pump-thaw degassed three times. The sample was then carefully refilled with $\mathrm{CO}(1 \mathrm{bar}, 298 \mathrm{~K})$. Brief agitation of the sample resulted in a rapid change in the color of the solution from orange to yellow. The volatile component was then isolated by trap-to-trap distillation. The resultant solid was confirmed to be $\left[\mathrm{Rh}(\mathrm{dcpe})(\mathrm{CO})_{2}\right]\left[\mathrm{BAr}_{4}\right]$ by solution ${ }^{31} \mathrm{P}\left\{{ }^{1} \mathrm{H}\right\}$ NMR spectroscopy $\left(\delta 85.22, \mathrm{~d}, J_{\mathrm{RhP}}=116\right.$ $\mathrm{Hz}){ }^{\mathrm{S}}$

${ }^{2} \mathrm{H}$ NMR $\left(\mathrm{CH}_{2} \mathrm{Cl}_{2}, 298 \mathrm{~K}, 61 \mathrm{MHz}\right): \delta 5.91$ (s, 2D), 5.81 (s, 2D), 2.08 (s, 4D).

${ }^{13} \mathrm{C}\left\{{ }^{1} \mathrm{H}\right\} \operatorname{NMR}\left(\mathrm{CD}_{2} \mathrm{Cl}_{2}, 298 \mathrm{~K}, 126 \mathrm{MHz}\right): \delta 126.1$ (1:1:1 t, J JD $24.5 \mathrm{~Hz}$, alkene CD), $124.1\left(1: 1: 1 \mathrm{t}, \mathrm{J}_{\mathrm{CD}} 24.3 \mathrm{~Hz}\right.$, alkene $\left.\mathrm{CD}\right), 21.3$ (1:2:3:2:1 quintet, $\mathrm{J}_{\mathrm{CD}}=20 \mathrm{~Hz}, \mathrm{CD}_{2}$ ).

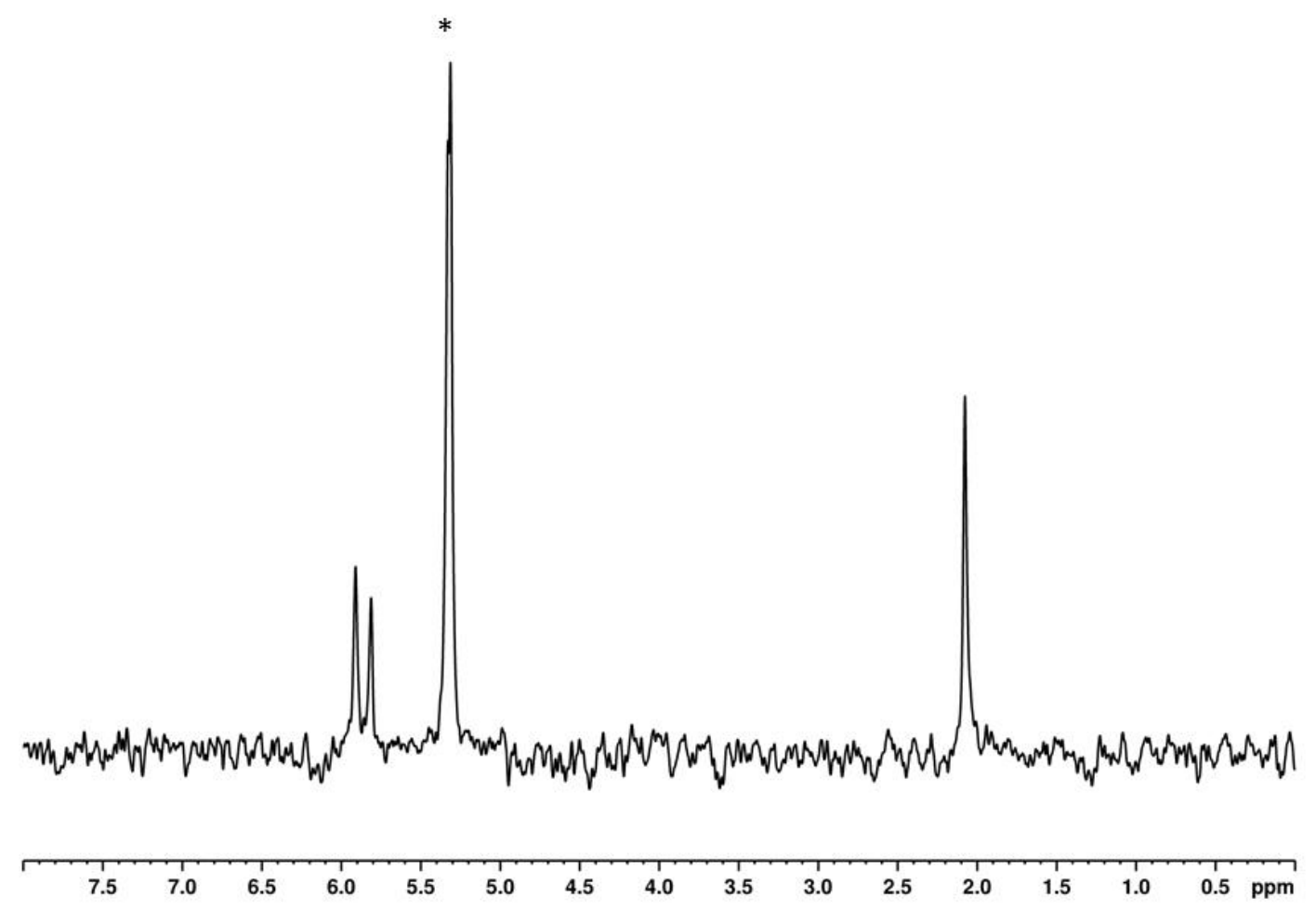

Figure S90: The solution ${ }^{2} \mathrm{H}$ NMR $\left(\mathrm{CH}_{2} \mathrm{Cl}_{2}, 298 \mathrm{~K}, 61 \mathrm{MHz}\right)$ spectrum of liberated alkene. The resonance marked * is due to $\mathrm{CHDCl}_{2}$. 

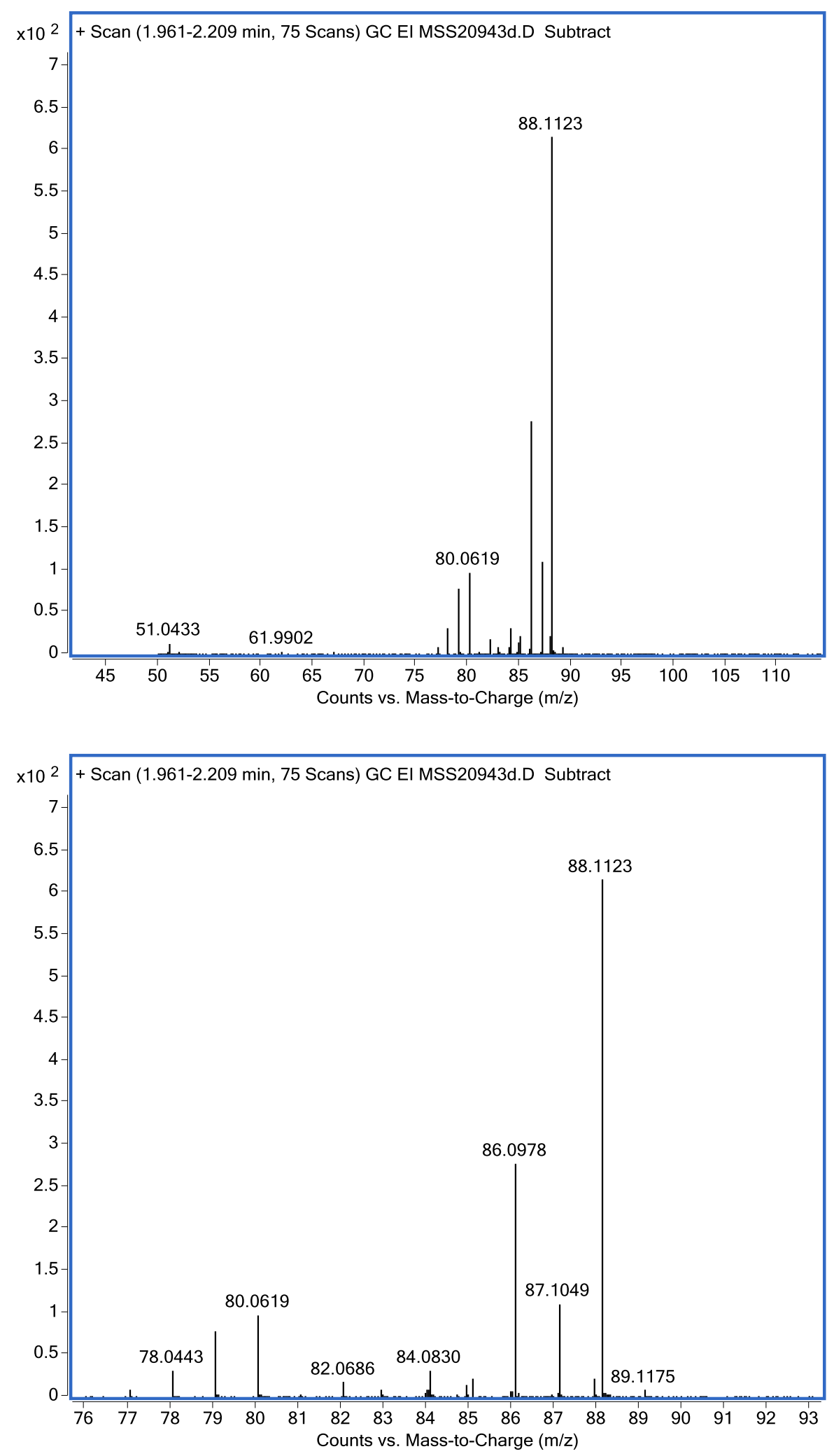

Figure S91: Mass spectrum of the isolated volatiles (top). Enlargement of $\mathrm{m} / \mathrm{z}=76-$ 93 region (bottom). The signal at $\mathrm{m} / \mathrm{z}=88.1123$ matches that of $\mathrm{C}_{6} \mathrm{D}_{8}$ (calc. 88.1123). The peak at $\mathrm{m} / \mathrm{z}=86.0978$ represents that of $\mathrm{C}_{6} \mathrm{D}_{8}-\mathrm{D}$ (calc. 86.0987). 

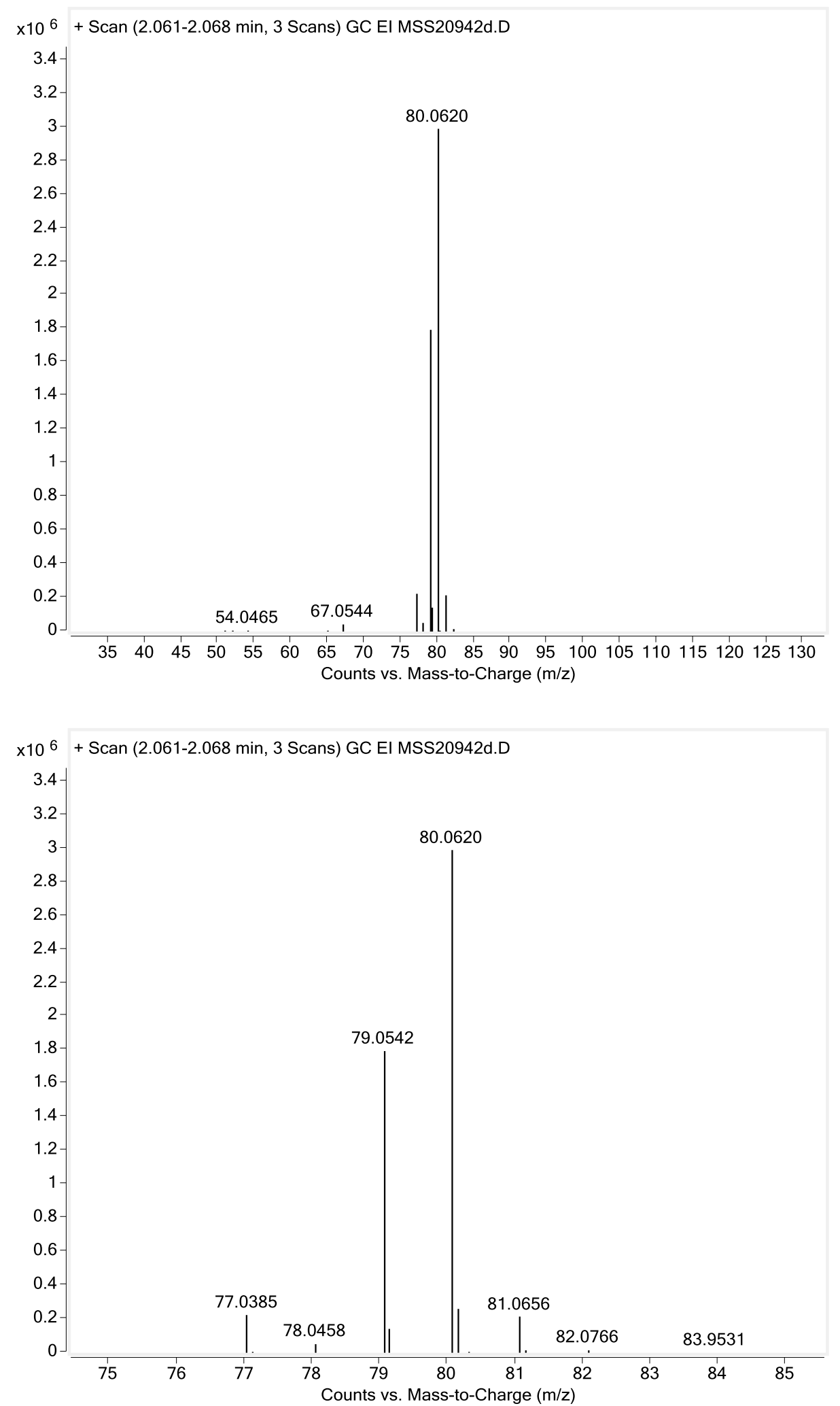

Figure S92: Mass spectrum of a commercially sourced sample of 1,3cyclohexadiene (top). Enlargement of $\mathrm{m} / \mathrm{z}=75-85$ region (bottom). The signal at $\mathrm{m} / \mathrm{z}=80.0620$ matches that of $\mathrm{C}_{6} \mathrm{H}_{8}{ }^{+}$(calc. 80.0626). The peak at $\mathrm{m} / \mathrm{z}=79.0542$ represents the $\mathrm{C}_{6} \mathrm{H}_{7}{ }^{+}$(calc. 79.0548). 


\section{S.5. Crystallographic and refinement data}

\section{S.5.1. Crystal structure determinations}

Single crystal X-ray diffraction data for all samples were collected as follows: a typical crystal was mounted on a MiTeGen Micromounts using perfluoropolyether oil and cooled rapidly to the collection temperature in a stream of nitrogen gas using an Oxford Cryosystems Cryostream unit. ${ }^{\text {S11 }}$ The structures of [1- $\left.\mathbf{C}_{4} \mathbf{H}_{8}\right]\left[\mathrm{BAr}_{4}{ }_{4}\right](150 \mathrm{~K})$, $\left[1-\mathrm{C}_{4} \mathrm{H}_{10}\right]\left[B \mathrm{Br}_{4}{ }_{4}\right](100 \mathrm{~K}) \&\left[1-\mathrm{C}_{6} \mathrm{H}_{12}\right]\left[B \mathrm{Br}^{\mathrm{F}}\right](150 \mathrm{~K})$ were collected at the Oxford Chemical Crystallography Service from the University of Oxford, with an Agilent SuperNova diffractometer ( $\mathrm{Cu} \mathrm{K}$ radiation, $\lambda=1.54180 \AA$ ). $\left[1-\mathrm{C}_{6} \mathrm{H}_{8}\right]\left[\mathrm{BAr}_{4}{ }_{4}\right](250 \mathrm{~K})$ was collected at the National Crystallography Service, University of Southampton, Southampton, UK, using a Rigaku 007HF diffractometer equipped with Varimax confocal mirrors ( $\mathrm{Cu} \mathrm{K}_{\alpha}$ radiation, $1.54184 \AA$ ), an AFC11 goniometer, and HyPix 6000 detector.

Raw frame data were reduced using CrysAlisPro. ${ }^{\mathrm{S} 12}$ The structures were solved using SHELXT ${ }^{\mathrm{S} 13}$ and refined using full-matrix least squares refinement on all $F^{2}$ data using the SHELXL-18 ${ }^{\mathrm{S} 14}$ using the interface OLEX2. ${ }^{\mathrm{S} 15}$ All hydrogen atoms were placed in calculated positions (riding model). Disorder of the $-\mathrm{CF}_{3}$ groups was treated by introducing a split site model and restraining geometries and displacement parameters.

\section{S.5.2. Additional comments crystal structures and refinement data}

\section{$\left[1-\mathrm{C}_{4} \mathrm{H}_{10}\right]\left[\mathrm{BAr}_{4}{ }_{4}\right]$}

In reply to A-Level Alert [PLAT971_ALERT_2_A]: The origin of this residual electron density relates to a positional disorder affecting a dicyclohexylphosphino group from the 1,2-Bis(dicyclohexylphosphino)ethane phosphine ligand from the asymmetric unit. This is too small contribution to be satisfactorily modelled. As such it was deemed better to retain this electron density with a low $\mathrm{R}$-factor.

In reply to B-Level Alert 3 [PLAT910_ALERT_3_B]: The sequential single-crystal to single-crystal transformation caused a loss in data quality at high angles. Because of 
this data set was collected to satisfy a sine(theta_max)/wavelength 0.82 giving an acceptable R-factor.

In reply to B-Level Alerts 2 [PLAT971_ALERT_2_B], [PLAT971_ALERT_2_B] and [PLAT973_ALERT_2_B]: The origin of this residual electron density relates to a positional disorder affecting a dicyclohexylphosphino group from the 1,2Bis(dicyclohexylphosphino)ethane phosphine ligand from the asymmetric unit. This is too small contribution to be satisfactorily modelled. As such it was deemed better to retain this electron density with a low R-factor.

\section{$\left[1-\mathrm{C}_{4} \mathrm{H}_{8}\right]\left[\mathrm{BAr}_{4} \mathrm{~F}^{\mathrm{S}} \mathrm{SC}-\mathrm{SC}\right.$ :}

In reply to A-Level Alert [PLAT029_ALERT_3_A]: The sequential two single-crystal to single-crystal transformations caused a loss in data quality. Because of this, this data set was collected to satisfy an acceptable atom connectivity model only.

In reply to B-Level Alert [THETM01_ALERT_3_B]: The sequential two single-crystal to single-crystal transformations caused a loss in data quality at high angles. Because of this, this data set was collected to satisfy a sine(theta_max)/wavelength of 0.56 giving a model for atom connectivity with an acceptable R-factor.

In reply to B-Level Alert [PLAT023_ALERT_3_B]: The sequential two single-crystal to single-crystal transformations caused a loss in data quality. Because of this, this data set was collected to satisfy an acceptable atom connectivity model only.

In reply to B-Level Alert [PLAT088_ALERT_3_B]: The sequential two single-crystal to single-crystal transformations caused a loss in data quality. Because of this, the data/parameter ratio is acceptable.

In reply to B-Level Alert [PLAT911_ALERT_3_B]: The sequential two single-crystal to single-crystal transformations caused a loss in data quality. Because of this, this data set was collected to satisfy an acceptable atom connectivity model only.

\section{$\left[1-\mathrm{C}_{6} \mathrm{H}_{8}\right]\left[\mathrm{BAr}_{4}^{\mathrm{F}}\right]$}

Crystals of this material undergo a phase change upon slow cooling to $100 \mathrm{~K}$. For this reason, the presented data was measured at $250 \mathrm{~K}$. 


\section{$\left[1-\mathrm{C}_{6} \mathrm{H}_{12}\right]\left[\mathrm{BAr}_{4}{ }_{4}\right]$}

In reply to $B$-Level Alert [PLAT088_ALERT_3_B]: The single-crystal to single-crystal transformation caused a loss in data quality. Because of this, the data/parameter ratio is acceptable.

In reply to B-Level Alert [PLAT971_ALERT_2_B and [PLAT972_ALERT_2_B]: The origin of this residual electron density relates to a positional disorder affecting the $\mathrm{Rh}$ metal centre. This is too small contribution to be satisfactorily modelled. As such it was deemed better to retain this electron density with a low $\mathrm{R}$-factor.

In reply to CB-Level Alert [PLAT971_ALERT_2_C] and [PLAT972_ALERT_2_C]: The origin of this residual electron density relates to a positional disorder affecting the Rh metal centre. This is too small contribution to be satisfactorily modelled. As such it was deemed better to retain this electron density with a low $R$-factor. 


\begin{tabular}{|c|c|c|c|c|c|}
\hline & {$\left[1-\mathrm{C}_{4} \mathrm{H}_{8}\right]\left[\mathrm{BAr} \mathrm{F}_{4}\right]$} & {$\left[1-\mathrm{C}_{4} \mathrm{H}_{10}\right]\left[\mathrm{BAr} \mathrm{Fr}_{4}\right]$} & {$\left[1-\mathrm{C}_{4} \mathrm{H}_{8}\right]\left[\mathrm{BAr}{ }_{4}^{\mathrm{F}}\right]^{*}$} & {$\left[1-\mathrm{C}_{6} \mathrm{H}_{8}\right]\left[\mathrm{BAr}_{4} \mathrm{~F}_{4}\right]$} & {$\left[1-\mathrm{C}_{6} \mathrm{H}_{12}\right]\left[\mathrm{BAr}_{4}^{\mathrm{F}}\right]$} \\
\hline Chemical formula & $\mathrm{C}_{62} \mathrm{H}_{68} \mathrm{BF}_{24} \mathrm{P}_{2} \mathrm{Rh}$ & $\mathrm{C}_{62} \mathrm{H}_{70} \mathrm{BF}_{24} \mathrm{P}_{2} \mathrm{Rh}$ & $\mathrm{C}_{62} \mathrm{H}_{68} \mathrm{BF}_{24} \mathrm{P}_{2} \mathrm{Rh}$ & $\mathrm{C}_{64} \mathrm{H}_{68} \mathrm{BF}_{24} \mathrm{P}_{2} \mathrm{Rh}$ & $\mathrm{C}_{64} \mathrm{H}_{72} \mathrm{BF}_{24} \mathrm{P}_{2} \mathrm{Rh}$ \\
\hline Formula weight & 1444.82 & 1446.84 & 1444.82 & 1468.84 & 1472.87 \\
\hline Temperature (K) & 150 & 100 & 150 & 250 & 150 \\
\hline Crystal system & triclinic & monoclinic & triclinic & monoclinic & monoclinic \\
\hline Space group & $\mathrm{P}-1$ & $\mathrm{P} 2_{1} / \mathrm{n}$ & $\mathrm{P}-1$ & $\mathrm{C} 2 / \mathrm{c}$ & $\mathrm{C} 2 / \mathrm{c}$ \\
\hline$a(\AA)$ & $12.7477(3)$ & 19.1238(3) & $12.7582(16)$ & $19.2893(2)$ & $19.1736(8)$ \\
\hline$b(\AA ̊)$ & $13.0092(3)$ & $34.6204(5)$ & $12.9595(15)$ & $17.2828(1)$ & $17.6512(8)$ \\
\hline$c(\AA)$ & $19.8574(4)$ & $19.5735(3)$ & $19.8097(8)$ & $20.2622(1)$ & 19.7601(12) \\
\hline$\alpha(\mathrm{deg})$ & $92.3462(17)$ & 90 & $92.028(6)$ & 90 & 90 \\
\hline$\beta(\operatorname{deg})$ & $90.9972(16)$ & $90.624(2)$ & $90.685(7)$ & $91.1490(1)$ & $91.086(5)$ \\
\hline$V(\operatorname{deg})$ & $96.6033(17)$ & 90 & $96.2300(10)$ & 90 & 90 \\
\hline$V\left(\AA^{3}\right)$ & $3267.70(13)$ & 12958.3(3) & $3253.5(6)$ & $6753.52(9)$ & $6686.3(6)$ \\
\hline$z$ & 2 & 8 & 2 & 4 & 4 \\
\hline$\rho$ (calcd) $\left(\mathrm{g} \mathrm{cm}^{-3}\right)$ & 1.468 & 1.483 & 1.475 & 1.445 & 1.463 \\
\hline$\mu\left(\mathrm{mm}^{-1}\right)$ & 3.530 & 3.561 & 3.545 & 3.426 & 3.461 \\
\hline Reflections collected & 77320 & 160559 & 11700 & 32330 & 36704 \\
\hline Unique reflections & 12411 & 24598 & 11700 & 6335 & 6351 \\
\hline $\begin{array}{l}\text { Restraints } \\
\text { Parameters }\end{array}$ & $791 / 1014$ & $1706 / 1939$ & $1171 / 1029$ & 192/555 & $2524 / 806$ \\
\hline$R_{\text {int }}$ & 0.0406 & 0.0943 & 0.0555 & 0.0349 & 0.0563 \\
\hline$R_{1}[I>2 \sigma(I)]$ & 0.0511 & 0.0949 & 0.1095 & 0.0548 & 0.1031 \\
\hline$w R_{2}$ [all data] & 0.1509 & 0.2543 & 0.2956 & 0.1709 & 0.2141 \\
\hline GooF & 1.096 & 1.059 & 1.139 & 1.098 & 1.082 \\
\hline $\begin{array}{l}\text { Residual electron } \\
\text { density }\left(\mathrm{e} \AA^{-3}\right)\end{array}$ & 2.38/-1.12 & $3.42 /-1.76$ & $1.99 /-1.41$ & $0.97 /-0.44$ & $3.45 /-2.31$ \\
\hline CCDC no. & 1916756 & 1916755 & $N / A$ & 1916748 & 1916750 \\
\hline
\end{tabular}

Table S1: Selected crystallographic and refinement data. * is from the dehydrogenation of [1- $\left.\mathbf{C}_{4} \mathrm{H}_{10}\right]\left[\mathrm{BAr}_{4}\right]$, see section S.4.1.3. 


\section{S.5.3. Single Crystal X-ray Diffraction Images}

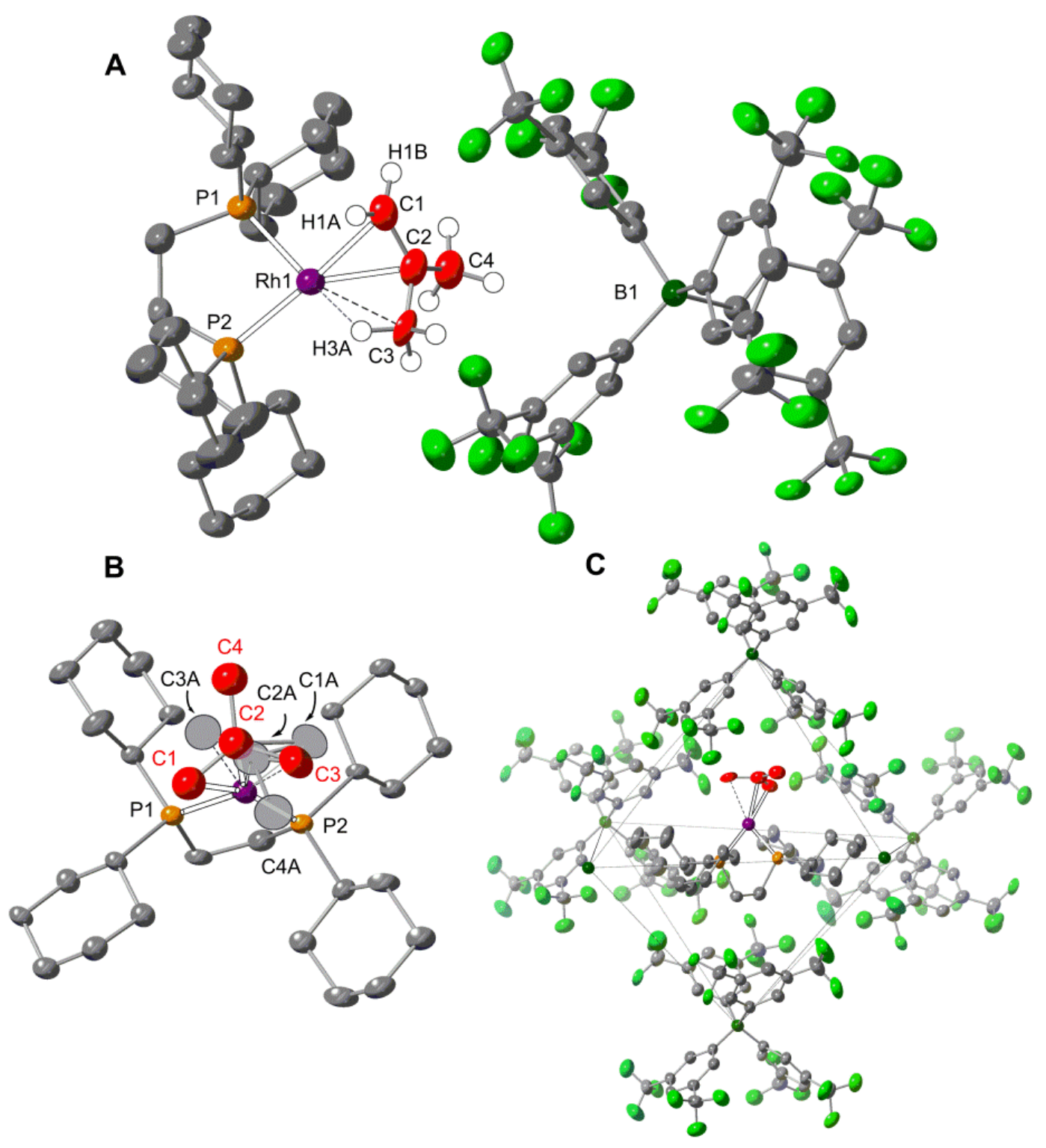

Figure S93: (A) Molecular structure of [1- $\left.\mathrm{C}_{4} \mathrm{H}_{8}\right]\left[B \mathrm{Br}^{\mathrm{F}}\right.$ ]. (B) Cationic fragment of [1$\left.\mathrm{C}_{4} \mathrm{H}_{8}\right]\left[\mathrm{BAr}_{4}{ }_{4}\right]$ showing major disorder components, where the ratio of disorder components is $0.71: 0.29$ for major: minor. (C) Structure displaying $\mathrm{O}_{h}$ anion network of the $\left[\mathrm{BAr}_{4}\right]^{-}$ion, with cationic fragment sat within the cavity; $-\left(\mathrm{Ar}_{4}{ }_{4}\right)$ removed from 2 boron atoms for clarity. Thermal ellipsoids set at $30 \%$ and hydrogen from phosphine ligand and $\left[\mathrm{BAr}_{4}{ }_{4}\right]^{-}$anion removed for clarity in all parts.

Selected bond lengths (Å): Rh1-P1 2.2238(9), Rh1-P2 2.2400(9), Rh1-C1 2.262(6), Rh1-C2 2.136(8), Rh1-C3 2.368(9), Rh1-H3A 1.848, C1-C2 1.320(12), C2-C3 1.474(13), C2-C4 1.513(13). 

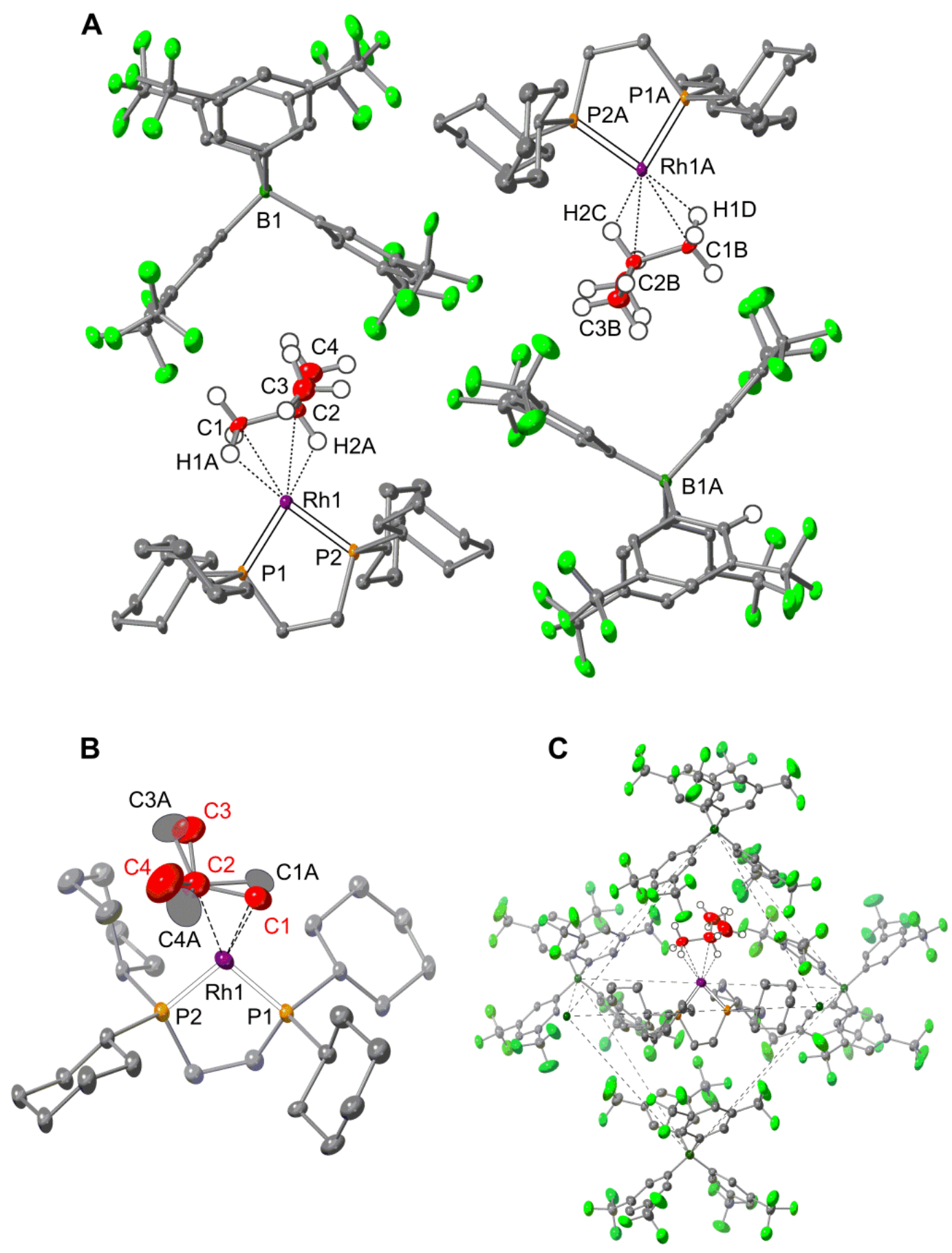

Figure S94: (A) Molecular structure of $\left[1-\mathrm{C}_{4} \mathrm{H}_{10}\right]\left[B \mathrm{Br}^{\mathrm{F}}{ }_{4}\right]$, showing only the major disorder components for both independent molecules in the asymmetric unit cell.

(B) Cationic fragment of the first molecule of [1-C $\left.\mathbf{C}_{4} \mathbf{H}_{10}\right]\left[B \mathrm{Ar}_{4}{ }_{4}\right]$ in the asymmetric cell, showing both disorder components (0.67: 0.33 for major (CX) and minor (CXA). No disorder is present on $\mathrm{C} 2$, and is shared between the two disorder components. Not shown is the disorder in the second molecule in the asymmetric unit, however is 
visually indistinguishable from that shown in (B). The disorder ratio for the second molecule is 0.56 : 0.44 for major: minor.

(C) Structure displaying $\mathrm{O}_{h}$ anion network of the $\left[\mathrm{BAr}_{4}\right]^{-}$ion, with cationic fragment sat within the cavity. $-\left(\mathrm{Ar}_{4}{ }_{4}\right)$ removed from 2 boron atoms for clarity. Thermal ellipsoids set at $30 \%$ and hydrogen from phosphine ligand and $\left[\mathrm{BAr}_{4}\right]^{-}$anion removed for clarity in all parts.

Selected bond lengths for the $1^{\text {st }}$ molecule $(\AA)$ : Rh1-P1 2.1830(14), Rh1-P2 2.1914(14), Rh1-C1 2.362(14), Rh1-H1A 1.920, Rh1-C2 2.442(7), Rh1-H2A 1.8055, C1-C2 1.551(13), C2-C3 1.528(13), C2-C4 1.516(13).

Selected bond lengths for the $2^{\text {nd }}$ molecule $(\AA)$ : Rh1A-P1A 2.1841(14), Rh1A-P2A 2.1887(15), Rh1A-C1B 2.390(14), Rh1A-H1D 1.980, Rh1A-C2A 2.438(8), Rh1AH2C 1.7978, C1B-C2B 1.544(16), C2B-C3B 1.500(19). 

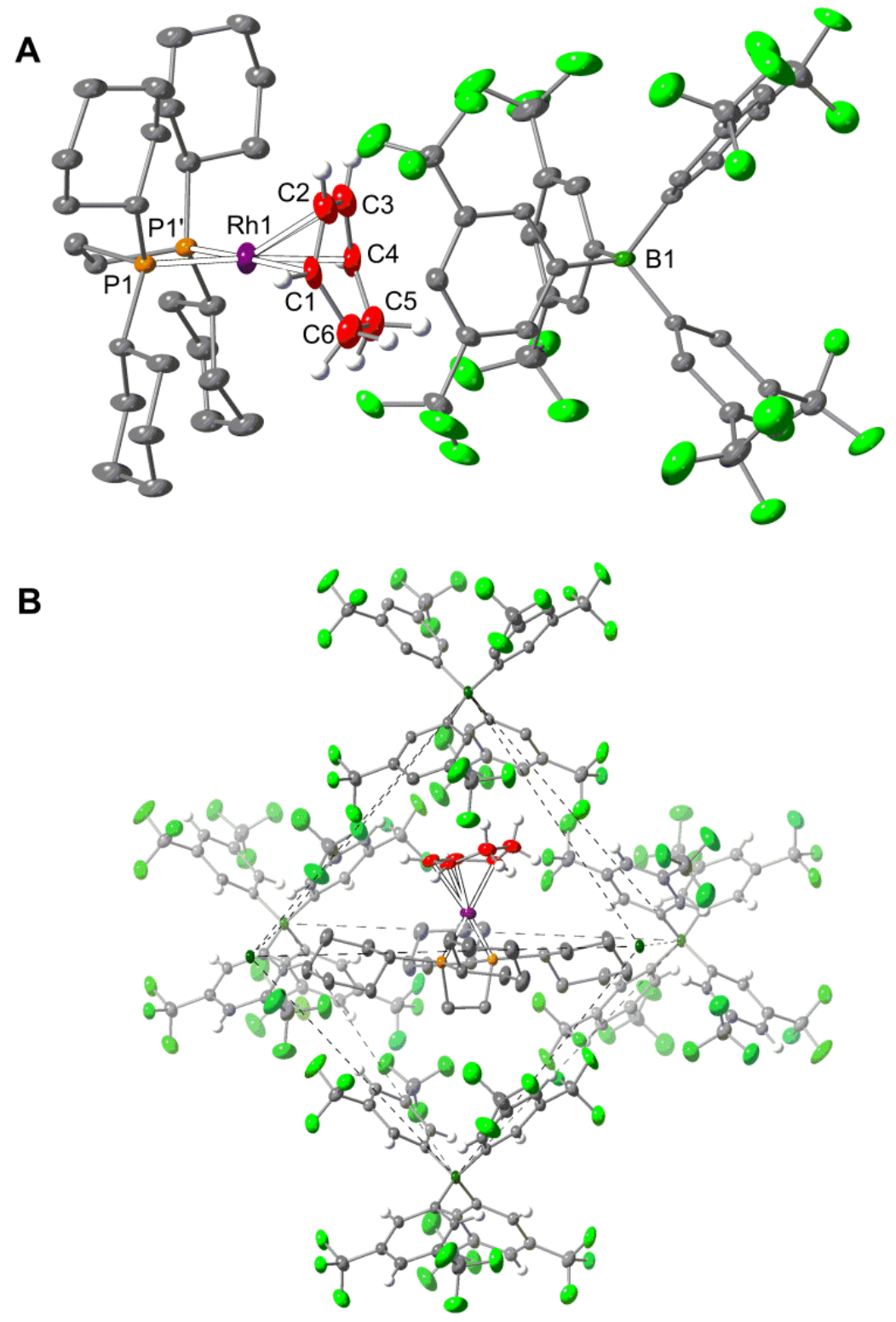

Figure S95: (A) Molecular structure of $\left[1-\mathrm{C}_{6} \mathrm{H}_{8}\right]\left[\mathrm{BAr}_{4}\right]$ displaying major disorder component only. Operation used to generate symmetry related atoms (P1 \& P1') 1 $\mathrm{x}, \mathrm{y}, 1 / 2-\mathrm{z}$. (B) Structure displaying $\mathrm{O}_{h}$ anion network of the $\left[\mathrm{BAr}_{4}\right]^{-}$ion, with cationic fragment sat within the cavity. $-\left(\operatorname{Ar}_{4}{ }_{4}\right)$ removed from 2 boron atoms for clarity. Thermal ellipsoids set at $30 \%$ and hydrogens from phosphine ligand and $\left[\mathrm{BAr}_{4}\right]^{-}$ anion removed for clarity in all parts.

Selected bond lengths (Å): Rh1-P1 2.2715(8), Rh1-P1' 2.2715(8), Rh1-C1 2.20(2), Rh1-C2 2.270(9), Rh1-C3 2.284(9), Rh1-C4 2.277(10), C1-C2 1.37(3), C2-C3 1.499(18), C3-C4 1.35(3), C4-C5 1.50(3), C5-C6 1.397(19), C6-C1 1.57(3). 
A

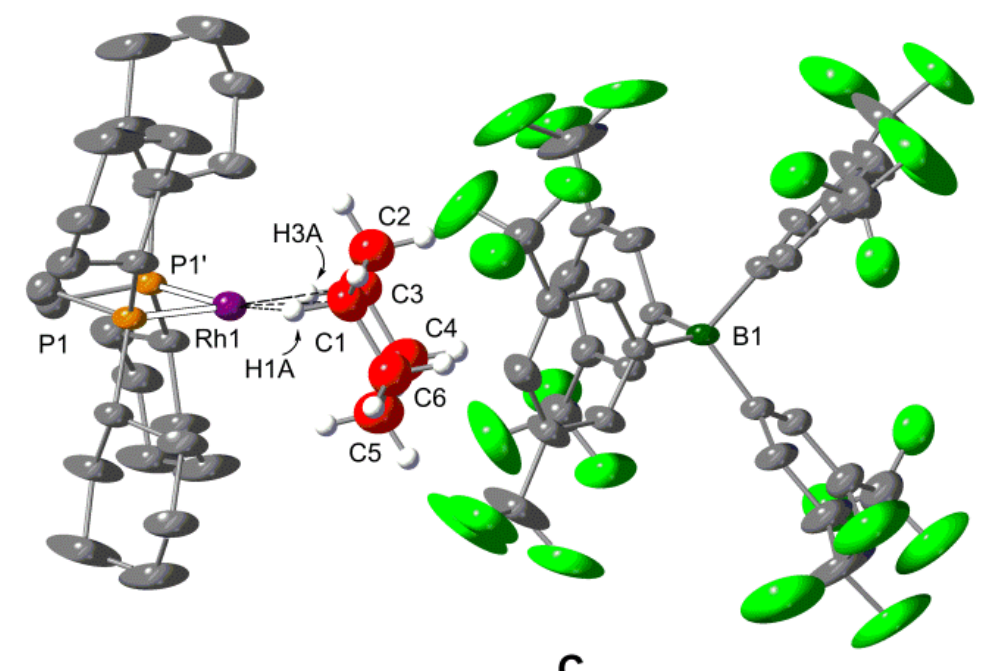

B

C
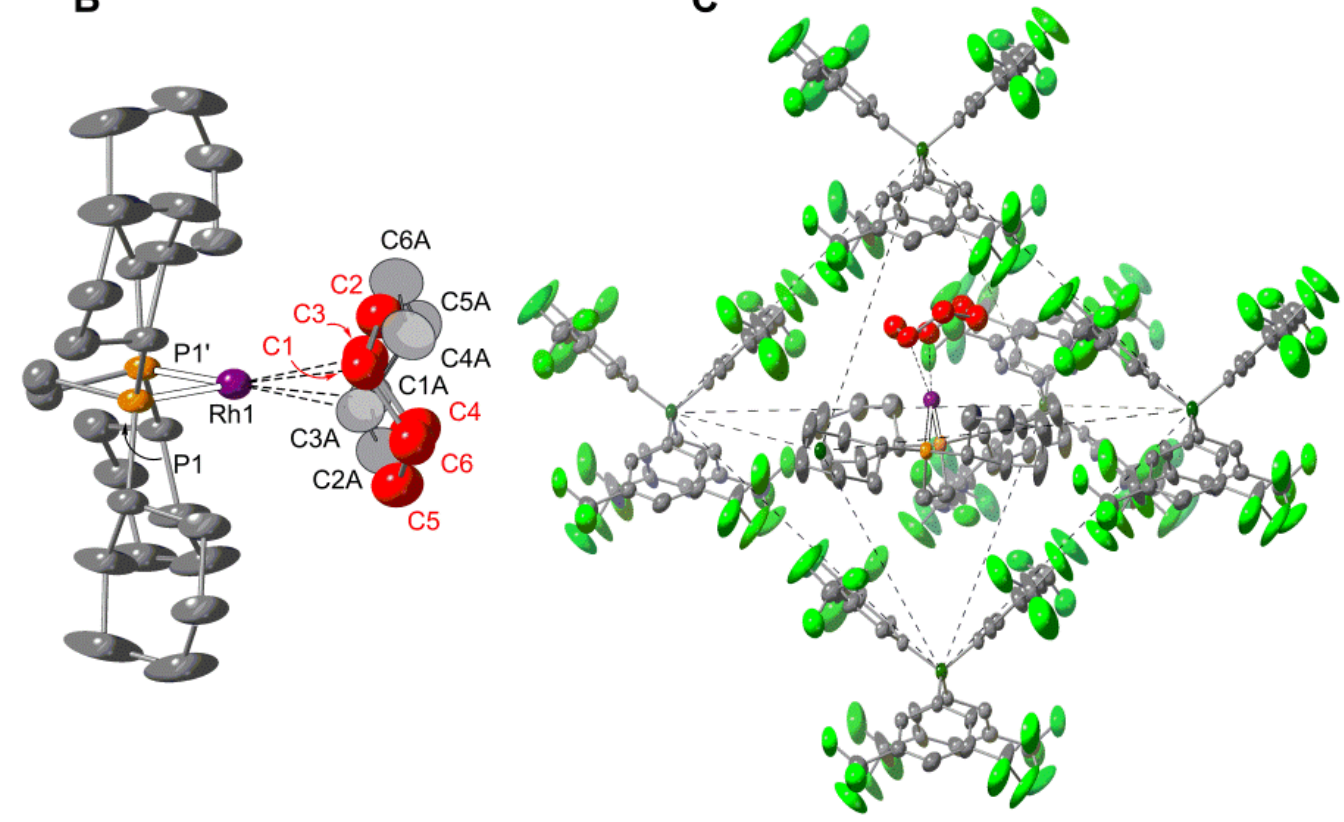

Figure S96: (A) Molecular structure of [1- $\left.\mathrm{C}_{6} \mathrm{H}_{12}\right]\left[B A r^{\mathrm{F}}\right]$. (B) Cationic fragment of [1$\left.\mathrm{C}_{6} \mathrm{H}_{12}\right]\left[\mathrm{BAr}_{4}{ }_{4}\right.$ ] showing major disorder components $(50 \%)$. Operation used to generate symmetry related atoms (P1 \& P1') 1-x,y,1/2-z. (B) Structure displaying $\mathrm{O}_{h}$ anion network of the $\left[\mathrm{BAr}_{4}\right]^{-}$ion, with cationic fragment sat within the cavity. $-\left(\mathrm{Ar}_{4}\right)$ removed from 1 boron atoms for clarity. Thermal ellipsoids set at $30 \%$ and hydrogens from phosphine ligand and $\left[\mathrm{BAr}_{4}\right]^{-}$anion removed for clarity in all parts.

Selected bond lengths (Å): Rh1-P1 2.191(2), Rh1-P1' 2.191(2), Rh1-C1 2.62(2), Rh1-H1A 1.9065, Rh1-C3 2.53(2), Rh1-H3A 1.7777, C1-C2 1.529(15), C2-C3 1.531(15), C3-C4 1.517(15), C4-C5 1.516(16), C5-C6 1.510(15), C6-C1 1.510(15). 


\section{S.6. Computational Methods}

\section{S.6.1. Solid-State Calculations}

All static Kohn-Sham DFT calculations were performed on periodic models of the studied rhodium complexes, employing the Gaussian Plane Wave (GPW) formalism as implemented in the QUICKSTEP ${ }^{\mathrm{S16}}$ module within the CP2K program suite (Version 5.0). ${ }^{S 17}$ Molecularly optimized basis sets of double- $\zeta$ quality plus polarization in their short-range variant (DZVP-MOLOPT-SR-GTH) ${ }^{518}$ were used on all atomic species. The interaction between the core electrons and the valence shell (Rh: 17, B: 3, C: 4, P: 5, F: 7, H: 1 electrons) was described by Goedecker-TeterHutter (GTH) pseudo potentials. ${ }^{519-21}$ The generalized gradient approximation (GGA) to the exchange-correlation functional according to Perdew-Burke-Ernzerhof $(\mathrm{PBE})^{\mathrm{S} 22}$ was used in combination with Grimme's D3-correction for dispersion interactions. ${ }^{\text {S23 }}$ The auxiliary plane wave basis set was truncated at a cutoff of 500 Ry. The maximum force convergence criterion was set to $10^{-4} \mathrm{Eh} \cdot \mathrm{Bohr}^{-1}$, whilst default values were used for the remaining criteria. The convergence criterion for the self-consistent field (SCF) accuracy was set to $10^{-7}$ Eh and $10^{-8}$ Eh for geometry optimizations and vibrational analysis, respectively.

The Brillouin zone was sampled using the $\Gamma$-point. Initial coordinates for [1-

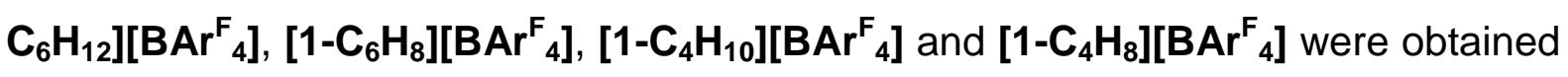
from the experimental crystallographic data, with the hydrogen positions normalised where possible with Mercury. ${ }^{550}$ Periodic boundary conditions (PBC) were applied throughout in combination with fixed unit cell parameters obtained from experiment. All geometries were first partially relaxed, keeping the heavy atoms (non-H, F) fixed, then fully relaxed without imposing any constraints, whilst keeping unit cell parameters constant in both cases. $\left[1-\mathbf{C}_{6} \mathbf{H}_{12}\right]\left[\mathrm{BAr}_{4}{ }_{4}\right]$ displays two crystallographically equivalent components. For [1- $\left.\mathbf{C}_{4} \mathrm{H}_{10}\right]\left[\mathrm{BAr}{ }_{4}\right]$ two inequivalent disordered components are observed and all calculations were performed on the major component. Both independent cations were assessed in electronic structure and NMR calculations and gave similar results.

The structure of $\left[1-\mathrm{C}_{6} \mathrm{H}_{10}\right]\left[\mathrm{BAr}{ }_{4}\right]$ was constructed by removing appropriate hydrogen atoms from the experimental structure of $\left[1-\mathbf{C}_{6} \mathbf{H}_{12}\right]\left[B \mathbf{B r}_{4}\right]$ under the constraint of retaining the crystal symmetry and fully optimising the remaining atomic 
positions. This generated two possible structures depending on which $\mathrm{C}-\mathrm{C}$ bond was dehydrogenated and the more stable form was used in the main paper.

For reactivity studies different reaction pathways were initially explored using an isolated rhodium molecular cation model with the Gaussian suite of programs (see details below). Transition states located in this way provided the basis for transition state searches in the solid state, with pre-optimisations in the solid state run by fixing the key reacting atoms at one of the Rh-centres. A partial vibrational analysis was then used to identify the corresponding imaginary mode. This pre-optimized TS structure was then refined using the dimer method ${ }^{\mathrm{S} 24}$ with the tighter convergence criteria detailed above. For challenging fluxional processes the climbing image nudged elastic band (CI-NEB) method, ${ }^{\text {S25 }}$ using 8 or 12 images, was used to obtain candidate transition states that were then optimised using the dimer method as above. All optimized stationary points were characterized by analysis of their numerical second derivatives with a displacement of 0.01 Bohr. Minima and transition states have no or exactly one imaginary eigenvalue, respectively. All transition states were further analysed using an "IRC-like" approach, whereby transition state geometries were displaced along the negative mode in both directions and then fully optimising the two resulting structures. Further details on this protocol have been reported elsewhere. ${ }^{\text {S26 }}$ A spurious imaginary frequency $(i=6$ $\mathrm{cm}^{-1}$ ) was found in one of the stationary points (IX), which appears to be due to numerical inaccuracies in the vibrational analysis, which is a familiar issue in these type of calculations. ${ }^{\text {S27-28 }}$

Gibbs free energies for structures computed in the solid state were calculated using the TAMkin software toolkit. ${ }^{\text {S29 }}$

All computed structures are available as a separate file of Cartesian coordinates.

\section{S.6.2. Molecular Calculations}

Molecular calculations employed the GAUSSIAN 09 (revision D.01) program package $^{\mathrm{S} 30}$ and employed the BP86 GGA functional. ${ }^{\text {S31-32 }}$ Stuttgart-Dresden $(S D D)^{S 33}$ relativistic effective core potentials $(E C P)$ in combination with the associated basis sets were utilized to describe $R$ h and $P$, with polarization functions added for $P(\zeta=0.387)$. ${ }^{\mathrm{S} 34}$ The $6-31 \mathrm{G}(\mathrm{d}, \mathrm{p})$ basis sets ${ }^{\mathrm{S35}-36}$ were used on remaining atoms. 
Electronic structure analyses were performed on the geometries of the $\mathrm{Rh}$ cations extracted from the CP2K-optimised structures with the heavy atoms fixed at the experimental positions. An electron density file suitable for further analysis was generated from a single-point calculation.

The topology of the electron density was analysed by means of QTAIM (Quantum

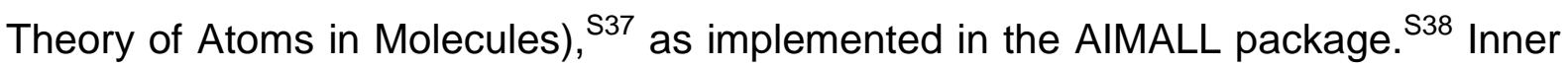
shell electrons on $\mathrm{Rh}$ and $\mathrm{P}$ modelled by ECPs were represented by core density functions (extended wavefunction format).

NBO calculations were performed using the NBO 6.0 program $^{\mathrm{S} 39}$, using the same geometries as for the QTAIM calculations above.

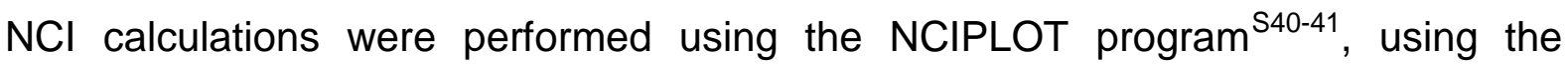
nearest neighbour ion-pair molecular structures extracted from CP2K optimised geometries. The promolecular electron density was employed.

Orbital plots were created with Chemcraft ${ }^{\mathrm{S} 2}$ with an outer contour value of 0.0625 .

\section{S.6.3. NMR Calculations}

Isotropic ${ }^{13} \mathrm{C}$ and ${ }^{1} \mathrm{H}$ magnetic shielding constants $\left(\sigma_{\text {iso }}\right)$ were generated using the GIPAW method ${ }^{\mathrm{S} 43-44}$ as implemented in CASTEP 17.21 . $^{\mathrm{S} 45}$ For $\left[\mathbf{1}-\mathbf{C}_{\mathbf{6}} \mathbf{H}_{\mathbf{1 2}}\right] \mathbf{B B A r}_{\mathbf{4}}$ ] three approaches were assessed: Model 1 based on the fully optimised geometry in the solid-state; Model 2 based on the experimental structure with only the positions of $\mathrm{H}$ and $\mathrm{F}$ atoms being optimised and; an ion-pair model based on the nearest neighbour ion-pair extracted form the fully optimised geometry used in Model 1. Use of the ion-pair model gave comparable results. For [1- $\left.\mathbf{C}_{4} \mathbf{H}_{10}\right]\left[\mathrm{BAr}_{4}{ }_{4}\right]$ the size of the unit cell precluded calculations on the full unit cell and so the ion-pair model was adopted. The plane wave basis set was truncated at $80 \mathrm{Ry}$, while the Brillouin zone was sampled using a Monkhorst-Pack grid ${ }^{S 46}$ with a k-point spacing of $0.04 \AA^{-1}$. These settings were shown to yield converged NMR parameters on related systems. $^{\text {S26 }}$ The single-point calculations were performed using the PBE GGA functional, ${ }^{\text {S22 }}$ using Ultra-soft pseudopotentials generated on-the-fly to represent the core electron shells. Scalar-relativistic effects were incorporated through the zerothorder regular approximation (ZORA). ${ }^{\text {S47-48 }}$ The ultrafine SCF convergence threshold of $10^{-8} \mathrm{eV}$ atom ${ }^{-1}$ was used throughout. Computed ${ }^{13} \mathrm{C}$ isotropic shielding constants were then converted into chemical shift values $(\delta)$ using the linear regression fit $^{\mathrm{S49}}$ 
from the previously studied pentane system. ${ }^{\text {S26 }}$ As previously relative isotropic proton $\left({ }^{1} \mathrm{H}\right)$ chemical shifts were obtained by referencing computed shielding constants against those of the standard tetramethylsilane (TMS) according to $\delta$ iso $\left({ }^{1} \mathrm{H}\right)=$ $\sigma_{\text {ref }}\left(\right.$ TMS) - $\sigma_{\text {iso, }}$, where $\sigma_{\text {ref }}(T M S)$ was calculated as $\delta 31.15$ (cubic supercell with length $20 \AA$ ). ${ }^{\mathrm{S} 26}$ 


\section{S.7. Computed Reactions Profiles}

\section{S.7.1. Dehydrogenation of the Isolated $\left[1-\mathrm{C}_{6} \mathrm{H}_{12}\right]^{+}$Cation}

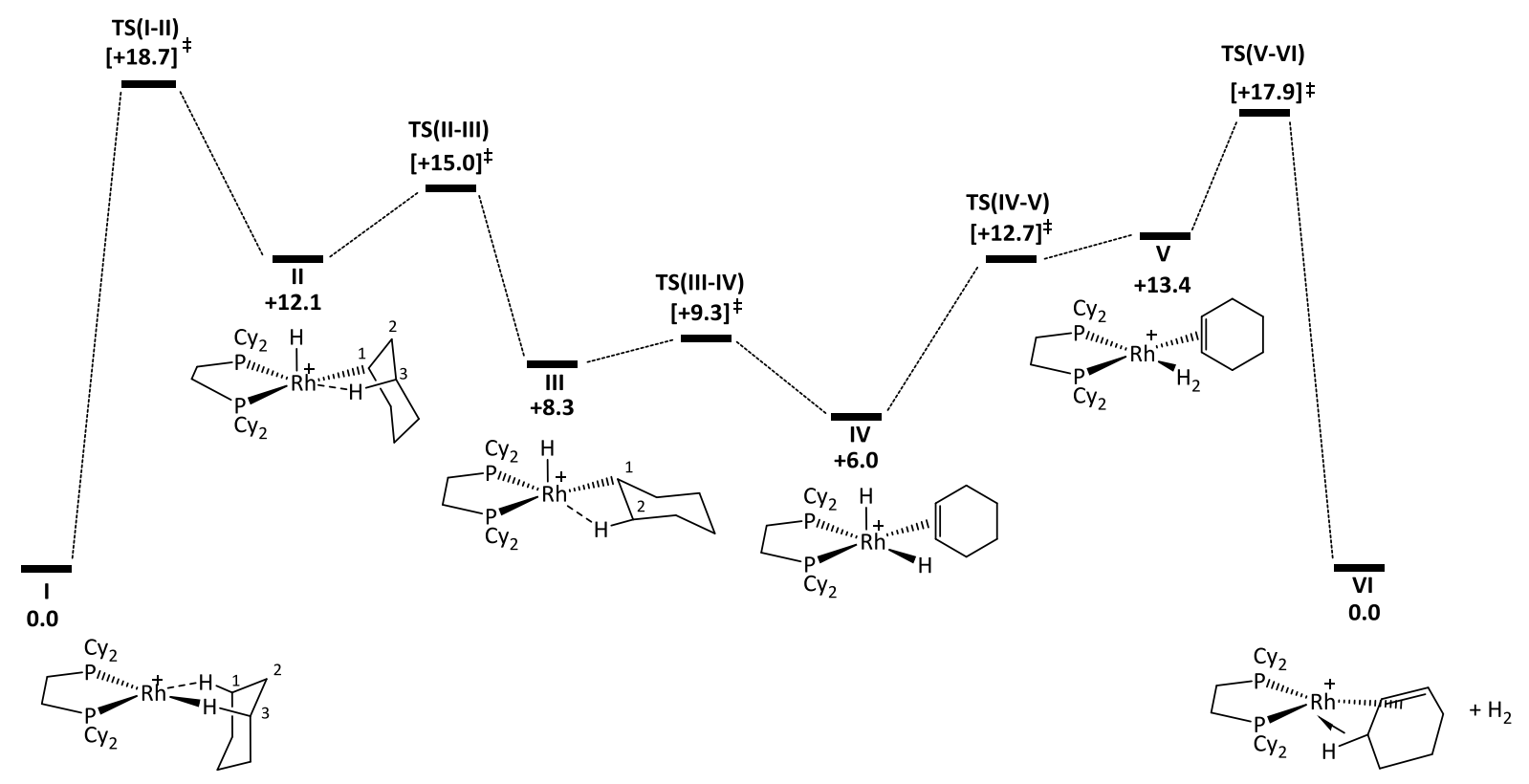

Figure S97: Computed free energy reaction profile $(\mathrm{kcal} / \mathrm{mol})$ for dehydrogenation of the isolated $\left[1-\mathrm{C}_{6} \mathrm{H}_{12}\right]^{+}$cation via initial oxidative cleavage of the $\mathrm{C}-\mathrm{H}^{1}$ bond.

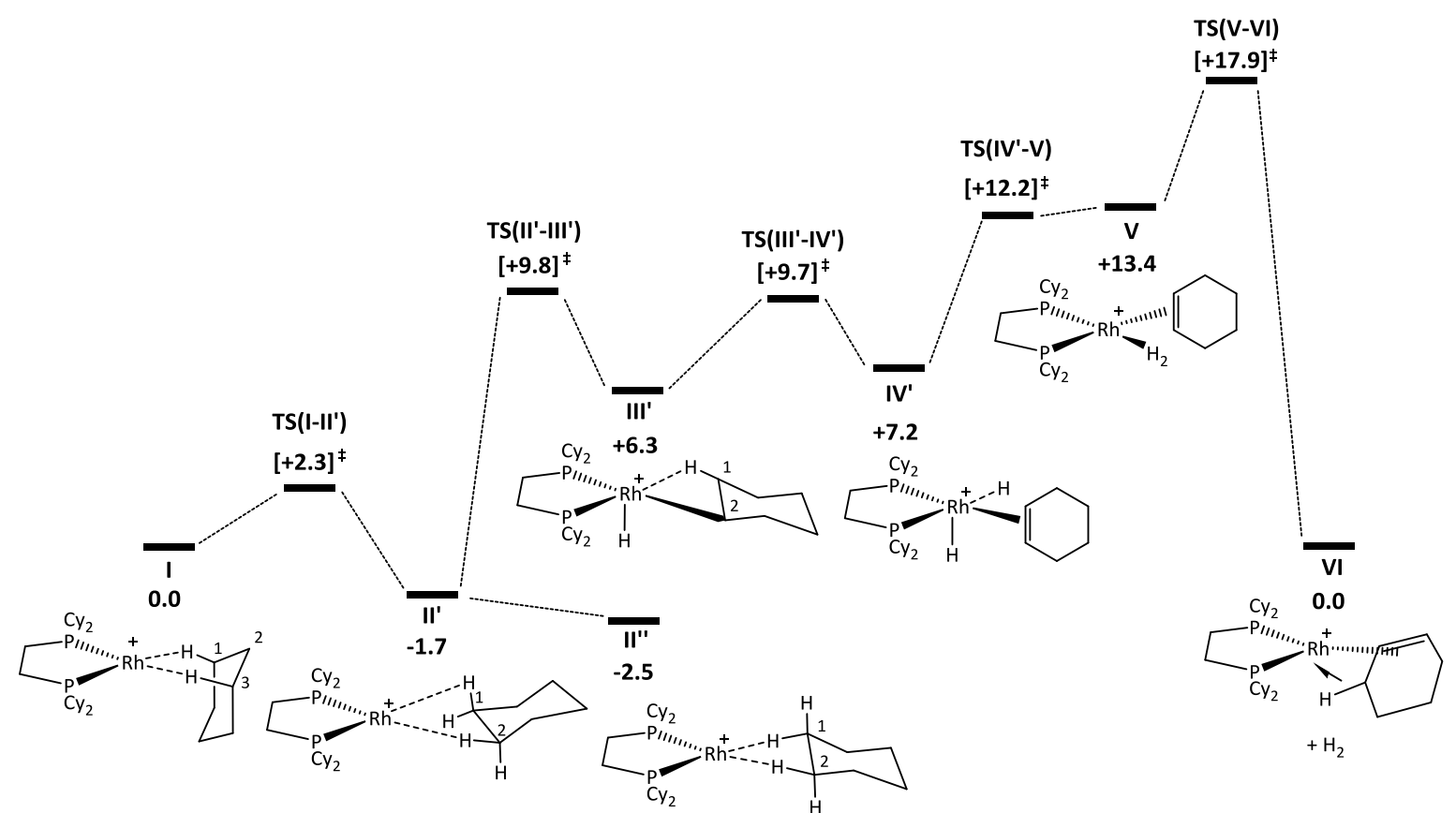

Figure S98: Computed free energy reaction profile $(\mathrm{kcal} / \mathrm{mol})$ for dehydrogenation of the isolated $\left[1-\mathbf{C}_{6} \mathbf{H}_{12}\right]^{+}$cation via an initial rearrangement to a 1,2 binding mode followed by oxidative cleavage of the $\mathrm{C}-\mathrm{H}^{2}$ bond. 


\begin{tabular}{lcc}
\hline Isolated Cation & $\begin{array}{c}\text { SCF Energy (a. } \\
\text { u.) }\end{array}$ & $\begin{array}{c}\text { Free Energy @ 298.15 K (a. } \\
\text { u.) }\end{array}$ \\
\hline I & -1379.280683 & -1378.505513 \\
TS (I - II) & -1379.248161 & -1378.475735 \\
II & -1379.259755 & -1378.486258 \\
TS (II - III) & -1379.255972 & -1378.481609 \\
III & -1379.265112 & -1378.492212 \\
TS (III - IV) & -1379.260011 & -1378.49068 \\
IV & -1379.267128 & -1378.495987 \\
TS (IV - V) & -1379.254042 & -1378.485205 \\
V & -1379.255114 & -1378.484236 \\
TS (V - VI) & -1379.245969 & -1378.477052 \\
VI & -1379.258177 & -1378.505514 \\
TS (I - II') & -1379.27733 & -1378.501771 \\
II' & -1379.28219 & -1378.508175 \\
II'” & -1379.283105 & -1378.509544 \\
TS (II' - III') & -1379.260945 & -1378.489911 \\
III' & -1379.266156 & -1378.495414 \\
TS (III' - IV') & -1379.259012 & -1378.490066 \\
IV' & -1379.264991 & -1378.493974 \\
TS (IV' - V) & -1379.254484 & -1378.486136 \\
\hline
\end{tabular}

Table S2: Computed energies of stationary points along the pathways shown in Figures S97 and S98.

\section{S.7.2. Dehydrogenation of the Isolated $\left[1-\mathrm{C}_{6} \mathrm{H}_{10}\right]^{+}$Cation}

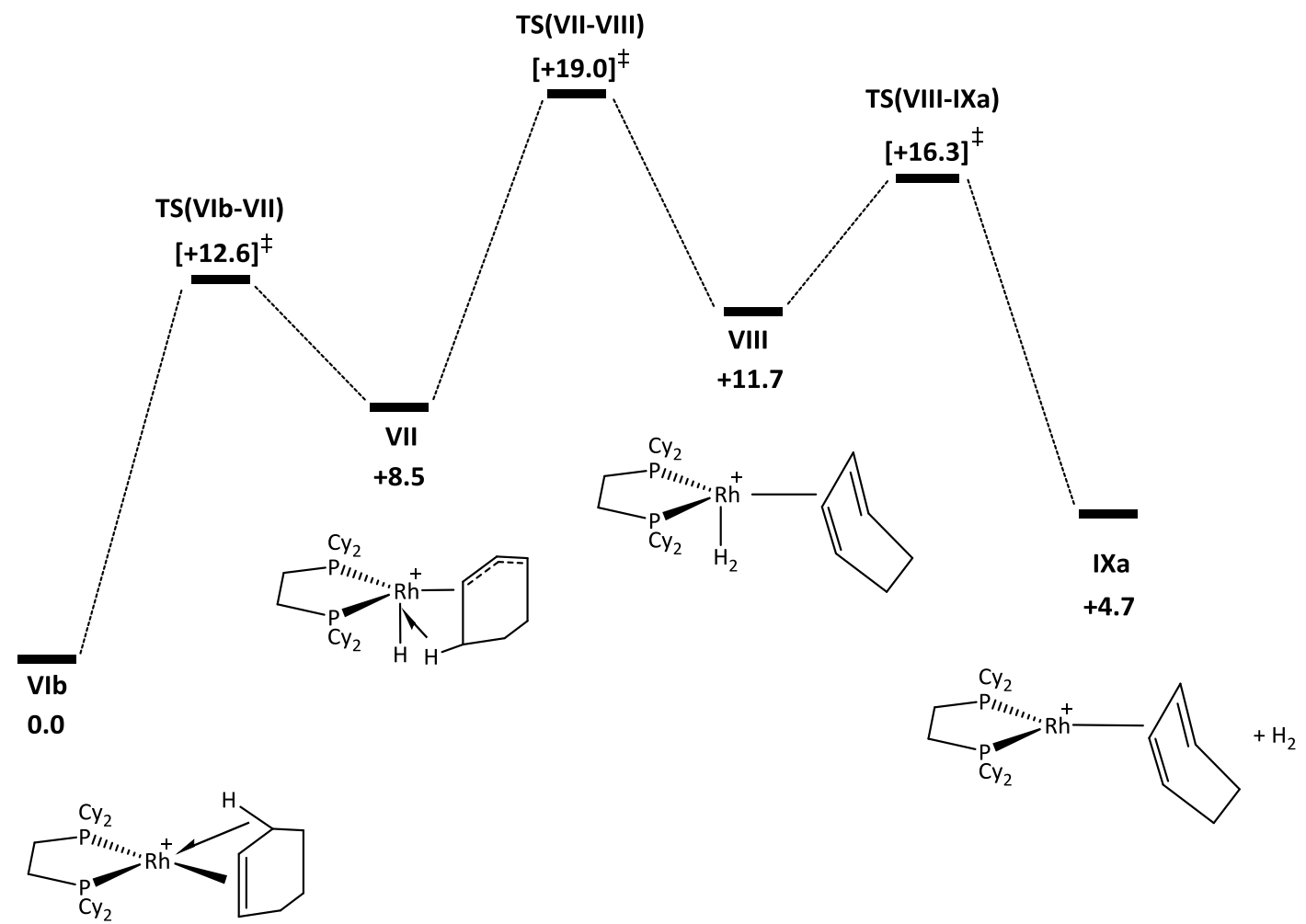

Figure S99: Computed free energy reaction profile $(\mathrm{kcal} / \mathrm{mol})$ for dehydrogenation of the isolated $\left[1-\mathrm{C}_{6} \mathrm{H}_{10}\right]^{+}$cation via initial oxidative cleavage to form an exo-allyl hydride intermediate. 


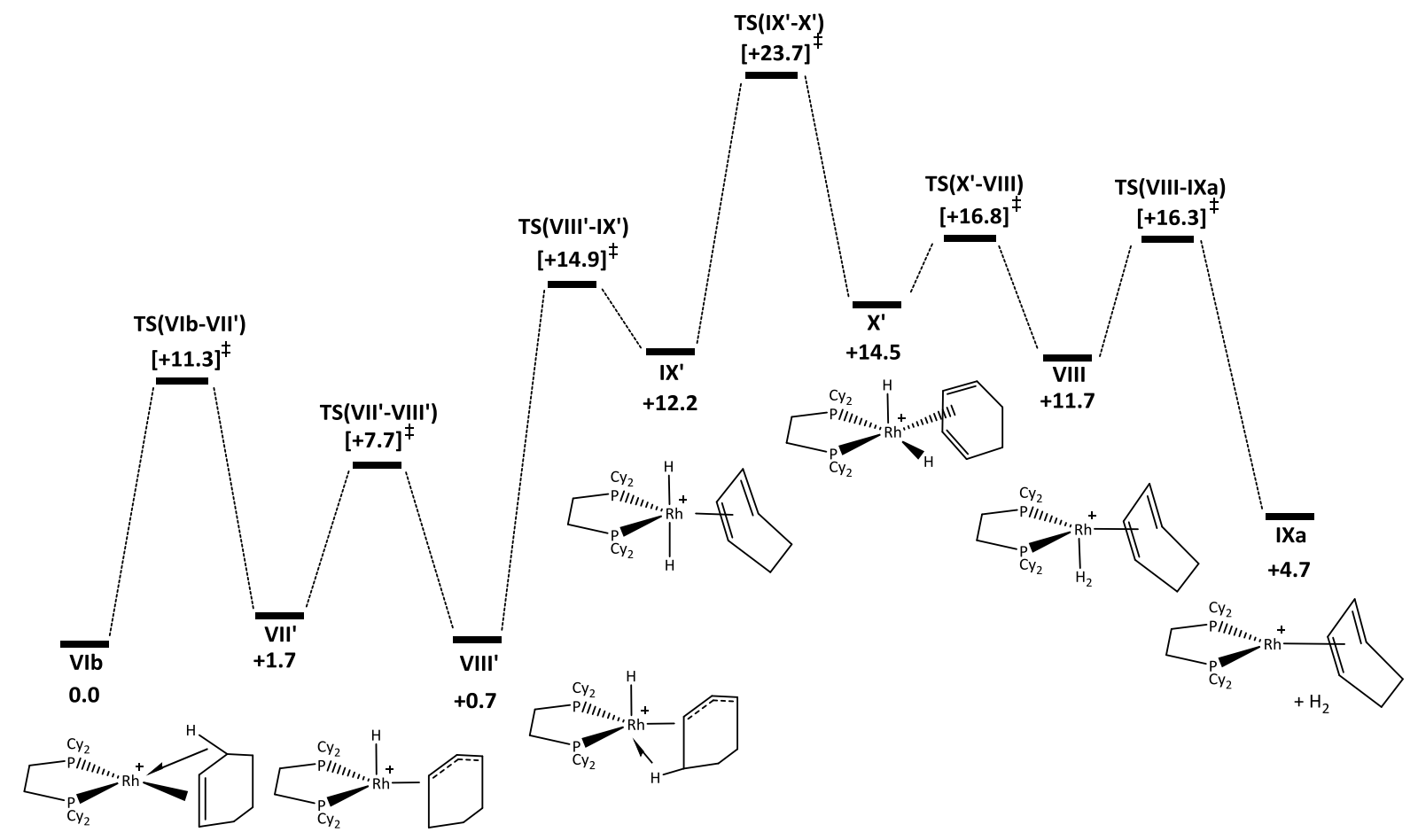

Figure S100: Computed free energy reaction profile $(\mathrm{kcal} / \mathrm{mol})$ for dehydrogenation of the isolated $\left[1-\mathrm{C}_{6} \mathrm{H}_{10}\right]^{+}$cation via initial oxidative cleavage of the agostic $\mathrm{C}-\mathrm{H}$ bond to form an endo-allyl hydride intermediate.

\begin{tabular}{|c|c|c|}
\hline Isolated Cation & $\begin{array}{l}\text { SCF Energy (a. } \\
\text { u.) }\end{array}$ & $\begin{array}{c}\text { Free Energy @ } 298.16 \text { K (a. } \\
\text { u.) }\end{array}$ \\
\hline VIb & -1378.081611 & -1377.327262 \\
\hline TS (VIb - VII) & -1378.0601 & -1377.307252 \\
\hline VII & -1378.067685 & -1377.313707 \\
\hline TS (VII - VIII) & -1378.047275 & -1377.296996 \\
\hline VIII & -1378.058924 & -1377.308609 \\
\hline TS (VIII - IXa) & -1378.048014 & -1377.301305 \\
\hline $\mathrm{IXa}$ & -1378.055202 & -1377.319806 \\
\hline TS (VIb - VII') & -1378.061473 & -1377.309208 \\
\hline VII' & -1378.077601 & -1377.324588 \\
\hline TS (VII' - VIII') & -1378.068109 & -1377.314998 \\
\hline VIII' & -1378.08005 & -1377.326224 \\
\hline TS (VIII' - IX') & -1378.05293 & -1377.303595 \\
\hline IX' & -1378.056535 & -1377.307883 \\
\hline TS (IX' - X') & -1378.038878 & -1377.289551 \\
\hline & -1378.055905 & -1377.304155 \\
\hline TS (X' - VIII) & -1378.0513 & -1377.300499 \\
\hline
\end{tabular}

Table S3: Computed energies of stationary points along the pathways shown in Figures $\mathrm{S} 99$ and $\mathrm{S} 100$. 


\section{S.7.3. Dehydrogenation of $\left[1-\mathrm{C}_{6} \mathrm{H}_{12}\right]\left[B \mathrm{Br}_{4}{ }_{4}\right]$ in the Solid-State}

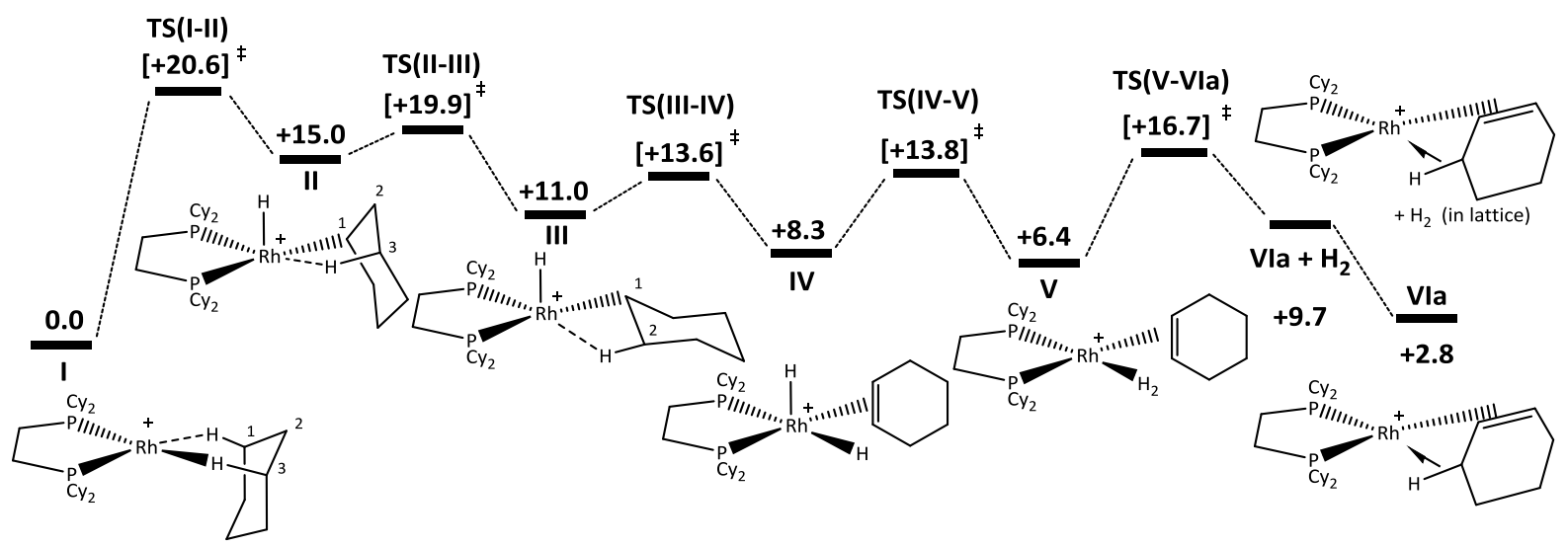

Figure S101: Computed free energy reaction profile $(\mathrm{kcal} / \mathrm{mol})$ for dehydrogenation of the $\left[1-\mathrm{C}_{6} \mathrm{H}_{12}\right]\left[\mathrm{BAr}{ }_{4}{ }_{4}\right]$, system via initial oxidative cleavage of the $\mathrm{C}-\mathrm{H}^{1}$ bond. Only the reacting $\mathrm{Rh}$ complex is shown with $\left[\mathrm{BAr}_{4}\right]^{-}$anions and spectator $\mathrm{Rh}$ cations omitted for clarity.

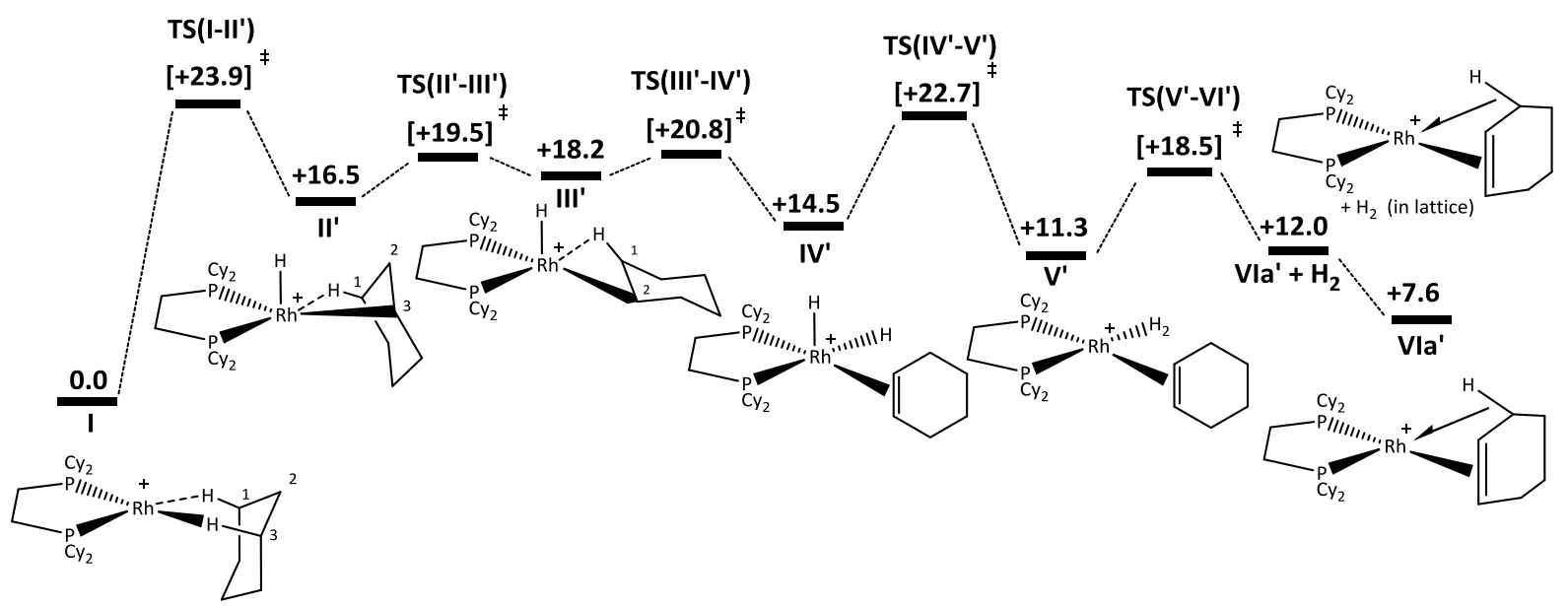

Figure S102: Computed free energy reaction profile $(\mathrm{kcal} / \mathrm{mol})$ for dehydrogenation of the [1- $\left.\mathrm{C}_{6} \mathrm{H}_{12}\right]\left[\mathrm{BAr}_{4}{ }_{4}\right]$, system via initial oxidative cleavage of the $\mathrm{C}-\mathrm{H}^{3}$ bond. Only the reacting $\mathrm{Rh}$ complex is shown with $\left[\mathrm{BAr}_{4}\right]^{-}$anions and spectator $\mathrm{Rh}$ cations omitted for clarity. 


\begin{tabular}{lcc}
\hline Solid State & $\begin{array}{c}\text { SCF Energy (a. } \\
\text { U.) }\end{array}$ & $\begin{array}{c}\text { SCF Energy Diff. (kcal / } \\
\text { mol) }\end{array}$ \\
\hline I & -4462.088766 & 0.0 \\
TS (I - II) & -4462.053131 & 22.3609 \\
II & -4462.063259 & 16.0057 \\
TS (II - III) & -4462.056574 & 20.2009 \\
III & -4462.061968 & 16.8156 \\
TS (III - IV) & -4462.055429 & 20.9190 \\
IV & -4462.065180 & 14.8002 \\
TS (IV - V) & -4462.053137 & 22.3571 \\
V & -4462.065450 & 14.6306 \\
TS (V - Vla) & -4462.044764 & 27.6116 \\
Vla + H & -4462.056994 & 19.9371 \\
Vla & -4460.891269 & 22.3211 \\
TS (I - II') & -4462.048997 & 24.9551 \\
II' & -4462.060729 & 17.5930 \\
TS (II' - III') & -4462.056793 & 20.0633 \\
III' & -4462.062665 & 16.3784 \\
TS (III' - IV') & -4462.055583 & 20.8225 \\
IV' & -4462.064813 & 15.0303 \\
TS (IV' - V') & -4462.051139 & 23.6108 \\
V') & -4462.064886 & 14.9847 \\
TS (V' - Vla') & -4462.049781 & 24.4632 \\
Vla' + H & -4462.056830 & 20.0397 \\
Vla' & -4460.891062 & 22.4514 \\
\hline
\end{tabular}

Table S4: Computed energies of stationary points along the pathways shown in Figures S101 and S102.

\section{S.7.4. Dehydrogenation of $\left[1-\mathrm{C}_{6} \mathrm{H}_{10}\right]\left[B \mathrm{Br}_{4}{ }_{4}\right]$ in the Solid-State}

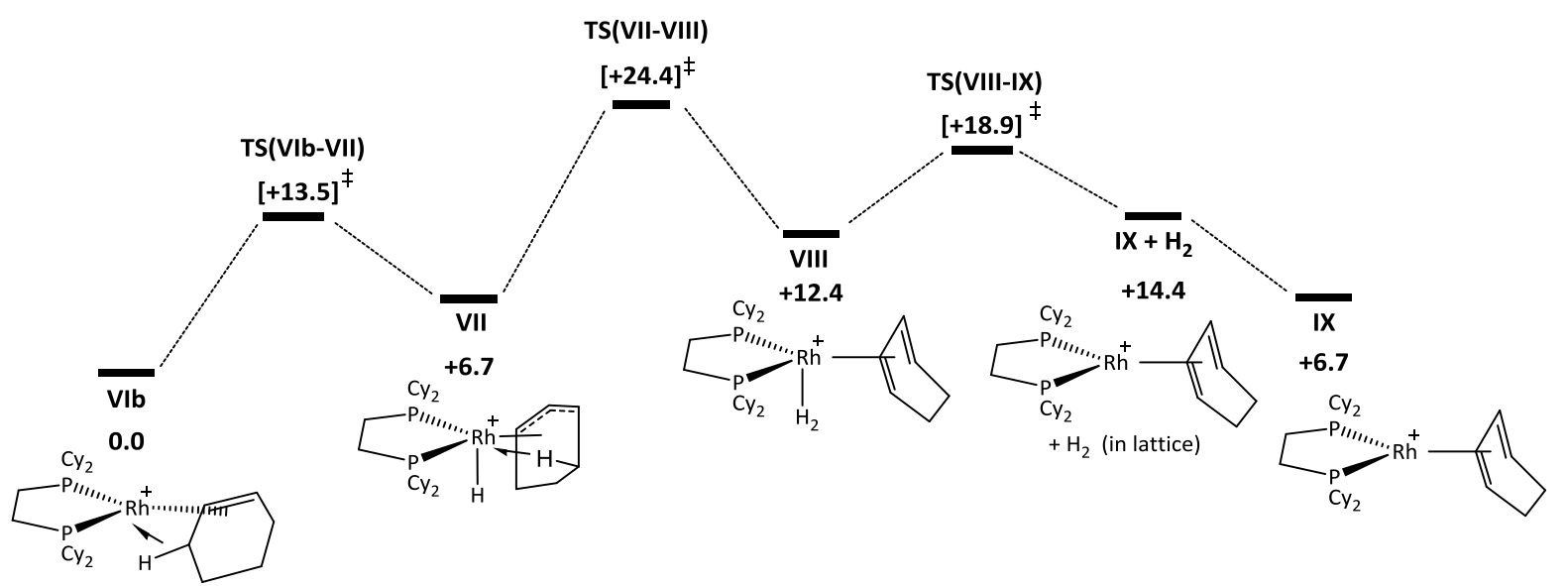

Figure S103: Computed free energy reaction profile $(\mathrm{kcal} / \mathrm{mol})$ for dehydrogenation of the [1- $\left.\mathrm{C}_{6} \mathrm{H}_{10}\right]\left[\mathrm{BAr}_{4}\right]$, system via initial oxidative cleavage of the left agostic $\mathrm{C}-\mathrm{H}$ bond, forming an exo-allyl hydride. Only the reacting Rh complex is shown with $\left[\mathrm{BAr}_{4}{ }_{4}^{-}\right.$anions and spectator Rh cations omitted for clarity. 


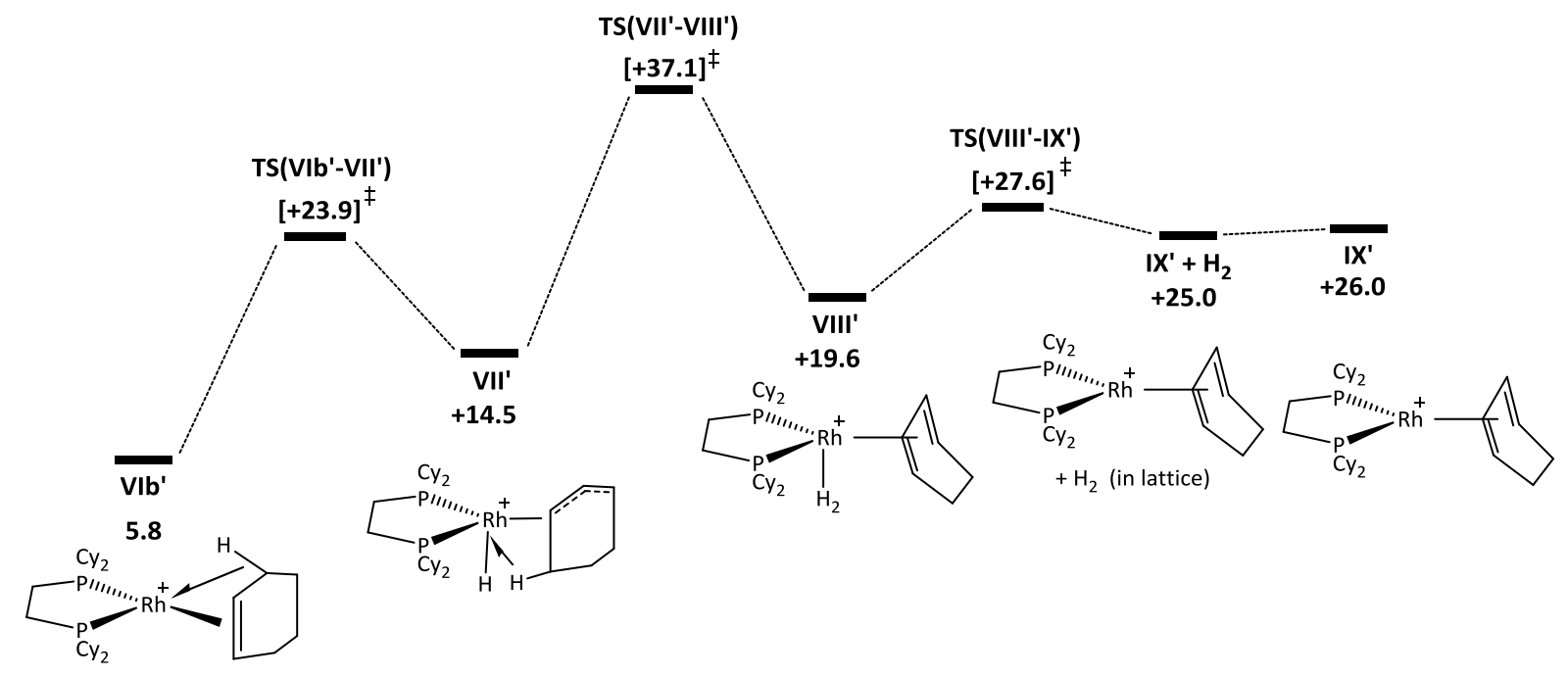

Figure S104: Computed SCF energy reaction profile $(\mathrm{kcal} / \mathrm{mol})$ for dehydrogenation of the [1- $\left.\mathrm{C}_{6} \mathrm{H}_{10}\right]\left[\mathrm{BAr}_{4}{ }_{4}\right]$, system via initial oxidative cleavage of the right agostic $\mathrm{C}-\mathrm{H}$ bond, forming an endo-allyl hydride. Only the reacting $\mathrm{Rh}$ complex is shown with $\left[\mathrm{BAr}_{4}{ }_{4}^{-}\right.$anions and spectator Rh cations omitted for clarity.

\begin{tabular}{lcc}
\hline Solid State & $\begin{array}{c}\text { SCF Energy (a. } \\
\text { U.) }\end{array}$ & $\begin{array}{c}\text { SCF Energy Diff. (kcal / } \\
\text { mol) }\end{array}$ \\
\hline VIb & -4457.310242 & 0.0 \\
TS (VIb - VII) & -4457.281984 & 17.7317 \\
VII & -4457.295942 & 8.9730 \\
TS (VII - VIII) & -4457.262857 & 29.7343 \\
VIII & -4457.284235 & 16.3195 \\
TS (VIII - IX) & -4457.270651 & 24.8434 \\
IX + H & -4457.275759 & 21.6380 \\
IX & -4456.111506 & 23.0988 \\
VIb' & -4457.300921 & 5.8487 \\
TS (VIb' - VII') & -4457.272084 & 23.9444 \\
VII' & -4457.287112 & 14.5142 \\
TS (VII' - VIII') & -4457.251144 & 37.0842 \\
VIII' & -4457.279026 & 19.5859 \\
TS (VIII - IX') & -4457.266255 & 27.6021 \\
IX' + H & -4457.270451 & 24.9687 \\
IX' & -4456.106834 & 26.0306 \\
\hline
\end{tabular}

Table S5: Computed energies of stationary points along the pathways shown in Figures S103 and S104. 


\section{S.7.5. Cyclohexane rearrangement processes of $\left[1-\mathrm{C}_{6} \mathrm{H}_{12}\right]\left[B \mathrm{Br}_{4}{ }_{4}\right]$ in the Solid State}

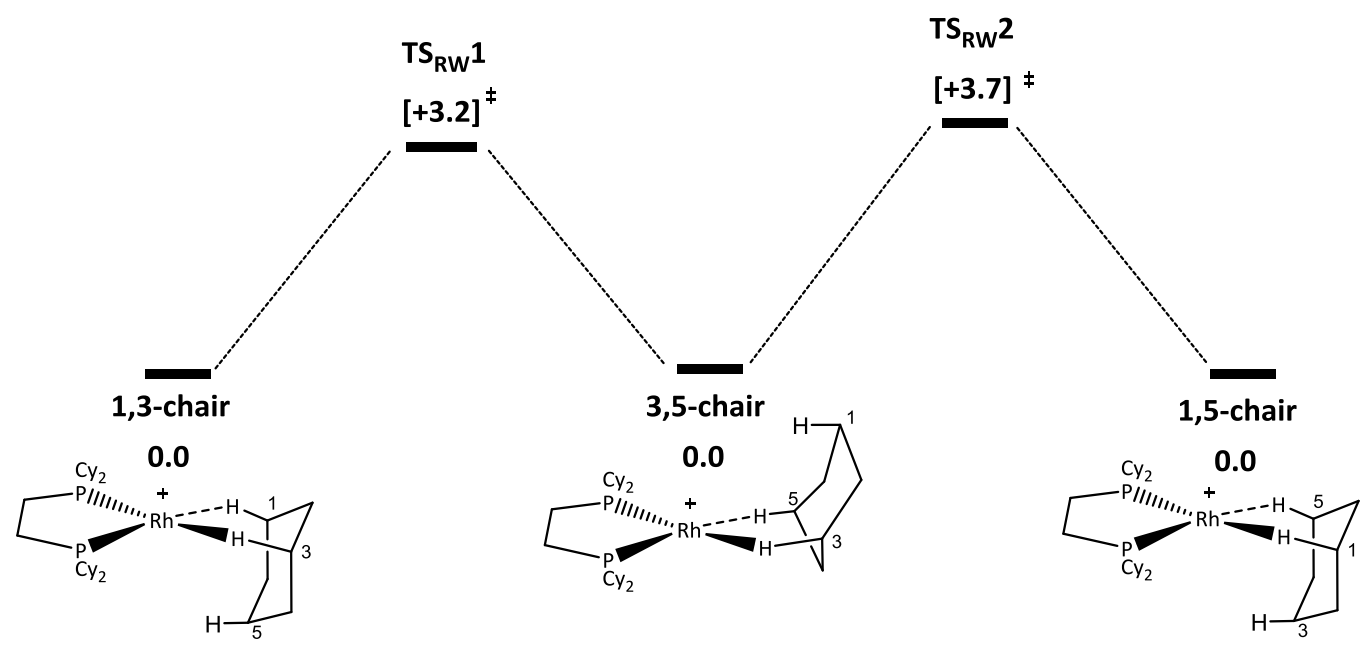

Figure S105: Computed free energy reaction profile $(\mathrm{kcal} / \mathrm{mol})$ for the $1,3,5$ ring walk in $\left[1-\mathrm{C}_{6} \mathrm{H}_{12}\right]\left[\mathrm{BAr}{ }_{4}\right]$. Only the reacting $\mathrm{Rh}$ complex is shown with $\left[\mathrm{BAr}_{4}\right]^{-}$anions and spectator Rh cations omitted for clarity.

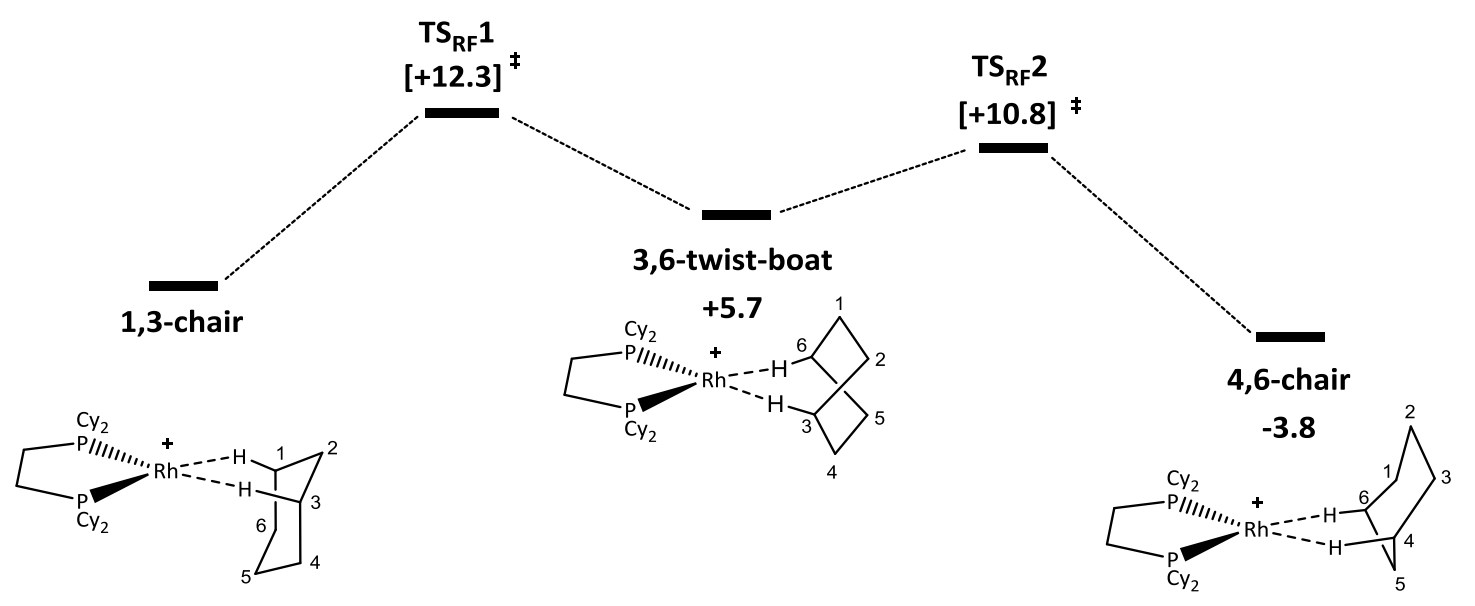

Figure S106: Computed free energy reaction profile $(\mathrm{kcal} / \mathrm{mol})$ for the ring flip of the $\left[1-\mathrm{C}_{6} \mathrm{H}_{12}\right]\left[\mathrm{BAr}_{4}{ }_{4}\right]$ system. Only the reacting $\mathrm{Rh}$ complex is shown with $\left[\mathrm{BAr}_{4}\right]^{-}$anions and spectator Rh cations omitted for clarity. 


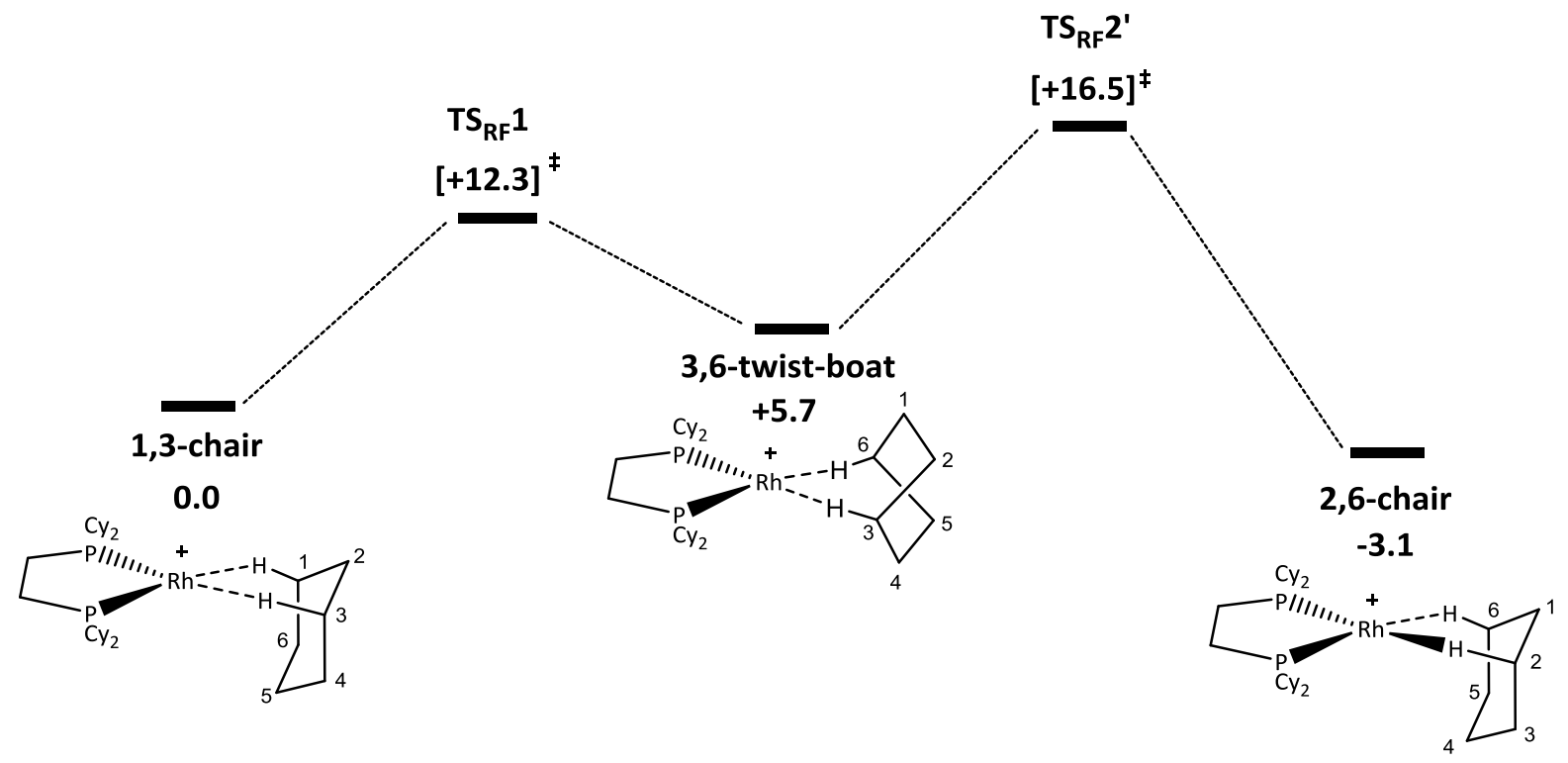

Figure S107: Computed free energy reaction profile $(\mathrm{kcal} / \mathrm{mol})$ for an alternative ring flip of the $\left[1-\mathrm{C}_{6} \mathrm{H}_{12}\right]\left[B \mathrm{Brr}_{4}{ }_{4}\right]$ system. Only the reacting $\mathrm{Rh}$ complex is shown with $\left[\mathrm{BAr}_{4}\right]^{-}$anions and spectator Rh cations omitted for clarity.

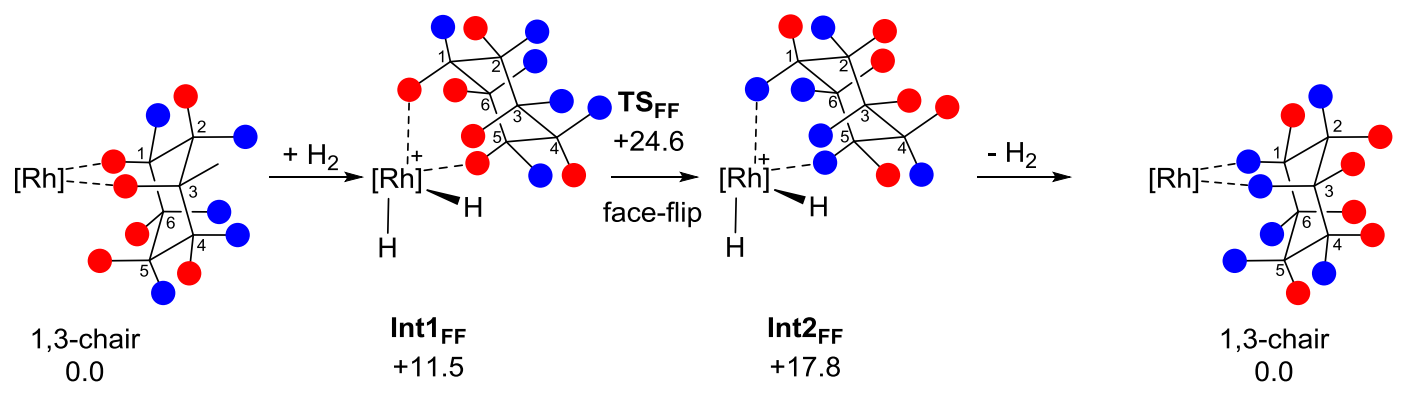

Figure S108: Computed free energies $(\mathrm{kcal} / \mathrm{mol})$ of key intermediates involved in the cyclohexane face flip in the [1- $\left.\mathrm{C}_{6} \mathrm{H}_{12}\right]\left[\mathrm{BAr}^{\mathrm{F}}{ }_{4}\right]$ system, highlighting the movement of the $\mathrm{H}$ atoms involved. Only the reacting Rh complex is shown with $\left[\mathrm{BAr}_{4}\right]^{-}$anions and spectator Rh cations omitted for clarity. 


\begin{tabular}{|c|c|c|}
\hline Solid State & $\begin{array}{c}\text { SCF Energy (a. } \\
\text { u.) }\end{array}$ & $\begin{array}{c}\text { SCF Energy Diff. (kcal / } \\
\text { mol) }\end{array}$ \\
\hline $\begin{array}{l}\text { 1,3-chair } \\
\text { TS } \\
\text { 3,5-chair } \\
\text { TS } \\
\text { 1,5-chair }\end{array}$ & $\begin{array}{l}-4462.088766 \\
-4462.086084 \\
-4462.088565 \\
-4462.085353 \\
-4462.088762\end{array}$ & $\begin{array}{c}0.0 \\
1.6825 \\
0.1261 \\
2.1414 \\
0.0022\end{array}$ \\
\hline $\begin{array}{l}\mathrm{TS}_{\mathrm{RF}} 1 \\
\text { 3,6-twist-boat } \\
\mathrm{TS}_{\mathrm{RF}} 2 \\
\text { 4,6-chair }\end{array}$ & $\begin{array}{l}-4462.068397 \\
-4462.080250 \\
-4462.067364 \\
-4462.085361\end{array}$ & $\begin{array}{c}12.7814 \\
5.3436 \\
13.4299 \\
2.1363\end{array}$ \\
\hline $\begin{array}{l}\mathrm{TS}_{\mathrm{RF}} 2^{\prime} \\
\text { 2,6-chair }\end{array}$ & $\begin{array}{l}-4462.065488 \\
-4462.087509\end{array}$ & $\begin{array}{c}14.6071 \\
0.7886\end{array}$ \\
\hline $\begin{array}{l}\text { Int1 } 1_{\mathrm{FF}} \\
\text { TS1 } \\
\text { Int2 } 2_{\mathrm{FF}}\end{array}$ & $\begin{array}{l}-4463.251501 \\
-4463.231182 \\
-4463.242107\end{array}$ & $\begin{array}{c}-0.5076 \\
12.2425 \\
5.3869\end{array}$ \\
\hline
\end{tabular}

Table S6: Computed energies of stationary points along the fluxional processes shown in Figures S105-S108. 


\section{S.8. Computed NMR Chemical Shifts}

\section{S.8.1. $\left[1-\mathrm{C}_{4} \mathrm{H}_{10}\right]\left[\mathrm{BAr}_{4}\right]$}
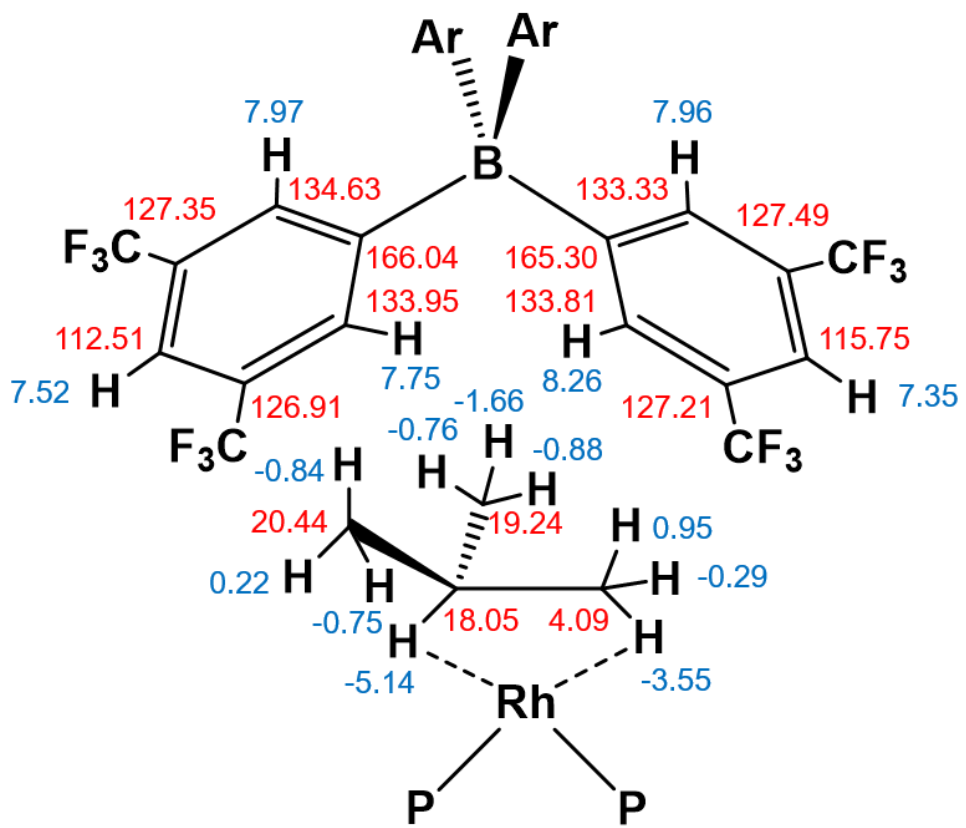

Figure S109: Computed NMR chemical shifts (ppm) for [1-C $\left.\mathbf{C}_{4} \mathbf{H}_{10}\right]\left[B \mathrm{Br}^{\mathrm{F}}\right]$ (cation 1). ${ }^{1} \mathrm{H}$ chemical shifts are shown in blue and ${ }^{13} \mathrm{C}$ shifts in red.

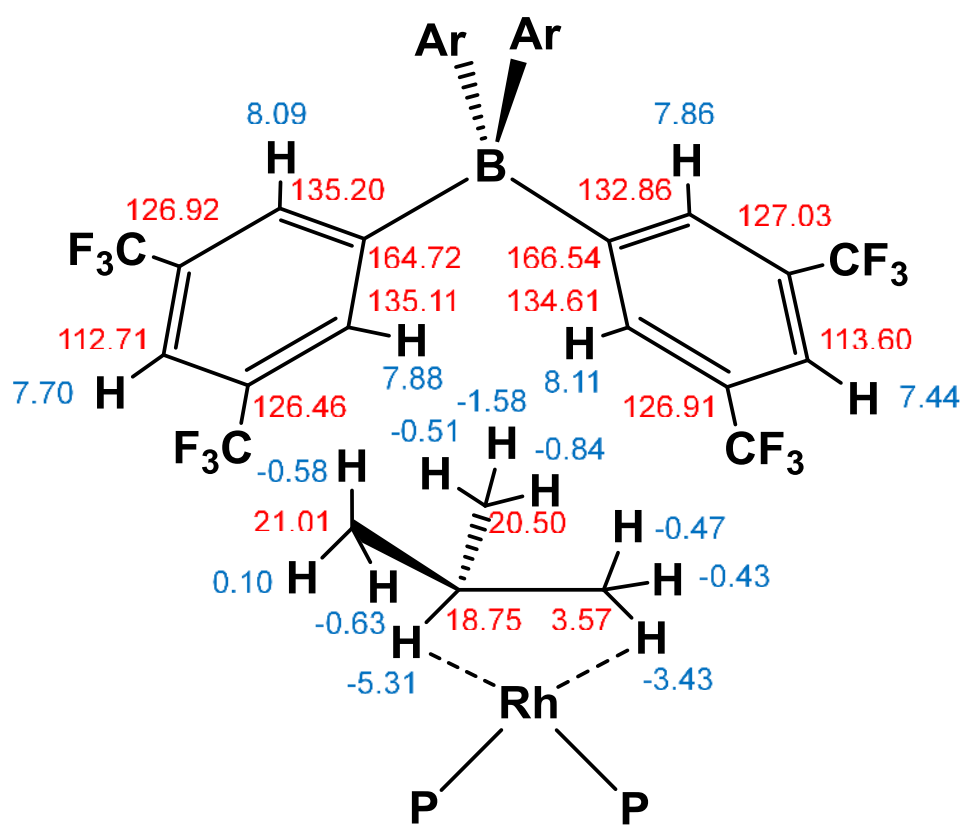

Figure S110: Computed NMR chemical shifts (ppm) for [1- $\left.\mathrm{C}_{4} \mathrm{H}_{10}\right]\left[B \mathrm{Br}_{4}{ }_{4}\right]$ (cation 2). ${ }^{1} \mathrm{H}$ chemical shifts are shown in blue and ${ }^{13} \mathrm{C}$ shifts in red. 


\section{S.8.2. $\left[1-\mathrm{C}_{6} \mathrm{H}_{12}\right]\left[B \mathrm{Br}_{4}^{\mathrm{F}}\right]$}

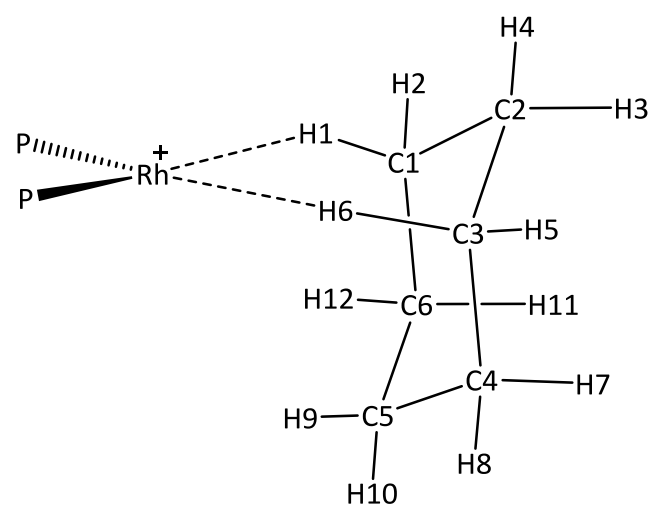

Figure S111: Labelling scheme employed.

\begin{tabular}{|c|c|c|c|c|c|c|c|c|c|}
\hline \multirow[b]{2}{*}{ Nucleus } & \multicolumn{3}{|c|}{ Model 1} & \multicolumn{3}{|c|}{ Model 2} & \multicolumn{3}{|c|}{ Ion Pair } \\
\hline & $\sigma^{\text {iso }}$ & $\delta^{1} \mathrm{H}$ & $\delta{ }^{13} \mathrm{C}$ & $\sigma^{\text {iso }}$ & $\delta^{1} \mathbf{H}$ & $\delta{ }^{13} \mathrm{C}$ & $\sigma^{\text {iso }}$ & $\delta^{1} \mathrm{H}$ & $\delta{ }^{13} \mathrm{C}$ \\
\hline $\mathrm{H} 1$ & 37.1528 & -6.00 & & 36.1609 & -5.01 & & 37.6566 & -6.51 & \\
\hline $\mathrm{H} 2$ & 30.0546 & 1.10 & & 30.4775 & 0.67 & & 30.5041 & 0.65 & \\
\hline H3 & 30.7537 & 0.40 & & 31.0223 & 0.13 & & 31.1643 & -0.01 & \\
\hline $\mathrm{H} 4$ & 29.3258 & 1.82 & & 28.8933 & 2.26 & & 30.0916 & 1.06 & \\
\hline H5 & 29.7757 & 1.37 & & 29.9983 & 1.15 & & 30.3096 & 0.84 & \\
\hline $\mathrm{H} 6$ & 36.7497 & -5.60 & & 35.7647 & -4.61 & & 37.2708 & -6.12 & \\
\hline $\mathrm{H} 7$ & 32.8162 & -1.67 & & 32.8452 & -1.70 & & 33.0983 & -1.95 & \\
\hline H8 & 30.2027 & 0.95 & & 30.0231 & 1.13 & & 30.8968 & 0.25 & \\
\hline $\mathrm{H} 9$ & 30.7822 & 0.37 & & 31.0827 & 0.07 & & 31.4869 & -0.34 & \\
\hline $\mathrm{H} 10$ & 29.4862 & 1.66 & & 29.0109 & 2.14 & & 30.2264 & 0.92 & \\
\hline $\mathrm{H} 11$ & 32.9866 & -1.84 & & 32.3977 & -1.25 & & 33.2908 & -2.14 & \\
\hline $\mathrm{H} 12$ & 30.0397 & 1.11 & & 29.5275 & 1.62 & & 30.7145 & 0.44 & \\
\hline $\mathrm{C} 1$ & 148.0118 & & 23.74 & 157.3883 & & 15.60 & 147.6427 & & 24.10 \\
\hline $\mathrm{C} 2$ & 149.5209 & & 22.29 & 148.8721 & & 23.89 & 151.8025 & & 20.08 \\
\hline C3 & 149.3763 & & 22.43 & 153.8161 & & 19.08 & 148.929 & & 22.86 \\
\hline C4 & 145.8353 & & 25.85 & 144.1107 & & 28.53 & 146.2955 & & 25.40 \\
\hline C5 & 144.7839 & & 26.86 & 144.4966 & & 28.16 & 144.7953 & & 26.85 \\
\hline C6 & 145.1803 & & 26.48 & 143.0411 & & 29.58 & 145.8146 & & 25.87 \\
\hline
\end{tabular}

Table S7: [1- $\left.\mathrm{C}_{6} \mathrm{H}_{12}\right]\left[B \mathrm{Br}_{4}{ }_{4}\right]$ computed isotropic chemical shifts $\left(\sigma^{\text {iso }}\right)$ and relative chemical shifts (ppm) using the labelling scheme shown in Figure S108. ${ }^{a}$

${ }^{a}$ Model 1 data are based on the fully optimised geometry of $\left[1-\mathrm{C}_{6} \mathrm{H}_{12}\right]\left[\mathrm{BAr}_{4}{ }_{4}\right]$ in the solid-state; Model 2: data are based on the experimental structure with only the positions of $\mathrm{H}$ and $\mathrm{F}$ atoms being optimised; ion-pair model based on the nearest neighbour ion-pair extracted from the fully optimised geometry in Model 1. 


\section{S.9. Electronic Structure Analyses}

S.9.1. $\quad\left[1-\mathrm{C}_{4} \mathrm{H}_{10}\right]\left[\mathrm{BAr}{ }_{4}\right]$

Note: Analyses were performed for both crystallographically independent cations contained in the unit cell.

\begin{tabular}{|c|c|c|c|}
\hline Distance ( $\AA$ ) & Fully Optimized & Heavy Atom Fixed ${ }^{a}$ & Experiment \\
\hline $\mathrm{Rh}-\mathrm{P} 2$ & 2.200 & 2.183 & $2.183(1)$ \\
\hline $\mathrm{Rh}-\mathrm{P} 3$ & 2.207 & 2.191 & $2.191(1)$ \\
\hline $\mathrm{Rh}-\mathrm{H} 34$ & 1.923 & 1.933 & 1.920 \\
\hline $\mathrm{Rh}-\mathrm{H} 37$ & 1.899 & 1.873 & 1.806 \\
\hline $\mathrm{Rh}-\mathrm{C} 4$ & 2.361 & 2.363 & $2.363(14)$ \\
\hline $\mathrm{Rh}-\mathrm{C} 5$ & 2.480 & 2.442 & $2.442(7)$ \\
\hline $\mathrm{C} 4-\mathrm{H} 34$ & 1.150 & 1.148 & 0.981 \\
\hline $\mathrm{C} 4-\mathrm{H} 35$ & 1.099 & 1.099 & 0.980 \\
\hline $\mathrm{C} 4-\mathrm{H} 36$ & 1.096 & 1.094 & 0.980 \\
\hline $\mathrm{C} 5-\mathrm{H} 37$ & 1.159 & 1.160 & 1.000 \\
\hline Bite Angle $\left(^{\circ}\right)$ & 87.401 & 89.322 & 76.96 \\
\hline
\end{tabular}

Table S8: Key bond distances $(\AA)$ for $\underline{1}^{\text {st }}$ Cation from fully optimised and heavy atoms fixed geometries of $\left[1-\mathrm{C}_{4} \mathrm{H}_{10}\right]\left[\mathrm{BAr}_{4}\right]$, with experimental data for comparison. ${ }^{\mathrm{S31}}$

${ }^{a}$ structure is based on the experimental structure with only the positions of $\mathrm{H}$ and $\mathrm{F}$ atoms being optimised. 


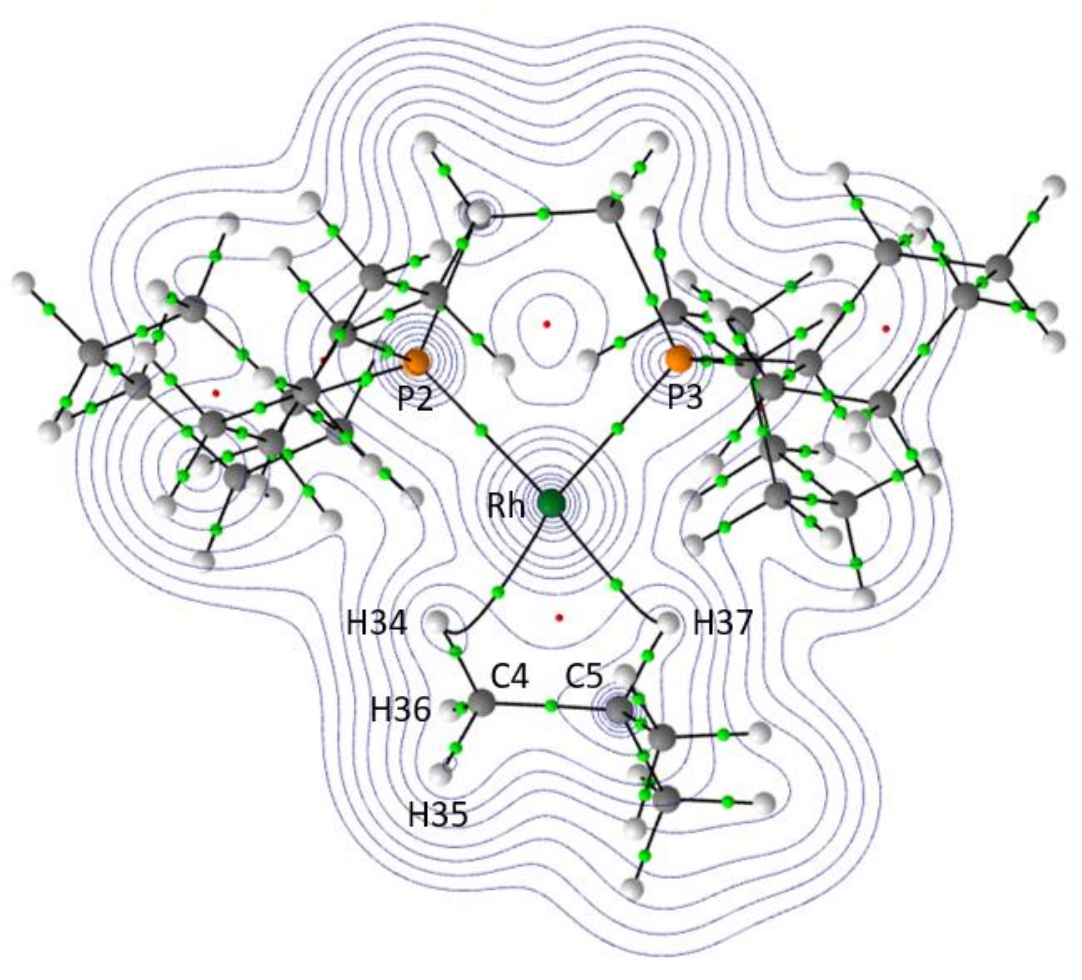

Figure S112: QTAIM molecular graph for $1^{\text {st }}$ cation of $\left[1-\mathrm{C}_{4} \mathrm{H}_{10}\right]\left[B \mathrm{Brr}_{4}\right]$ in with density contours plotted in the Rh-H34-H37 plane. ${ }^{\mathrm{S} 30}$ Bond critical points (BCPs) are indicated in green and ring critical points (RCPs) are indicated in red.

\begin{tabular}{cccc}
\hline Bond & $\boldsymbol{\rho}(\boldsymbol{r}) / \mathbf{e} \AA^{-3}$ & $\nabla^{\mathbf{2}} \boldsymbol{\rho}(\boldsymbol{r}) / \mathbf{e} \AA^{-5}$ & $\mathbf{H}(\boldsymbol{r})$ \\
\hline $\mathrm{Rh}-\mathrm{P} 2$ & 0.124 & 0.066 & -0.065 \\
$\mathrm{Rh}-\mathrm{P} 3$ & 0.123 & 0.068 & -0.063 \\
$\mathrm{Rh}-\mathrm{H} 34$ & 0.056 & 0.247 & -0.004 \\
$\mathrm{Rh}-\mathrm{H} 37$ & 0.060 & 0.241 & -0.009 \\
$\mathrm{C} 4-\mathrm{H} 34$ & 0.236 & -0.643 & -0.209 \\
$\mathrm{C} 4-\mathrm{H} 35$ & 0.271 & -0.911 & -0.272 \\
$\mathrm{C} 4-\mathrm{H} 36$ & 0.277 & -0.953 & -0.280 \\
$\mathrm{C} 5-\mathrm{H} 37$ & 0.232 & -0.601 & -0.200 \\
\hline
\end{tabular}

Table S9: Key BCP metrics for the $1^{\text {st }}$ cation of $\left[1-\mathrm{C}_{4} \mathrm{H}_{10}\right]\left[\mathrm{BAr}{ }_{4}\right]$. 


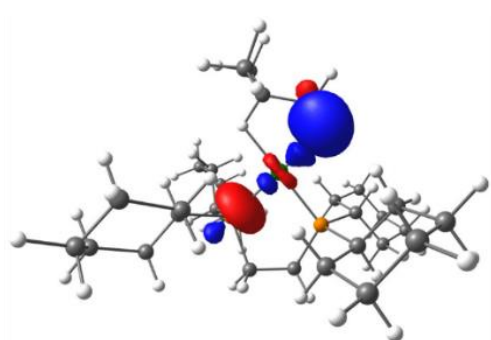

a) $\sigma_{\mathrm{C}-\mathrm{H}} \rightarrow \sigma_{\mathrm{Rh}-\mathrm{P}}^{*}:\left(22.30 \mathrm{kcal} \mathrm{mol}^{-1}\right)$

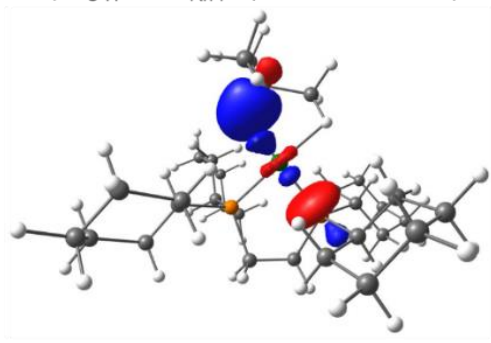

d) $\sigma_{\mathrm{C}-\mathrm{H}} \rightarrow \sigma_{\mathrm{Rh}-\mathrm{P}}^{*}:\left(21.41 \mathrm{kcal} \mathrm{mol}^{-1}\right)$

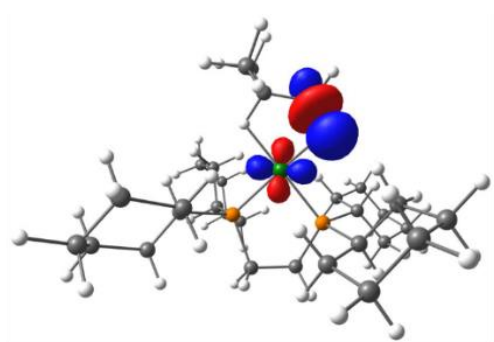

b) $\mathrm{LP}_{\mathrm{Rh}} \rightarrow \sigma_{\mathrm{C}-\mathrm{H}}^{*}:\left(3.80 \mathrm{kcal} \mathrm{mol}^{-1}\right)$

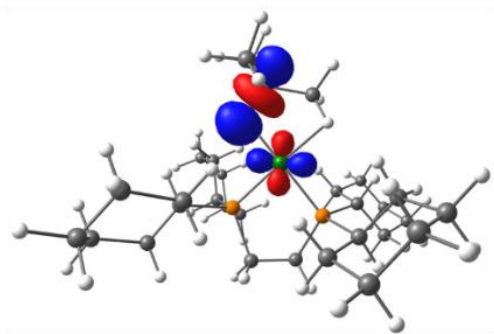

e) $\mathrm{LP}_{\mathrm{Rh}} \rightarrow \sigma^{*}{ }_{\mathrm{C}-\mathrm{H}^{*}}:\left(3.40 \mathrm{kcal} \mathrm{mol}^{-1}\right)$

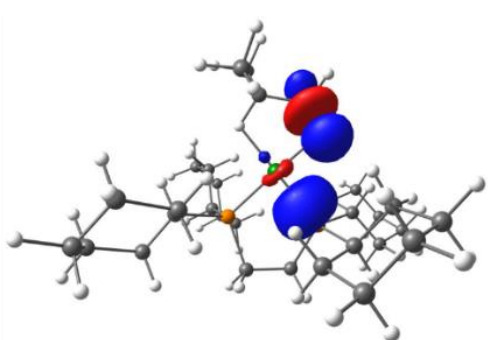

c) $\sigma_{\mathrm{Rh}-\mathrm{P}} \rightarrow \sigma_{\mathrm{C}-\mathrm{H}}^{*}:\left(2.54 \mathrm{kcal} \mathrm{mol}^{-1}\right)$

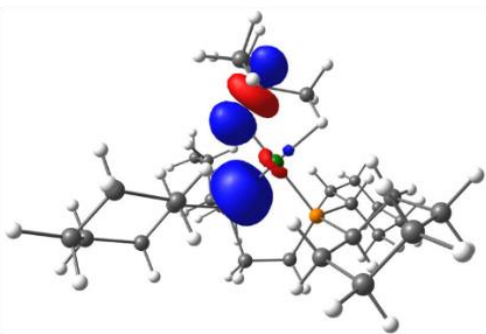

f) $\sigma_{\mathrm{Rh}-\mathrm{P}} \rightarrow \sigma_{\mathrm{C}-\mathrm{H}^{*}}^{*}\left(3.89 \mathrm{kcal} \mathrm{mol}^{-1}\right)$

Figure S113: NBO donor-acceptor pairs for the $1^{\text {st }}$ cation of $\left[1-\mathrm{C}_{4} \mathrm{H}_{10}\right]\left[\mathrm{BAr} \mathrm{F}_{4}\right]$ with NBO occupancies as indicated.

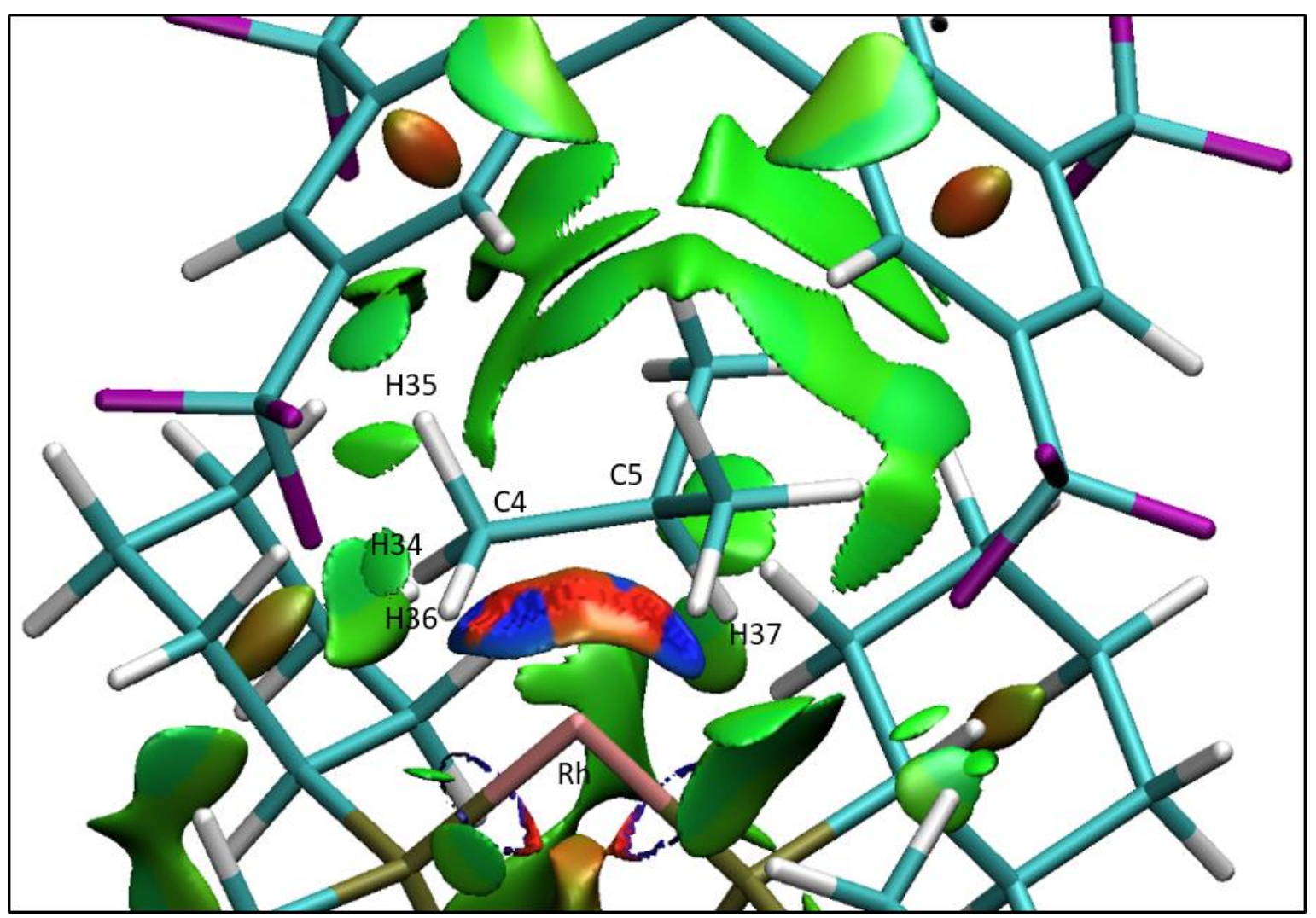

Figure S114: $\mathrm{NCl}$ plot of the $1^{\text {st }}$ cation of $\left[1-\mathrm{C}_{4} \mathrm{H}_{10}\right]\left[\mathrm{BAr}{ }_{4}\right]$ ion-pair. Isosurfaces generated for $s=0.3$ au and $-0.07<\rho<0.07$ au. 


\begin{tabular}{|c|c|c|c|}
\hline Distance $(\AA)$ & Fully Optimized & Heavy Atom Fixed ${ }^{a}$ & Experiment \\
\hline $\mathrm{Rh}-\mathrm{P} 2$ & 2.203 & 2.184 & $2.184(1)$ \\
\hline $\mathrm{Rh}-\mathrm{P} 3$ & 2.206 & 2.189 & $2.189(1)$ \\
\hline $\mathrm{Rh}-\mathrm{H} 34$ & 1.934 & 1.955 & 1.981 \\
\hline $\mathrm{Rh}-\mathrm{H} 37$ & 1.885 & 1.868 & 1.798 \\
\hline $\mathrm{Rh}-\mathrm{C} 4$ & 2.383 & 2.390 & $2.390(14)$ \\
\hline $\mathrm{Rh}-\mathrm{C} 5$ & 2.480 & 2.438 & $2.438(8)$ \\
\hline $\mathrm{C} 4-\mathrm{H} 34$ & 1.147 & 1.145 & 1.098 \\
\hline $\mathrm{C} 4-\mathrm{H} 35$ & 1.100 & 1.099 & 1.098 \\
\hline $\mathrm{C} 4-\mathrm{H} 36$ & 1.096 & 1.094 & 1.098 \\
\hline C5 - H37 & 1.160 & 1.159 & 1.001 \\
\hline Bite Angle $\left(^{\circ}\right)$ & 87.283 & 89.324 & 76.70 \\
\hline
\end{tabular}

Table S10: Key bond distances $(\AA)$ for the $\underline{2}^{\text {nd }}$ cation of [1- $\left.{ }_{4} \mathrm{H}_{10}\right]\left[B A \mathrm{~F}_{4}{ }_{4}\right]$ from fully optimised and heavy atoms fixed geometries of the $1^{\text {st }}$ cation of [1- $\left.\mathrm{C}_{4} \mathrm{H}_{10}\right]\left[\mathrm{BAr}{ }_{4}\right]$, with experimental data for comparison. ${ }^{531}$

${ }^{a}$ structure is based on the experimental structure with only the positions of $\mathrm{H}$ and $\mathrm{F}$ atoms being optimised.

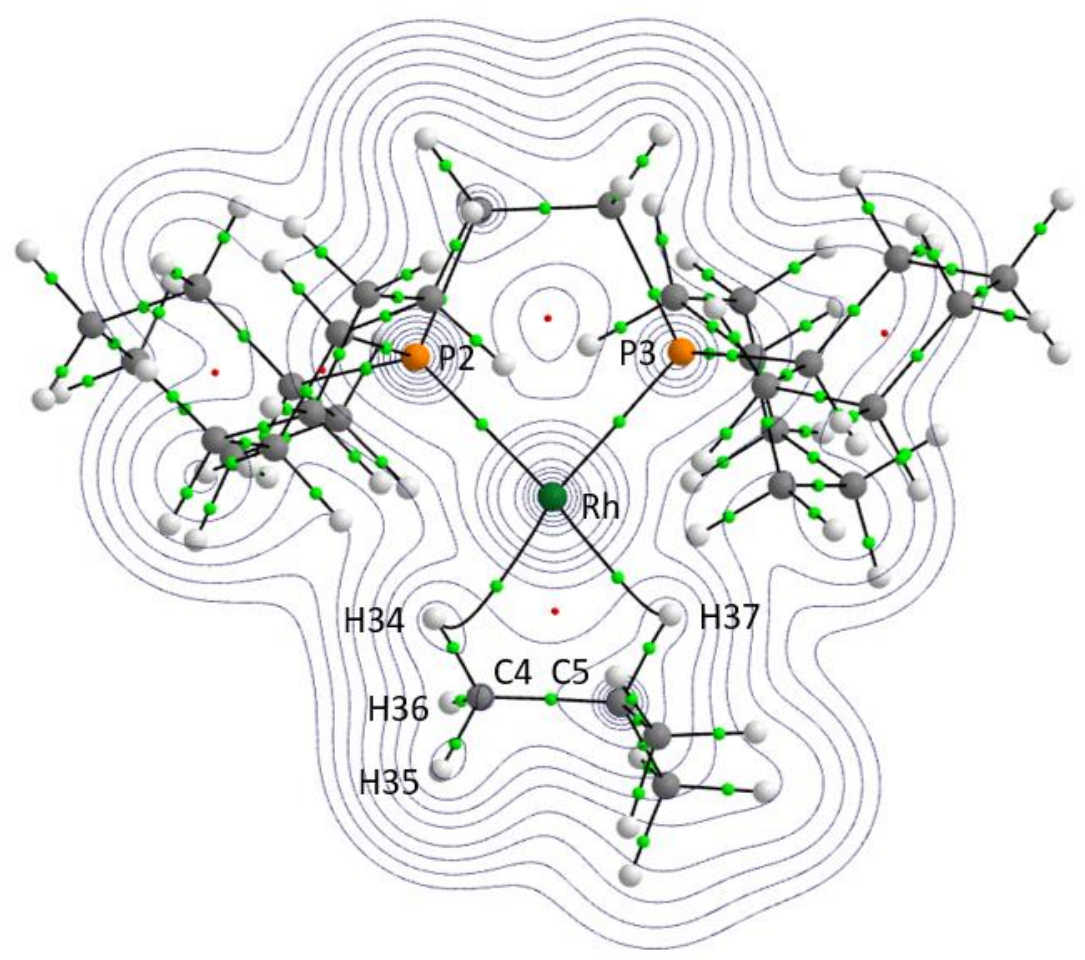

Figure S115: QTAIM molecular graph for the $2^{\text {nd }}$ cation of $\left[1-\mathrm{C}_{4} \mathrm{H}_{10}\right]\left[B \mathrm{Br}_{4}{ }_{4}\right]$, with density contours plotted in the Rh-H34-H37 plane. ${ }^{\mathrm{S} 30}$ Bond critical points (BCPs) are indicated in green and ring critical points (RCPs) are indicated in red. 


\begin{tabular}{cccc}
\hline Bond & $\boldsymbol{\rho}(\boldsymbol{r}) / \mathbf{e}^{-3}$ & $\nabla^{\mathbf{2}} \boldsymbol{\rho}(\boldsymbol{r}) / \mathbf{e} \AA^{-5}$ & $\mathbf{H}(\boldsymbol{r})$ \\
\hline Rh - P2 & 0.124 & 0.070 & -0.064 \\
Rh - P3 & 0.124 & 0.061 & -0.064 \\
Rh - H34 & 0.053 & 0.235 & -0.003 \\
Rh - H37 & 0.061 & 0.245 & -0.009 \\
C4 - H34 & 0.239 & -0.659 & -0.213 \\
C4 - H35 & 0.271 & -0.919 & -0.272 \\
C4 - H36 & 0.277 & -0.954 & -0.281 \\
C5- H37 & 0.232 & -0.608 & -0.201 \\
\hline
\end{tabular}

Table S11: Key BCP metrics for the $2^{\text {nd }}$ cation of $\left[1-\mathrm{C}_{4} \mathrm{H}_{10}\right]\left[\mathrm{BAr}{ }_{4}\right]$.

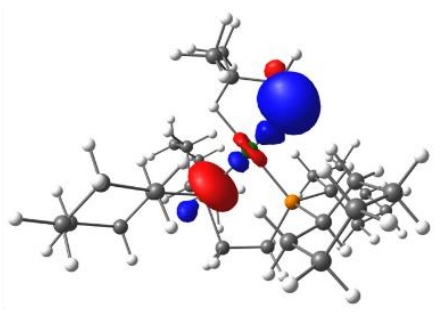

a) $\sigma_{\mathrm{C}-\mathrm{H}} \rightarrow \sigma_{\mathrm{Rh}-\mathrm{P}}^{*}:\left(20.16 \mathrm{kcal} \mathrm{mol}^{-1}\right)$

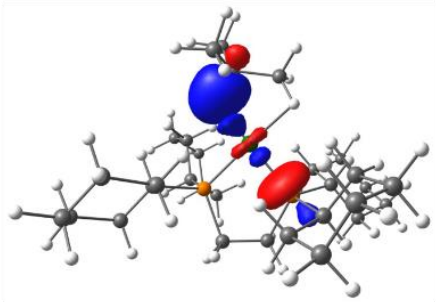

d) $\sigma_{\mathrm{C}-\mathrm{H}} \rightarrow \sigma_{\mathrm{Rh}-\mathrm{P}}^{*}:\left(21.05 \mathrm{kcal} \mathrm{mol}^{-1}\right)$

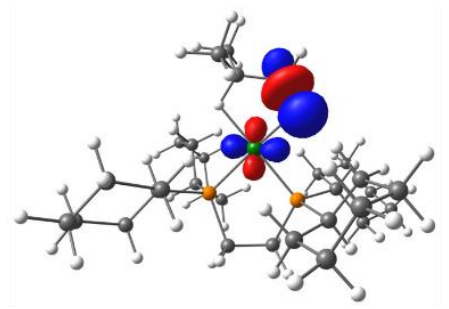

b) $\mathrm{LP}_{\mathrm{Rh}} \rightarrow \sigma^{*}{ }_{\mathrm{C}-\mathrm{H}}:\left(3.13 \mathrm{kcal} \mathrm{mol}^{-1}\right)$

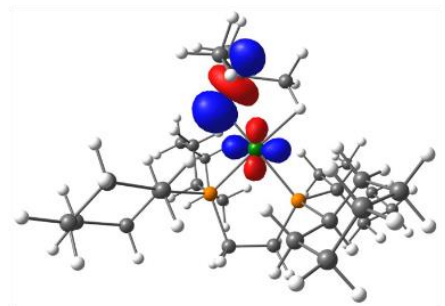

e) $\mathrm{LP}_{\mathrm{Rh}} \rightarrow \sigma^{*}{ }_{\mathrm{CH}}:\left(3.57 \mathrm{kcal} \mathrm{mol}^{-1}\right)$

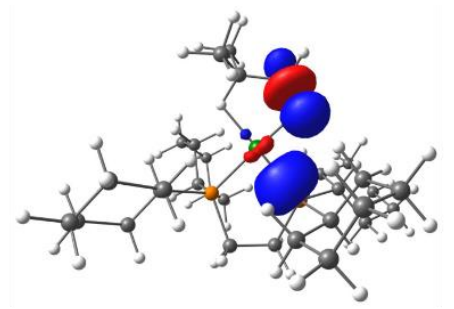

c) $\sigma_{\mathrm{Rh}-\mathrm{P}} \rightarrow \sigma^{*}{ }_{\mathrm{C}-\mathrm{H}}:\left(2.56 \mathrm{kcal} \mathrm{mol}^{-1}\right)$

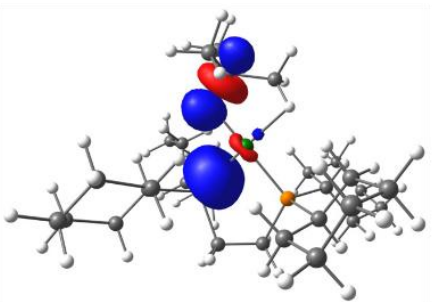

f) $\sigma_{\text {Rh-P }} \rightarrow \sigma^{*}{ }_{C-H}:\left(3.78 \mathrm{kcal} \mathrm{mol}^{-1}\right)$

Figure S116: NBO donor-acceptor pairs for the $2^{\text {nd }}$ cation of $\left[1-\mathrm{C}_{4} \mathrm{H}_{10}\right]\left[\mathrm{BAr}{ }_{4}\right]$ with NBO occupancies as indicated. 


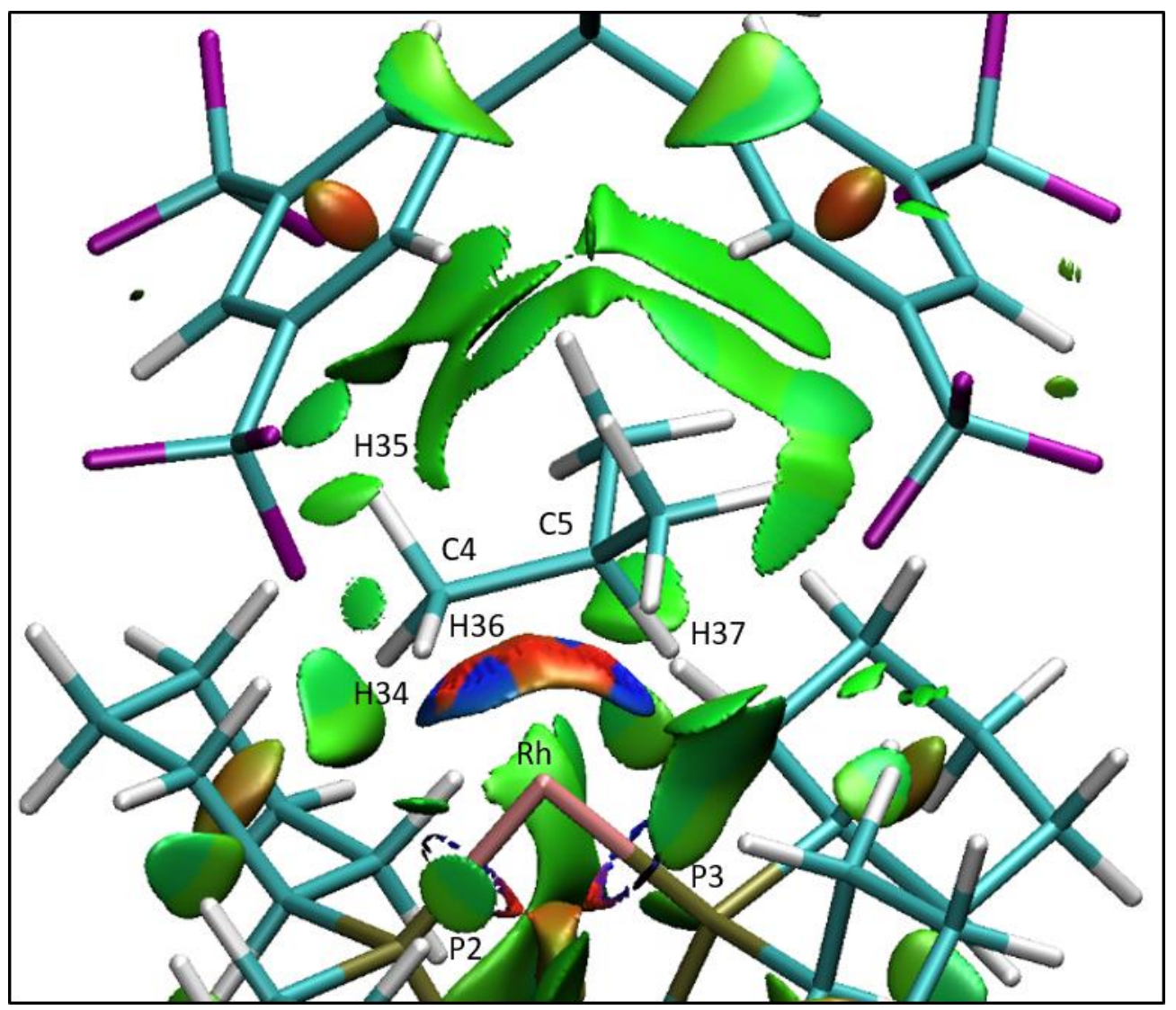

Figure S117: $\mathrm{NCl}$ plot for the $2^{\text {nd }}$ cation of $\left[1-\mathrm{C}_{4} \mathrm{H}_{10}\right]\left[\mathrm{BAr}{ }_{4}{ }^{\mathrm{C}}\right]$ ion-pair. Isosurfaces generated for $s=0.3$ au and $-0.07<\rho<0.07$ au. 


\section{S.9.2. $\quad\left[1-\mathrm{C}_{6} \mathrm{H}_{12}\right]\left[B \mathrm{Br}_{4}{ }_{4}\right]$}

\begin{tabular}{cccc}
\hline Distance $(\AA)$ & Fully Optimised & Heavy Atom Fixed $^{\text {a }}$ & Experiment $^{\text {Hed }}$ \\
\hline $\mathrm{Rh}-\mathrm{P} 1$ & 2.201 & 2.192 & $2.192(2)$ \\
$\mathrm{Rh}-\mathrm{P} 2$ & 2.195 & 2.192 & $2.192(2)$ \\
$\mathrm{Rh}-\mathrm{C} 1$ & 2.679 & 2.530 & $2.530(2)$ \\
$\mathrm{Rh}-\mathrm{C} 3$ & 2.681 & 2.642 & $2.642(2)$ \\
$\mathrm{Rh}-\mathrm{H} 11$ & 1.928 & 1.852 & 1.777 \\
$\mathrm{Rh}-\mathrm{H} 31$ & 1.923 & 1.933 & 1.931 \\
$\mathrm{Rh}-\mathrm{H} 51$ & 2.677 & 2.668 & 2.721 \\
$\mathrm{C} 1-\mathrm{H} 11$ & 1.140 & 1.141 & 0.970 \\
$\mathrm{C} 1-\mathrm{H} 12$ & 1.101 & 1.100 & 0.970 \\
$\mathrm{C} 3-\mathrm{H} 31$ & 1.139 & 1.137 & 0.970 \\
$\mathrm{C} 3-\mathrm{H} 32$ & 1.100 & 1.099 & 0.971 \\
$\mathrm{C} 5-\mathrm{H} 44$ & 1.109 & 1.109 & 0.970 \\
$\mathrm{C} 5-\mathrm{H} 45$ & 1.098 & 1.094 & 0.970 \\
\hline
\end{tabular}

Table S12: Key bond distances ( $(\AA)$ for fully optimised and heavy atoms fixed geometries, compared with experimental data. ${ }^{S 31}$

${ }^{a}$ struture is based on the experimental structure with only the positions of $\mathrm{H}$ and $\mathrm{F}$ atoms being optimised.

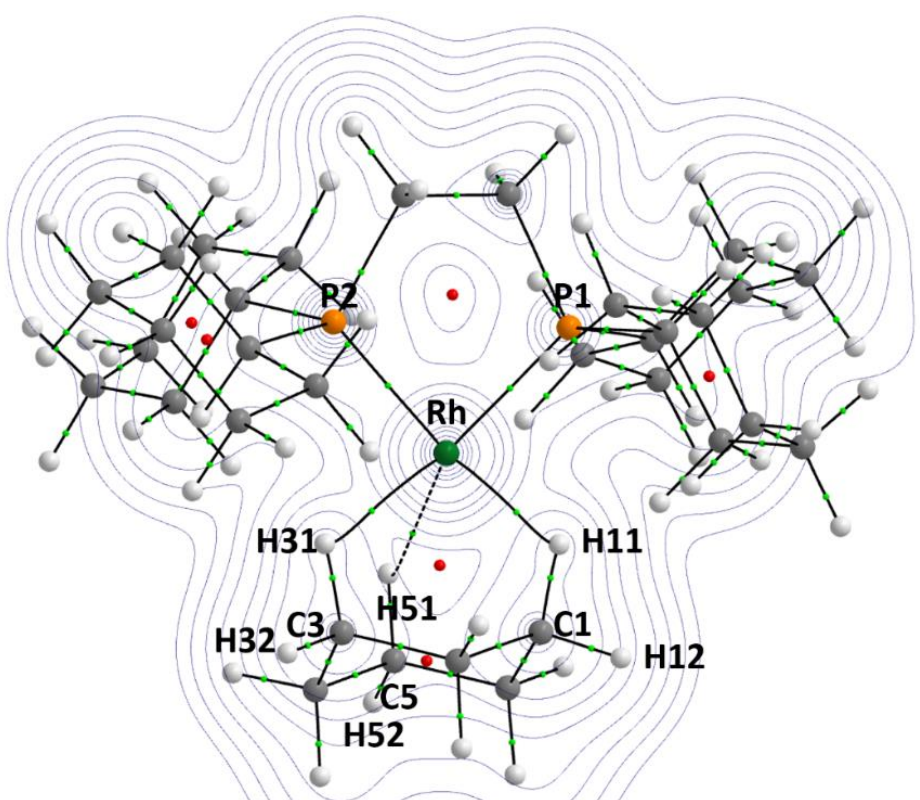

Figure S118: QTAIM molecular graph with density contours plotted in the Rh-H11H31 plane. Bond critical points (BCPs) are indicated in green and ring critical points (RCPs) are indicated in red. 


\begin{tabular}{cccc}
\hline Bond & $\boldsymbol{\rho}(\boldsymbol{r}) / \mathbf{e}^{-3}$ & $\nabla^{2} \boldsymbol{\rho}(\boldsymbol{r}) / \mathbf{e}^{-5}$ & $\mathbf{H}(\boldsymbol{r})$ \\
\hline Rh-P1 & 0.123 & 0.065 & -0.063 \\
$\mathrm{Rh}-\mathrm{P} 2$ & 0.123 & 0.070 & -0.063 \\
$\mathrm{Rh}-\mathrm{H} 11$ & 0.061 & 0.226 & -0.011 \\
$\mathrm{Rh}-\mathrm{H} 31$ & 0.050 & 0.181 & -0.008 \\
$\mathrm{Rh}-\mathrm{H} 51$ & 0.015 & 0.041 & 0.000 \\
$\mathrm{C} 1-\mathrm{H} 11$ & 0.239 & -0.648 & -0.214 \\
$\mathrm{C} 1-\mathrm{H} 12$ & 0.274 & -0.920 & -0.274 \\
$\mathrm{C} 3-\mathrm{H} 31$ & 0.242 & -0.671 & -0.219 \\
$\mathrm{C} 3-\mathrm{H} 32$ & 0.274 & -0.922 & -0.274 \\
$\mathrm{C} 5-\mathrm{H} 51$ & 0.266 & -0.853 & -0.259 \\
$\mathrm{C} 5-\mathrm{H} 52$ & 0.276 & -0.932 & -0.279 \\
\hline
\end{tabular}

Table S13. Key BCP metrics of [1- $\left.\mathrm{C}_{6} \mathrm{H}_{12}\right]\left[\mathrm{BAr}{ }_{4}{ }_{4}\right]$

\begin{tabular}{ccc}
\hline Donor & Acceptor & $\mathbf{E ( 2 )}(\mathbf{k c a l} / \mathbf{~ m o l})$ \\
\hline Rh LP & $\sigma^{*} \mathrm{C} 1-\mathrm{H} 11$ & 4.26 \\
$\sigma \mathrm{Rh}-\mathrm{P} 1$ & $\sigma^{*} \mathrm{C} 1-\mathrm{H} 11$ & 5.99 \\
$\sigma \mathrm{Rh}-\mathrm{P} 2$ & $\sigma^{*} \mathrm{C} 1-\mathrm{H} 11$ & 1.63 \\
$\sigma \mathrm{C} 1-\mathrm{H} 11$ & $\sigma^{*} \mathrm{Rh}-\mathrm{P} 2$ & 20.03 \\
Rh LP & $\sigma^{*} \mathrm{C} 3-\mathrm{H} 31$ & 2.60 \\
$\sigma \mathrm{Rh}-\mathrm{P} 1$ & $\sigma^{*} \mathrm{C} 3-\mathrm{H} 31$ & 1.76 \\
$\sigma \mathrm{Rh}-\mathrm{P} 2$ & $\sigma^{*} \mathrm{C} 3-\mathrm{H} 31$ & 5.45 \\
$\sigma \mathrm{C} 3-\mathrm{H} 31$ & $\sigma^{*} \mathrm{Rh}-\mathrm{P} 1$ & 15.13 \\
\hline
\end{tabular}

Table S14: Key donor-acceptor interactions from the NBO second order perturbation analysis of [1- $\left.\mathrm{C}_{6} \mathrm{H}_{12}\right]\left[\mathrm{BAr}{ }_{4}\right]$. 


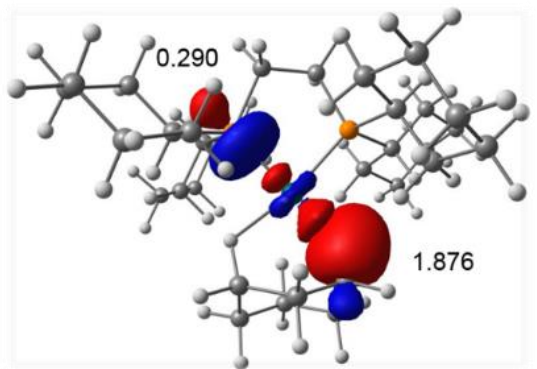

(a) $\sigma_{\mathrm{C} 1-\mathrm{H} 11} \rightarrow \sigma_{\mathrm{Rh}-\mathrm{P} 2}(20.03 \mathrm{kcal} / \mathrm{mol})$

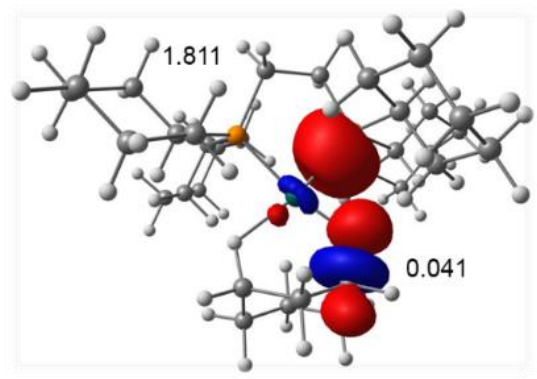

(c) $\sigma_{\mathrm{Rh}-\mathrm{P} 1} \rightarrow \sigma^{*}{ }_{\mathrm{C} 1-\mathrm{H} 11}(5.99 \mathrm{kcal} / \mathrm{mol})$

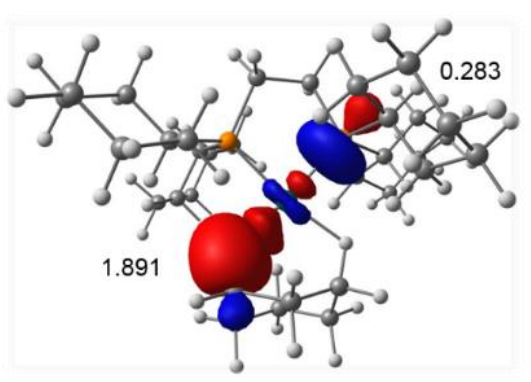

(e) $\sigma_{\mathrm{C} 3-\mathrm{H} 31} \rightarrow \sigma_{\mathrm{Rh}-\mathrm{P} 1}^{*}(15.13 \mathrm{kcal} / \mathrm{mol})$

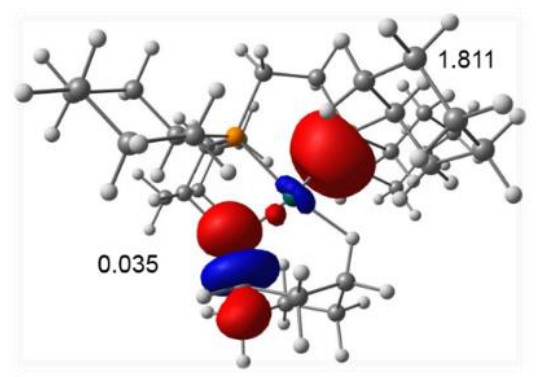

(g) $\sigma_{\mathrm{Rh}-\mathrm{P} 1} \rightarrow \sigma_{\mathrm{C} 3-\mathrm{H} 31}(1.76 \mathrm{kcal} / \mathrm{mol})$

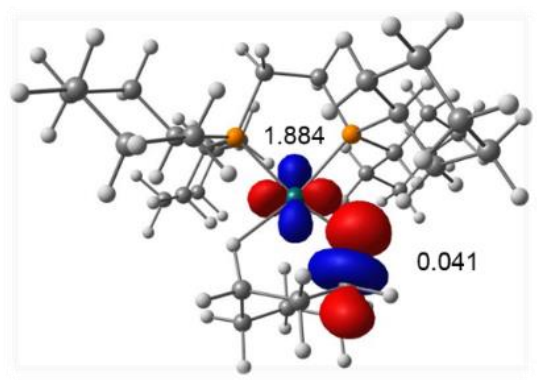

(b) $\mathrm{Rh}_{\mathrm{LP}} \rightarrow \sigma_{\mathrm{C} 1-\mathrm{H} 11}^{*}(4.26 \mathrm{kcal} / \mathrm{mol})$

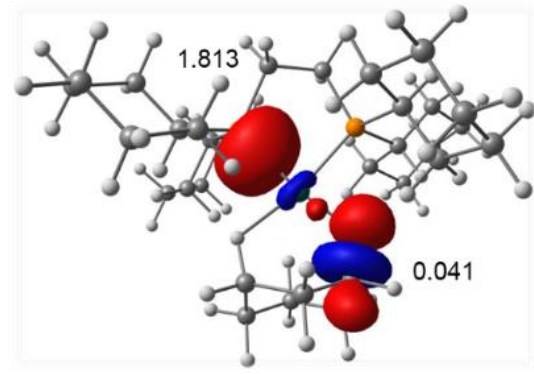

(d) $\sigma_{\mathrm{Rh}-\mathrm{P} 2} \rightarrow \sigma^{*}{ }_{\mathrm{C} 1-\mathrm{H} 11}(1.63 \mathrm{kcal} / \mathrm{mol})$

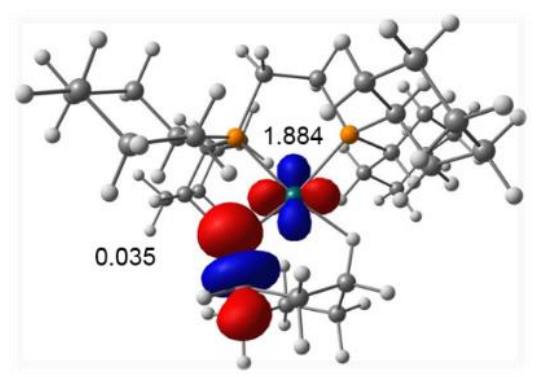

(f) $\mathrm{Rh}_{\mathrm{LP}} \rightarrow \sigma_{\mathrm{C} 3-\mathrm{H} 31}(2.60 \mathrm{kcal} / \mathrm{mol})$

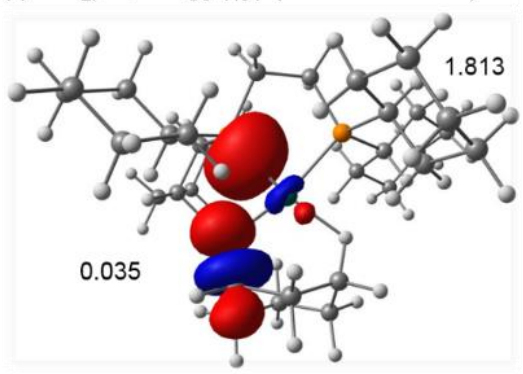

(h) $\sigma_{\mathrm{Rh}-\mathrm{P} 2} \rightarrow \sigma_{\mathrm{C} 3-\mathrm{H} 31}(5.45 \mathrm{kcal} / \mathrm{mol})$

Figure S119: NBO donor-acceptor pairs for $\left[1-\mathrm{C}_{6} \mathrm{H}_{12}\right]\left[B \mathrm{Br}_{4}{ }_{4}\right]$ with NBO occupancies as indicated. 

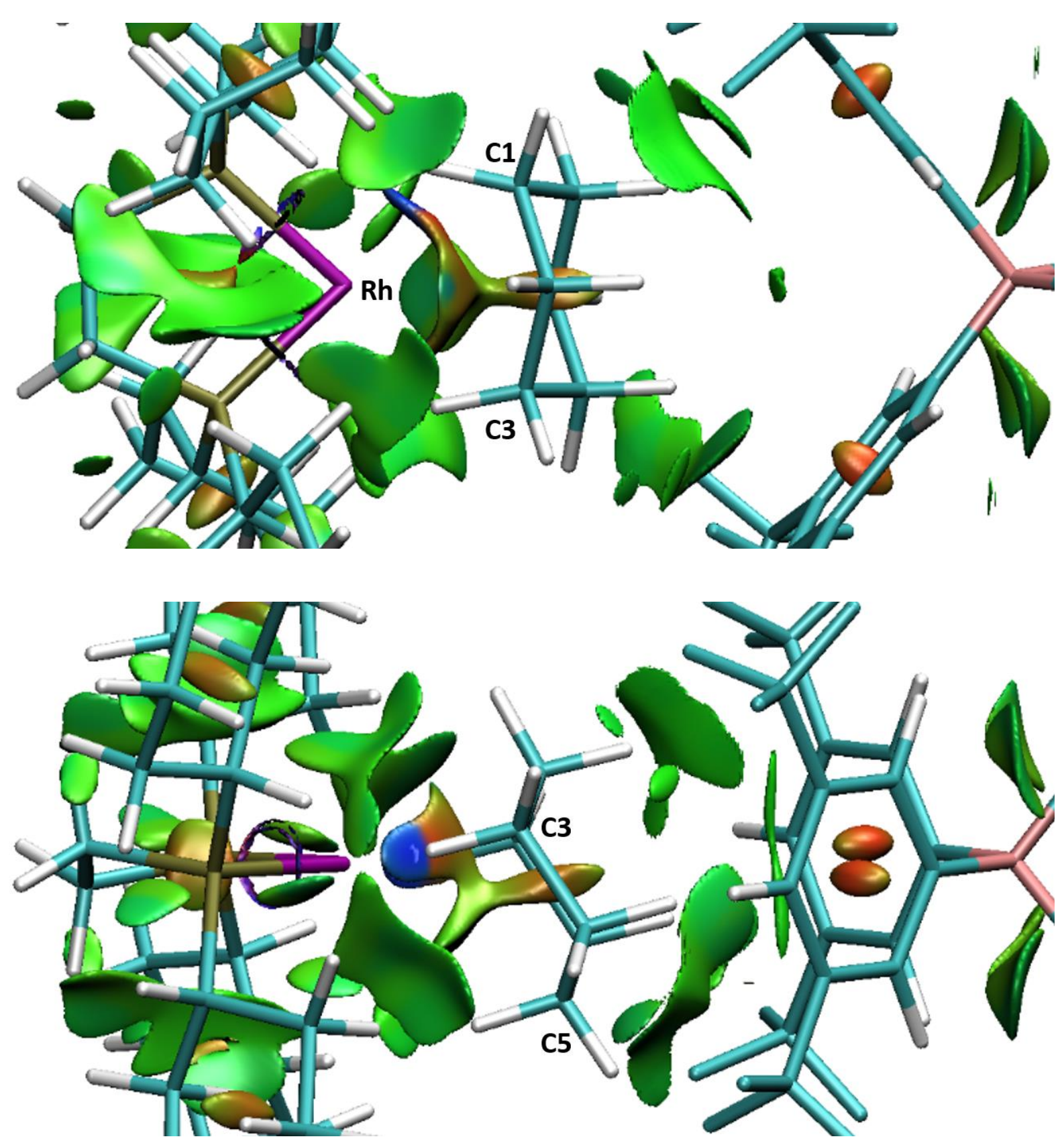

Figure S120: Two views of the $\mathrm{NCl}$ plots of the $\left[1-\mathbf{C}_{6} \mathbf{H}_{12}\right]\left[B A \mathbf{B r}_{4}\right]$ ion-pair. Isosurfaces generated for $s=0.3$ au and $-0.07<\rho$ Isosurface 


\section{S.10. References}

S1 Chadwick, F. M.; Rees, N. H.; Weller, A. S.; Krämer, T.; lannuzzi, M.; Macgregor, S. A. A Rhodium-Pentane Sigma-Alkane Complex: Characterization in the Solid State by Experimental and Computational Techniques. Angew. Chemie - Int. Ed. 2016, 55 (11), 3677.

S2 Pike, S. D.; Chadwick, F. M.; Rees, N. H.; Scott, M. P.; Weller, A. S.; Krämer, T.; Macgregor, S. A. Solid-State Synthesis and Characterization of $\sigma$-Alkane Complexes, [Rh(L2)(H2,H2-C7H12)][BArF4] (L2 = Bidentate Chelating Phosphine). J. Am. Chem. Soc. 2015, 137 (2), 820.

S3 Earl, W. L.; Vanderhart, D. L. Measurement Of 13C Chemical Shifts in Solids. J. Magn. Reson. 1982, 48 (1), 35.

S4 McKay, A. I.; Krämer, T.; Rees, N. H.; Thompson, A. L.; Christensen, K. E.; Macgregor, S. A.; Weller, A. S. Formation of a $\sigma$-Alkane Complex and a Molecular Rearrangement in the Solid-State: [Rh(Cyp 2 PCH 2 CH 2 PCyp 2 )(n 2 :n 2 -C 7 H 12 )][BArF4 ]. Organometallics 2017, 36 (1), 22.

S5 Pike, S. D.; Krämer, T.; Rees, N. H.; Macgregor, S. A.; Weller, A. S. Stoichiometric and Catalytic Solid-Gas Reactivity of Rhodium Bis-Phosphine Complexes. Organometallics 2015, 34 (8), 1487.

S6 Lubben, A. T.; Scott Mclndoe, J.; Weller, A. S. Coupling an Electrospray lonwization Mass Spectrometer with a Glovebox: A Straightforward, Powerful, and Convenient Combination for Analysis of Air-Sensitive Organometallics. Organometallics 2008, 27 (13), 3303.

S7 Chadwick, F. M.; McKay, A. I.; Martinez-Martinez, A. J.; Rees, N. H.; Krämer, T.; Macgregor, S. A.; Weller, A. S. Solid-State Molecular Organometallic Chemistry. Single-Crystal to Single-Crystal Reactivity and Catalysis with Light Hydrocarbon Substrates. Chem. Sci. 2017, 8 (9), 6014.

S8 Newsome, G. A.; Steinkamp, F. L.; Giordano, B. C. Isobutane Made Practical as a Reagent Gas for Chemical Ionization Mass Spectrometry. J. Am. Soc. Mass Spectrom. 2016, 27 (11), 1789.

S9 Benedict, J. B.; Coppens, P. Kinetics of the Single-Crystal to Single-Crystal TwoPhoton Photodimerization of $\alpha$-Trans-Cinnamic Acid to $\alpha$-Truxillic Acid. J. Phys. Chem. A 2009, 113 (13), 3116.

S10 Hoops, S.; Sahle, S.; Gauges, R.; Lee, C.; Pahle, J.; Simus, N.; Singhal, M.; Xu, L.; Mendes, P.; Kummer, U. COPASI--a COmplex PAthway SImulator. Bioinformatics 2006, 22 (24), 3067.

S11 Cosier, B. J.; Glazer, A. M. A Nitrogen-Gas-Stream Cryostat for General X-Ray Diffraction Studies. J. Appl. Crystallogr. 1986, 19 (2), 105.

S12 Oxford Diffraction Ltd.; 2011.

S13 Sheldrick, G. M. A Short History of SHELX. Acta Crystallogr. Sect. A Found. Crystallogr. 2008, 64 (1), 112.

S14 Sheldrick, G. M. SHELXT - Integrated Space-Group and Crystal-Structure Determination. Acta Crystallogr. Sect. A Found. Crystallogr. 2015, 71 (1), 3. 
S15 Dolomanov, O. V.; Bourhis, L. J.; Gildea, R. J.; Howard, J. A. K.; Puschmann, H. OLEX2: A Complete Structure Solution, Refinement and Analysis Program. J. Appl. Crystallogr. 2009, 42 (2), 339.

S16 Van de Vondele, J.; Krack, M.; Mohamed, F.; Parrinello, M.; Chassaing, T.; Hutter, J.Comput. QUICKSTEP: Fast and accurate density functional calculations using a mixed Gaussian and plane waves approach. Phys. Commun. 2005, 167, 103.

S17 Hutter, J.; Iannuzzi, M.; Schiffmann, F.; VandeVondele. CP2K: atomistic simulations of condensed matter systems. J. Wires Comput. Mol. Sci. 2014, 4, 15.

S18 VandeVondele, J.; Hutter, J. Gaussian basis sets for accurate calculations on molecular systems in gas and condensed phases. J. Chem. Phys. 2007, 127, 114105.

S19 Hartwigsen, C.; Goedecker, S.; Hutter, J. Relativistic separable dual-space Gaussian pseudopotentials from H to Rn. Phys. Rev. B 1998, 58, 3641.

S20 Goedecker, S.; Teter, M.; Hutter, J.; Separable duel-space Gaussian pseudopotentials. J. Phys. Rev. B 1996, 54, 1703.

S21 Krack, M. Pseudopotentials for $\mathrm{H}$ to $\mathrm{Kr}$ optimized for gradient-corrected exchangecorrelation functionals. Theor. Chem. Acc. 2005, 114, 145.

S22 Perdew, J. P.; Burke, K.; Ernzerhof, M. Generalized Gradient Approximation Made Simple. Phys. Rev. Lett. 1996, 77, 3865.

S23 Grimme, S.; Antony, J.; Ehrlich, S.; Krieg, H. A consistent and accurate ab initio parametrization of density functional dispersion correction (DFT-D) for the 94 elements H-Pu. J. Chem. Phys. 2010, 132, 154104.

S24 Henkelman, G.; Jonsson, H. A dimer method for finding saddle points on high dimensional potential surfaces using only first derivatives. J. Chem. Phys. 1999, 111, 7010 .

S25 Henkelman, G.; Uberuaga, B. P.; Jonsson, H. A climbing image nudged elastic band method for finding saddle points and minimum energy paths. J. Chem. Phys. 2000, $113,9901$.

S26 Chadwick, F. M.; Krämer, T.; Gutmann, T.; Rees, N. H.; Thompson, A. L.; Edwards, A. J.; Buntkowsky, G.; Macgregor, S. A.; Weller, A. S. Selective C-H Activation at a Molecular Rhodium Sigma-Alkane Complex by Solid/Gas Single-Crystal to SingleCrystal H/D Exchange. J. Am. Chem. Soc. 2016, 138, 13369.

S27 Brogaard, R. Y.; Weckhuysen, B. M.; Noerskov, J. K. Guest-host interactions of arenes in H-ZSM-5 and their impact on methanol-to-hydrocarbons deactivation processes. J. Catal. 2013, 300, 235.

S28 Piccini, G.; Sauer, J. Quantum Chemical Free Energies: Structure Optimization and Vibrational Frequencies in Normal Modes. J. Chem. Theory Comput. 2013, 9, 5038.

S29 Ghysels, A.; Verstraelen, T.; Hemelsoet, K.; Waroquier, M.; Van Speybroeck, V. TAMkin: A Versatile Package for Vibrational Analysis and Chemical Kinetics $J$. Chem. Inf. Model. 2010, 50, 1736. 
S30 Gaussian 09 (Revision D.01); Frisch, M. J.; Trucks, G. W.; Schlegel, H. B.; Scuseria, G. E.; Robb, M. A.; Cheeseman, J. R.; Scalmani, G.; Barone, V.; Mennucci, B.; Petersson, G. A.; Nakatsuji, H.; Caricato, M.; Li, X.; Hratchian, H. P.; Izmaylov, A. F.; Bloino, J.; Zheng, G.; Sonnenberg, J. L.; Hada, M.; Ehara, M.; Toyota, K.; Fukuda, R.; Hasegawa, J.; Ishida, M.; Nakajima, T.; Honda, Y.; Kitao, O.; Nakai, H.; Vreven, T.; J. A. Montgomery, J.; Peralta, J. E.; Ogliaro, F.; Bearpark, M.; Heyd, J. J.; Brothers, E.; Kudin, K. N.; Staroverov, V. N.; Keith, T.; Kobayashi, R.; Normand, J.; Raghavachari, K.; Rendell, A.; Burant, J. C.; lyengar, S. S.; Tomasi, J.; Cossi, M.; Rega, N.; Millam, J. M.; Klene, M.; Knox, J. E.; Cross, J. B.; Bakken, V.; Adamo, C.; Jaramillo, J.; Gomperts, R.; Stratmann, R. E.; Yazyev, O.; Austin, A. J.; Cammi, R.; Pomelli, C.; Ochterski, J. W.; Martin, R. L.; Morokuma, K.; Zakrzewski, V. G.; Voth, G. A.; Salvador, P.; Dannenberg, J. J.; Dapprich, S.; Daniels, A. D.; Farkas, O.; Foresman, J. B.; Ortiz, J. V.; Cioslowski, J.; Fox, D. J.; Gaussian Inc., Wallingford, CT, 2013.

S31 Becke, A. D. Density-functional exchange-energy approximation with correct asymptotic behavior. Phys. Rev. A 1988, 38, 3098.

S32 Perdew, J. P. Density-functional approximation for the correlation energy of the inhomogeneous electron gas. Phys. Rev. B 1986, 33, 8822.

S33 Andrae, D.; Haussermann, U.; Dolg, M.; Stoll, H.; Preuss, H. Energy-adjusted ab initio pseudopotentials for the second and third row transition elements. Theor. Chim. Acta 1990, 77, 123.

S34 Hollwarth, A.; Bohme, M.; Dapprich, S.; Ehlers, A. W.; Gobbi, A.; Jonas, V.; Kohler, K. F.; Stegmann, R.; Veldkamp, A.; Frenking, G. A set of d-polarization functions for pseudo-potential basis sets of the main group elements $\mathrm{Al} \cdot \mathrm{Bi}$ and f-type polarization functions for Zn, Cd, Hg. Chem. Phys. Lett. 1993, 208, 237.

S35 Hehre, W. J.; Ditchfield, R.; Pople, J. A. Self-Consistent Molecular Orbital Methods. XII. Further Extensions of Gaussian-Type Basis Sets for Use in Molecular Orbital Studies of Organic Molecules. J. Chem. Phys. 1972, 56, 2257.

S36 Hariharan, P. C.; Pople, J. A. The influence of polarization functions on molecular orbital hydrogenation energies. Theor. Chim. Acta 1973, 28, 213.

S37 Bader, R. F. W. Atoms in Molecules: A Quantum Theory; Oxford University Press, 1990.

S38 AIMAll (Version 17.11.14), Todd A. Keith, TK Gristmill Software, Overland Park KS, USA, 2017 (aim.tkgristmill.com)

S39 NBO 6.0. E. D. Glendening, J. K. Badenhoop, A. E. Reed, J. E. Carpenter, J. A. Bohmann, C. M. Morales, C. R. Landis, and F. Weinhold (Theoretical Chemistry Institute, University of Wisconsin, Madison, WI, 2013); http://nbo6.chem.wisc.edu/

S40 Johnson E. R.; Keinan S.; Mori-Sanchez P.; Contreras-Garcia J.; Cohen A. J.; Yang W. Revealing Noncovalent Interactions. J. Am. Chem. Soc. 2010, 132, 6498.

S41 Contreras-Garcia J.; Johnson E. R.; Keinan S.; Chaudret R.; Piquemal J-P.; Beratan D. N.; Yang W. NCIPLOT: A Program for Plotting Noncovalent Interaction Regions. J. Chem. Theory Comput. 2011, 7, 625. 
S42 Chemcraft - graphical software for visualization of quantum chemistry computations. https://www.chemcraftprog.com

S43 Pickard, C. J.; Mauri, F. All-electron magnetic response with pseudopotentials: NMR chemical shifts. Phys. Rev. B 2001, 63, 245101.

S44 Yates, J. R.; Pickard, C. J.; Mauri, F. Calculation of NMR chemical shifts for extended systems using ultrasoft pseudopotentials. Phys. Rev. B 2007, 76, 024401.

S45 Clark, S. J.; Segall, M. D.; Pickard, C. J.; Hasnip, P. J.; Probert, M. J.; Refson, K.; Payne, M. C. First principles methods using CASTEP. Z. Kristallogr. 2005, 220, 567.

S46 Monkhorst, H. J.; Pack, J. D. Special points for Brillouin-zone integrations. Phys. Rev. B 1976, 13, 5188.

S47 van Lenthe, E.; Baerends, E. J.; Snijders, J. G. Relativistic regular two-component Hamiltonians. J. Chem. Phys. 1993, 99, 4597.

S48 van Lenthe, E.; Baerends, E. J.; Snijders, J. G. Relativistic total energy using regular approximations. J. Chem. Phys. 1994, 101, 9783.

S49 Lodewyk, M. W.; Siebert, M. R.; Tantillo, D. Computational Prediction of ${ }^{1} \mathrm{H}$ and ${ }^{13} \mathrm{C}$ Chemical Shifts: A Useful Tool for Natural Product, Mechanistic, and Synthetic Organic Chemistry. J. Chem. Rev. 2012, 112, 1839.

S50 C. F.; Bruno, I. J.; Chisholm, J. A.; Edgington, P. R.; $\quad$ McCabe, P.; Pidcock, E.; Rodriguez-Monge, L.; Taylor, R.; van de Streek, J.; Wood, P. A. Mercury CSD 2.0 new features for the visualization and investigation of crystal structures. J. Appl. Cryst., 2008, 41, 466. 